\title{
DEGRADABILIDADE DE EMBALAGENS COMPOSTAS DE LAMINADOS DE PAPEL REVESTIDO, PLÁSTICO E ALUMÍNIO E SUA INTERAÇÃO COM O MEIO AMBIENTE
}

\author{
MARA LÚCIA SIQUEIRA DANTAS
}

Química Industrial

Orientador: Prof. Dr. JOSÉ MANGOLINI NEVES

\begin{abstract}
Dissertação apresentada à Escola Superior de Agricultura "Luíz de Queiroz", Universidade de São Paulo, para obtenção do título de mestre em Ciências, Área de Concentração: Ciência e Tecnologia de Madeiras.
\end{abstract}

PIR A C I C A B A

Estado de São Paulo - Brasil

Fevereiro -2000 


\title{
Dados Internacionais de Catalogação na Publicação (CIP) DIVISÃO DE BIBLIOTECA E DOCUMENTAÇÃO - Campus "Luiz de Queiroz"/USP
}

\author{
Dantas, Mara Lúcia Siqueira \\ Degradabilidade de embalagens compostas de laminados de papel revestido, plástico e \\ aluminio e sua interação com meio ambiente / Mara Lúcia Siqueira Dantas. - - Piracicaba, \\ 2000. \\ 194 p. : il.
}

Dissertação (mestrado) - Escola Superior de Agricultura Luiz de Queiroz, 2000.

Bibliografia.

1. Degradação 2. Embalagem de papel 3. Impacto ambiental 4. Papel-cartão 5. Reciclagem 6. Tecnologia de celulose e papel I. Título

CDD 676.32 
à minha familia 


\section{AGRADECIMENTOS}

ao meu orientador, por sua extrema atenção e constante apoio durante todo andamento do trabalho;

ao corpo docente do curso de Ciência e Tecnologia de Madeiras da ESALQ, do PROCAM, da FEA e da EPUSP, onde obtive os conhecimentos para alcançar a formação necessária para a elaboração deste trabalho;

ao Pesquisador Físico, Mestre Rogério Parra, pelo incentivo constante e valiosa colaboração;

ao IPT, por ter cedido parte de meu tempo para que eu me dedicasse a este trabalho, em especial ao Pesquisador Ernesto F. Pichler (Lab. de Embalagem) pelas críticas construtivas e cessão de equipamentos para os ensaios de degradação ao calor e imersão em chorume, ao Pesquisador Eraldo Maluf (LPTEX) pela cessão do equipamento de iluminação U.V., colorímetro e pelo conhecimento transmitido sobre avaliação de cor, ao Pesquisador José Marcio Carter (Laboratório de Biotecnologia) pelo apoio nas análises bioquímicas e químicas, às Pesquisadoras Selma Barbosa Jaconis e Evelyne Yvonne L. Vaidergorin (Lab. de Plásticos e Borrachas) pela cessão dos equipamentos de espectrofotometria no infravermelho e dinamômetro universal de ensaios e valiosa colaboração na execução e interpretação dos resultados, ao Técnico de Laboratório Luiz Carlos do Carmo Lindo (Lab. de Plásticos e Borrachas) pela ajuda na execução dos ensaios, às Pesquisadoras Shoko Ota e Sônia I. Deróbio (CaQui) na cessão do equipamento de espectrofotometria no infravermelho e ajuda nas técnicas analíticas, às Pesquisadoras Regina Coeli Testa Takahashi, Marisa Eiko Tsukuda Koga e Maria Luiza D'Almeida Otero (Laboratório de Celulose e Papel) pela cessão de equipamentos de análise de papel, críticas construtivas e colaboração na pesquisa bibliográfica, ao Técnico de Laboratório Antonio dos Santos Filho (Celulose e Papel) pelas instruçōes na 
execução dos ensaios, ao Técnico de Laboratório Luiz (Laboratório de Corrosão) pela valiosa contribuição na documentação fotográfica, ao Pesquisador Neusvaldo Lira de Almeida (Laboratório de Corrosão) pela cessão de espaço na estação de corrosão atmosférica, aos estagiários-aluno Fernanda, José, Danilo, Jefferson e Marcel (Laboratório de Embalagem) pela ajuda na execução de algumas tarefas árduas, como por exemplo a coleta do chorume.

ao IAG, em especial ao Prof. Dr. Ricardo Camargo por ter levantado os dados meteorológicos do período de exposição das amostras;

ao meus pais pela semente que plantaram, da busca pelo saber e a minha filha Helena pela paciência;

aos colaboradores de amostras para a realização do trabalho (Prof. Dr. Márcio Nahuz, Creche do IPT e Parmalat); 


\section{SUMÁRIO}

PÁGINA

1 INTRODUÇÃO

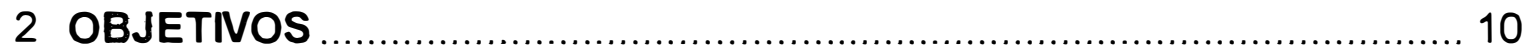

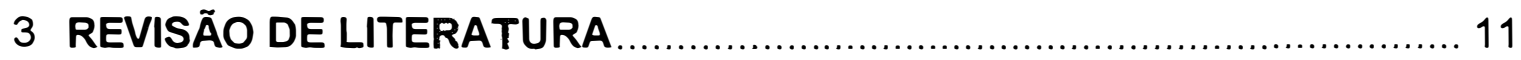

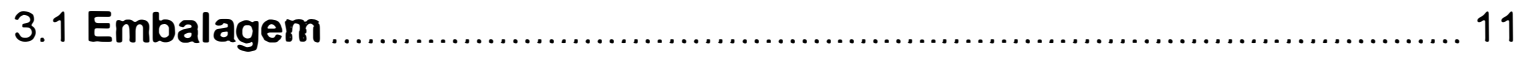

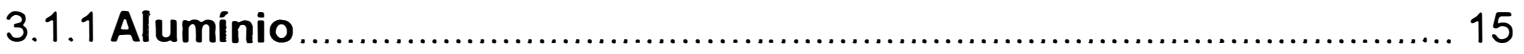

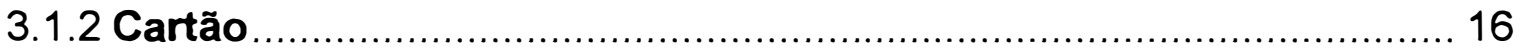

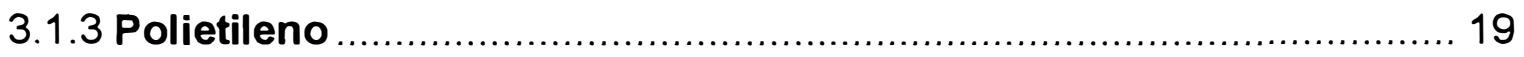

3.2 Revestimentos e Laminação de Materiais Celulósicos …................... 23

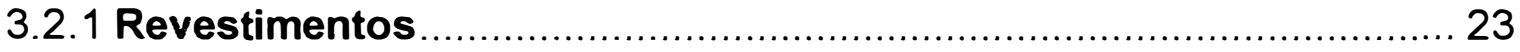

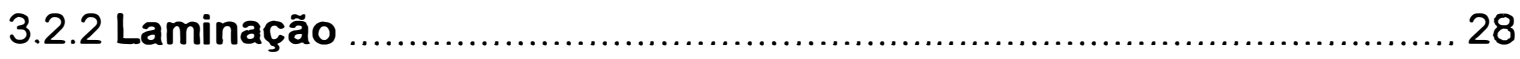

3.3 Formação de Embalagens Cartonadas …........................................ 30

3.4 Permeabilidade de Materiais Laminados ........................................ 36

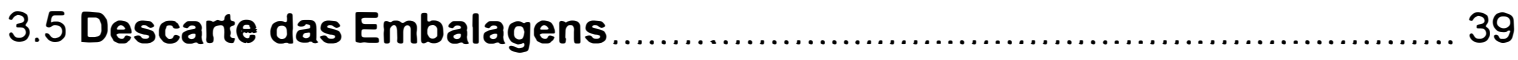

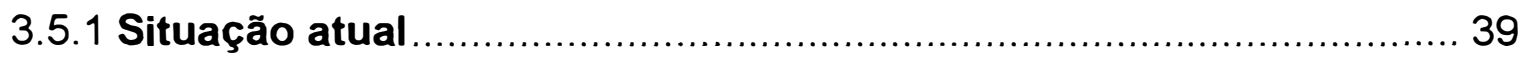

3.5.2 "Lixão", aterro controlado e aterro sanitário ............................... 52

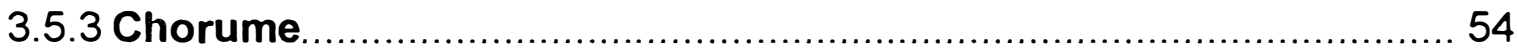

3.5.4 Resíduos sólidos no aterro sanitário .............................................. 55

3.5.5 Degradação dos materiais de embalagem .................................. 57

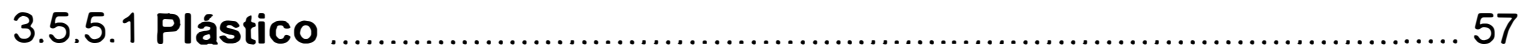

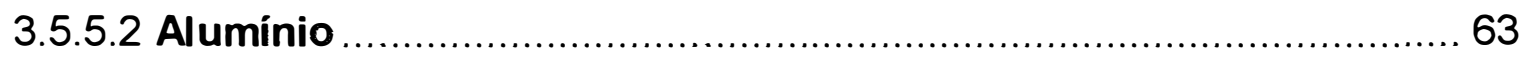

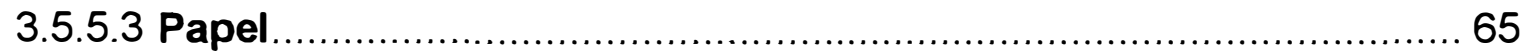

3.5.6 Estudos de degradabilidade de materiais ..................................67

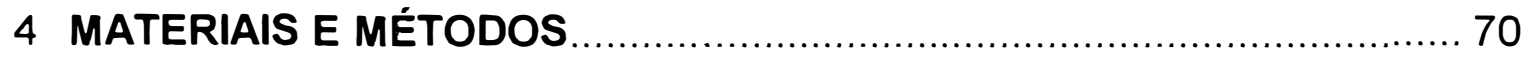

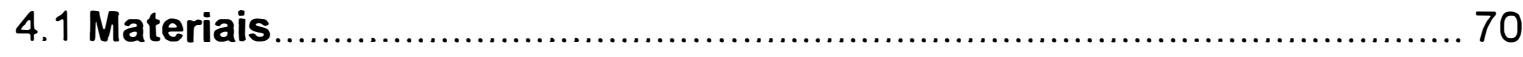

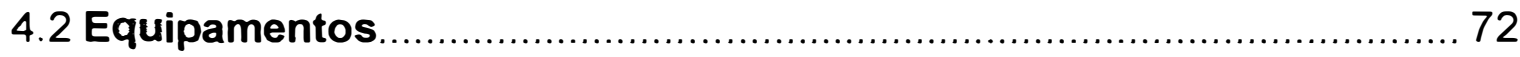

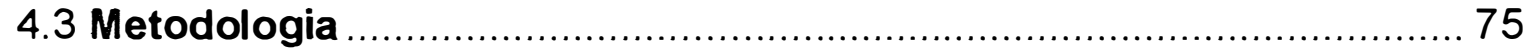


4.3.1 Caracterização e análises periódicas dos materiais ...................... 75

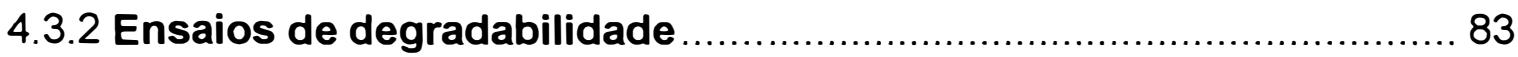

5 RESULTADOS

5.1 Caracterização das Embalagens Multicamadas ................................ 87

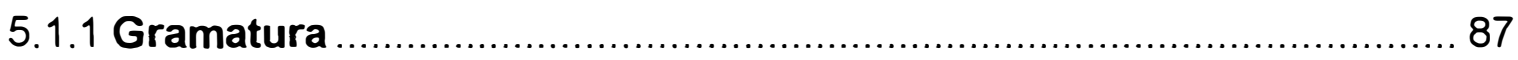

5.1.2 Rigidez Lhomargy e módulo de elasticidade na direção " $Z$ " ........... 88

5.1.3 Tensão de ruptura, módulo de elasticidade e alongamento

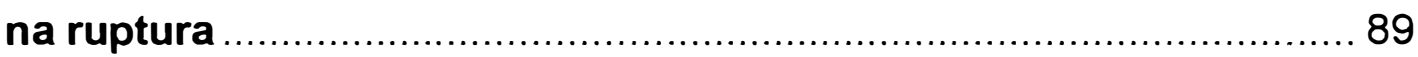

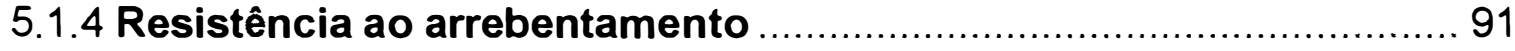

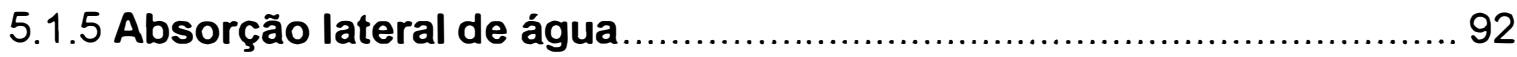

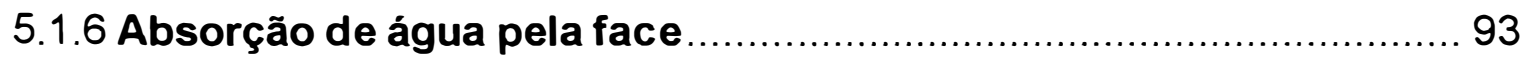

5.1.7 Absorção de água da embalagem inteira ....................................... 93

5.1.8 Identificação das camadas plásticas............................................. 94

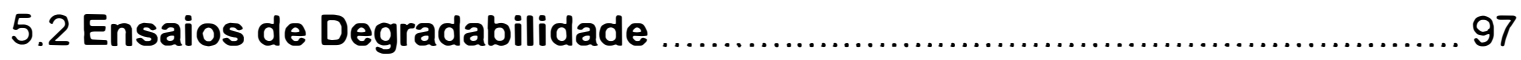

5.2.1 Degradabilidade por imersão em chorume …............................. 97

5.2.2 Degradabilidade por exposição à luz ultravioleta ......................... 107

5.2.3 Degradabilidade por exposição às intempéries .......................... 113

5.2.4 Degradabilidade por ação do calor............................................ 118

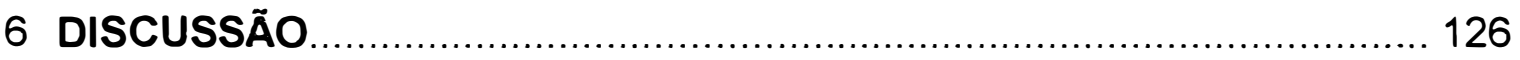

6.1 Caracterização das Embalagens Multicamadas ............................... 126

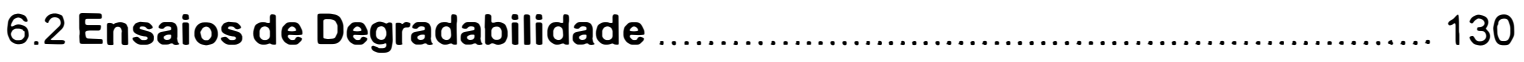

6.2.1 Degradabilidade por imersão em chorume ................................ 130

6.2.2 Degradabilidade por exposição à luz ultravioleta ......................... 137

6.2.3 Degradabilidade por exposição às intempéries ........................... 146

6.2.4 Degradabilidade por ação do calor .......................................... 158

6.3 Análise Integrada dos Ensaios de Degradabilidade ....................... 166

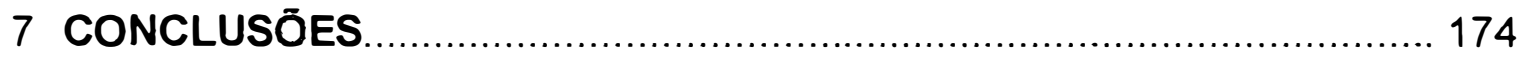

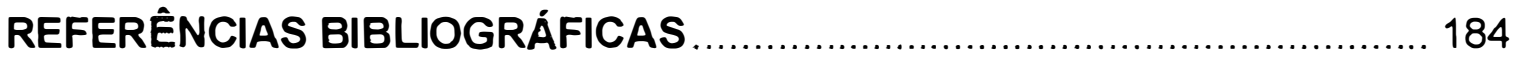




\section{LISTA DE FIGURAS}

PÁGINA

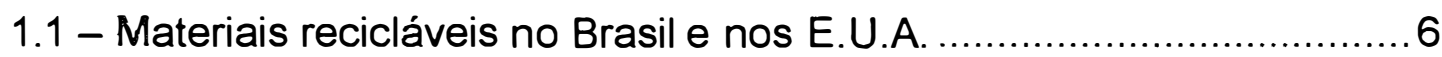

1.2 - Destinação final do lixo em diversos países e regiões - 1991 ............ 8

3.1 - Esquema do sistema Tetra Brick................................................... 31

3.2 - Termossoldagem longitudinal da International Paper ........................ 32

3.3 - Esquema do sistema Combibloc ................................................... 35

3.4 - Formato da embalagem produzida pelo sistema Liquipak ................. 35

3.5 - Diagrama para mostrar como ocorre a absorção na área de

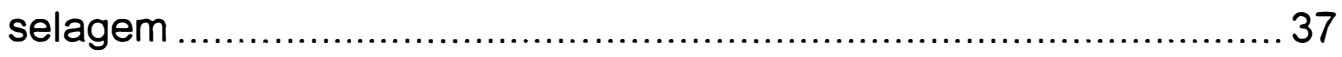

3.6 - Composição dos resíduos (\% em peso), em diversos países ............. 39

3.7 - Composição do lixo no Brasil .......................................................... 41

3.8 - Composição do lixo no E.U.A.......................................................... 41

3.9 - Ordenação para o tratamento do resíduo sólido gerado pelas

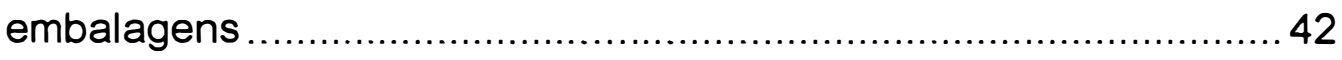

3.10 - Processo de reciclagem de embalagens Tetra Pak ....................... 49

3.11 - Espectro de polietileno exposto à degradação em composto

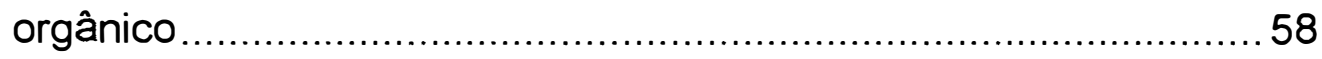

4.1 - Representação gráfica dos termos psicométricos do Sistema

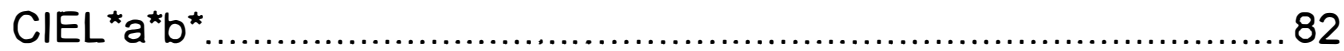

5.1 - Espectro de polietileno retirado da bibliografia..................................94

5.2 - Camada externa da amostra de leite - polietileno linear .................... 95

5.3 - Camada interna da amostra de leite - polietileno linear...................... 95

5.4 - Camada externa da amostra de suco -polietileno linear..................... 96

5.5 - Camada interna da amostra de suco - polietileno linear.................... 96

5.6 - Camada externa da amostra de leite após seis meses de imersão no chorume - polietileno oxidado ................................. 105

5.7 - Camada interna da amostra de leite após seis meses de imersão no chorume - polietileno oxidado ................................ 105 
5.8 - Camada externa da amostra de suco após seis meses de imersão no chorume - polietileno oxidado ................................. 106

5.9 - Camada interna da amostra de suco após seis meses de imersão no chorume - polietileno oxidado ............................... 106

5.10 - Camada externa da amostra de suco após 200h de exposição em u.v. - polietileno oxidado

5.11 - Camada externa da amostra de leite após $200 \mathrm{~h}$ de exposição em u.v.- polietileno

5.12 - Camada externa da amostra de leite após seis meses de exposição às intempéries - polietileno oxidado.

5.13 - Camada externa da amostra de suco após cinco meses de exposição às intempéries - polietileno oxidado.

5.14 - Camada externa da amostra de leite após seis meses de envelhecimento na estufa - polietileno oxidado

5.15 - Camada externa da amostra de suco após seis meses de envelhecimento na estufa - polietileno oxidado

5.16 - Camada interna da amostra de leite após seis meses de envelhecimento na estufa - polietileno oxidado

5.17 - Camada interna da amostra de suco após seis meses de envelhecimento na estufa - polietileno oxidado

6.1 - Variação de massa de ambas as amostras na condição úmida e seca

6.2 - Tensão de ruptura das amostras de suco envelhecidas no chorume . 133

6.3 - Tensão de ruptura das amostras de leite envelhecidas no chorume .. 134

6.4 - Espessura da amostra de leite após imersão no chorume.

6.5 - Camada externa da amostra de leite com um mês de imersão no chorume - polietileno oxidado

6.6 - Estimativa de perda de cor para ambas as amostras após exposição a luz ultravioleta com condensação. 
6.7 - Rigidez Lhomargy das amostras de suco envelhecidas na luz ultravioleta.

6.8 - Módulo de elasticidade na direção " $Z$ " das amostras de suco envelhecidas na luz ultravioleta.

6.9 - Rigidez Lhomargy das amostras de leite envelhecidas na luz ultravioleta

6.10 - Módulo de elasticidade na direção " $Z$ " das amostras de leite envelhecidas na luz ultravioleta

6.11 - Tensão de ruptura das amostras de suco envelhecidas na luz ultravioleta

6.12 - Módulo de elasticidade das amostras de suco envelhecidas na luz ultravioleta.

6.13 - Alongamento na ruptura das amostras de suco envelhecidas na luz ultravioleta.

6.14 - Tensão de ruptura das amostras de leite envelhecidas na luz ultravioleta.

6.15 - Módulo de elasticidade das amostras de leite envelhecidas na luz ultravioleta

6.16 - Alongamento na ruptura das amostras de leite envelhecidas na luz ultravioleta.

6.17 - Gramatura em função do tempo de ambas as amostras no envelhecimento de intemperismo natural

6.18 - Módulo de elasticidade na direção " $Z$ " das amostras de suco envelhecidas no intemperismo natural.

6.19 - Rigidez Lhomargy das amostras de suco envelhecidas no intemperismo natural

6.20 - Espessura das amostras de suco após envelhecimento no intemperismo natural

6.21 - Rigidez Lhomargy das amostras de leite envelhecidas no intemperismo natural 
6.22 - Módulo de elasticidade na direção " $Z$ " das amostras

de leite envelhecidas no intemperismo natural.

6.23 - Tensão de ruptura das amostras de suco envelhecidas no intemperismo natural 154

6.24 - Módulo de elasticidade das amostras de suco envelhecidas no intemperismo natural

6.25 - Alongamento na ruptura das amostras de suco envelhecidas no intemperismo natural

6.26 - Tensão de ruptura das amostras de leite envelhecidas no intemperismo natural

6.27 - Módulo de elasticidade das amostras de leite envelhecidas no intemperismo natural

6.28 - Alongamento na ruptura das amostras de leite envelhecidas no intemperismo natural

6.29 - Rigidez Lhomargy das amostras de suco envelhecidas na estufa ... 159

6.30 - Módulo de elasticidade na direção "Z" das amostras de suco envelhecidas na estufa 160

6.31 - 'Rigidez Lhomargy das amostras de leite envelhecidas na estufa..... 161

6.32 - Módulo de elasticidade na direção " $Z$ " das amostras de leite envelhecidas na estufa

6.33 - Tensão de ruptura das amostras de leite envelhecidas na estufa..... 162

6.34 - Módulo de elasticidade das amostras de leite envelhecidas na estufa.

6.35 - Alongamento na ruptura das amostras de leite envelhecidas na estufa. 164

6.36 - Tensão de ruptura das amostras de suco envelhecidas na estufa.... 165

6.37 - Módulo de elasticidade das amostras de suco envelhecidas na estufa. 165

6.38 - Alongamento na ruptura das amostras de suco envelhecidas na estufa. 166 
6.39 - Perda da resistência à tração em função do tempo na degradação por imersão no chorume

6.40 - Perda da resistência à tração em função do tempo na degradação por ultravioleta

6.41 - Perda da resistência à tração em função do tempo na degradação por intempéries

6.42 - Perda da resistência à tração em função do tempo na degradação pelo calor

6.43 - Camada externa da amostra de leite após seis meses de envelhecimento na estufa - polietileno oxidado

6.44 - Camada externa da amostra de leite após seis meses de imersão no chorume - polietileno oxidado

6.45 - Camada externa da amostra de suco após seis meses de envelhecimento na estufa - polietileno oxidado

6.46 - Camada externa da amostra de suco após seis meses de imersão no chorume - polietileno oxidado

6.47 - Camada externa da amostra de leite após 200h de exposição em u.v.- polietileno

6.48 - Camada externa da amostra de leite após seis meses de exposição às intempéries - polietileno oxidado.

6.49 - Camada externa da amostra de suco após 200h de exposição em u.v. - polietileno oxidado

6.50 - Camada externa da amostra de suco após cinco meses de exposição às intempéries - polietileno oxidado 


\section{LISTA DE TABELAS}

PÁGINA

1.1 - Mercado de embalagens brasileiro 1988-20003 ............................... 3

1.2 - Mercado de embalagens brasileiro em 1993, por uso....................... 3

1.3 - Evolução do mercado de embalagens brasileiro ............................... 4

1.4 - Evolução do mercado de embalagens de papel brasileiro ................. 4

3.1 - Principais características de alguns substratos usados em

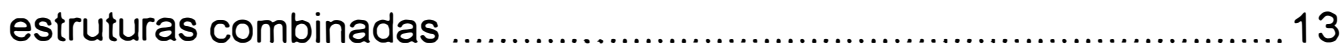

3.2 - Exemplos de estruturas colaminadas e suas aplicações .................. 14

3.3 - Valores típicos de cartões nacionais .......................................... 17

3.4 - Características de cartões utilizados em embalagens de

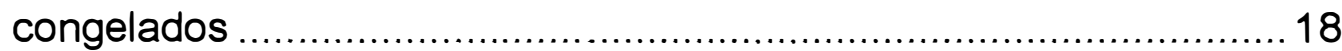

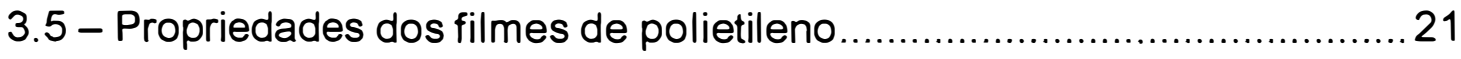

3.6 - Evolução histórica da composição (\% em massa total) dos resíduos sólidos gerados no município de São Paulo entre 1927 e 1993

3.7 - Brasil - Número de municípios que praticam a coleta seletiva, segundo extratos populacionais selecionados - 1994

3.8 - Brasil - Composição média dos resíduos sólidos observada em programas de coleta seletiva promovidos por cidades selecionadas 1992-1994. 44

3.9 - Brasil - Nivel de reciclagem alcançado........................................... 44

3.10 - Países selecionados - A reciclagem do papel em 1990 ................ 46

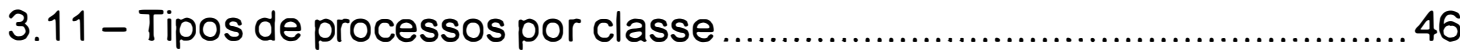

3.12 - Processamento/reciclagem física de laminados com alumínio .........44 47

3.13 - Processamento/ reciclagem química de laminados com alumínio .... 47

3.14 - Processamento/reciclagem físico-química de laminados com

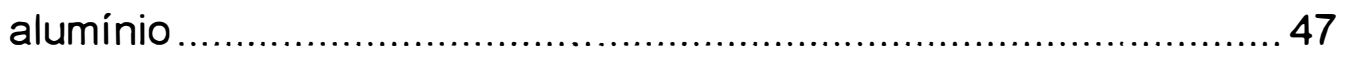

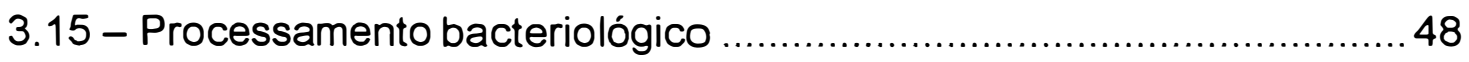


3.16 - Brasil - Consumo de aparas para produção de papel em 1995 ........50

3.17 - Mercado de leite no Brasil em 1996 ............................................. 52

3.18 - Evolução do consumo de embalagens "caixinhas" em

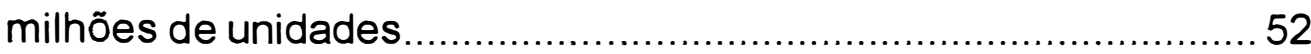

3.19 - Suscetibilidade dos plásticos às intempéries ................................. 62

3.20 - Métodos de biodegradabilidade de plásticos ................................68

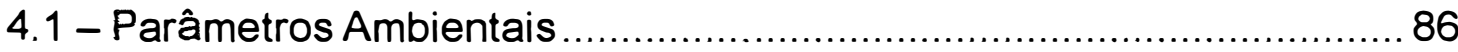

5.1 - Resultados de gramatura dos materiais multicamada...................... 88

5.2 - Resultados do ensaio de rigidez Lhomargy - amostra original -

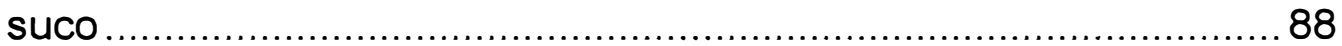

5.3 - Resultados do ensaio de rigidez Lhomargy - amostra original -

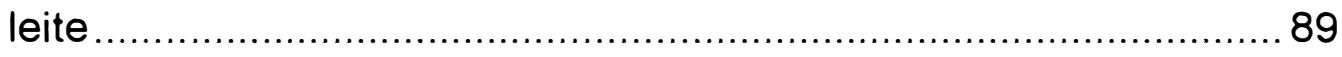

5.4 - Resultados preliminares do ensaio de tração da estrutura ................90

5.5 - Resultados do ensaio de tração - amostra original - suco ................. 91

5.6 - Resultados do ensaio de tração - amostra original - leite ................. 91

5.7 - Resultados do ensaio de arrebentamento......................................92

5.8 - Resultados do ensaio de absorção lateral da amostra de leite ........... 92

5.9 - Resultados do ensaio de absorção lateral da amostra de suco ..........93

5.10 - Absorção de água da embalagem inteira.................................... 93

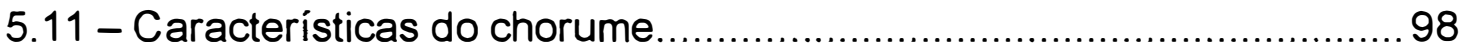

5.12 - Determinações de temperatura e pH para o controle do banho........98

5.13 - Variação de massa da amostra de suco .......................................... 100

5.14 - Variação de massa da amostra de leite ......................................... 100

5.15 - Resultados do ensaio de tração - amostra envelhecida por imersão no chorume - Suco ...................................................... 103

5.16 - Resultados do ensaio de tração - amostra envelhecida por imersão no chorume - Leite 103

5.17 - Resultados do ensaio de tração - amostra envelhecida por imersão no chorume - Leite 
5.18 - Estimativa de perda de cor representada por $D E^{\star}$ de ambas as amostras 107

5.19 - Gramatura das amostras após exposição à luz ultravioleta 109

5.20 - Resultados do ensaio de rigidez Lhomargy - amostra envelhecida na luz ultravioleta - Leite 109

5.21 - Resultados do ensaio de rigidez Lhomargy - amostra envelhecida na luz ultravioleta - Suco.

5.22 - Resultados do ensaio de tração - amostra envelhecida na luz ultravioleta - Suco.

5.23 - Resultados do ensaio de tração - amostra envelhecida na luz ultravioleta - Leite

5.24 - Gramatura das amostras após intemperismo natural

5.25 - Resultados do ensaio de rigidez Lhomargy - amostra envelhecida no intemperismo natural - Leite

5.26 - Resultados do ensaio de rigidez Lhomargy - amostra envelhecida no intemperismo natural - Suco

5.27 - Resultados do ensaio de tração - amostra envelhecida no intemperismo natural - Suco

5.28 - Resultados do ensaio de tração - amostra envelhecida no intemperismo natural - Leite.

5.29 - Gramatura das amostras após envelhecimento na estufa

5.30 - Resultados do ensaio de rigidez Lhomargy - amostra envelhecida na estufa - Suco

5.31 - Resultados do ensaio de rigidez Lhomargy - amostra envelhecida na estufa - Leite

5.32 - Resultados do ensaio de tração - amostra envelhecida na estufa - Suco. 
5.33 - Resultados do ensaio de tração - amostra envelhecida na estufa Leite.

6.1 - Degradação das embalagens multicamadas com base na perda de resistência e massa

7.1 - Estimativa de vida média dos componentes das embalagens em ambiente crítico do aterro......

7.2 - Estimativa de vida média dos componentes das embalagens no intemperismo natural 


\section{LISTA DE SIGLAS, ABREVIATURAS E SIMBOLOS}

( ) - marca registrada

E.U.A. - Estados Unidos da América

PVC - poli (-cloreto de vinila-)

EVOH - etileno vinil álcool

PET - poli (- etileno tereftalato-)

ISO - International Standard Organization

ASTM - American Standards Testing Materials

U.R. - umidade relativa

EVA - acetato de vinila

TAPPI - Technical Association of the Pulp and Paper Industry

NBR - Norma Brasileira

TPVA - taxa de permeabilidade ao vapor d'água

Al-alumínio

PE - polietileno 


\title{
DEGRADABILIDADE DE EMBALAGENS COMPOSTAS DE LAMINADOS DE PAPEL REVESTIDO, PLÁSTICO E ALUMÍNIO E SUA INTERAÇÃO COM O MEIO AMBIENTE
}

\author{
Autor : MARA LÚCIA SIQUEIRA DANTAS \\ Orientador : Prof. Dr. JOSÉ MANGOLINI NEVES
}

\section{RESUMO}

É crescente o impacto negativo gerado sobre o ambiente pelo descarte de embalagens feitas com diferentes materiais combinados e com alta resistência a úmido. As propostas de solução, sejam elas através da reciclagem ou da incineração, estão ainda em uma fase piloto ou insipiente.

Neste trabalho aplicaram-se metodologias que buscavam simular as condições de degradação aeróbicas e anaeróbicas encontradas nas diversas formas de disposição do resíduo sólido para dois tipos de embalagens multicamadas (compósito). As metodologias empregadas foram desenvolvidas e avaliadas. Comparou-se a suscetibilidade à degradação destes dois tipos de embalagem, procurando correlacionar suas características físico-químicas com os mecanismos de degradação ocorridos.

Para simular algumas das condições encontradas nos lixões, adaptou-se uma metodologia de ensaio de exposição às intempéries que mostrou, de forma comparativa, a facilidade de materiais compósitos se degradarem no ambiente. Como tentativa de avaliar esta metodologia com uma possivel correspondência de um ensaio acelerado, optou-se pela exposição das amostras numa câmara com ciclos alternados de radiação ultravioleta e condensação de água em temperatura controlada.

Para avaliar a degradabilidade das embalagens em aterro sanitário adotou-se como critério a condição mais crítica, através da imersão das embalagens no chorume na temperatura de $50^{\circ} \mathrm{C}$. Paralelamente, isolou-se 
o efeito do calor na degradação por exposição das amostras na mesma temperatura e submetendo-as às mesmas determinações das amostras imersas no chorume.

Ambos os métodos mostraram sensibilidade para distingüir as diferenças de suscetibilidade à degradação das amostras através da velocidade com esta que ocorreu em de cada amostra. Além disso, este métodos apresentaram coerência dos dados nos ensaios de acompanhamento, pois a degradação foi crescente com o tempo de exposição. Para a degradação em intempéries naturais e imersão no chorume, a reprodutibilidade é prejudicada pois em ambos casos existe a dificuldade de controlar o meio (chorume ou intemperismo), mas pôde-se correlacionar as características medidas destes meios com alterações das amostras.

Quanto à desintegração das embalagens, observou-se que a embalagem composta por polietileno/cartão dupléx/alumínio (1) degradou-se mais que a embalagem composta por polietileno/cartão branco (2). Em seis meses, a perda de massa da amostra 1 foi de $49 \%$ de sua massa inicial no ensaio de degradação por imersão no chorume e de $21 \%$ em exposição às intempéries, enquanto que a amostra 2 apresentou ganho de massa (chorume) e não se alterou (intempéries) no mesmo período.

A perda de massa foi devida majoritariamente à degradação do cartão em ambos ensaios de degradação. O cartão duplex degradou mais que o cartão branco, provavelmente, porque a lignina nele presente seja removida na condição alcalina do ensaio de imersão no chorume e mais suscetivel à ação do ultravioleta do que a celulose. Enquanto que o cartão branco seja, talvez, aditivado com resinas insolúveis que impeçam a ação do chorume e da água (chuvas).

Por fim, pôde-se ainda formular recomendações tanto ao projeto como ao manuseio de embalagens descartáveis: cuidados nas bordas e nas linhas de soldagem e sugestões para melhoria da resistência do cartão da embalagem (1) através de tratamento térmico. 


\title{
DEGRADABILITY OF COATED PAPER, PLASTIC AND ALUMINIUM LAMINATED COMPOSITE PACKAGES AND ITS INTERACTION WITH THE ENVIRONMENT
}

\author{
Author: MARA LÚCIA SIQUEIRA DANTAS \\ Adviser : Prof. Dr. JOSÉ MANGOLINI NEVES
}

\section{ABSTRACT}

An increasing negative impact is happening due to the disposal into the environment of high humidity resistant packages made up of combined different materials. At present, the proposed solutions (recycling and incineration) are in very primary stages.

In this thesis, methodologies that simulate the aerobic and anaerobic degradation conditions found in the solid waste disposal were applied in two kinds of laminated (composite) packaging. So, the proper methodologies could be developed and evaluated. The degradation susceptibilities of these two materials were compared and the probable correlation between their characteristic properties and the observed degradation mechanisms was estimated.

To simulate some conditions found in the open sky disposal, a methodology of a weather exposition test was adapted. This test showed comparatively the tendency of those composite materials to degrade in the natural environment. An alternative methodology was developed to be assigned as an accelerated test of these conditions. The samples were exposed to ultraviolet radiation and water condensation inside a chamber with controlled temperature.

To simulate the degradation within an soil burial, the criterion was the most critical conditions that could be found in that ambient. The 
packages were immerged in the soil burial leachate and kept at $50^{\circ} \mathrm{C}$. Meanwhile, the temperature effect on degradation could be evaluated alone. Some samples were put in a dry woven and submitted to the same tests that are applied to the ones immerged in the leachate.

The packaging composed by polyethylene / carton / aluminium (\#1) was more degraded than the one made up of polyethylene / white carton (\#2). In the first six months, the \#1 sample lost $49 \%$ of its initial mass in the leachate immersion and $21 \%$ of its mass during the weather exposure. The initial mass of the \#2 sample had increased in the leachate and had not showed any alteration due to weather by the same time of exposition.

The carton degradation was the major cause of mass losses in both tests. The duplex carton had more susceptibility to degrade than the whitened one, probably because of the lignin in the duplex carton can be removed by the alkaline conditions of the leachate immersion test and be more sensitive to the ultraviolet radiation that the cellulose. The whitened carton may have insoluble resins as additives that protect it from the leachate and from the rain waters.

Finally, some recommendations to the design and handling of these packages could be formulated about some care to the borders and seams to avoid microorganisms getting in and suggestions to improve the mechanical resistance of the carton by means of a thermal treatment. 


\section{INTRODUÇÃO}

Uma embalagem tem como principais funções conter o produto, protegê-lo durante o transporte, movimentação e armazenagem, reduzindo riscos de contaminação por impurezas, insetos, bactérias, evitando a penetração de umidade ou oxigênio e ser atrativa aos consumidores, ou seja, deve vender 0 produto. Além destas funções, há também 0 dever perante 0 consumidor de informá-lo, protegê-lo e, em certos casos, garantir que o seu conteúdo, nem a própria embalagem, quando descartada, não agridam o meio ambiente.

$\mathrm{Na}$ busca de atender todas essas funções, a um custo adequado, e que resulte num produto competitivo, cresce cada vez mais a utilização de materiais combinados. De um modo geral, os materiais utilizados em embalagens são: papel, papelão ondulado, cartão, madeira, plásticos, metais (aluminio e aço) e vidro. Esses materiais podem ser combinados de diversas maneiras e formas a fim de se obter uma embalagem de boa qualidade e com um custo agregado competitivo'.

Produzir embalagens com um só material facilita sua reciclagem, o que implica em benefício direto ao meio ambiente devido à facilidade de coleta e tratamento além de muitas vezes representar um menor volume descartado. Entretanto, por diversas razões, ligadas freqüentemente às

\footnotetext{
${ }^{1}$ O custo agregado compreende não só o custo da matéria-prima, mas os custos do processo de fabricação, do transporte do produto acabado e do armazenamento.
} 
condições de uso ou propriedades intrínsecas do produto que se embala, esta alternativa muitas vezes é rejeitada ou impossibilitada.

A literatura (Consumidor é quem dita...,1998) mostra que do total de 4,9 milhões de toneladas de embalagens produzidas pela indústria nacional em 1996, 61\% foram destinados ao setor alimentício, o restante, $31 \%$, foi para produtos não alimentícios, divididos nos setores de higiene e beleza, lazer e pessoal, limpeza, química e agricultura. Em termos monetários, estes percentuais corresponderam a valores de $62 \%$ para os produtos alimentícios e $38 \%$ para os demais. Vê-se que, o setor alimentício é um grande mercado para todas as indústrias que desenvolvam projetos e equipamentos voltados para a embalagem.

Dados sobre o mercado de embalagens no Brasil em 1994 (Crescimento recorde das embalagens plástica em 1994..., 1995) são apresentados nas Tabelas 1.1 e 1.2. Ressaltam-se a participação dos materiais celulósicos neste mercado segmentado por uso final no setor alimentício, representando $9 \%$ do total de toneladas comercializados pelo setor e $72 \%$ correspondendo ao setor não alimentício.

Entretanto, como estes valores percentuais foram calculados baseados no peso dos materiais, eles não refletem diretamente a participação dos materiais menos densos, tais como plásticos e papéis, que possuem uma participação muito maior no mercado. Já a Tabela 1.3 (Consumidor é quem dita..., 1998), mostra a evolução do mercado de embalagens por materiais considerando o valor monetário. Desta forma, podemos analisar melhor a participação econômica dos plásticos e dos papéis no setor de embalagens.

Mourad (1996) relata que a produção nacional de papel e celulose cresceu 5,2\% de 1994 para 1995 e a produção de papelão ondulado, considerando-se as caixas, acessórios e chapas, cresceu $4,45 \%$ no mesmo 
período. A evolução do mercado de papéis para embalagem é mostrada na Tabela 1.4 ( Projeto de expansão...;1998).

Mourad (1996) comenta também que nos EUA está previsto um aumento de $3,8 \%$ ao ano na capacidade de produção de diversos tipos de papelão (caixas, embalagens e ondulados), passando dos atuais 32,1 milhões de toneladas em 1994 para 37,3 milhões em 1998.

Tabela 1.1 - Mercado de embalagens brasileiro 1988-2000 (Crescimento,1995) ${ }^{2}$

\begin{tabular}{|c|c|c|c|c|c|c|c|c|c|c|}
\hline & & & & & & & & \multicolumn{3}{|c|}{ mil ton } \\
\hline & 1988 & 1989 & 1990 & 1991 & 1992 & 1993 & 1994 & $1995 p$ & $1996 p$ & $2000 p$ \\
\hline $\begin{array}{l}\text { Kraft } \\
\text { Papel Monolúcido } \\
\text { Duplex/Triplex }\end{array}$ & $\begin{array}{c}274 \\
36 \\
224\end{array}$ & $\begin{array}{c}251 \\
33 \\
279\end{array}$ & $\begin{array}{c}246 \\
43 \\
242\end{array}$ & $\begin{array}{c}236 \\
35 \\
244\end{array}$ & $\begin{array}{c}223 \\
36\end{array}$ & $\begin{array}{c}200 \\
35\end{array}$ & $\begin{array}{c}198 \\
33 \\
274\end{array}$ & $\begin{array}{c}201 \\
36 \\
275\end{array}$ & $\begin{array}{c}203 \\
38 \\
278\end{array}$ & $\begin{array}{c}215 \\
45 \\
295\end{array}$ \\
\hline Total papéis & 534 & 563 & 531 & 515 & 491 & 476 & 505 & 512 & 519 & 555 \\
\hline Caix & 907 & 104 & 915 & 102 & 978 & 1178 & 12 & 1262 & 1315 & 1528 \\
\hline Plást & 348 & 384 & 391 & 420 & 434 & 485 & 56 & 571 & 592 & 686 \\
\hline Flexiveis & 107 & 114 & 115 & 124 & 131 & 150 & 182 & 174 & 183 & 231 \\
\hline de-Flandres & 604 & 626 & 583 & 612 & 573 & 587 & 622 & 626 & 642 & 711 \\
\hline Alu & 13 & 15 & 19 & 21 & 20 & 27 & 47 & 49 & 51 & 61 \\
\hline$A c ̧ c$ & 151 & 149 & 143 & 125 & 121 & 118 & 126 & 130 & 134 & 147 \\
\hline Vidro & & & & & 717 & & & & & 1024 \\
\hline Total & 3490 & 3977 & 3628 & 3748 & 3464 & 3796 & 4140 & 4157 & 4306 & 4944 \\
\hline
\end{tabular}

Tabela 1.2 - Mercado de embalagens brasileiro em 1993, por uso (Crescimento, 1995)

\begin{tabular}{|c|c|c|c|c|c|}
\hline & Flexíveis & Metais & Papel & Plásticos & Vidro \\
\hline Bebidas & 15,24 & 122,04 & $\overline{14,94}$ & 109,70 & 625,83 \\
\hline Carnes e Vegetais & 12,79 & 119,65 & 5,20 & 54,98 & 47,42 \\
\hline Cereais e Farinhas & 20,67 & 13,32 & 54,57 & 78,63 & 5,47 \\
\hline Confeitaria e Doces & 24,17 & 29,12 & 31,48 & 37,97 & 27,70 \\
\hline Laticínios e Gorduras & 71,32 & 301,88 & 35,60 & 62,81 & 52,03 \\
\hline Alimentício & 144,19 & 586,01 & 141,80 & 344,09 & 758,45 \\
\hline Elétrico & --- & 7,84 & 9,67 & 2,95 & - \\
\hline Higiene e Beleza & 12,10 & 7,68 & 29,70 & 43,88 & 39,45 \\
\hline Lazer e Pessoal & 23,96 & - & 123,82 & 5,14 & 0,04 \\
\hline Limpeza Caseira & 0,47 & 18,89 & 80,28 & 59,11 & -- \\
\hline Química e Agricultura & 0,87 & 175,24 & 119,74 & 109,75 & 0,27 \\
\hline Não Alimentício & 37,40 & 209,64 & 363,22 & 220,84 & 39,76 \\
\hline Total & 181,58 & 795,66 & 505,02 & 564,93 & 798,21 \\
\hline
\end{tabular}

\footnotetext{
2 a letra " $\mathrm{p}^{\mathrm{n}}$ ao lado do ano indica previsão do autor do artigo em referência na época em que este foi escrito
} 
O mercado de embalagens celulósicas, em 1993 (Consumidor é quem dita... ,1998), representou cerca de $36 \%$ do valor total comercializado em materiais de embalagem.

Tabela 1.3 - Evolução do mercado de embalagens brasileiro (Consumidor, 1998) $)^{2}$

\begin{tabular}{l|c|c|c|c|c}
\multicolumn{1}{c}{} & \multicolumn{3}{c}{} & \multicolumn{2}{c}{ bilhões US\$ } \\
\cline { 2 - 5 } & 1993 & 1994 & 1995 & 1996 & $1997 p$ \\
\hline Plásticos & 1508 & 2021 & 2971 & 3286 & 3533 \\
Kraft & 626 & 795 & 648 & 699 & 736 \\
Papel Monolúcido & 49 & 43 & 62 & 67 & 69 \\
Caixas de Papelão & 1025 & 1554 & 1977 & 1608 & 1693 \\
Duplexe Triplex & 527 & 608 & 849 & 915 & 967 \\
Flexiveis & 918 & 1176 & 1568 & 1832 & 2052 \\
Aluminio & 195 & 266 & 553 & 621 & 641 \\
Folha-de-flandres & 763 & 822 & 1002 & 1117 & 1070 \\
Aço & 122 & 129 & 144 & 153 & 157 \\
Vidro & 465 & 560 & 648 & 582 & 625 \\
\hline Total & 6179 & 7976 & 10421 & 10779 & 11543 \\
\hline \hline
\end{tabular}

Tabela 1.4 - Evolução do mercado de embalagens de papel brasileiro (Projeto, 1998) $)^{2}$

\begin{tabular}{|c|c|c|c|c|c|}
\hline & & & & \multicolumn{2}{|c|}{ mil toneladas } \\
\hline & 1993 & 1994 & 1995 & 1996 & $1997 p$ \\
\hline Kraft & 227 & 226 & 215 & 232 & 245 \\
\hline Papel Monolúcido & 35 & 31 & 33 & 36 & 37 \\
\hline Caixas de Papelão & 1178 & 1295 & 1354 & 1475 & 1554 \\
\hline Duplex e Triplex & 238 & 263 & 300 & 323 & 347 \\
\hline Total & 1678 & 1815 & 1902 & 2066 & 2183 \\
\hline Crescimento em relação ao ano anterior & & $8,2 \%$ & $4,8 \%$ & $8,6 \%$ & $5,7 \%$ \\
\hline
\end{tabular}

Os materiais celulósicos têm principalmente a função de estruturação da embalagem, conferindo formatos diversos, que facilitam o manuseio, empilhamento e transporte, ao mesmo tempo conferem um baixo peso às embalagens. Possuem superfície adequada à impressão dos mais diferentes tipos e qualidade. Tais características possibilitam vasta utilização destes materiais, indo desde a contenção e proteção de produtos leves, tais como cigarros, fármacos, confeitos, sendo também usados na confecção de estruturas de grande porte, usados no acondicionamento de eletrodomésticos e peças automotivas (Mourad,1996). 
Outra característica significativa dos materiais celulósicos (Mourad,1996) é a sua reciclabilidade, chegando a quase $100 \%$ em alguns casos, o que economicamente torna estes materiais bastante viáveis e atrativos para a construção de embalagens (Mourad,1996).

A indústria de papéis no Brasil recicla anualmente 1,5 milhões de toneladas de papel, cartão e papelão ondulado e chega a importar outras 56 mil toneladas de aparas ${ }^{3}$ para reaproveitamento em seu processo produtivo (Ardito \& Garcia, 1989). Calderoni (1998), relata que em 1995 o consumo de aparas para a produção de papel foi de 1,84 milhões de toneladas, sendo $54,5 \%$ para a produção de papelão ondulado.

Na cidade de São Paulo, o papel e o papelão ondulado são responsáveis por $17 \%$ da composição do lixo em volume, seguido pelo plástico $7,5 \%$, metais $3,3 \%$ e vidro $1,5 \%$ (Ardito \& Garcia, 1989). Para o ano de 1993 , Calderoni (1998) relata que o papel e o papelão representavam $14,4 \%$ da composição em volume do lixo da cidade de São Paulo, seguido pelo plástico $12,1 \%$, metais $3,2 \%$ e vidro $1,1 \%$.

No Brasil, quase a totalidade do papel miolo utilizado na fabricação de papelão ondulado é feito a partir de aparas. A qualidade do miolo reciclado depende muito do tipo de aparas utilizada.

A maioria das vezes, o usuário de aparas não consegue ter controle sobre sua composição, o que pode acarretar perda de resistência do material reciclado (Ardito \& Garcia, 1989). A Figura 1.1 mostra quais são os materiais recicláveis, tanto no Brasil como nos E.U.A..

\footnotetext{
${ }^{3}$ Aparas - denominação conferida a papéis, sacos, papelões e congêneres, usados, e que são coletados para fins de reciclagem. Podem receber também a denominação "fibras secundárias".
} 


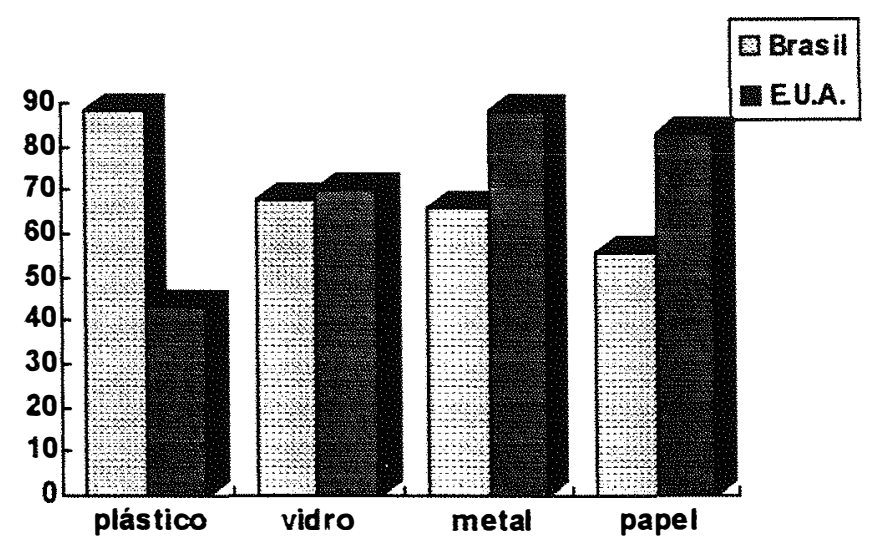

Figura 1.1 - Materiais recicláveis no Brasil e nos E.U.A. (DIL Consultants in Design and Marketing Communication, 1992)

No mercado de embalagens de materiais celulósicos, a agregação às suas características propriedades específicas, tais como o aumento de sua impermeabilização por meio da aplicação em sua superfície de revestimentos ou laminação com outros materiais, ampliando-se as possibilidades de sua utilização, podendo, entretanto, reduzir seu potencial de ser reciclado.

Assim, um dos grandes desafios da indústria de celulose e papel é a reciclagem de papéis revestidos e/ou laminados. Várias tentativas tem sido feitas no sentido de apresentar soluções para este problema, que na verdade não é um problema único e geral, sendo na maioria das vezes próprio de um tipo de embalagem ou dos materiais que compõem esta embalagem.

Por exemplo, no início de 1996, no Brasil, foi apresentado um processo de reciclagem para as embalagens do tipo longa vida, que possibilita a separação tanto das estruturas laminadas de papel, plástico e alumínio como retira revestimentos ou tintas de impressão inconvenientes para produção de polpa reciclada de boa qualidade (Regenex \& Tetra Pak Brasil, 1995). Este processo já é utilizado em Detroit (E.U.A.) e será implantado no México, mas 
sua aplicação tem se restringido, principalmente, a reciclagem de papelão ondulado revestido e papéis impressos.

Mais recentemente, foi desenvolvido pela Tetra Pak Brasil (Pinho, 1998) um outro processo de reciclagem para a embalagem Tetra Brik $\Theta$, denominado "Hidrapulper". Este tipo de embalagem é formado por multicamadas, respectivamente, de papel, plástico e alumínio

Neves ${ }^{4}$ comenta que, para a viabilização econômica de um processo de reciclagem de um material, não se tem só o desenvolvimento tecnológico do processo, mas também tem que se motivar a sociedade para recuperar este material e enviá-lo para a reciclagem. Por isso, a Tetra Pak Brasil tem trabalhado junto às prefeituras procurando fomentar a implantação de sistemas de coleta seletiva. Cabe informar que já existem 20 cidades brasileiras que fazem a coleta seletiva e já se coleta anualmente uma tonelada de embalagens usadas de Tetra Brik $\Theta$, que é reciclada.

O impacto negativo sobre o ambiente gerado pelo descarte de um tipo de embalagem feita com materiais com alta resistência a úmido, como é o caso da Tetra Brik $\circledast$, é grande e continua ocorrendo, sendo que as soluções vão aparecendo lentamente, sejam elas através da reciclagem ou da incineração destes materiais.

$\mathrm{Na}$ Figura 1.2, apresentam-se os dados coletados por Neder (1998), mostrando a tendência para a destinação final do lixo em diversos países e regiões.

\footnotetext{
${ }^{4}$ NEVES, F. Comunicação pessoal, 1999.
} 


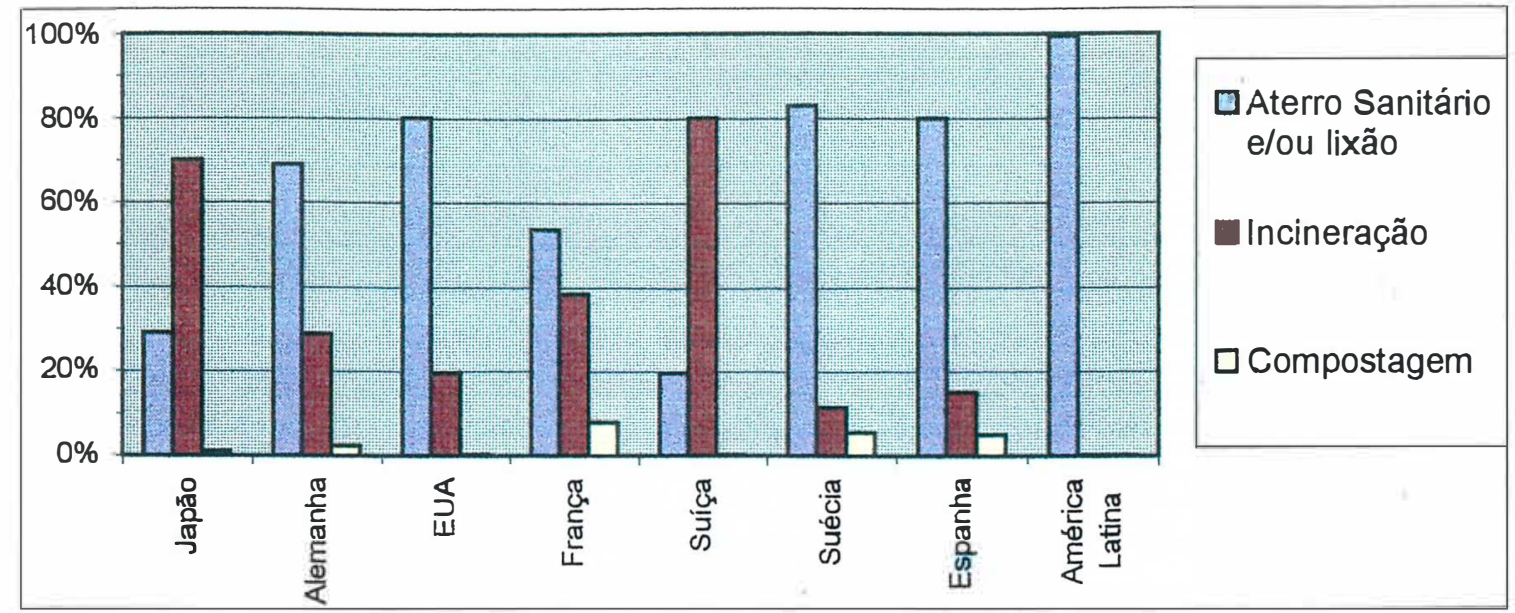

Figura 1.2 - Destinação final do lixo em diversos países e regiões - 1991 (Neder, 1998)

A literatura mostra (Quanto você sabe sobre embalagem e meio ambiente ... 1994) que no Brasil, o destino mais freqüente do lixo é o "lixão" e nas grandes cidades, $\mathrm{O}$ aterro sanitário. Normalmente, as embalagens ocupam um terço do volume nos aterros sanitários.

A degradabilidade ${ }^{5}$ dos diversos materiais no aterro sanitário é lenta e varia em função da suscetibilidade do material ser atacado por microorganismos elou do ataque químico da solução aquosa (chorume), presentes. Estudos realizados no IPT, mostram uma degradação mais acentuada para uma embalagem de alumínio quando comparada com uma embalagem laminada (plástico, alumínio e plástico) (IPT, 1993a).

A degradabilidade de embalagens laminadas papel/plástico e papel/plástico/alumínio é importante devido à sua interação com o meio

\footnotetext{
${ }^{5}$ Degradabilidade - é a suscetibilidade do material perder a suas características originais. Ela pode se dar pela ação das intempéries (calor, luz solar, água, ventos), microorganismos, insetos, animais, poluição e/ou efeitos mecânicos.
} 
ambiente, seja quanto ao aspecto de logística de descarte, capacidade do ambiente assimilar o lixo e tempo de vida da embalagem (ciclo de vida ${ }^{6}$ ).

Pelos problemas que causam, torna-se cada vez mais importante começar a pensar sobre como descartar convenientemente essas embalagens, seja esse descarte feito para sua degradação ou deterioração, seja reciclando, ou mesmo incinerando, mas que seja feita sempre de forma que elas façam parte de esquema de interação sustentável com o meio ambiente $^{7}$, ou seja, que seu descarte signifique a menor perturbação possivel dos recursos naturais.

Torna-se evidente que para se conseguir isso, é necessário conhecer o que acontece durante a degradação deste tipo de embalagem, a fim de se poder traçar planos com indicações adequadas de degradabilidade, incineração ou ainda reuso.

\footnotetext{
${ }^{6}$ Ciclo de Vida - compreende os estágios de vida de um produto, desde a aquisição da matériaprima, etapa de manufatura, transporte e distribuição, uso e reuso do produto, e, finalmente, reciclagem e disposição (Hunkeler \& Huang, 1997, p.253). De acordo com a SETAC - Society of Environmental Toxicology and Chemistry (Sociedade de Química e Farmacologia dos Estados Unidos) a Análise de Ciclo de Vida é definida como "um processo para i) avaliar as responsabilidades ambientais associadas a um produto, processo ou atividade por identificação e quantificação dos materiais e energia utilizados, gastos e liberados no ambiente; ii) estimar o impacto no ambiente deste material ou energia utilizados e liberados; e iii) identificar e avaliar oportunidades de melhorar os efeitos no ambiente." A Análise do Ciclo de Vida direciona seus estudos aos impactos ao ambiente nas áreas de saúde ecológica, saúde humana e esgotamento de recursos. Não é direcionada a considerações econômicas ou efeitos sociais.. "Interação sustentável com o meio ambiente significa estar compativel com o desenvolvimento sustentado, que "é aquele que atende às necessidades do presente sem comprometer a possibilidade das geraçōes futuras atenderem as suas próprias necessidades" (GLADWIN et al., 1995, p.876)
} 


\section{OBJETIVOS}

Os objetivos principais deste trabalho são: i) caracterizar embalagens constituídas de materiais celulósicos, laminadas ou revestidas, quanto à influência de suas propriedades de impermeabilidade e resistência a úmido no que diz respeito à sua degradabilidade após o seu descarte em condições de aterro sanitário e ii) adaptar metodologias laboratoriais para avaliação de degradação e ação das intempéries em embalagens multicamada.

Para atingir estes objetivos, o trabalho foi separado nas seguintes metas:

1) Levantamento das características dos principais componentes destas embalagens multicamadas;

2) Obtenção de dados que possibilitem fornecer subsídios à resolução do problema advindos seja de reciclagem ou do descarte deste tipo de embalagem;

3) Verificação dos aspectos que conferem uma interação da embalagem e o meio ambiente, dando-se ênfase aos problemas e soluções que aparecem e que estão sendo aplicadas;

4) Verificação da degradabilidade deste tipo de embalagem em condições simuladas ao aterro sanitário, intempéries, radiação ultravioleta e temperatura;

5) Fornecer alternativas de tratamento destes materiais e de melhor destinação deste tipo de material quando descartado. 


\section{REVISÃO DA LITERATURA}

\subsection{Embalagem}

Embalagem, de acordo com Bueno (1980), significa empacotamento, enfardamento ou encaixotamento. Entretanto, embalagem é conceitualmente muito difícil para se descrever e definir porque cada indivíduo tem seu próprio modo de reconhecê-la. Assim, embalagem é arte e ciência, é material e equipamento, é proteção, promoção, leis, logistica, fabricação e materiais de movimentação. Uma das definições mais completas é a de Pichler (1984) que define embalagem como a interface entre um produto e os ambientes físicos e sociais (ou culturais) de distribuição. Uma definição tão sintética somente é bem compreendida quando se discute um pouco mais o significado de cada um de seus termos.

Por exemplo, tem-se Hanlon (1971, p.1-7) que divide as embalagens em três categorias: a) as de consumo, b) as industriais e c) as de uso militar. A primeira é geralmente concebida em unidades pequenas e em grande quantidade, freqüentemente decorada de maneira atrativa. As embalagens industriais, em contraste, é usualmente fabricada em unidades grandes e resistentes, com nenhuma atenção à sua aparência estética. A de uso militar é um tipo altamente especializado, geralmente visando a proteção do material embalado. 
As funções das embalagens, de acordo com Hanlon (1971, p.1-20), são: estrutura, estética, estilo, comunicação, e requisitos legais. Recomenda que deve ser dada uma atenção especial à escolha do material a ser utilizado na fabricação da embalagem.

Segundo ele, os novos materiais de embalagem, como 0 plástico, são versáteis e de boa aparência, entretanto, não substituem em todas as situações os outros materiais, como o papel e o papelão ondulado . Estes últimos são materiais mais econômicos e ainda são os mais utilizados na fabricação da maioria das caixas. Os metais possuem elevada resistência e rigidez que são necessárias em certas aplicações especiais, pois possuem o inconveniente do alto peso somente a folha de alumínio provê absoluta barreira nas embalagens flexiveis. As garrafas e potes de vidro são quase sempre os preferidos na escolha, em lugar daqueles em material plástico, para a maioria dos produtos valiosos, e seria um erro assumir que eles serão inteiramente substituidos por materiais sintéticos.

Para determinados produtos, a utilização isolada dos diferentes materiais de embalagens, tais como, papel, papelão ondulado, cartão, madeira, plásticos, metais (alumínio e aço) e vidro, não é suficiente. Na busca de atender todas as funções da embalagem, a um custo mínimo e que resulte num produto competitivo, cresce cada vez mais a utilização de materiais combinados ou "compósitos". Os materiais podem ser combinados de diversas maneiras a fim de se obter uma embalagem de boa qualidade e com um custo agregado competitivo.

Nas estruturas combinadas, as propriedades de cada material componente é aproveitada e maximizada. A Tabela 3.1 mostra como cada 
material pode contribuir nas propriedades das estruturas multicamadas. Algumas estruturas comuns no mercado são apresentadas na Tabela 3.2.

Tabela 3.1 - Principais características de alguns substratos usados em estruturas combinadas

\begin{tabular}{|c|c|}
\hline Substrato & Característica \\
\hline Papel comum & $\begin{array}{l}\text { baixo custo, rigidez, resistência } \\
\text { mecânica }\end{array}$ \\
\hline Papel glassine $e^{\star \star}$ & $\begin{array}{l}\text { barreira à passagem de gorduras e } \\
\text { aroma }\end{array}$ \\
\hline Alumínio* & $\begin{array}{l}\text { boa aparência, barreira a luz, baixa } \\
\text { permeabilidade a gases e ao vapor de } \\
\text { água }\end{array}$ \\
\hline Celofane $^{\star \star}$ & $\begin{array}{l}\text { transparência, brilho, rigidez, boa } \\
\text { maquinabilidade }\end{array}$ \\
\hline Polietileno ${ }^{\star \star}$ & $\begin{array}{l}\text { baixo custo, baixa taxa } \text { de } \\
\text { permeabilidade ao vapor de água } \\
\text { (TPVA), termossoldável }\end{array}$ \\
\hline Polipropileno & rigidez, baixa TPVA, brilho \\
\hline$P V C^{\star \star}$ & $\begin{array}{l}\text { termossoldável, boa resistência } \\
\text { gorduras }\end{array}$ \\
\hline Saran ¿* $^{*}$ & |barreira a gases e umidade \\
\hline EVOH & | barreira ao oxigênio \\
\hline Poliéster (PET) & $\begin{array}{l}\text { resistência à tração, resiste à variações } \\
\text { na temperatura, resistência química, } \\
\text { brilho e boa transparência }\end{array}$ \\
\hline 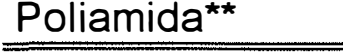 & baixa permeabilidade a gases \\
\hline
\end{tabular}

*Alcan. 1997; **Cabral. s.d. 
Tabela 3.2 - Exemplos de estruturas colaminadas e suas aplicações (Alcan, 1997)

\begin{tabular}{|c|c|}
\hline Aplicação & Estruturas $^{\star}$ \\
\hline $\begin{array}{l}\text { biscoitos, massas e } \\
\text { salgadinhos }\end{array}$ & $\begin{array}{l}\text { polipropileno(impresso)/adesivo/polipropileno perolizado } \\
\text { polipropileno(impresso)/adesivo/alumínio(dep.) })^{\star \star / p o l i p r o p i l e n o ~} \\
\text { polipropileno(impresso)/aluminio(dep.)/polietileno coex }{ }^{\star \star \star} \\
\text { PET(impresso)/adesivo/polietileno } \\
\text { PET(impresso)/adesivo/papel/polietileno }\end{array}$ \\
\hline café & $\begin{array}{l}\text { PET(impresso)/alumínio(dep.)/adesivo/polietileno } \\
\text { PET(impresso)/adesivo/polietileno coex } \\
\text { PET/adesivo/alumínio/adesivo/polietileno }\end{array}$ \\
\hline chocolates & $\begin{array}{l}\text { polipropileno(impresso) / alumínio(dep.) } \\
\text { aluminio (impresso)/adesivo/papel/"hot melt" }\end{array}$ \\
\hline $\begin{array}{l}\text { cigarros } \\
\text { (embalagem } \\
\text { interna) }\end{array}$ & alumínio (impresso)/adesivo/papel \\
\hline creme dental & polietileno(impresso)/adesivo/alumínio/adesivo/polietileno \\
\hline leite em pó & PET(impresso)/alumínio(dep.)/adesivo/polietileno \\
\hline manteiga & $\begin{array}{l}\text { alumínio(impresso)/adesivo/papel/"hot melt" } \\
\text { alumínio(impresso)/polietileno/papel }\end{array}$ \\
\hline rótulos & alumínio(impresso)/adesivo/papel \\
\hline $\begin{array}{l}\text { sachês para } \\
\text { fármacos }\end{array}$ & $\begin{array}{l}\text { papel(impresso)/polietileno/alumínio/polietileno } \\
\text { papel(impresso)/adesivo/alumínio/polietileno }\end{array}$ \\
\hline sachês para xampu & PET(impresso)/adesivo/alumínio/adesivo/polietileno \\
\hline sabonete & PET(impresso)/adesivo/papel/"hot melt" \\
\hline sorvetes & $\begin{array}{l}\text { papel(impresso)/polietileno } \\
\text { alumínio(impresso)/adesivo/papel/polietileno }\end{array}$ \\
\hline $\begin{array}{l}\text { sopas e sucos } \\
\text { desidratados }\end{array}$ & $\begin{array}{l}\mathrm{PET}(\mathrm{impresso} / \mathrm{adesivo/alumínio/adesivo/polietileno} \\
\text { papel(impresso)/polietileno/alumínio/polietileno }\end{array}$ \\
\hline $\begin{array}{l}\text { temperos e } \\
\text { condimentos }\end{array}$ & $\begin{array}{l}\mathrm{PET}(\text { impresso)/polietileno/alumínio/polietileno coex } \\
\mathrm{PET} \text { (impresso)/polietileno/alumínio/adesivo/polipropileno } \\
\text { alumínio(impresso)/"primer"/"hot melt"/papel } \\
\text { verniz/aluminio/polietileno/papel }\end{array}$ \\
\hline \multicolumn{2}{|c|}{ 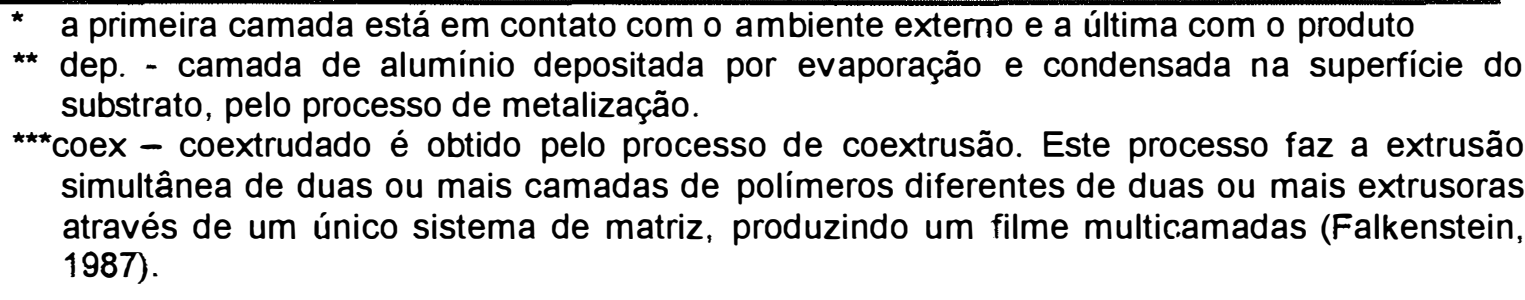 } \\
\hline
\end{tabular}

As embalagens de estrutura combinada utilizadas no acondicionamento de leite longa vida, sucos, molhos e outros produtos podem apresentar principalmente os seguintes materiais de embalagem: alumínio, cartão e polietileno. As caracteristicas destes materiais importantes para o projeto e fabricação destas embalagens estão descritas a seguir. 


\subsubsection{Aluminio}

Segundo Hanlon (1971, p.3-55), as folhas de alumínio usadas em embalagem que apresentam espessuras acima de $18 \mu \mathrm{m}$ são impermeáveis a umidade (vapor d'água) e gases. Espessuras muito finas apresentam microfuros que a tornam permeável. A resistência química a solventes e a gorduras é boa, mas a resistência à água é regular. A resistência a ácidos, exceto a ácidos muito fracos, e aos álcalis é pobre, a menos que ele seja protegido com um verniz ou cera. O alumínio, nesta forma, não é afetado pela luz ou por temperaturas abaixo de $288^{\circ} \mathrm{C}$.

A folha de alumínio, de acordo com Hanlon (1971, p.3-56), possui resistência ao rasgo e resistência à tração relativamente baixas, entretanto, em temperaturas muito baixas, a resistência mecânica melhora o que as tornam convenientes para as embalagens que ficam em ambientes frigoríficos. A refletividade do lado mais brilhante da folha é da ordem de $88 \%$ e do lado oposto é cerca de $80 \%$. A folha de alumínio é vulnerável a riscos e ä abrasão, caso for exposta, no entanto, a aplicação de um "primer " ou verniz pode ajudar a protegê-la. Pode ser adicionada tinta em tais revestimentos para produzir efeitos visuais interessantes, de forma que qualquer cor metálica pode ser obtida. Várias texturas são disponíveis.

Outra vantagem, ainda segundo Hanlon (1971, p.3-56), é que a folha de alumínio de baixo grau de têmpera dobra-se sem efeito de mola, o que ajuda na estruturação de formas bem definidas, embora, isto também a torne sujeita a rugas que podem conferir defeitos à superfície macia. 


\subsubsection{Cartão}

Barroti (1988, p.851) comenta que os cartões se caracterizam essencialmente por sua elevada gramatura e relativa rigidez, conforme requerida para a produção de cartuchos, caixas pequenas, etc. Existem para a fabricação de embalagens os cartões tipo duplex, triplex e branco. $O$ cartão duplex é composto de forro e suporte, nas gramaturas entre 200 e $600 \mathrm{~g} / \mathrm{m}^{2}$. O forro é a camada superior, geralmente fabricada com pasta química branqueada, do tipo monolúcido, com ou sem tratamento superficial.

O cartão triplex apresenta, como o próprio nome fala, três camadas. É análogo ao duplex, apresentando uma camada de suporte entre o suporte forrado e o forro, ou seja, é forrado em ambas as faces. Já o cartão branco é feito de uma só massa, dispostas em uma ou várias camadas, com acabamento de acordo com a finalidade e fabricado com pasta química branqueada.

Neves (1996), cita que as principais propriedades do cartão, as quais devem ser controladas para atender os requisitos de uma embalagem adequada ao produto, são: brilho e alvura (ópticas) ; rigidez e resistências à tração ( índice de tração), ao arrebentamento ( índice de arrebentamento), à dobras e à delaminação (mecânicas); e, de absorção de água, lisura, capacidade de impressão e resistência ao arrancamento superficial da fibras (desempenho gráfico). A título de exemplo, tem-se nas Tabelas 3.3 e 3.4 características típicas de alguns cartões encontrados no mercado brasileiro. 
Tabela 3.3 - Valores típicos de cartões nacionais (Klabin, 1999)

\begin{tabular}{|c|c|c|c|c|c|c|c|c|c|c|c|c|c|}
\hline Aplicações & $\begin{array}{r}\text { Em } \\
\text { mú } \\
c \\
\text { refri } \\
p \\
\text { ref }\end{array}$ & $\begin{array}{l}\text { oalage } \\
\text { tiplas } \\
\text { ivejas } \\
\text { jerante } \\
\text { oduto } \\
\text { igerad }\end{array}$ & $\begin{array}{l}\text { ns } \\
\text { de } \\
\text { es e } \\
\text { s } \\
\text { os }\end{array}$ & $\begin{array}{r}\text { Con } \\
p \\
\text { rest } \\
\text { que } \\
\text { at }\end{array}$ & $\begin{array}{l}\text { gelad } \\
\text { oduto } \\
\text { riados } \\
\text { iquem } \\
\text { nbient } \\
\text { ímido }\end{array}$ & $\begin{array}{l}\text { os e } \\
\text { s } \\
\text { ou } \\
\text { em } \\
\text { te }\end{array}$ & $\begin{array}{r}\text { Emb } \\
\text { líqui } \\
\mathrm{c} \\
\text { io } \\
\mathrm{ma} \\
\mathrm{pol}\end{array}$ & $\begin{array}{l}\text { lagen } \\
\text { dos: le } \\
\text { emes } \\
\text { gurtes } \\
\text { ionese } \\
\text { pas, e }\end{array}$ & $\begin{array}{l}\text { is de } \\
\text { eite, } \\
\text { es, } \\
\text { tc. }\end{array}$ & $\begin{array}{l}\text { Uso g } \\
\text { alimer } \\
\text { limpe } \\
\text { calça } \\
\text { fárma } \\
\text { etc }\end{array}$ & $\begin{array}{l}\text { eral: } \\
\text { tos, } \\
\text { zza, } \\
\text { dos, } \\
\text { cos, } \\
\text { c. }\end{array}$ & $\begin{array}{r}\text { Uso g } \\
\text { mai } \\
\text { rigid } \\
\text { (pó } \\
\text { "bag } \\
\text { box", }\end{array}$ & $\begin{array}{l}\text { eral, } \\
\text { ior } \\
\text { dez } \\
\text { j-in- } \\
\text { etc.) }\end{array}$ \\
\hline Gramatura $\left(\mathrm{g} / \mathrm{m}^{2}\right)$ & 310 & 350 & 390 & 310 & 350 & 390 & 205 & 245 & 285 & 350 & 385 & 355 & 390 \\
\hline Umidade (\%) & 7,5 & 7,5 & 7,5 & 7,5 & 7,5 & 7,5 & 7 & 7 & 7 & 7,5 & 7,5 & 7,5 & 7,5 \\
\hline Alvura ISO 2470 & 80 & 80 & 80 & 80 & 80 & 80 & 80 & 80 & 80 & 80 & 80 & 80 & 80 \\
\hline $\begin{array}{l}\text { Aspereza Bendtsen } \\
\text { cobertura (mL/min) }\end{array}$ & 200 & 200 & 200 & 200 & 200 & 200 & 200 & 250 & 250 & 200 & 200 & 100 & 100 \\
\hline \begin{tabular}{ll|} 
Res. & Rasgo \\
direção & longitudinal \\
(N) & \\
\end{tabular} & 4,4 & 4,7 & 5,6 & & & & & & & & & & \\
\hline \begin{tabular}{ll|} 
Res. & Rasgo \\
direção & transversal \\
(N) & \\
\end{tabular} & 5,3 & 5,5 & 6,4 & & & & & & & & & & \\
\hline $\begin{array}{ll}\text { Resistência } & \text { a } \\
\text { úmido }(\%) & \\
\end{array}$ & 80 & 80 & 80 & & & & & & & & & & \\
\hline $\begin{array}{l}\text { Resistência } \\
\text { flexão } \quad \text { à } \\
\text { geométrica }(\mathrm{mN})\end{array}$ & 230 & 340 & 470 & 300 & 450 & 620 & 75 & 140 & 230 & 450 & 600 & 450 & 600 \\
\hline $\begin{array}{l}\text { Absorção da base } \\
\left(\mathrm{gH}_{2} \mathrm{O} / \mathrm{m}^{2}\right)\end{array}$ & 45 & 45 & 45 & 35 & 35 & 35 & 50 & 50 & 50 & 45 & 45 & 45 & 45 \\
\hline $\begin{array}{l}\text { Absorção da } \\
\text { cobertura }\left(\mathrm{gH}_{2} \mathrm{O} / \mathrm{m}^{2}\right)\end{array}$ & 40 & 40 & 40 & 40 & 40 & 40 & 40 & 40 & 40 & 40 & 40 & 40 & 40 \\
\hline $\begin{array}{l}\text { Absorção de água } \\
(\%)\end{array}$ & & & & $<5$ & $<5$ & $<5$ & & & & & & & \\
\hline
\end{tabular}


Tabela 3.4 - Características de Cartões utilizados em embalagens de congelados (Cia. Suzano ${ }^{8}, 1994$ )

\begin{tabular}{|c|c|c|c|c|c|c|c|c|}
\hline \multirow{2}{*}{$\begin{array}{l}\text { característica } \\
\\
\text { gramatura } \\
\left(\mathrm{g} / \mathrm{m}^{2}\right)\end{array}$} & \multicolumn{4}{|c|}{$\begin{array}{c}\text { Cartão duplex, utilizado em } \\
\text { embalagens para } \\
\text { congelados }\end{array}$} & \multicolumn{4}{|c|}{$\begin{array}{c}\text { Cartão triplex, utilizado em } \\
\text { embalagens finas para } \\
\text { congelados }\end{array}$} \\
\hline & 300 & 350 & 400 & 450 & 300 & 350 & 400 & 450 \\
\hline espessura $(\mu \mathrm{m})$ & 390 & 455 & 543 & 610 & 381 & 445 & 508 & 571 \\
\hline umidade (\%) & 7,5 & 7,5 & 7,5 & 7,5 & 7,5 & 7,5 & 7,5 & 7,5 \\
\hline $\begin{array}{l}\text { Absorção lateral } \\
(\%)\end{array}$ & 6 & 6 & 6 & 6 & 6 & 6 & 6 & 6 \\
\hline $\begin{array}{l}\text { rigidez Taber - } \\
\text { longitudinal } \\
\text { (gf.cm) }\end{array}$ & 160 & 220 & 340 & 450 & 140 & 220 & 300 & 440 \\
\hline $\begin{array}{l}\text { rigidez Taber - } \\
\text { transversal } \\
\text { (gf.cm) } \\
\end{array}$ & 75 & 110 & 160 & 210 & 70 & 110 & 140 & 220 \\
\hline $\begin{array}{l}\text { rasgo } \\
\text { longitudinal }(\mathrm{g})\end{array}$ & 240 & 260 & 300 & 340 & 240 & 270 & 300 & 330 \\
\hline $\begin{array}{l}\text { alvura Elrepho } \\
0 \% \text { u.v. forro } \\
\text { (\%) }\end{array}$ & 83 & 83 & 84 & 84 & 83 & 83 & 84 & 85 \\
\hline $\begin{array}{l}\text { brilho Photovolt } \\
75^{\circ}(\%)\end{array}$ & 55 & 55 & 55 & 55 & 55 & 55 & 55 & 55 \\
\hline $\begin{array}{l}\text { cobb } 2 \text { minutos - } \\
\text { suporte }\left(\mathrm{g} / \mathrm{m}^{2}\right)\end{array}$ & - & |- & 30 & - & - & 30 & - & - \\
\hline
\end{tabular}

Self (1987) comenta que para adquirirem as propriedades que tornam os cartões úteis para este tipo de aplicação, ou seja, como embalagem, requer o uso de processos de produção e tratamentos químicos específicos. $\dot{E}$ deste modo que os papéis e cartões adquirem resistência à umidade; a denominada resistência a úmido ${ }^{9}$, opacidade, propriedades de barreira, etc.

\footnotetext{
${ }^{8}$ Cia. Suzano de Papel e Celulose. Comunicação por carta. 1994.

${ }^{9}$ Resistência à úmido - é a relação entre o valor da resistência à tração do papel em estado úmido e o valor da resistência à tração do mesmo papel em estado seco, ambos determinados sob condições específicas. Para papéis e cartões que apresentam colagem interna a resistência à tração úmida é determinada após saturação com água por período igual ou superior a $24 \mathrm{~h}$ (NBR 7986-83).
} 
Este autor comenta ainda que, alguns aditivos podem ser misturados à pasta antes do papel ser formado ou serem aplicados somente na sua superfície. Os primeiros são aditivos denominados "internos" e a operação é denominada "colagem interna". Isto é feito quando se aplica uma resina natural ou sintética à massa do papel ou cartão, de modo a conferir resistência à penetração de água. O papel formado com muita colagem interna é para ser utilizado em ambientes de umidade elevada. No caso do aditivo ser o sulfato de alumínio, têm-se a formação de um material hidrofóbico misturado ou aderido às fibras do papel.

Os aditivos externos, Self (1987) comenta, são aplicados como se fossem tintas, normalmente, na fase de acabamento do papel úmido. Aditivos superficiais podem ser utilizados para se obter resistência a óleos ou como selante, como é o caso da aplicação do amido na superfície do papel ("sizing"), afim de prover melhor desempenho nas máquinas de impressão (desempenho gráfico).

\subsubsection{Polietileno}

Bremer (1987), apresenta as principais propriedades que devem ser consideradas nas resinas de polietileno, tais como: densidade, índice de fluidez, distribuição do peso molecular. No caso de copolímeros de EVA (etil vinil acetato) é importante a proporção de cada um dos componentes. Conforme as combinações destas propriedades, resinas específicas podem ser projetadas para dadas aplicações de filmes.

O polietileno, comenta Parra (1995), é um polímero que apresenta tanto regiões cristalinas como amorfas. Como a densidade é uma medida da cristalinidade, tem-se que quanto mais cristalino este polímero maior 
sua densidade. Alterações na densidade (massa específica) ou na cristalinidade afetam as propriedades mais importantes do filme, como se exemplifica na Tabela 3.4 .

Bremer (1987) relata que durante a polimerização do polietileno $^{10}$, muitas cadeias poliméricas de diferentes comprimentos e pesos moleculares são produzidas. A propriedade que dá indicações sobre o tamanho destas cadeias é o índice de fluidez do polímero.

O índice de fluidez, segundo Bremer (1987), é definido como a quantidade de resina amolecida que flui através de um dado orifício em 10 minutos usando uma temperatura e uma pressão preestabelecidas. Resinas com baixo peso molecular médio fluem mais rápido e têm maiores índices de fluidez. Resinas para filmes têm índices de fluidez entre 0,2 a 7,0 g/10 minutos, sendo que alguns filmes de alta densidade têm estes índices inferiores a 0,05 g/10min.

Este pesquisador comenta ainda que os polímeros com cadeias menores ajudam na processabilidade ${ }^{11}$ enquanto que quando são relativamente maiores aumentam a resistência do filme. Através do controle das condições do reator ou pela aplicação de um catalisador consegue-se controlar melhor as quantidades relativas de cada tipo de cadeia. Para otimizar certas características dos polímeros, tais como, barreira ao vapor d'água e a gases, resistência à tração, é necessário calcular a distribuição específica adequada variando os pesos moleculares. Entretanto, generalizações a cerca de

\footnotetext{
${ }^{10}$ Polimerização do polietileno - é uma reação química, na qual uma molécula base (monômero) se une a outras iguais repetidas vezes formando uma cadeia polimérica. Esta cadeia pode apresentar ramificações. O grau de ramificação e o grau de cristalização definem a densidade do polímero (PARRA, 1995).

${ }^{11}$ Processabilidade - melhor desempenho nas máquinas de transformação de plástico, tais como, extrusoras, injetoras ou sopradoras.
} 
variações das propriedades em função de diferenças de distribuições de pesos moleculares são dificeis de serem feitas.

Tabela 3.5 - Propriedades dos filmes de polietileno (PARRA, 1995)

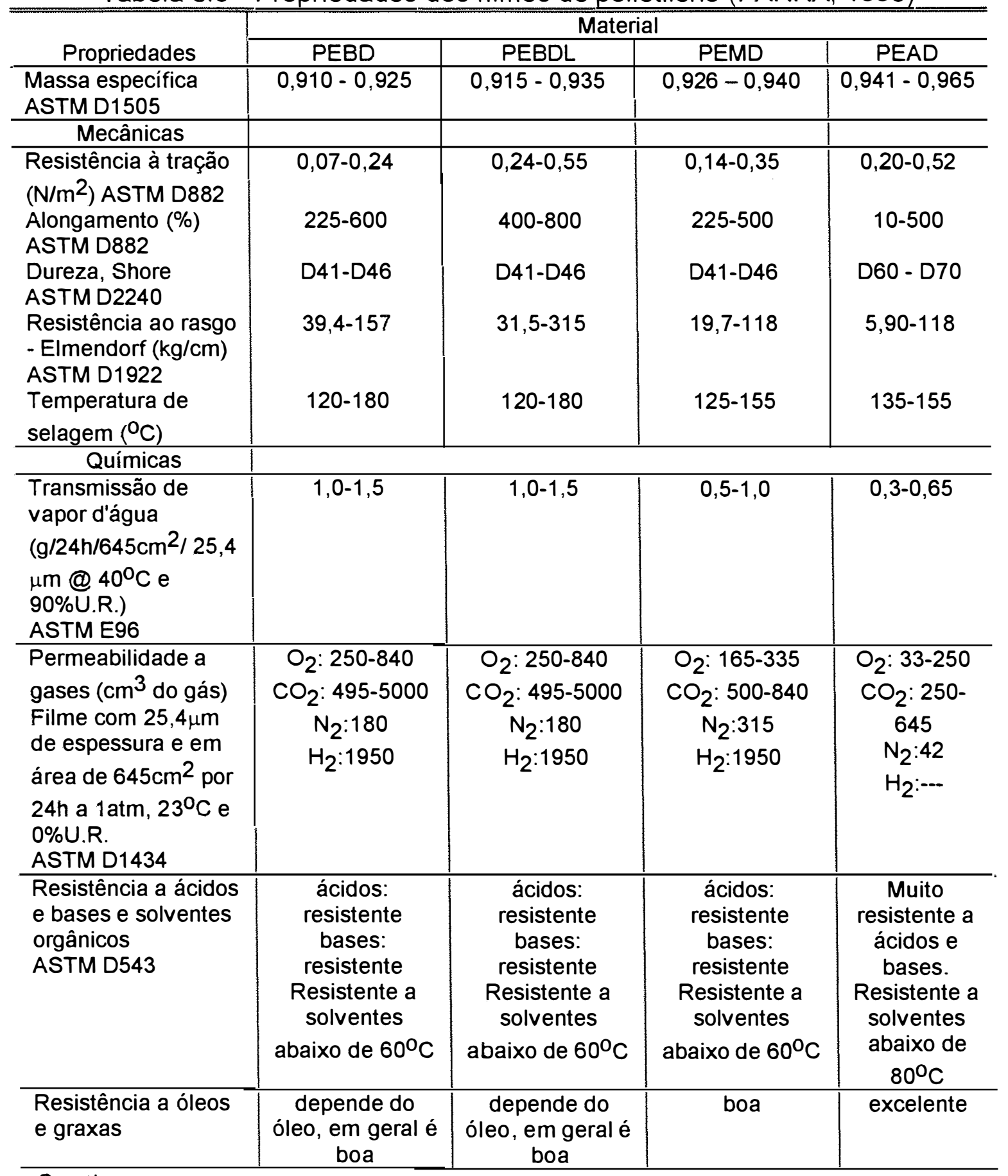

Continua 
continuação

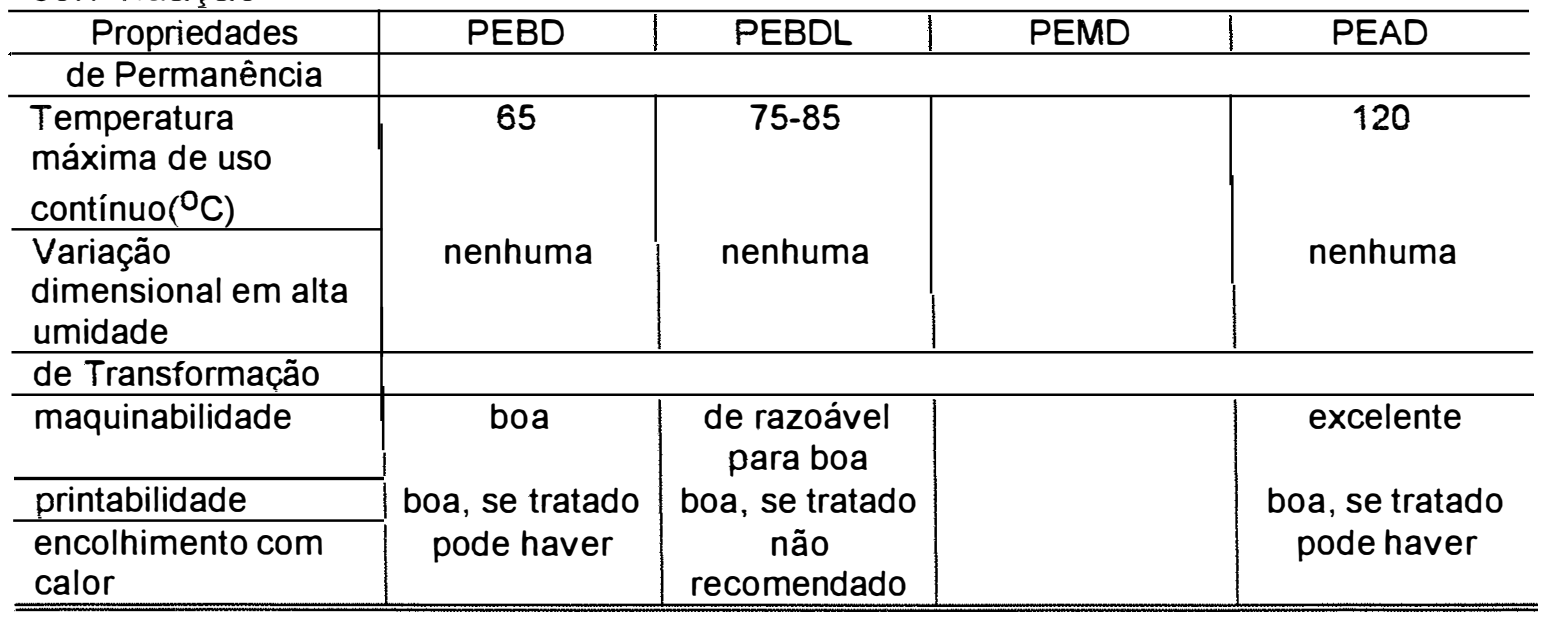

A adição de acetato de vinila (Bremer, 1987) nas cadeias de polietileno resulta na formação de mais regiões amorfas no filme, portanto, suas propriedades vão se alterar da mesma forma como se a densidade fosse menor. Geralmente, o conteúdo de acetato de vinila de um filme como EVA varia de 2 a 18\%, conforme a característica que se deseja alcançar para a embalagem. Este copolimero ${ }^{12}$ confere ao filme melhores propriedades de resistência mecânica em baixas temperaturas.

Parra (1995) relata que os filmes de polietileno podem conter aditivos funcionais, tais como, agentes deslizantes, anti-blocantes ${ }^{13}$ e antioxidantes e que na maioria dos casos, são incorporados pelo produtor da resina, mas podem também, ser adicionados pelo fabricante do filme utilizando "masterbatches"e concentrados. Estes aditivos conferem ao filme propriedades indispensáveis para sua aplicação em embalagens.

${ }^{12}$ Copolímero - eles são obtidos a partir de dois ou mais monômeros diferentes, como neste caso, o monômero de etileno e o acetato de vinila.

${ }^{13}$ Anti-blocantes - são aditivos que impedem a adesão de várias camadas do filme quando em formato de bobina. Estes podem ser materiais naturais ou ceras manufaturadas, sais de ácidos graxos, e vários polímeros, como polivinil álcool, poliamida, polietileno, polisilano e fluoroplásticos e muitas vezes compostos inorgânicos como silicatos e sílicas (O'Connor.1987). 
O rápido crescimento da utilização de polietileno em embalagens deu-se pela facilidade dos produtores conferirem ao filme propriedades "sob encomenda" para determinada aplicação. A escolha correta do filme depende do conhecimento do produto a embalar, do processamento e do ambiente de distribuição, que definem quais propriedades são relevantes para serem controladas. Por exemplo, embalagens para comida congelada requerem um bom desempenho mecânico do filme em baixas temperaturas, portanto um filme com EVA é mais adequado. Outro exemplo se tem quando o filme vai alimentar uma linha de enchimento de alta velocidade e é desejável manter uma certa transparência. Neste último caso, o filme mais recomendado é o de média densidade. Caso a embalagem precise de um filme que vai agir como barreira a água, gás ou gorduras é melhor utilizar o polietileno de alta densidade.

O comportamento das embalagens laminadas com relação a barreira ao vapor d'água e a gases possui particularidades e será abordado no item 3.4.

\subsection{Revestimento e Laminação de Materiais Celulósicos}

\subsubsection{Revestimento}

Os revestimentos aplicados, em forma de soluções ou emulsão de polímeros, na superfície do papel conferem diferentes propriedades às embalagens celulósicas.

Kuan \& Benazzi (1988) relatam que os revestimentos quando aplicados ao papel, conferem melhor qualidade de impressão, aparência, ou 
propiciam alguma propriedade funcional particular ao produto final. Eles sugerem a seguinte classificação para os revestimentos:

- Revestimento para impressão: quando se deseja melhorar a qualidade de impressão;

- Revestimentos decorativos: quando se deseja aprimorar a aparência do papel;

- Revestimentos funcionais: quando se deseja promover alguma propriedade específica, como, por exemplo: resistência à umidade, vapor de água, gás, óleo, gordura e aderência sob ação de calor.

Mourad (1996) apresenta alguns dos tipos de revestimentos funcionais utilizados largamente em embalagens: os que conferem ao papel propriedades de resistência (a óleos e gorduras, à absorção de água, à umidade, à abrasão), os antiaderentes, os antideslizantes e os específicos para embalagens tipo "skin.

De acordo com Mourad (1996), os revestimentos que formam barreiras ä passagem de óleos (no estado líquido) ou gorduras (no estado sólido), são compostos de produtos de base aquosa formulados com acrílico ou misturas poliméricas, com diferentes faixas de viscosidade. Seu emprego requer a utilização de adesivos de base aquosa ou "hot melts" na colagem das embalagens.

O teste mais comum para medir a resistência ä passagem de óleos ou graxas é chamado Teste Kit 3M, de acordo com a norma TAPPI 557. Neste teste, os papéis revestidos são submetidos a uma série de misturas de óleo e solventes cada vez mais fortes, numerados de 1 (baixo) a 12 (alto). A 
mistura mais forte, ou seja, com número mais alto, que deixa de penetrar no revestimento é denominado "número kit".

Os produtos que requerem o revestimento resistente a óleos e gorduras na sua embalagem são, por exemplo, bolos, pães, biscoitos, pizzas, manteiga, queijos, chocolates, balas, produtos cárneos, etc.

Nas embalagens, a absorção de água pela fibra celulósica torna-a menos rígida, diminuindo drasticamente suas propriedades de resistência mecânica.

A resistência à penetração d'água, de acordo com Mourad (1996), significa que a velocidade de penetração de água é baixa. Usualmente, a resistência à absorção de água é medida pelo ensaio de "Cobb" (NBR 7153, 1982; TAPPI T441, 1984). Neste ensaio, uma área determinada do papel revestido é deixada em contato com uma quantidade definida de água por um período estipulado de tempo. Antes e no final deste período, determina-se a massa da amostra. Por diferença, tem-se a quantidade de água absorvida.

Mourad (1996) comenta que os revestimentos que conferem ao papel a resistência à absorção de água são dispersões aquosas à base de acrílico ou de silicone, que podem ser repolpáveis, permitindo a reciclagem, dentro de determinados níveis. Além da impermeabilização, estes revestimentos facilitam a remoção de poeiras e reduzem a porosidade dos materiais celulósicos.

Estes revestimentos são utilizados em embalagens de produtos cárneos congelados e resfriados, frutas e vegetais, queijos, comidas pré- 
processadas, estocados em áreas cobertas e onde possa ocorrer condução de água como câmaras de resfriamento ou congelamento.

Mourad (1996) relata ainda que a resistência à absorção de umidade significa que a penetração da umidade acontece a uma baixa velocidade. A propriedade que determina a resistência do papel à umidade é a taxa de permeabilidade ao vapor de água (TPVA), determinada conforme as normas TAPPI T464, 1995 e ASTM E96, 1994.

Algumas empresas, no exterior, segundo Mourad (1996), têm desenvolvido produtos à base de copolímeros de etileno, que chegam a conferir para o papel kraft calandrado, em aplicações de 10 a $35 \mathrm{~g} / \mathrm{m}^{2} / 24 \mathrm{~h}$ de revestimento, TPVA's na faixa de 3 a $14 \mathrm{~g} / \mathrm{m}^{2} / 24 \mathrm{~h}$. Estes produtos oferecem ainda, boas características de selagem, colagem, impressão e reciclabilidade, sem a necessidade de serem removidos como os filmes de polietileno. Estes revestimentos são indicados para papéis finos, cartões, produtos sensiveis à corrosão, produtos higroscópicos, etc.

Mourad (1996), relata também que os revestimentos utilizados em papel para proporcionar resistência à abrasão são poliméricos solúveis em água, às vezes, usados em combinação com parafina. Tais revestimentos são bastante requisitados para embalagens de papelão ondulado usadas em eletrodomésticos e peças automotivas, em separadores, em cantoneiras, etc.

Os revestimentos antiaderentes evitam que o papel ou cartão fiquem aderidos a produtos pegajosos. Em casos, como por exemplo, da carne fresca (produto molhado) que adere à embalagem quando submetida a secagem ou congelamento. A propriedade de aderência pode ser medida através da adesividade da fita adesiva (TAPPI UM463, 1995). 
Mourad (1996) relata que os produtos aquosos à base de silicone são usados como revestimentos antiaderentes de embalagens em contato com borracha e os "hot melts" são bastante utilizados como base de etiquetas. Atualmente, em alguns países, são disponiveis para papéis com fins de confeitaria.

Os revestimentos antideslizamento ajudam a manter a estabilidade de embalagens paletizadas, quando em movimento. Dois tipos principais de produtos, de acordo com Mourad (1996), encontrados são de sílica ou de alumínio (alumina), ambos coloidais. A sílica é um material mais duro e de partículas maiores que alumina, provocando maior atrito. Isto significa que empilhamentos de embalagens revestidas com sílica podem ser inclinados de ângulos maiores sem que ocorra escorregamento.

Os revestimentos para embalagens tipo skin, de acordo com Mourad (1996), são constituídos de materiais poliméricos O processo para formar a embalagem tipo skin ( pele) envolve o posicionamento do papel, a aplicação do revestimento (mais conhecido como primer), a colocação do material a ser embalado, o filme plástico, calor e vácuo. Estes revestimentos são desenvolvidos para proporcionar a colagem entre o material celulósico e os filmes utilizados como skin.

A aplicação deste tipo de revestimento é utilizada para confecção de embalagens de transporte tipo skin de ferramentas, pequenas peças domésticas de reposição, etc. 


\subsubsection{Laminação}

A laminação, ou seja, onde ocorre a combinação de materiais diferentes, é o mais importante artifício da indústria de embalagens flexíveis. Ela compreende a conversão de substratos, tais como, papel, folha de alumínio e filmes plásticos, em produtos mais funcionais e de maior valor. Selecionando corretamente as matérias primas e o processo de laminação, os transformadores são capazes de controlar as propriedades dos laminados para que atendam as exigências do uso.

Hanlon (1971, p.13-9), comenta que os transformadores utilizam como matérias primas o papel, folhas de alumínio, adesivos e resinas para o uso na laminação e revestimento. Entretanto, a laminação não é um processo simples, que geralmente exige muitas etapas que são realizadas durante a passagem do produto através de equipamentos específicos. Por outro lado, por exemplo, o papel pode ser impresso e receber revestimento para selagem por fusão em uma única operação. A combinação das etapas de transformação reduz o custo da laminação.

Buttler (1985) comenta que a folha de alumínio é largamente utilizada como material de embalagem por causa de sua excelente propriedade de barreira à umidade e ao sabor, entretanto, quando em pequenas espessuras são incapazes de se auto-suportarem devido à sua falta de rigidez e de resistência à perfuração.

Segundo Buttler (1985), em uma laminação, por exemplo, de papel/polietileno/folha de alumínio/polietileno, as propriedades da folha são preservadas enquanto se atinge outros objetivos ao mesmo tempo. O papel, neste caso, pode ser impresso e oferece resistência mecânica e o polietileno 
melhora a resistência à perfuração e à resistência ao rasgo da folha de alumínio, como também, confere uma camada selável por calor. Este tipo de laminação é muito utilizado para obter embalagens de produtos sensíveis à umidade e ao oxigênio.

Hanlon (1971, p.13-9) descreve quatro métodos básicos de laminação:

a. Por adesivos à base de água ou outro solvente, que necessitam de evaporação do veículo no laminado para que os substratos se unam;

b. Por revestimento termoplástico, que requer calor e pressão para laminar;

c. Por laminação por extrusão, na qual uma camada de plástico derretido é aplicado através de uma fenda estreita em um cabeçote próximo a uma folha de papel ou filme que se movimenta; e

d. Por revestimento hot melt que difere do revestimento por extrusão por ser feito em uma temperatura mais baixa com uma mistura de cera e outros materiais com baixo ponto de fusão.

O processo mais utilizado para confecção de estruturas com papel é o que utiliza adesivos. $\mathrm{Na}$ composição de estruturas mais complexas, utiliza-se laminação por extrusão. Os demais processos são mais utilizados na produção de laminados plásticos. 


\subsection{Formação de embalagens cartonadas (laminadas)}

São apresentados neste item dados sobre os três sistemas principais de formação de embalagens cartonadas: o Tetra Brik, o Combiblok e o Liquipak, todos cobertos por patentes.

Oliveira \& Padula (1988) relatam que em 1961, a Tetra Pak introduziu seu primeiro sistema de acondicionamento asséptico em embalagens cartonadas, o qual evoluiu para o sistema Tetra Brik ${ }^{14}$, amplamente utilizado nos dias atuais. Este sistema tem como principio utilizar o material diretamente de bobinas formando um tubo contínuo através de soldagem longitudinal. Posteriormente, é feito o enchimento deste tubo e soldagem de topo e fundo sobre o produto, de modo a se obter uma embalagem sem espaço-livre (Figura 3.1).

Oliveira \& Padula (1988) comentam sobre a conveniência da ausência de espaço-livre para grande parte dos produtos alimentícios, visto que o oxigênio possibilita diversas reações indesejáveis, entre as quais aquelas que resultam em rancemificação, escurecimento e perda de valor nutritivo dos alimentos. Por outro lado, a falta de espaço-livre é indesejável no caso de produtos que precisam ser agitados antes do consumo. Nestes casos, um sistema alternativo permite que seja feita a injeção de um gás inerte.

O fato da soldagem transversal, de acordo com Oliveira \& Padula (1988), ser feita sobre o produto limita a utilização do sistema a produtos que não contêm partículas, uma vez que a presença deste tipo de material na área de soldagem pode prejudicar a hermeticidade da embalagem.

\footnotetext{
${ }^{14}$ marca registrada da Tetra Pak
} 
Entretanto, estão sendo feitos estudos afim de permitir o envase de produtos particulados.

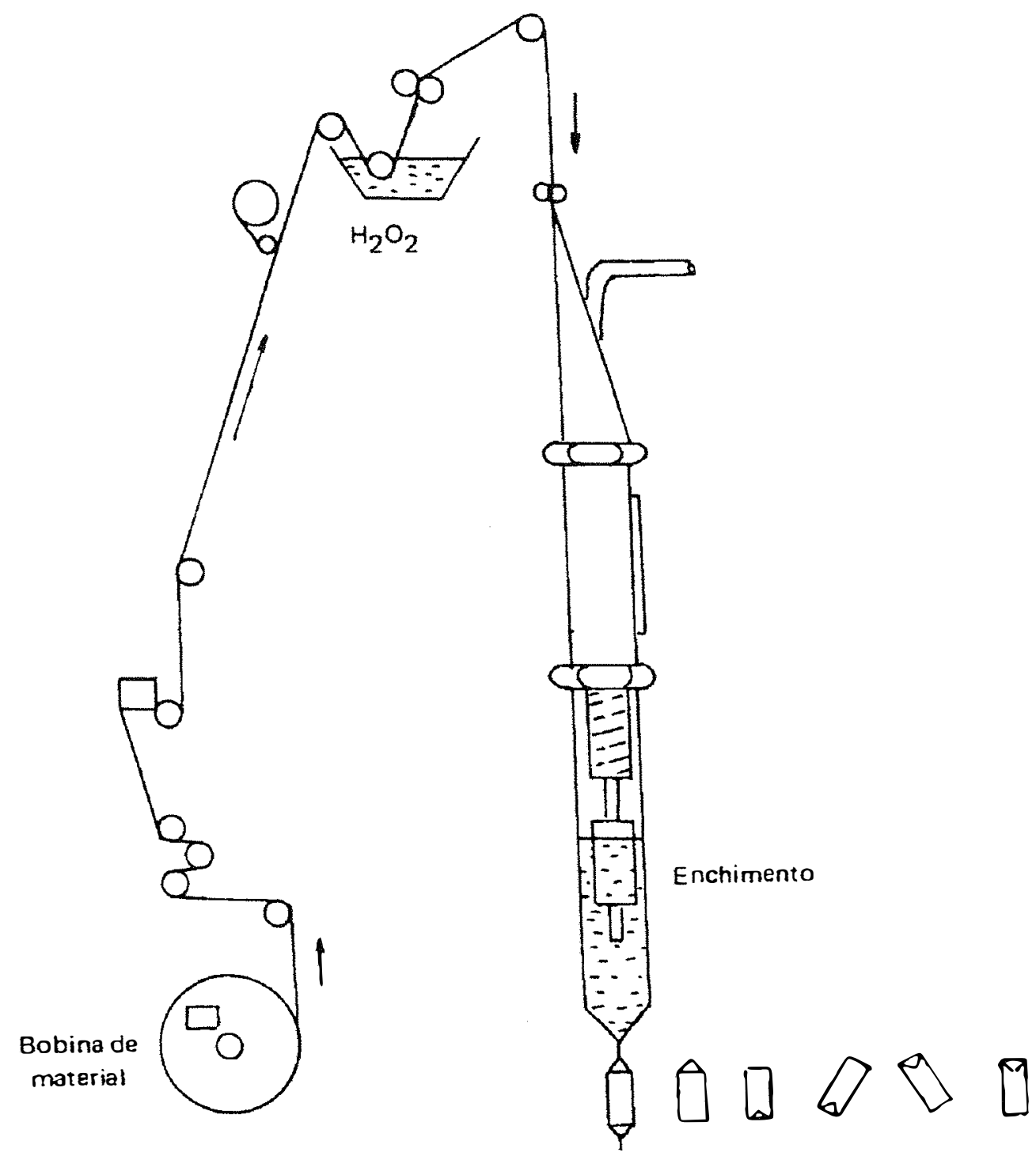

Figura 3.1 - Esquema do sistema Tetra Brik ${ }^{\circledR}$

Alves \& Ardito (1996) descrevem uma variação desse sistema, ou seja, a tecnologia desenvolvida pela International Paper, onde a termossoldagem longitudinal é feita lado interno/lado interno (tipo fin seal) (item c da Figura 3.2), o que dispensa o uso de fita plástica para evitar o contato do produto com as bordas do material de embalagem. Outros tipos de 
termossoldagem longitudinal de embalagens assépticas cartonadas também, são apresentadas na Figura 3.2.

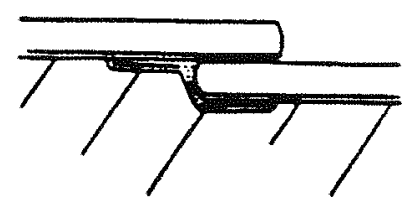

a

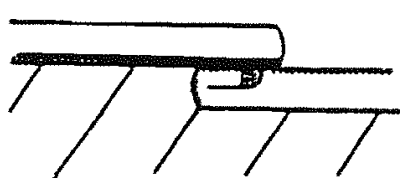

b

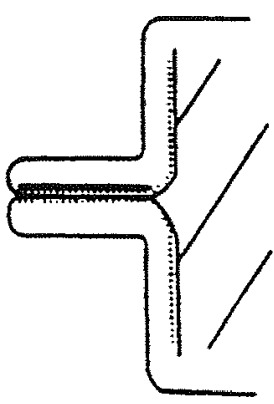

C

Figura 3.2 - (a) selagem lado interno/lado externo com sobreposição de fita plástica (Tetra Brik e Fuji); (b) selagem chanfrada (cortada e dobrada) evita que o produto entre em contato com o cartão (embalagens pré-fabricadas); (c) selagem lado interno - lado interno (sistema International Paper).

No sistema Tetra Brik, relatam Oliveira \& Padula (1988), a esterilização do material de embalagem é feita por imersão em banho de peróxido de hidrogênio com concentração de $32 \%$ e a remoção do excesso deste peróxido é feita pela ação combinada de compressão mecânica por cilindros e jatos de ar aquecido em ambas as faces do material.

A estrutura básica do material da embalagem Tetra Brik é polietileno/cartão/polietileno/alumínio/poliolefina. O polietileno externo é responsável pela proteção à impressão. O cartão utilizado é do tipo duplex, sendo a superfície externa branqueada e a interna não branqueada e sua principal função é dar rigidez à embalagem. A camada intermediária de polietileno auxilia na resistência da embalagem, além de unir a folha de alumínio ao cartão. A folha de alumínio é a principal responsável pelas características de barreira à luz e a gases. Por fim, a poliolefina interna é a responsável pelo fechamento hermético da embalagem. 
Esta poliolefina interna, de acordo Oliveira \& Padula (1988), pode ser composta por duas camadas como, por exemplo, polietileno/polietileno ou Surlyn (ionômero)/polietileno e a opção de uso vai depender das características do produto envasado. Para produtos ácidos a opção é usar o ionômero para proteger o alumínio de compostos agressivos do produto.

O sistema Tetra Brik opera com embalagens de diferentes capacidades. No Brasil, há equipamentos disponiveis para embalagens entre $200 \mathrm{ml}$ e $1000 \mathrm{ml}$. A velocidade do equipamento está por volta de 75 embalagens por minuto para recipientes com 200 a $250 \mathrm{ml}$.

Oliveira \& Padula (1988) descrevem também, o sistema Combibloc desenvolvido pela PKL, empresa alemã. Neste sistema, as préformas dos cartuchos (vincados e com a soldagem lateral feita) são introduzidos no equipamento. O uso de embalagens pré-formadas, segundo 0 fabricante, permite maior versatilidade do equipamento que, com um simples ajuste de altura, desde que sejam mantidas as dimensões da base, pode acondicionar diferentes capacidades. Um mesmo equipamento é capaz de trabalhar com embalagens de 500, 700 e $100 \mathrm{ml}$ ou 200, 250 e $500 \mathrm{ml}$ e permite o envase de embalagens com até 2 litros de capacidade.

Os cartuchos, de acordo com Oliveira \& Padula (1988), são mantidos em um magazine que alimenta a máquina (Figura 3.3). Ao entrarem na zona estéril, os cartuchos já estão abertos e com o fundo formado. A superfície interna da embalagem é esterilizada por peróxido de hidrogênio aplicado na forma de spray. Ar quente seca a embalagem. São feitos então o envase de produto e a soldagem de topo por ultra-som. A soldagem é feita 
acima do nível de enchimento, o que permite o acondicionamento de produtos particulados.

A estrutura do material de embalagem para 0 sistema Combibloc varia de acordo com o tipo de produto a ser envasado e a capacidade da embalagem. Basicamente são utilizadas estruturas do tipo cartão/plástico/alumínio/cartão/plástico.

O sistema americano Liquipak, relatam Oliveira \& Padula (1988), produzido pela empresa do mesmo nome é o único sistema de acondicionamento asséptico em embalagens cartonadas onde o topo da embalagem não é do tipo chato e sim do tipo chamado de top gable (Figura 3.4)

No sistema Liquipak, o equipamento também opera a partir de embalagens pré-formadas, de acordo com Oliveira \& Padula (1988), e, para esterilização destas utiliza-se uma solução de peróxido de hidrogênio com baixa concentração, algo em torno de $1 \%$. aplicada por spray aliada à elevada dosagem de radiação ultravioleta. Os dois agentes atuam conjuntamente, garantindo um alto efeito bactericida. O uso desse nível de concentração de peróxido garante, inclusive, que em embalagens com capacidade de um litro seja atingido o residual exigido pela FDA (Food and Drugs Administration) de 0,1 ppm, antes que o processo de esterilização seja completo.

O sistema Liquipak de enchimento das embalagens, descreve Oliveira \& Padula (1988), utiliza componentes plásticos que restringem o uso de temperatura acima de $100^{\circ} \mathrm{C}$ durante a esterilização do equipamento. Sendo assim utilizam-se, nessa etapa, agentes químicos. O fechamento da embalagem é feito acima do nível de enchimento do produto. 


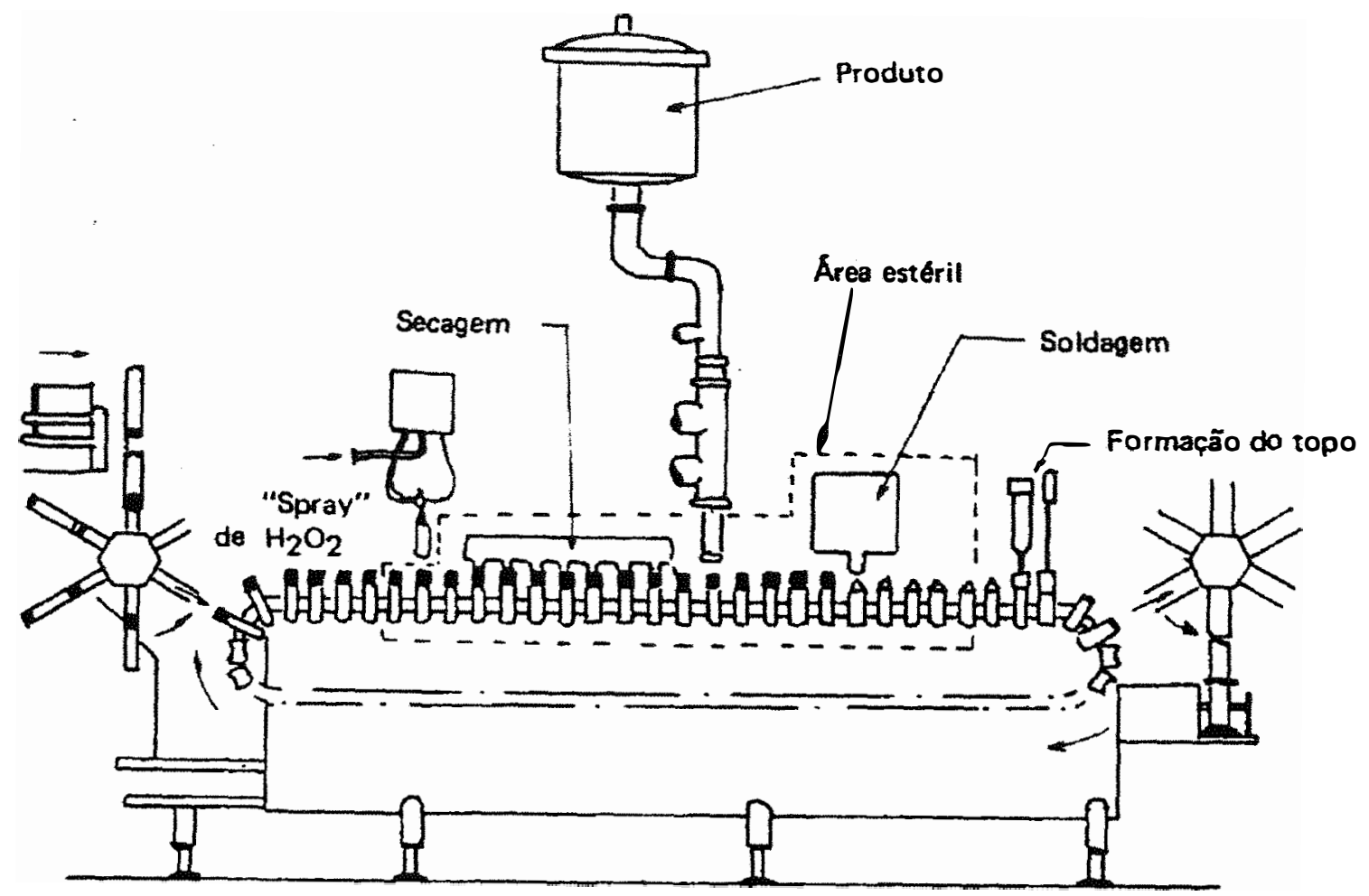

Figura 3.3 - Sistema Combibloc

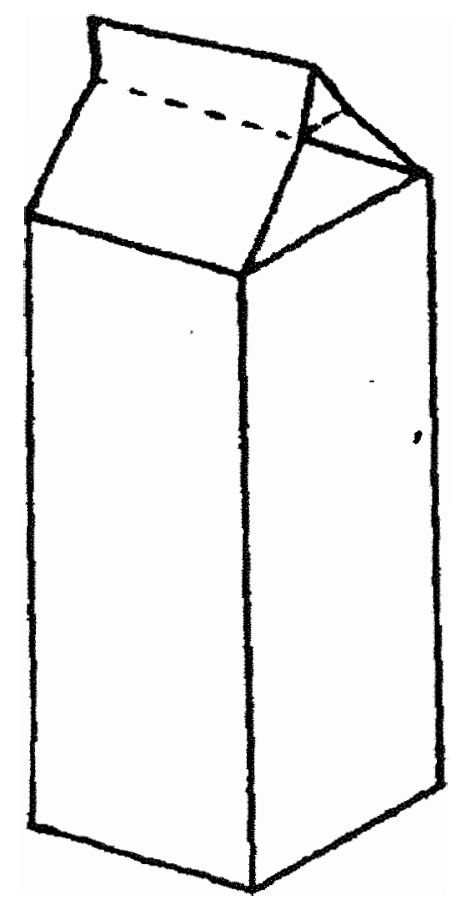

Figura 3.4 - Embalagem do sistema Liquipak 


\subsection{Permeabilidade de Materiais Laminados}

A permeabilidade é definida como a passagem ou difusão de um vapor, líquido ou sólido através de uma barreira sem afetá-la física ou quimicamente (Modern Plastics Encyclopedia, 1970).

O conhecimento da composição do material laminado não é suficiente para predizer o desempenho na permeabilidade, o processo usado na fabricação deve ser conhecido. Ainda assim, a permeabilidade total de um material laminado, de acordo com Hennessy et al. (1967), pode ser estimada pela soma das reciprocas da permeabilidade de seus componentes, como na expressão (3.1).

$$
\frac{1}{P}=\frac{t_{1}}{T P_{1}}+\frac{t_{2}}{T P_{2}}
$$

onde,

$P=$ permeabilidade do laminado

$P_{1}$ e $P_{2}=$ permeabilidade das camadas 1 e 2

$T=$ espessura total

$t_{1}$ e $t_{2}=$ espessuras das camadas 1 e 2

A estimativa, relatam Hennessy et al. (1967), tem validade prática aproximada, porque a permeabilidade dos componentes pode diferenciar grandemente após a laminação. A permeabilidade do laminado tende a aproximar-se da permeabilidade do componente menos permeável. Por esta razão, a equação é pouco utilizada, sendo mais necessária quando componentes têm permeabilidade da mesma ordem. A equação também pode 
ser usada para predizer a permeabilidade de estruturas feitas com componentes de espessuras diferentes.

No entanto, recomendam Hennessy et al. (1967), que deve-se ter o cuidado na interpretação dos resultados. Por exemplo, se as propriedades de barreira (permeabilidade) de uma estrutura composta por alumínio/papel/filme plástico são medidas pelo método onde utiliza-se uma folha do material, o resultado certamente será zero para vapor de água ou gases. Na prática, este laminado permite somente uma pequena vida de prateleira porque a difusão pode dar lugar à absorção através das laterais do papel, no canto da área de selagem. Neste caso, os materiais de barreira (plástico e alumínio) utilizados tornam-se ineficientes. Estes efeitos são mostrados na Figura 3.5.

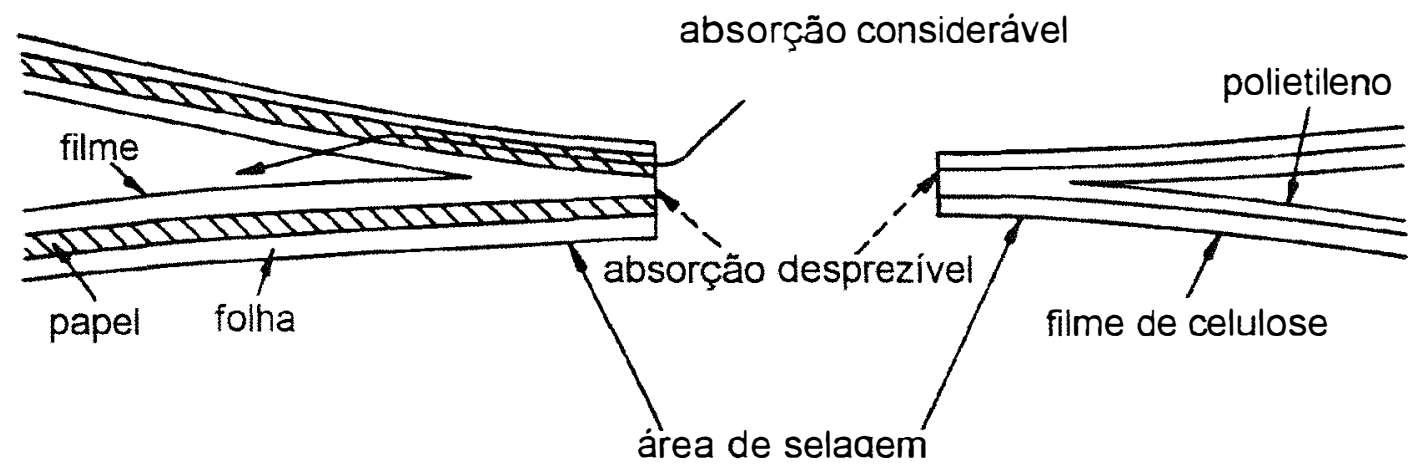

Figura 3.5 - Diagrama para mostrar como ocorre a absorção na área de selagem.

Certamente os laminados são permeáveis em diferentes graus dependendo de qual lado da amostra está em contato com o gás de ensaio. Isto ocorre particularmente onde um dos filmes é hidrofílico e consequentemente, mais permeável à elevada umidade relativa. Por essa 
razão, Hennessy et al. (1967) recomendam também que o ensaio seja feito pelo lado apropriado do laminado.

Hennessy et al. (1967) relatam que a folha de alumínio é a mais efetiva barreira usada em laminados flexiveis. Espessuras de 0,009 a 0,040mm são geralmente usadas, devido ao baixo custo e flexibilidade. Estes materiais, teoricamente, formam uma barreira hermética, mas na prática, vincos, dobras e manuseio, em geral, formam microfuros, particularmente nas espessuras abaixo de 0,020 mm. Estes microfuros permitem a passagem de vapor de água.

Os microfuros podem ser encontrados até mesmo na bobina de folha de alumínio fornecida pelo fabricante. No entanto, os danos podem ser causados pelo convertedor através do manuseio nas operações de impressão e laminação, e no final do estágio, durante o manuseio da embalagem acabada.

Deste modo, Hennessy et al. (1967) relatam que a passagem de vapores e gases através do laminado (estruturas com alumínio) depende do efeito da porosidade da folha de alumínio e da permeabilidade do filme plástico.

Com estes precedentes, Hennessy et al. (1967) recomendam, para a determinação da permeabilidade de materiais multicamadas, os métodos que empregam a embalagem inteira. Isto implica que os métodos que utilizam formato de folha são limitados quando aplicados em materiais flexiveis e recomenda-se os pouches contendo gás de ensaio que devem ser selados a quente e periodicamente examinados, por exemplo, pela análise de cromatografia. Garrafas plásticas revestidas são geralmente testadas pela medida de perda de peso quando contém líquido de teste. 


\subsection{Descarte das Embalagens}

\subsubsection{Situação atual}

A maior utilização de embalagens é o reflexo do progresso num país, pois, por um lado, o uso de embalagens está relacionado à venda de bens duráveis, por exemplo, geladeiras, fogões, etc., por outro lado, está ligado também à venda de produtos alimentícios, farmacêuticos, cosméticos, escolares, etc., que são vetores indicadores da atividade econômica de um país. Por outro lado, um maior consumo de embalagens também pode significar menos desperdício de alimentos, ou ainda, a existência de um consumidor bem mais exigente. Estes aspectos são evidenciados pela composição dos resíduos gerados pelos diversos países, como mostrado na Figura 3.6.

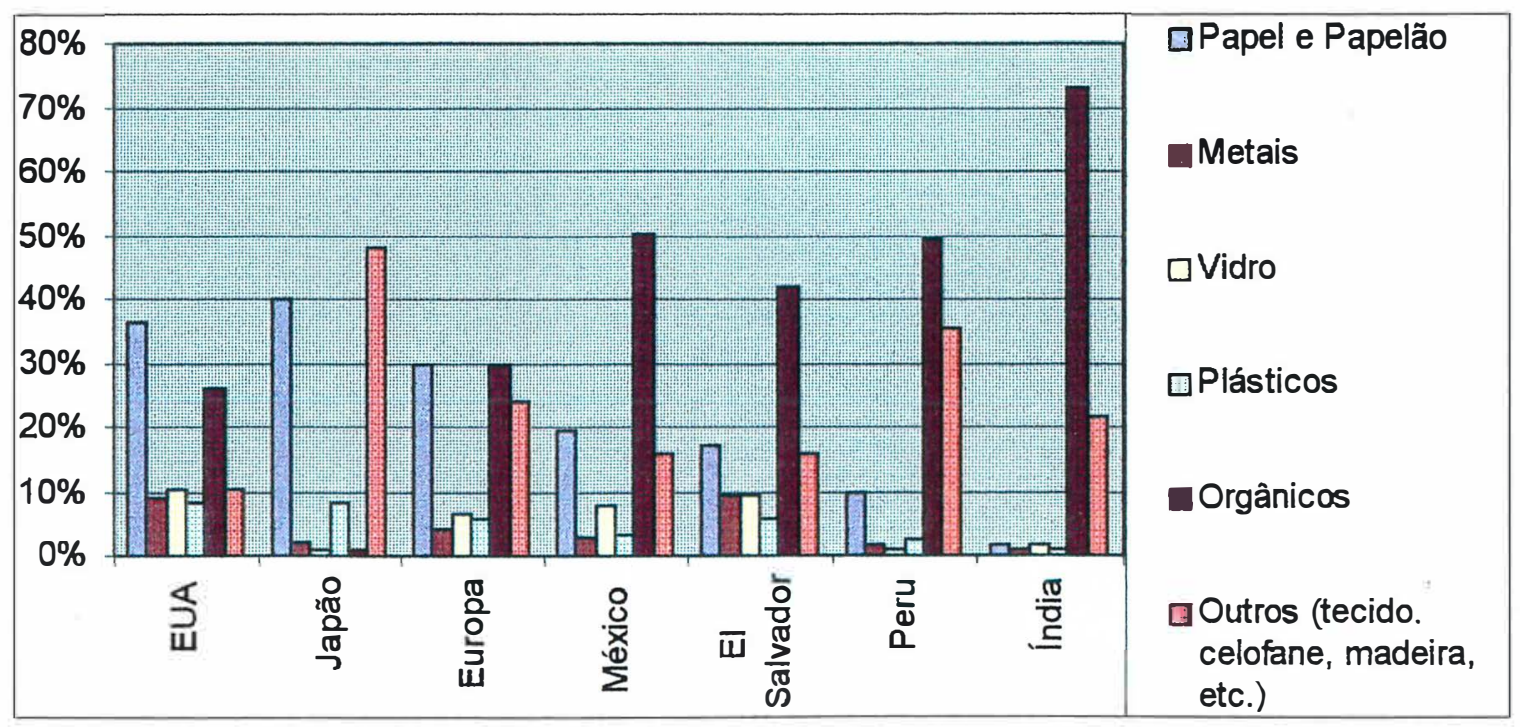

Figura 3.6 - Composição dos resíduos (\% em peso), em diversos países (Neder, 1998)

Pode-se notar pela Figura 3.6 que quanto maior o percentual de matéria orgânica no resíduo, menor o percentual dos outros materiais 
(incluem os materiais utilizados nas embalagens). Na Índia, país considerado em desenvolvimento, o resíduo é praticamente só matéria orgânica, enquanto que no Japão, país já desenvolvido, o resíduo de matéria orgânica é relativamente bem menor.

A Tabela 3.6 mostra a evolução histórica da composição dos resíduos sólidos do município de São Paulo. Esta Tabela retrata o aumento dos materiais (papel, plástico, metais e vidro) que são utilizados na fabricação de embalagem e a diminuição da matéria orgânica no lixo. Observa-se, também, que ocorre um decréscimo dos materiais vidro e metais e o aumento do percentual de plástico. A crescente utilização do plástico pode ser notada nas prateleiras do supermercado onde, antes as embalagens dos produtos eram em materiais como vidro ou metal e atualmente são de plástico.

Tabela 3.6 - Evolução Histórica da Composição (\% da massa total) dos Resíduos Sólidos gerados no Município de São Paulo entre 1927 e 1993 (Calderoni, 1998)

\begin{tabular}{l|l|l|l|l|l|l|l|l|l|l|l}
\hline \multirow{2}{*}{ componentes } & \multicolumn{10}{c}{ Período } \\
\cline { 2 - 15 } & 1927 & 1947 & 1957 & 1965 & 1969 & 1972 & 1976 & 1989 & 1990 & 1991 & 1993 \\
\hline metais & 1,7 & 2,2 & 2,2 & 2,2 & 7,8 & 4,2 & 4,0 & 3,3 & 5,3 & 3,5 & 3,2 \\
\hline $\begin{array}{l}\text { vidro } \\
\text { papel/papelão/ } \\
\text { jomal }\end{array}$ & 0,9 & 13,4 & 1,4 & 1,5 & 2,6 & 2,1 & 1,7 & 1,5 & 4,2 & 1,7 & 1,1 \\
\hline plástico & 16,7 & 16,7 & 16,8 & 29,2 & 25,9 & 21,4 & 17,0 & 29,6 & 13,9 & 14,4 \\
\hline outros & 0,0 & 0,0 & 0,0 & 0,0 & 1,9 & 4,3 & 5,0 & 7,5 & 9,0 & 11,5 & 12,1 \\
\hline matéria orgânica & 82,5 & 76,0 & 76,0 & 76,0 & 52,2 & 47,6 & 62,7 & 55,0 & 147,4 & 60,6 & 64,4 \\
\hline total & 100,0 & 99,0 & 99,1 & 99,6 & 99,9 & 88,4 & 100,0 & 84,3 & 98,5 & 98,8 & 100,0 \\
\hline \% não explicado & 0,0 & 1,0 & 0,9 & 0,4 & 0,1 & 11,6 & 0,0 & 15,8 & 1,5 & 1,2 & 0,0 \\
\hline recicláveis & 16,0 & 20,3 & 20,3 & 20,5 & 41,5 & 36,5 & 32,1 & 29,3 & 48,1 & 30,6 & 30,9 \\
\hline
\end{tabular}

As Figuras 3.7 e 3.8 fornecem as composições dos lixos, destacando os valores percentuais que cabem às embalagens cartonadas Tetra Pak, no Brasil e nos EUA. 


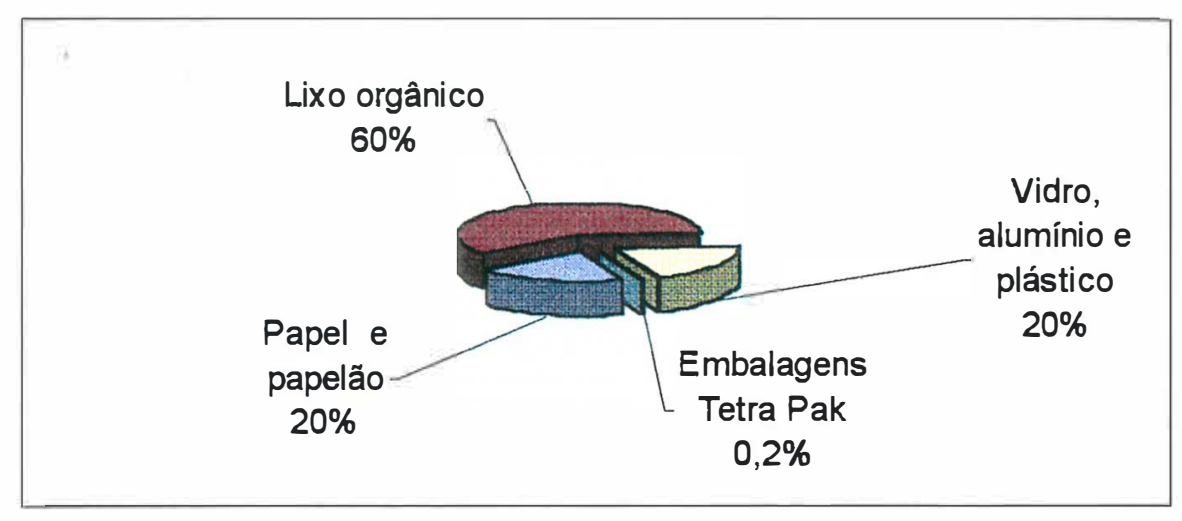

Figura 3.7 - Composição do lixo no Brasil (Pinho, 1998)

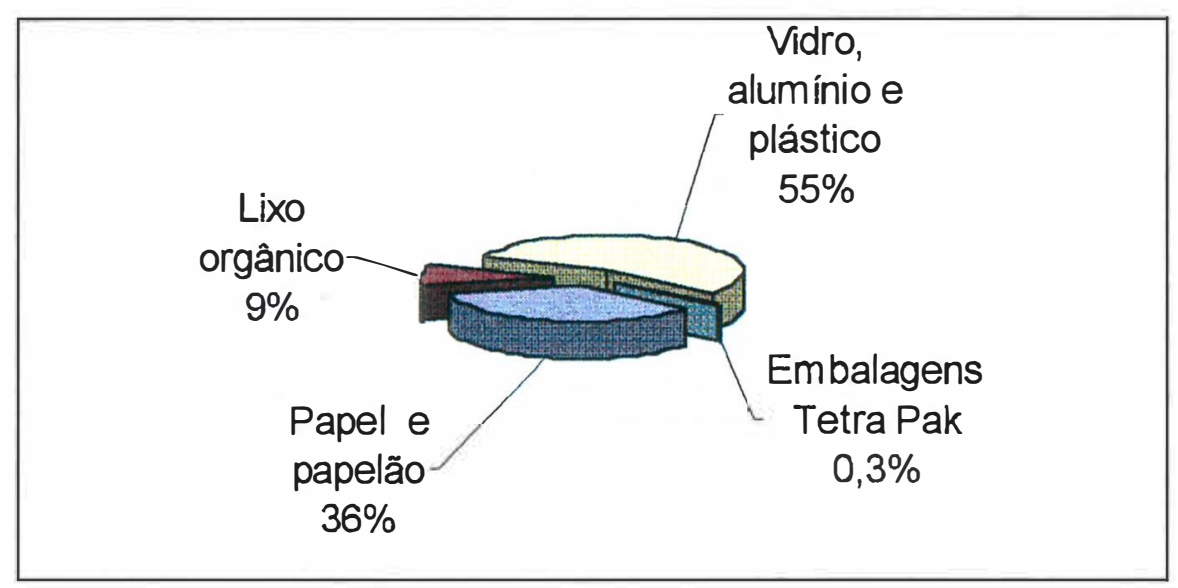

Figura 3.8 - Composição do lixo no E.U.A. (Pinho, 1998)

As premissas para o tratamento do resíduo sólido gerado pelas embalagens devem seguir a ordem: redução na fonte, reutilização, reciclagem, incineração com recuperação de energia e por fim o aterro sanitário. Este conceito é explicitado de uma forma clara na Figura 3.9.

Como dito anteriormente, o destino da maior parte do lixo no Brasil é, em primeiro lugar, o "lixão" e depois, aterros controlados ou aterro sanitário. No entanto, muitos materiais são recicláveis, como o papel, plástico, vidro, aço e alumínio. É certo que existem restrições para a reciclagem de cada 
tipo de material, por exemplo, os papéis impressos através dos processos atualmente utilizados são mais difíceis de serem reciclados, pois exigem a aplicação de processos especiais e nem sempre se consegue uma pasta de boa qualidade. No caso do vidro, a quantidade de cacos e as cores são fatores limitantes para a produção de vidros de boa qualidade.

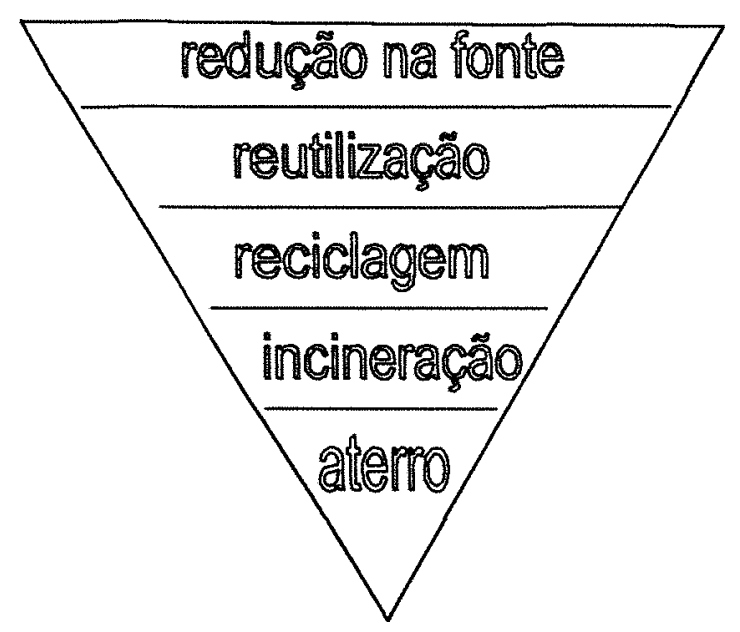

* Figura 3.9 - Ordenação para o tratamento do resíduo sólido gerado pelas embalagens

A disposição final do lixo nos municípios brasileiros, de acordo com a Pesquisa Nacional de Saneamento Básico - PNSB - 1989, realizada pelo Instituto Brasileiro de Geografia e Estatística - IBGE e editada em 1991, assim se divide (Jardim, 1995):

$76 \%$ em lixões;

$13 \%$ em aterros controlados e $10 \%$ em aterros sanitários;

$1 \%$ passam por tratamento (compostagem, reciclagem $e$ incineração) 
A alternativa de reciclagem das embalagens é a mais difundida entre a sociedade como um todo representado pelas empresas, governo e comunidade. O conceito de reciclagem, apresentado por Duston (1993) e complementado por Neves ${ }^{15}$ é expresso como sendo: um ou mais processos através dos quais qualquer produto ou material que tenha servido para os propósitos a que se destinava e que tenha sido separado do lixo e que é reintroduzido no processo produtivo, transformado-se em um novo produto, que pode assumir características iguais, semelhantes, ou diferente do anterior, bem diversas das iniciais.

* No entanto, para que a embalagem seja submetida aos processos de reciclagem, geralmente, é necessário que outras etapas ou processos tenham sido aplicados anteriormente a esta. Um destes processos, bastante em voga atualmente, é a coleta seletiva do lixo que envolve uma operação de logística para recolhimento do material apoiada por campanhas bem estruturadas de educação ambiental, seguida pela triagem do material, enfardamento e estocagem, e, por fim, do transporte para as indústrias recicladoras deste material.

Os programas de coleta seletiva no Brasil atingem, atualmente, 110 municípios brasileiros (Kudrjawzew, 1998). A Tabela 3.7 mostra o número de municípios que praticam a coleta seletiva em 1994, segundo extratos populacionais selecionados (Calderoni, 1998).

\footnotetext{
${ }^{15}$ NEVES, J. M. Comunicação pessoal, 1999.
} 
Tabela 3.7 - Brasil - Número de municipios que praticam a coleta seletiva, segundo extratos populacionais selecionados - 1994

\begin{tabular}{l|c}
\hline \multicolumn{1}{c|}{ Faixa populacional (habitantes) } & $\begin{array}{c}\mathrm{n}_{-}^{\circ} \text { de municipios com coleta } \\
\text { seletiva }\end{array}$ \\
\hline menor que 20.000 & 17 \\
\hline entre 20.001 e 50.000 & 16 \\
\hline entre 50.001 e 100.000 & 14 \\
\hline entre 100.001 e 300.000 & 17 \\
\hline entre 300.001 e 600.000 & 7 \\
\hline maior que 600.000 & 11 \\
\hline
\end{tabular}

A composição média de resíduos recicláveis coletados em cidades brasileiras pode ser observada na Tabela 3.8 (Calderoni, 1998).

Tabela 3.8 - Brasil - Composição média dos resíduos sólidos observada em programas de coleta seletiva promovidos por cidades selecionas 1992-1994

\begin{tabular}{l|c}
\hline \multicolumn{1}{c|}{ Material } & $\begin{array}{c}\text { Porcentagem do } \\
\text { peso total }\end{array}$ \\
\hline Rejeito & 8 \\
\hline caixinha Tetra Pak & 2 \\
\hline Papel/papelão & 39 \\
\hline metais ferrosos & 16 \\
\hline alumínio & 1 \\
\hline vidro & 15 \\
\hline plásticos rígidos & 12 \\
\hline plástico filme & 7 \\
\hline
\end{tabular}

Os niveis de reciclagem ou índice de reciclagem alcançados no Brasil é verificado na Tabela 3.9 (Calderoni, 1998).

Tabela 3.9 - Brasil - Nivel de reciclagem alcançado (\% da produção a partir de materiais recicláveis em relação ao total da produção)

\begin{tabular}{l|l|l|l|l|l}
\hline $\begin{array}{l}\text { Nivel de de } \\
\text { reciclagem }\end{array}$ & $\begin{array}{l}\text { Papel } \\
(1995)\end{array}$ & $\begin{array}{l}\text { Plástico } \\
(1995)\end{array}$ & $\begin{array}{l}\text { Vidro } \\
(1996)\end{array}$ & $\begin{array}{l}\text { Lata de Aço } \\
(1993)\end{array}$ & $\begin{array}{l}\text { Lata de } \\
\text { Alumínio } \\
(1996)\end{array}$ \\
\hline$(\%)$ & 32 & 12 & 35 & 18 & 70 \\
\hline
\end{tabular}


Leon (1998), compara os valores dos resíduos de diversos materiais (papel, plástico, ferro) com os de alumínio e concluí que o custo do frete para os outros materiais, com o exceção do alumínio, impossibilita a viabilidade econômica do processo de reciclagem desses materiais nas empresas em São Paulo; nos estados do Norte e Nordeste somente a instalação de mais empresas recicladoras irá melhorar os índices de reciclagem.

No caso do papel, o índice de reciclagem no Brasil é relativamente baixo se compararmos ao México, Japão e outros, conforme mostra a Tabela 3.10 (Calderoni, 1998).

No segmento de embalagens para alimentos, é bastante complicado projetar embalagens que sejam recicláveis ou biodegradáveis, porque é necessário combinar materiais para dar proteção adequada ao produto. Outro aspecto é a utilização da pasta reciclada, muitas vezes com alto indice de metais pesados (tinta de impressão), inaceitáveis para estar em contato com alimentos. A alternativa é isolar este material através da impermeabilização e complicando assim a sua reciclabilidade.

As tabelas $3.11,3.12,3.13,3.14$ e 3.15 mostram as possibilidades de processamento/reciclagem para embalagens laminadas com alumínio (IPT, /198/). 
Tabela 3.10 - Paises selecionados - A reciclagem do papel em 1990 (\% das toneladas de aparas recicladas sobre as toneladas produzidas)

\begin{tabular}{l|c|c|c}
\hline País & $\begin{array}{c}\text { Aparas recicladas } \\
(\text { mil t) }\end{array}$ & $\begin{array}{c}\text { Produção de papel } \\
\text { (mil t) }\end{array}$ & $\begin{array}{c}\text { Índice de } \\
\text { reciclagem (\%) }\end{array}$ \\
\hline Taiwan & 3.403 & 3403 & 100,0 \\
\hline Dinamarca & 267 & 335 & 79,7 \\
\hline México & 2.148 & 2871 & 74,8 \\
\hline Coréia do Sul & 3.342 & 4524 & 73,9 \\
\hline Holanda & 1820 & 2742 & 66,4 \\
\hline Espanha & 2.209 & 3445 & 64,1 \\
\hline Venezuela & 373 & 609 & 61,2 \\
\hline Grã-Bretanha & 2847 & 4824 & 59,0 \\
\hline Colômbia & 300 & 534 & 56,2 \\
\hline Índia & 1250 & 2295 & 54,5 \\
\hline Japão & 14613 & 28086 & 52,0 \\
\hline Alemanha Oc. & 6071 & 12547 & 48,4 \\
\hline França & 3295 & 7049 & 46,7 \\
\hline Indonésia & 649 & 1438 & 45,1 \\
\hline Itália & 2504 & 5601 & 44,7 \\
\hline Portugal & 339 & 781 & 43,4 \\
\hline Austrália & 841 & 2011 & 41,8 \\
\hline Áustria & 1760 & 4227 & 41,6 \\
\hline Grécia & 130 & 347 & 37,5 \\
\hline Argentina & 332 & 926 & 35,9 \\
\hline Brasil & 1479 & 4716 & 31,4 \\
\hline China & 4170 & 13719 & 30,4 \\
\hline Estados Unidos & 19769 & 71519 & 27,6 \\
\hline África do Sul & 510 & 1904 & 26,8 \\
\hline Bélgica & 265 & 1198 & 22,1 \\
\hline Canada & 1789 & 16466 & 10,9 \\
\hline & & & \\
\hline
\end{tabular}

Tabela 3.11 - Tipos de Processos por classe

\begin{tabular}{l|l|l|l}
\hline \multicolumn{1}{c|}{ Físico } & \multicolumn{1}{c|}{ Químico } & \multicolumn{1}{c}{ Físico-Químico } & Biológico \\
\hline fragmentação & úmido com solvente & pirólise & $\begin{array}{l}\text { processo } \\
\text { bacteriológico }\end{array}$ \\
\hline Criogenia & úmido com solvente/áqua & | & \\
\hline extrusão & & |hidrogenenação & \\
\hline prensagem & & |pirólise/hidrogenação & \\
\hline derretimento & | adição anódica & \\
\hline & |processo de leito fluidizado & \\
\hline
\end{tabular}


Tabela 3.12 - Processamento/reciclagem física de laminados com alumínio

\begin{tabular}{l|l|l|l|l}
\hline \hline \multicolumn{1}{c|}{ Tipo } & \multicolumn{1}{|c|}{$\begin{array}{c}\text { Estrutura do } \\
\text { Material }\end{array}$} & \multicolumn{1}{|c|}{ Resultado } & $\begin{array}{l}\text { Estado da } \\
\text { Técnica }\end{array}$ & \multicolumn{1}{|c}{ Comentários } \\
\hline $\begin{array}{l}\text { Criogenia } \\
\left(-80^{\circ} \mathrm{C}\right)\end{array}$ & Al/Plástico & Al e Plástico & Operacional & $\begin{array}{l}\text { alto consumo de } \\
\text { energia }\end{array}$ \\
\hline Fragmentação & Al/Papel & Al e Celuloses & Laboratorial & \\
\hline Extrusão & $\begin{array}{l}\text { Al/Plástico } \\
\text { Al/Plástico/Papel }\end{array}$ & $\begin{array}{l}\text { Granulados para os } \\
\text { blocos utilizados nos } \\
\text { paletes }\end{array}$ & Operacional & $\begin{array}{l}\text { Produtos de baixo } \\
\text { padrão } \\
\text { qualidade }\end{array}$ \\
\hline Prensagem & $\begin{array}{l}\text { Al-Cartão (Brick- } \\
\text { Pack) }\end{array}$ & $\begin{array}{l}\text { produtos de cartão } \\
\text { prensado }\end{array}$ & Piloto & \\
\hline Derretimento & & Lingotes de Al & & \\
\hline \hline
\end{tabular}

Tabela 3.13 - Processamento/reciclagem química de laminados com alumínio

\begin{tabular}{l|l|l|l|l}
\hline \hline Tipo & $\begin{array}{l}\text { Estrutura do } \\
\text { Material }\end{array}$ & Resultado & Estado da Técnica & Comentários \\
\hline Solvente & Al/PE/PVC & Al e Polímero & Piloto & $\begin{array}{l}\text { não é adequado } \\
\text { para laminados de } \\
\text { PET }\end{array}$ \\
\hline Água e solvente & $\begin{array}{l}\text { Al/Cartão } \\
\text { Al/Papel }\end{array}$ & Al e Celulose & Operacional & $\begin{array}{l}\text { rendimento pobre } \\
\text { para o Al possui a }\end{array}$ \\
\hline Agua e solvente & Brick-Pack & Al, PE e Celulose & Piloto & $\begin{array}{l}\text { RWE patente estendida a } \\
\text { patenta operação } \\
\text { esta }\end{array}$ \\
\hline Ácido & Al/Plástico & $\begin{array}{l}\text { Cloreto de Al ou } \\
\text { Sulfato de Al e } \\
\text { Plásticos }\end{array}$ & Piloto & não é adequado \\
\hline \hline
\end{tabular}

Tabela 3.14 - Processamento/reciclagem físico-química de laminados com aluminio

\begin{tabular}{|c|c|c|c|c|}
\hline Tipo & $\begin{array}{c}\text { Estrutura do } \\
\text { Material }\end{array}$ & Resultado & $\begin{array}{l}\text { Estado da } \\
\text { Técnica }\end{array}$ & Comentários \\
\hline Pirólise & $\begin{array}{l}\text { Al/Plástico } \\
\text { Al/Papel } \\
\text { Al/Plástico/Papel }\end{array}$ & $\begin{array}{l}\text { Al e granulados } \\
\text { da degradação } \\
\text { de polímeros } \\
\text { orgânicos }\end{array}$ & Operacional & \begin{tabular}{lr} 
deve-se & \multicolumn{2}{c}{ analisar do } \\
ponto de & vista \\
econômico & e \\
ecológico & \\
\end{tabular} \\
\hline $\begin{array}{l}\text { Hidrólise } \\
\text { (Glicólise } \\
\text { Alcóolise) }\end{array}$ & $\begin{array}{l}\text { Plástico } \\
\text { (poliuretano) }\end{array}$ & $\begin{array}{ll}\text { poliol } & \mathrm{e} \\
\text { isocianato } & \end{array}$ & Piloto & \\
\hline Hidrogenação & Al/Polímero & $\begin{array}{l}\text { hidrocarbonetos } \\
\text { e Al }\end{array}$ & Laboratorial & $\begin{array}{l}\text { em termos químicos } \\
\text { uma boa tecnologia }\end{array}$ \\
\hline Leito Fluidizado & $\begin{array}{l}\text { Al/Plástico } \\
\text { Al/Papel } \\
\text { Al/Plástico/Papel }\end{array}$ & Al e Carbono & Piloto & $\begin{array}{l}\text { A Alcan possui } 0 \\
\text { know how }\end{array}$ \\
\hline
\end{tabular}


Tabela 3.15 - Processamento bacteriológico

\begin{tabular}{|c|c|c|c|}
\hline $\begin{array}{ll}\text { Estrutura } & \text { do } \\
\text { material } & \\
\end{array}$ & Resultado & Estado da Técnica & Comentários \\
\hline Al/Cartão & Celulose e Al & $\begin{array}{l}\text { Não há } \\
\text { informações }\end{array}$ & 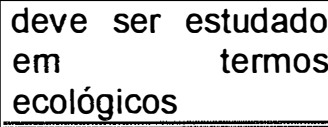 \\
\hline
\end{tabular}

Segundo Pinho (1998), o processo de reciclagem da embalagem multicamada (papel, plástico e alumínio) desenvolvido pela Tetra Pak Brasil é denominado "hidrapulper". O equipamento utilizado neste processo opera com $15 \%$ de água, sem a adição de qualquer composto químico para acelerar a hidratação das fibras. No equipamento ocorre uma agitação de 35 minutos que separa o polietileno e alumínio do papel. As fibras obtidas por este processo podem ser utilizadas para a fabricação de papeltoalha, caixas de papelão ondulado e outros.

O polietileno e o alumínio, de acordo com D'Alessio (1998), podem ser reaproveitados de três maneiras diferentes: recuperação de energia através da incineração em caldeiras de biomassa ou fornos de pirólise e através de processos de transformação de plástico (extrusão e injeção) para obtenção de peças de baixa resistência mecânica. A Figura 3.10 mostra as etapas deste processo.

No Brasil, relata Marques (1998), este processo submeteu a reciclagem apenas 500 toneladas de embalagens Tetra Brik de uma produção de 4 bilhões de unidades em 1997. Entretanto, na Alemanha, o índice de reciclagem foi de $65 \%$ nesse mesmo ano, equivalente a 124 mil toneladas de embalagem multicamada. 


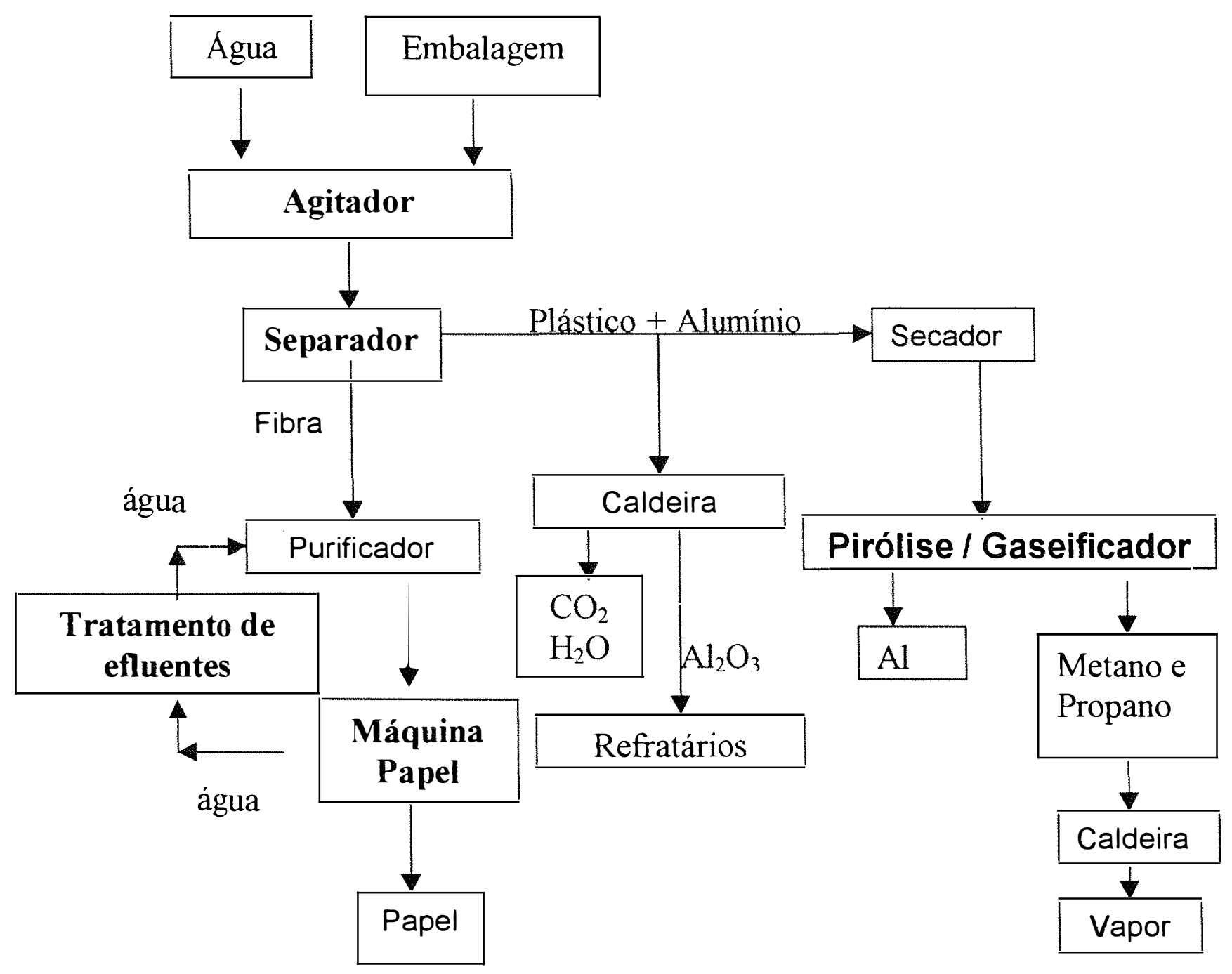

Figura 3.10 - Processo de reciclagem de embalagens Tetra Pak

No Brasil, as aparas são praticamente utilizadas na fabricação de papelão ondulado, principalmente o miolo (parte interna do papelão que não necessita de papel de boa qualidade para a fabricação), conforme mostra a 
Tabela 3.16 (Calderoni, 1998). Isto ocorre devido a perda de parte das propriedades do papel, após cada utilização.

Tabela 3.16 - Brasil - Consumo de aparas para produção de papel em 1995

\begin{tabular}{l|c|c}
\hline \multicolumn{1}{c|}{ Tipos } & em mil t & $\%$ \\
\hline Hollerith & 6,8 & 0,4 \\
\hline Branca I & 54,0 & 2,9 \\
\hline Branca II & 91,2 & 5,0 \\
\hline Branca III & 21,0 & 1,1 \\
\hline Branca IV & 72,6 & 3,9 \\
\hline Branca V & 0,1 & 0,0 \\
\hline Kraft I & 35,3 & 1,9 \\
\hline Kraft II & 41,1 & 2,2 \\
\hline Kraft III & 7,2 & 0,4 \\
\hline Aparas Paraná & 26,2 & 1,4 \\
\hline Jornais & 110,5 & 6,0 \\
\hline Cartolina I & 58,6 & 3,2 \\
\hline Cartolina II & 18,5 & 1,0 \\
\hline Cartolina III & 2,2 & 0,1 \\
\hline Ondulado I & 321,4 & 17,5 \\
\hline Ondulado II & 487,9 & 26,5 \\
\hline Ondulado III & 192,7 & 10,5 \\
\hline Revistas & 10,2 & 0,6 \\
\hline Misto I & 114,9 & 6,2 \\
\hline Misto II & 67,2 & 3,7 \\
\hline Misto III & 36,0 & 2,0 \\
\hline Tipografia & 64,7 & 3,5 \\
\hline TOTAL & 1840,1 & 100,0 \\
\hline
\end{tabular}

Um estudo realizado por Koning e Godshall (1975), avaliou os efeitos da reciclagem repetida no desempenho no papelão e nas caixas de papelão ondulado. Neste estudo, Koning e Godshall (1975) observaram que o desempenho no papelão diminui, quando $100 \%$ de fibra reciclada é utilizada e que a maior perda de resistência ocorre entre o material virgem e a primeira reciclagem em comparação com reciclagens subsequentes. 
Koning \& Godshall (1975) relatam que as reciclagens repetidas causam pior drenagem na máquina de papel e diminui a maquinabilidade da onduladeira. Entretanto, as quebras na linha de produção são mais em função da umidade do material do que da reciclagem.

A resistência a compressão da caixa de papelão ondulado é uma propriedade requerida para o empilhamento seguro. No estudo de Koning e Godshall, esta propriedade foi reduzida em $10 \%$ para caixas baixas. As caixas altas apresentaram redução significativa de $24 \%$ desta propriedade.

Por outro lado, segundo Neves (1996), as caixas de papelão ondulado que são fabricadas com pastas de alto rendimento com a reciclagem podem ter sua qualidade melhorada. Estas pastas possuem praticamente todos os componentes químicos originalmente presentes na madeira e o resultado de sucessivas reciclagens é o aumento do potencial de ligação entre as fibras, o que, consequentemente, aumenta a rigidez ou resistência a flexão do papelão.

No caso da reciclagem sucessiva de cartões, Neves (1996), comenta que a reciclagem pode contribuir para o aumento de sua rigidez, mas traz diminuição da sua flexibilidade, redução das ligações fibra-fibra e consequentemente, diminuição das resistências ao estouro, à tração e à dobras duplas, diminuindo também a densidade. Em contra partida, há aumento na resistência ao rasgo e na opacidade.

A embalagem multicamada utilizada no acondicionamento de leite há cerca de 20 anos atrás alcançava a participação no mercado, somente 0,8\% (DISPARADA, 1998). Em 1997, a sua participação no mercado de leite fluido embalado foi de $48,25 \%$, contra $40,2 \%$ em 1996. A Tabela 3.17 mostra a divisão do mercado de leite embalado. Outros produtos, tais como, suco, 
molhos, doces e outros têm sofrido a substituição de suas embalagens pela embalagem multicamada, conforme indicado na Tabela 3.18.

Tabela 3.17 - Mercado de leite no Brasil em 1996 (Senhor, 1998)

\begin{tabular}{l|c|c}
\hline Tipo de leite & $\begin{array}{l}\text { Consumo } \\
\text { (bilhões de litros) }\end{array}$ & $\begin{array}{l}\text { Participação no } \\
\text { volume de leite (\%) }\end{array}$ \\
\hline A granel & 9,5 & -- \\
\hline Longa Vida (UHT) & 1,7 & 10,7 \\
\hline Pasteurizado & --- & 15,9 \\
\hline Em pó & -- & 11,4 \\
\hline Produção total & \multicolumn{2}{|c}{19 bilhões de litros } \\
\hline Consumo per capita & \multicolumn{2}{|c}{ 124 litros } \\
\hline
\end{tabular}

Tabela 3.18 - Evolução do consumo de embalagens "caixinhas" em milhões de unidades (Consumidor, 1998)

\begin{tabular}{l|c|c|c}
\hline \multicolumn{1}{c|}{ produto } & 1995 & 1996 & 1997 \\
\hline chá & 37 & 34 & 35 \\
\hline creme de leite & 114 & 144 & 157 \\
\hline iogurtes e sobremesas & 47 & 54 & 75 \\
\hline leite & 2467 & 3396 & 3975 \\
\hline leite condensado & 37 & 66 & 74 \\
\hline maionese & 44 & 33 & 37 \\
\hline sucos de fruta & 210 & 182 & 213 \\
\hline molho de tomate & 295 & 272 & 296 \\
\hline
\end{tabular}

A importância da avaliação da degradabilidade destas embalagens no meio ambiente é relevante, visto a crescente utilização deste tipo de embalagem e às dificuldades de sua reciclagem ou reutilização dos materiais que dela são recuperados.

\subsection{2 "Lixão", aterro controlado e aterro sanitário}

Jardim et al. (1995) descreve que o "lixão" é uma forma inadequada de disposição final de resíduos sólidos, que se caracteriza pela simples descarga sobre o solo, sem medidas de proteção ao meio ambiente ou 
saúde pública. É o mesmo que descarga de resíduos a céu aberto. As características da disposição na forma de "lixão" são:

- ausência de controle sobre o tipo, o volume e a periculosidade dos resíduos despejados no local;

- permanência dos resíduos a céu aberto; e

- ausência de controle de entrada e saída de animais e pessoas.

No caso do aterro controlado, Jardim et al. (1995) relatam que, é uma técnica de disposição de resíduos sólidos urbanos no solo, sem causar danos ou riscos à saúde pública e à sua segurança, minimizando os impactos ambientais.

Para este tipo de aterro são utilizados princípios de engenharia para confinar os resíduos sólidos, cobrindo-os com uma camada de material inerte na conclusão de cada jornada de trabalho, conforme descreve a norma ABNT, NBR-8849/85.

Esta forma de disposição, Jardim et al. (1995) afirmam que produz uma poluição localizada, pois similarmente ao aterro sanitário, a extensão da área de disposição é minimizada. Entretanto, não dispõe de impermeabilização de base (comprometendo a qualidade das águas subterrâneas), nem sistemas de tratamento de chorume ou de dispersão dos gases gerados.

O aterro sanitário, conforme norma ABNT NBR-10703/89 Terminologia - Degradação do Solo, é uma "forma de disposição final de resíduos sólidos urbanos no solo, através de confinamento em camadas 
cobertas com material inerte, geralmente solo, segundo normas operacionais específicas, de modo a evitar danos ou riscos à saúde pública e à segurança, minimizando os impactos ambientais". A Figura 3.8 apresenta um desenho de um aterro sanitário.

Benvenuto (1994) sugere três tipos de concepção de aterro sanitário: anaeróbica, semi-aeróbia e biológica. A primeira alternativa, a anaeróbica, têm como desvantagens a geração de gás metano e gás carbônico, chorume com altos índices de demanda bioquímica de oxigênio (DBO) e demanda química de oxigênio (DQO), a proporção de gás e chorume prejudicam a estabilidade mecânica do aterro e é necessário longo tempo para inertização.

A segunda alternativa, a semi-aeróbica, já apresenta vantagens com relação ao primeiro, pois é rápida a decomposição do lixo e estabilização, o chorume apresenta índices menores de DBO e DQO e a produção de gases perigosos é reduzida. A terceira alternativa, biológica, acelera a inertização através de inoculações que provocam reações com metais pesados e possibilitam a segregação desses materiais.

\subsubsection{Chorume}

Existem duas normas da ABNT - Associação Brasileira de Normas Técnicas que definem o chorume.

O chorume é um "líquido produzido pela decomposição de matéria orgânica contida nos resíduos sólidos, particularmente quando dispostos em aterros de lixo. Apresenta elevado potencial poluidor e tem como 
características a cor negra e o mau cheiro. O mesmo que "sumeiro", conforme definição da NBR 10703/89 - Terminologia - Degradação do Solo; ou

"Líquido, produzido pela decomposição de substâncias contidas nos resíduos sólidos, que tem como características a cor escura, o mau cheiro e a elevada DBO (Demanda Bioquímica de Oxigênio)", conforme NBR 8419/84 - Procedimento - Apresentação de Projetos de Aterros Sanitários de Resíduos Sólidos Urbanos.

No entanto, Abreu (1995) relata que pesquisas têm demonstrado a possibilidade de aproveitamento do chorume para fabricação de álcool, açúcares e etanol.

O chorume proveniente de um aterro ou lixão apresenta características físico-químicas e biológicas diferentes quando comparado a outros. Isto ocorre porque vários fatores podem influenciar nessas características. Gomes et al. (1998), relata que as razões para as grandes variações nos resultados das análises dos chorumes provenientes de diferentes aterros sanitários ou lixões estão relacionadas às características da população geradora dos resíduos (nivel e características de vida sócioeconômico-culturais), topografia e geologia do local do tratamento e/ ou destino final do lixo, formas de coleta dos resíduos, e ainda, às características hidrológicas e climáticas da região.

\subsubsection{Resíduos sólidos no aterro sanitário}

Erwin \& Heaerly (1990) relatam que o aterro sanitário é coberto com barro quando é fechado, para restringir a água da chuva de infiltrar 
através do resíduo, levando poluentes para as águas subterrâneas. Estes procedimentos criam um ambiente seco e de baixa oxigenação. Dessa forma, os mecanismos de degradação aeróbicos não funcionam tornando a degradação muito lenta.

Escavações de aterros revelaram, segundo Erwin \& Heaerly (1990), que jornais com vinte anos de idade ainda podem ser lidos e cenouras que ainda estão alaranjadas quando partidas. O aterro sanitário, quando feito apropriadamente, é um sepultamento, não uma compostagem. Isto ocorre porque o mais rápido mecanismo de degradação, o aeróbico, não funciona.

Desde 1973, um "arqueólogo" da Universidade do Arizona e sua equipe, relata Rathje (1992), estudam o conteúdo dos aterros sanitários norte americanos, realizando escavações nos mesmos. A pesquisa vem mostrando os componentes do lixo doméstico do país e a real eficiência dos aterros quanto à degradabilidade dos materiais orgânicos, pois já foram coletadas várias amostras de alimentos e papéis, enterrados há mais de 10 anos e ainda continuam intactos.

Briston \& Katan (1974) comentam que em aterros, os plásticos não dão origem ou produzem gases por decomposição, ou seja, isto é um problema da decomposição do lixo orgânico. Também, observaram que a proporção de plástico presente nos aterros é relativamente pequena quando comparada `a de outros materiais e `a do lixo orgânico. Entretanto, quando ele aumenta acima de uma certo nível, ele pode apresentar um problema na modificação da densidade do aterro e torná-lo elástico. Briston \& Katan (1974) sugerem que para solucionar este problema pode-se fragmentar o plástico. 
Por outro lado, Briston \& Katan (1974) comentam que os materiais plásticos poderiam, eventualmente, ser decompostos por bactérias anaeróbicas, entretanto os arqueologistas estudaram que, materiais aparentemente degradáveis, como a madeira, podem sobreviver por muito tempo quando parcialmente queimada.

Finalmente, Briston \& Katan (1974) concluem que, nossa ignorância do destino dos plásticos é igual 'a que existe para os outros materiais, exceto o lixo orgânico, e não existe razão para supor que os plásticos causem mais problemas que os outros materiais como metais, vidros e papéis.

\subsubsection{Degradação dos materiais de embalagem}

\subsubsection{Plástico}

Os polímeros deterioram através de uma seqüência complexa de reações químicas. Usualmente, ocorrem mudanças significativas no peso molecular, resultantes da quebra de cadeia ou quebra de ligações. A deterioração pode acontecer também sem a mudança do tamanho da molécula do polímero.

As ligações químicas nos polímeros são quebradas, formando radicais livres, pela ação do calor, radiação ionizante, fadiga mecânica e reações químicas. Van \& Lawrence (1970) relatam que a temperatura na qual os polimeros se tornam altamente suscetiveis a reações químicas corresponde à temperatura na qual se perde a resistência mecânica. Essa temperatura, segundo eles, está abaixo do ponto de fusão dos polímeros lineares e corresponde ao começo de degradação dos polímeros tridimensionais. 
Griffin (1976) e Swern (1961) relatam que a degradação por oxidação de polímeros pode ser causada pelo ataque de peróxidos na cadeia polimérica como, por exemplo, a do polietileno. Esta oxidação pode ser observada através de espectrofotometria no infravermelho, onde grupos carbonila serão incorporados na cadeia polimérica.

No estudo realizado por Griffin (1976), foi observado que o polietileno pode sofrer oxidação quando exposto ao chorume, devido a possibilidade deste apresentar ácidos graxos insaturados, que poderiam gerar peróxidos autoxidantes. Neste estudo, amostras do filme degradado foram submetidas a análise por espectrofotometria no infravermelho. O espectro revelou alterações consideráveis em relação a um típico polietileno (Figura 3.11). Notam-se três novos picos, um deles (a) claramente associado com a presença de grupo carbonila.

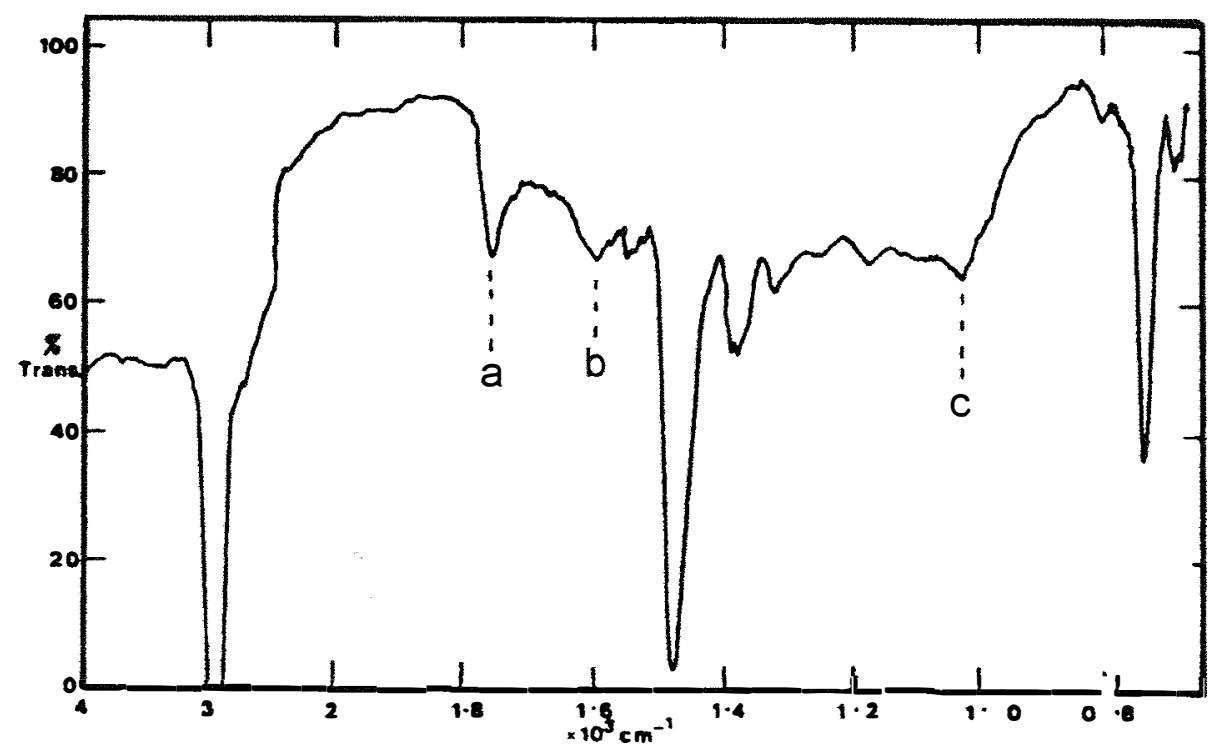

Figura 3.11 - Espectro de polietileno exposto à degradação em composto orgânico. 
Kelen (1983, p.24) relata que os produtos de oxidação dos polímeros são voláteis e somente uma parte deles formam na cadeia polimérica grupos carbonilas, carboxilas, hidroxilas, ou hidroperóxidos.

Shnabel (1981, p.197) comenta que os produtos voláteis formados da oxidação do polietileno e polipropileno podem ser, por exemplo, ácido fórmico, ácido acético e acetona.

Briston \& Katan (1974) relatam que de um modo geral os plásticos são muito resistentes a ataques não muito fortes de vapores do meio ambiente, no entanto, a permeação destes vapores pode ocorrer mas isto não pode dizer que se constitua num ataque aos plásticos. Os termoplásticos olefínicos e os termofixos são resistentes aos vapores de água, e sempre plásticos com grupos ativos, como as poliamidas, absorvem água em quantidades significativas.

Comentam ainda Briston \& Katan (1974) que, acima de um determinado período, o oxigênio ataca muitos plásticos, especialmente se simultaneamente expostos ao calor ou radiação ultra violeta (u.v.); o efeito causado pelo ozônio é mais rápido. Nos piores casos, no entanto, estes efeitos são raros na prática.

O efeito do dióxido de carbono, de acordo com Briston \& Katan (1974) é normalmente negligenciado, e os cloretos (os quais podem ser encontrados em equipamentos de processo) não têm sérios efeitos sobre termoplásticos comuns. Entretanto, outro vapor qualquer deve ser considerado nos seus méritos individuais. 
Quanto aos ataques microbiológico aeróbico e de ratos, Briston \& Katan (1974) relatam que, os plásticos são muito resistentes e podem ser comparados aos metais neste aspecto. A principal exceção é o plastificante do cloreto de polivinila (PVC), o qual é vulnerável sob condições adequadas. Neste caso, o ataque ocorre sobre as ligações da cadeia polimérica, causando a evolução de cloreto de hidrogênio $(\mathrm{HCl})$, o qual catalisa a degradação. $\mathrm{O}$ efeito é percebido primeiramente pela aparência esbranquiçada, seguida de uma coloração vermelho/rosa no plástico. O odor do cloreto de hidrogênio pode ser detectado.

Nos dias de hoje, de acordo com Briston \& Katan (1974), isto é raro porque os plastificantes utilizados têm maior resistência e adiciona-se agentes bactericidas ao PVC. No caso do poliestireno, o comportamento com o crescimento de fungos é a ocorrência de uma descoloração cinza/negro, após longo período sob condições adequadas. Os termofixos são imunes aos ataque microbiológicos.

Potts (1978) mediram a biodegradabilidade de muitos aditivos normalmente usados nas formulações de plásticos. O método ASTM-D-192463 - Recommended practice for determining resistance of synthetic polimeric materials to fungi foi utilizado. Os resultados demonstraram que muitos desse aditivos foram digeridos por microorganismos. Este fato, mostra a necessidade de uma investigação sobre a suscetibilidade de polímeros sintéticos serem atacados por microorganismos.

A degradação por radiação ultravioleta (u.v.), em polímeros como o polietileno e polipropileno, consiste da quebra da cadeia polimérica, acompanhada pela oxidação. Isto leva a perda de resistência mecânica e deterioração da superfície aparente coo plástico. A adição de pigmentos opacos 
pode ser uma barreira ao efeito da radiação, e poderá concentrar este efeito de degradação às camadas mais extremas da superfície, protegendo o material internamente.

O negro de fumo, segundo Briston \& Katan (1974), é o pigmento mais efetivo para proteção do polímero aos raios ultravioletas (U.v.), no entanto o uso deste é freqüentemente descartado por requisitos de marketing, devido a aparência. No caso de saches para leite ele tem sido usado na forma de laminado de polietileno, sendo a camada externa branca e a interna preta. Existem outros produtos, não pigmentos opacos, mas estabilizantes de u.v., os quais funcionam através da absorção da região de u.v. do espectro solar, ou inibem as reações nas cadeias poliméricas iniciadas pelou.v.

Hanlon (1971, p.8-43), relata que, a luz com menor comprimento de onda causam mais danos aos plásticos, principalmente, na parte do espectro de luz ultravioleta entre (300 e 400) nm.

Kelen (1983, p.137-138), determinou, através da energia de dissociação da ligação, que o polietileno é mais sensível quando exposto a $300 \mathrm{~nm}$ de comprimento de onda do espectro de luz ultravioleta.

Müller et al. (1993), avaliaram a influência da taxa de radiação solar sobre a durabilidade de filmes agrícolas de polietileno durante um período de vinte e um meses na cidade de Triunfo no Brasil. A comparação foi realizada entre dois tipos de espessuras $(100 \mu$ e $150 \mu)$ de filme e onze formulações de estabilizantes à luz. O ensaio de resistência mecânica foi estabelecido como critério de análise de fotodegradação, ou seja, quando $50 \%$ da sua resistência à tração original estivesse comprometida. $O$ estabilizante à 
luz Hals (Hindered Amine Light Stabilizers) são compostos de aminas estericamente bloqueadas, que inibem a degradação através da captura de radicais livres. Este composto na concentração de 0,40\% mostrou-se mais eficaz para manter as propriedades mecânicas destes filmes.

Briston \& Katan (1974) verificaram que para os materiais plásticos degradarem no meio ambiente, é necessário a interação de entidades largamente disponiveis, com produção de energia. As quatro maiores entidades são: microorganismos, oxigênio, radiação e água. Os efeitos destas entidades em conjunto é conhecido como intemperismo. A Tabela 3.19 mostra a suscetibilidade de alguns plásticos a o intemperismo.

Tabela 3.19 - Suscetibilidade dos plásticos às intempéries

\begin{tabular}{c|c}
\hline \hline Plásticos & $\begin{array}{c}\text { Suscetibilidade dos plásticos às intempéries } \\
\text { (sol, chuva e vento) }\end{array}$ \\
\hline Celulósicos & Muito alta \\
\hline Nylons & Alta \\
\hline Polipropileno & Alta \\
\hline Polietileno de Alta Densidade & Alta \\
\hline Poliestireno & Moderadamente alta \\
\hline PVC & Média \\
\hline Polietileno de Baixa & Moderadamente baixa \\
Densidade & Moderadamente baixa \\
\hline Policarbonato & Moderadamente baixa \\
\hline Polietileno Tereftalato (PET) & Baixa \\
\hline A maioria dos Termofixos & Muito baixa \\
\hline Polimetilmetacrilato & Politetrafluoretileno \\
\hline \hline
\end{tabular}

Shanabel (1981, p.210) relata que muitas investigações têm sido realizadas para avaliar o efeito do ar poluído em polímeros que serão expostos por longo período em locais abertos. Principalmente, o comportamento de alguns polímeros quando expostos a atmosferas que contenham simultaneamente dióxido de nitrogênio $\left(\mathrm{NO}_{2}\right)$, dióxido de enxofre 
$\left(\mathrm{SO}_{2}\right)$ e oxigênio, onde também é estudada a influência da radiação ultravioleta. O mecanismo da reação do $\mathrm{NO}_{2}$, relatado por ele, com polietileno e poliestireno está apresentado abaixo, onde $\mathrm{P}$ indica o polímero:

- Extração do hidrogênio

$$
\mathrm{PH}+\mathrm{NO}_{2} \rightarrow \mathrm{P} \bullet+\mathrm{HNO}_{2}
$$

- Formação de grupos nitrados por adição

$$
\mathrm{P} \bullet+\mathrm{NO}_{2} \rightarrow \mathrm{PNO}_{2}
$$

- Formação de nitrocompostos

$$
\begin{aligned}
& \mathrm{P} \bullet+\mathrm{NO}_{2} \rightarrow \mathrm{P}-\mathrm{O}-\mathrm{N}=\mathrm{O} \\
& \mathrm{PO} \bullet+\mathrm{NO}_{2} \rightarrow \mathrm{PONO}_{2}
\end{aligned}
$$

- Ruptura da ligação O-N

$$
\mathrm{PONO} \rightarrow \mathrm{PO} \bullet+\mathrm{NO}
$$

- Clivagem da cadeia principal

$$
\mathrm{PO} \bullet \sim \mathrm{C}=\mathrm{O}+\bullet \mathrm{CH}_{2} \sim
$$

- Formação de grupos hidroxilas

$$
\mathrm{PO} \bullet+\mathrm{PH} \rightarrow \mathrm{POH}+\mathrm{P} \bullet
$$

\subsubsection{Alumínio}

A degradação do alumínio pode ser atribuída ao fato de ser observada a presença de corrosão com a perda de massa ou da espessura do material. 
Fontana (1987) e Deltombe et al (1974) relatam que dentre os meios que normalmente causam corrosão no alumínio destacam-se aqueles contendo cloretos e com pH menor que 4 e maior que 9. Fontana (1987) observou que a corrosão ocorrida nessas faixas de $\mathrm{pH}$ são do tipo uniforme e em meios contendo cloretos a corrosão é localizado do tipo pite.

Chaves et al. (1980) observaram que a presença de bactérias anaeróbicas redutoras de sulfato, encontradas no chorume, podem também contribuir para uma corrosão do tipo pite.

Videla (1993), relata que as bactérias redutoras de sulfatos correspondem ao gênero Desulfovibrio e Desulfotomaculum. Sua forma é alargada (curva, sigmóide, ou eventualmente espiralada). Suas dimensões são de aproximadamente de 0,5 - 1,0 mícron por 3,0-5,0 mícrons e conseguem mobilizar-se mediante um flagelo polar. A temperatura ótima de desenvolvimento se encontra entre $25^{\circ} \mathrm{C}$ e $44^{\circ} \mathrm{C}$ e o pH entre 5,5 e $9 \mathrm{com}$ um ótimo de 7,2. Os produtos de corrosão destas bactérias podem ser 0 ácido sulfídrico ou sulfetos e o ambiente podem ser efluentes, lodos, solos, água do mar ou rio.

Videla (1993) comenta ainda que os mecanismos gerais de corrosão são:

- Produção metabótica de substâncias corrosivas;

- Criação de situações de aeração diferencial com o estabelecimento de céltulas de concentração na superfície metálica;

- Participação direta do microrganismo na reação que conduz ao processo de corrosão;

- Destruição de pelícutas protetoras sobre o metal. 


\subsubsection{Papel}

D'Almeida (1988, p.61) relata que a degradação da celulose ocorre quando é constatada a cisão da ligação 1,4-glucosídica da molécula, ou seja, a cisão da ligação entre dois monômeros de glucose.

D'Almeida (1988, p.61) comenta ainda que, a degradação produz moléculas com grau de polimerização menor, afetando a viscosidade e resistência mecânica da celulose.

Os tipos de degradação da celulose podem ser agrupados nas seguintes classes (id. Ibid., p.61-67):

- Degradação hidrolítica - pode ocorrer em meio ácido ou básico. Podendo ser do tipo homogênea que gera como produto a D-glucose ou heterogênea que mantém a estrutura fibrosa.

- Degradação oxidativa - esta introduz grupos carbonilas e carboxilas em várias posições das glucoses da cadeia de celulose. Em soluções ácidas, a oxidação produz oxiceluloses $^{16}$ redutoras (alto conteúdo de grupos carbonilas) e em soluções básicas, oxiceluloses ácidas (alto conteúdo de grupos carboxilas). Entretanto, a maioria das celuloses oxidadas contém grupos aldeídicos, cetônicos e carboxílicos. Existe, também a auto-oxidação da celulose por oxigênio molecular, na presença de álcali, utilizada para produção do raiom e celofane.

\footnotetext{
${ }^{16}$ Oxicelulose $=$ celulose oxidada
} 
- Degradação microbiológica - consiste numa hidrólise enzimática catalisada pela celulase, que é uma enzima produzida amplamente por fungos e bactérias. Ocorre a perda da resistência da celulose, mas não é acompanhada por uma grande diminuição de massa e do grau de polimerização da celulose.

- Outros tipos de degradação - degradação pela luz e por efeito térmico. No primeiro caso, a degradação ocorre na faixa do ultravioleta e, no segundo, acima de $140^{\circ} \mathrm{C}$, estas reações são aceleradas na presença de ar, umidade e acidez residual.

Yambrach \& Penet, em 1993, obtiveram, em laboratório, uma efetiva redução do volume de papel, papéis revestidos e produtos laminados com papel em produtos descartados. No processo deles, adiciona-se água com agitação, desta forma as fibras ficam mais expostas a ação enzimática, facilitando a quebra das cadeias de celulose. Os níveis de glicose medidos durante o processo indicaram uma ação efetiva da enzima.

Yambrach \& Penet (1993) relatam que os mecanismos de quebra de celulose são os mesmos empregados pelos fungos em meio natural. As enzimas atacam as ligações moleculares encurtando a uma estrutura de glucose, através de uma reação de. hidrólise da celulose catalisada pela Cytolase ${ }^{\circledR}$, uma enzima produzida pela seleção das linhagem da Aspergillus niger e do Trichoderma longibrachiatum (formalmente $T$. reesi). Esta reação pode dar uma variedade de produtos com diferentes comprimentos da cadeia molecular dependendo do tempo de duração da reação e dos produtos finais desejados. 
Yambrach \& Penet (1993) comentam ainda que, esta quebra da celulose está bem documentada na literatura há anos, no entanto, trabalhos recentes têm o objetivo num microorganismo, em enzimas e seus produtos particulares. Estudos têm identificado os microorganismos que são particularmente efetivos na quebra da celulose em unidades de glicose.

A pesquisa de Yambrach \& Penet (1993) foi capaz de identificar enzimas secretadas pelos microorganismos que na maioria produziam a quebra da celulose.

Sihtola \& Fogelberg (1955), mediram a degradação da celulose pela ação da luz ultravioleta. Foram encontrados resultados que evidenciam a degradação pelo o efeito da luz ultravioleta na celulose, através do decréscimo do DP (grau de polimerização). A degradação pelo efeito da luz ultravioleta não parece estar limitada a qualquer comprimento de onda a partir de $250 \mathrm{~nm}$ (2500A), sendo mais intensa quanto mais curto for este comprimento.

\subsubsection{Estudos de degradabilidade de materiais}

A decomposição biológica de polímeros orgânicos, de acordo com Potts (1978), é geralmente estudada pela determinação de: (a) produção de dióxido de carbono, (b) consumo de oxigênio, (c) perda de massa, (d) o aumento em número de células ou massa de células (se o polímero é somente de fonte de carbono) ou (e) exame físico da amostra por evidência de crescimento de colônia, destruição da amostra.

Uma comparação de alguns métodos de avaliação da biodegradabilidade de plásticos está a presentada na Tabela 3.20. 
3.20 - Métodos de biodegradabilidade de plásticos ${ }^{17}$

\begin{tabular}{|c|c|c|c|}
\hline Classificação & Características & $\begin{array}{c}\text { Fonte de } \\
\text { Microorganismos }\end{array}$ & $\begin{array}{c}\text { Métodos } \\
\text { normalizados } \\
\text { de teste }\end{array}$ \\
\hline Testes de campo & 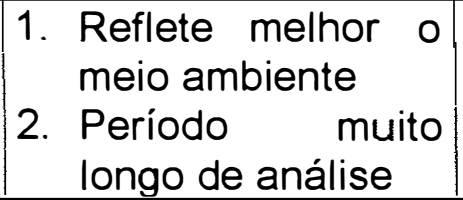 & $\begin{array}{l}\text { Aterro sanitário } \\
\text { Água do mar } \\
\text { Água fresca }\end{array}$ & $\begin{array}{l}\text { Nenhum } \\
\text { Nenhum } \\
\text { Nenhum }\end{array}$ \\
\hline $\begin{array}{l}\text { Microorganismos } \\
\text { (em laboratório) }\end{array}$ & $\begin{array}{l}\text { 1. } \begin{array}{l}\text { Reflete bem o } \\
\text { meio ambiente }\end{array} \\
\text { 2. Periodo longo de } \\
\text { análise }\end{array}$ & $\begin{array}{l}\text { Lama ativada } \\
\text { Terra adubada } \\
\text { Composto orgânico }\end{array}$ & $\begin{array}{l}\text { ASTM D } 5209 \\
\text { ASTM D } 5210 \\
\text { ASTM D } 5271 \\
\text { JIS K } 6950 \\
\text { Nenhum } \\
\text { ASTM D } 5338\end{array}$ \\
\hline $\begin{array}{l}\text { Microorganismos } \\
\text { específicos, } \\
\text { enzimas }\end{array}$ & $\mid \begin{array}{l}\text { 1. } \text { Reflete mau o } \\
\text { meio ambiente } \\
\text { 2. } \begin{array}{l}\text { Boa repetibilidade } \\
\text { 3. } \\
\text { Curto período de } \\
\text { análise }\end{array}\end{array}$ & & ASTM D 5247 \\
\hline
\end{tabular}

Para o estudo comparativo da degradação de bisnagas para creme dental de alumínio e de material laminado multicamadas, realizado no Instituto de Pesquisas Tecnológicas, foram coletadas amostras de alumínio e plástico de um aterro sanitário, onde verificou-se a perda de espessura de $1,1 \mu \mathrm{m} / a n o$ nas amostras de alumínio e nas amostras de plástico não foi encontrado grupos carbonila, através de ensaios de espectrofotometria no infravermelho, que evidenciaria a degradação do polímero. Para a amostra de alumínio submetida ao ensaio de imersão no chorume (condição crítica do aterro) a perda de espessura foi de $22,5 \mu \mathrm{m} / \mathrm{ano}$ e novamente a amostra de plástico não apresentou evidência de início de degradação da cadeia polimérica (Instituto de Pesquisas Tecnológicas, 1993a).

\footnotetext{
${ }^{17}$ MOTOISHI. Yassuo. Consultor da JICA - Japanese International Cooperation Agency. em visita ao Brasil. Comunicação pessoal em 25/04/96.
} 
Griffin (1976), descreveu a degradação de polietileno de baixa densidade em aterro sanitário. A evidência que ele encontrou foi a quebra por difusão de lipidios insaturados do composto para o polímero com a geração de peróxidos da oxidação.

Potts (1978) comenta que Nykvist observou que no solo em que havia polietileno marcado com Carbono-14 $\left({ }^{14} \mathrm{C}\right)$ após exposição à radiação ultravioleta e outras fontes de carbono metabolizável, houve a liberação de gás carbônico contaminado $\mathrm{com}^{14} \mathrm{C}$, indicando que parte da amostra de polietileno foi decomposta pelos microorganismos. Utilizando este método, Nykvist observou que o polietileno marcado $\mathrm{com}^{14} \mathrm{C}$ que não havia sido exposto ao ultravioleta também apresentou traços de ${ }^{14} \mathrm{C}$ no $\mathrm{CO}_{2}$ liberado, mas em muito menor intensidade. Assim, Nykvist concluiu que $\circ \mathrm{CO}_{2}$ deve ser formado a partir da fração de polietileno de menor peso molecular. Nykvist também demonstrou que um polimero que contenha um fotoacelerador, após a exposição à radiação ultravioleta, gera fragmentos oxidados, em parte volatilizados, que são convertidos em $\mathrm{CO}_{2}$ quando em contato com o solo.

Gomes et al. (1998) em suas pesquisas apresentou resultados da atividade de uma cultura bacteriana mista capaz de degradar a celulose em condições estritamente anaeróbicas. A cultura bacteriana foi obtida pelo enriquecimento de uma amostra de chorume originada da degradação de resíduos sólidos urbanos depositados em céu aberto. Os experimentos acompanharam a atividade microbiológica e celulolítica do chorume revelando aspectos do metabolismo. Neste trabalho, a celulose foi degradada a açúcares e ácidos orgânicos voláteis indicando o potencial dos microorganismos anaeróbicos celulolíticos na degradação da fração celulósica dos resíduos sólidos. 


\section{MATERIAIS E MÉTODOS}

\subsection{Materiais}

Foram usadas dois tipos de embalagens, sendo uma contendo leite e a outra de suco, pós-consumo. As estruturas escolhidas foram:

a. Leite: polietileno/cartão duplex impresso/polietileno/ alumínio/poliolefina (composta por duas camadas de polietileno) - Tetra Brik®

b. Suco: polietileno/cartão branco/polilefina (composta por: Surlyn (ionômero)/polietileno) - International Paper Toga $\AA$

Observação: as estruturas estão apresentadas na seguinte ordem: camada externa/intermediária/ camada interna.

As dimensões externas das caixas de leite e de suco eram, respectivamente, $95 \mathrm{~mm} \times 62 \mathrm{~mm} \times 165 \mathrm{~mm}$ e $235 \mathrm{~mm} \times 70 \mathrm{~mm} \times 70 \mathrm{~mm}$. A embalagem de leite não necessita de refrigeração para a conservação adequada do produto, enquanto que a outra necessita.

Materiais para o ensaio de degradação:

- Chorume - retirado da lagoa de aterro sanitário de Vila Albertina, que apresenta atividade microbiológica estável. Este aterro tem 22 anos de idade e foi desativado há 6 anos. $O$ aterro de Vila Albertina está localizado na rua Capitão José Aguirre de Camargo s/n (Fotos 1 e 2 ). 


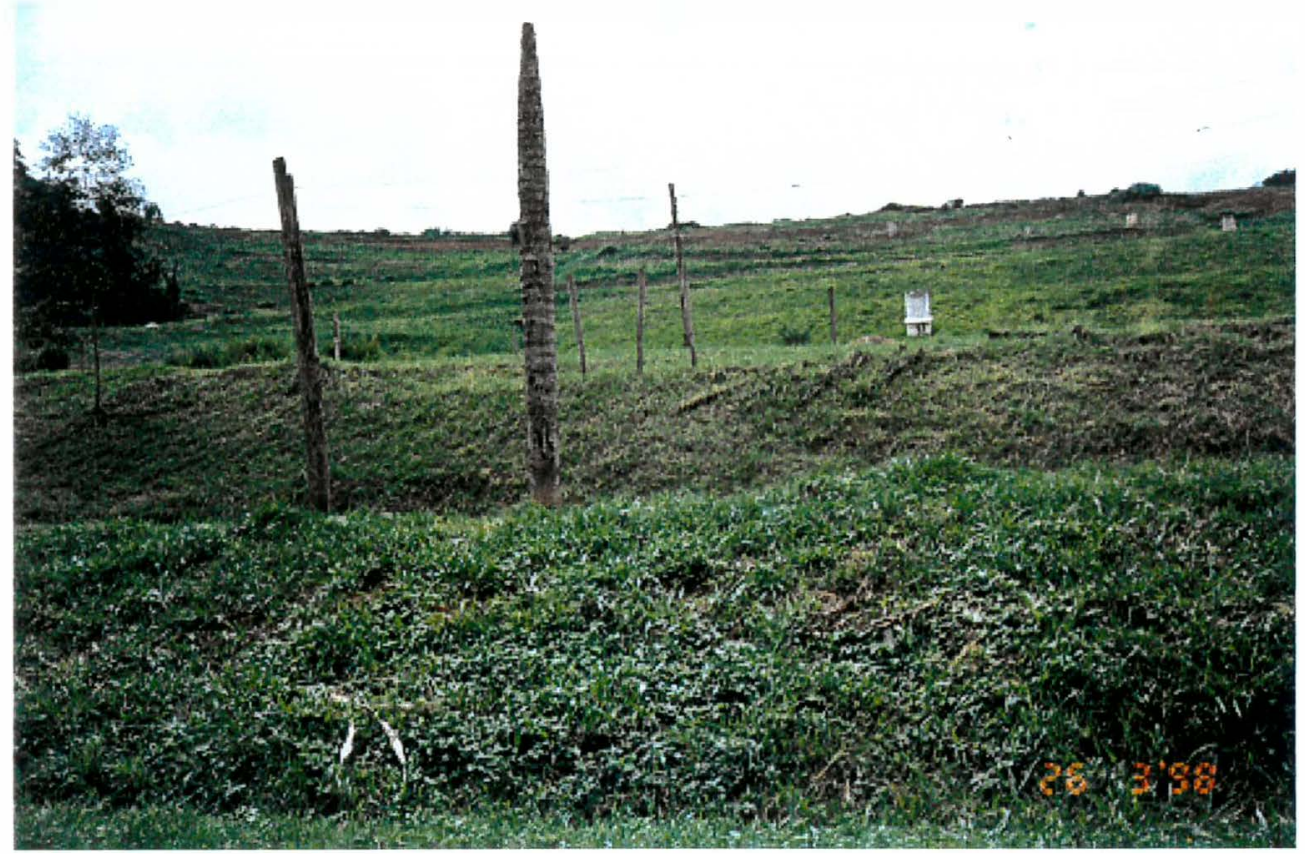

Foto 1 - Aterro sanitário de Vila Albertina

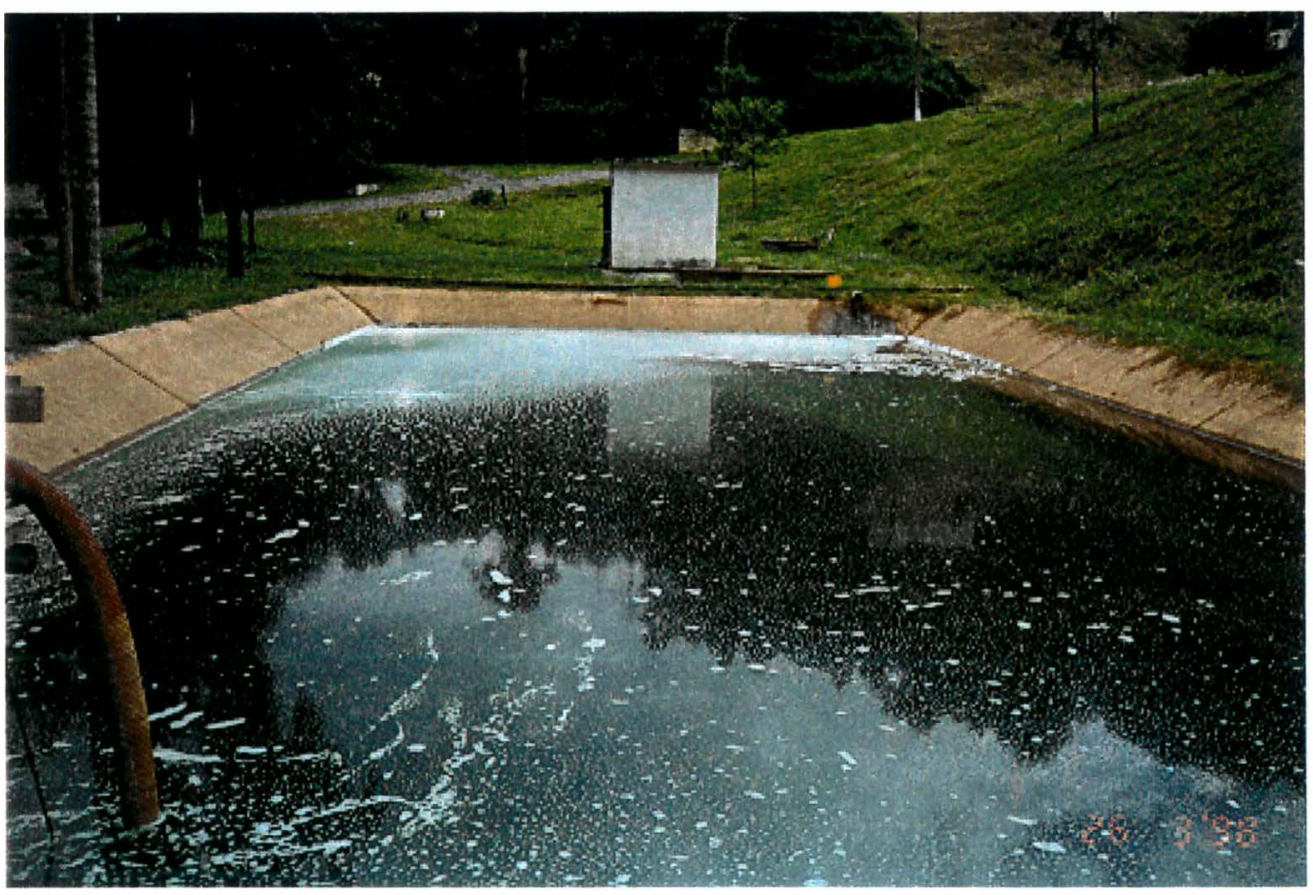

Foto 2 - Lagoa de chorume 


\subsection{Equipamentos:}

Para caracterização e análise periódica dos materiais e insumos foram utilizados os seguintes equipamentos:

- Micrômetro

- Dinamômetro Universal de Ensaios, marca Emic

- Medidor de rigidez Lhomargy

- Aparelho Mullen, marca Regmed

- Balança analítica

- Balança semi-analítica

- Espectrofotômetro no infra-vermelho

- Medidor de pH

- Papel indicador de pH

- Termômetro de bulbo

- Colorímetro, marca Macbeth Color - Eye série 1500

- Régua de aço

- Aparelho de Cobb

Para execução dos ensaios de degradabilidade:

- Câmara de envelhecimento com luz ultravioleta (U.V.)

O equipamento utilizado foi construído conforme a norma ASTM G53(91) - Standard Practice for Operating Ligth- and Water-Exposure Apparatus (Fluorescent UV - Condensation Type) for Exposure of Nonmetallic Materials (Foto 3) e pertence a Divisão de Química do Instituto de Pesquisas Tecnológicas (IPT). 
O equipamento é composto por um conjunto de lâmpadas fluorescentes UV-tipo B, na qual a radiação de $254 \mathrm{~nm}$ provocada por um arco elétrico em uma atmosfera de mercúrio de baixa pressão é transformada em uma luz com espectro distribuído em comprimentos de onda maiores, de $270 \mathrm{~nm}$ a $390 \mathrm{~nm}$, com pico em $313 \mathrm{~nm}$, através de sais de fósforo na parede de um tubo de vidro. Esta mesma máquina possui a opção de também expor as amostras a ciclos de condensação de umidade, conforme prevê este método ASTM.

- Recipiente para o chorume

Cuba de inóx mantida sobre três resistências elétricas controladas por sistema de termostato e contator que mantinham a temperatura do banho controlada $(50 \pm 2)^{\circ} \mathrm{C}$, em ambiente fechado (Foto 4). A temperatura do banho foi definida de acordo com dados de temperatura coletados internamente em aterro sanitário, os quais foram apresentados em relatório técnico emitido pelo IPT (1993b).

\section{- Estufa}

Esta estufa apresenta circulação de ar e foi mantida na temperatura de $(50 \pm 2)^{\circ} \mathrm{C}$. Este equipamento foi dotado de um termômetro digital para que pudéssemos monitorá-lo, e está localizado no Laboratório de Embalagens do IPT.

- Painel de exposição

Suporte de madeira para fixação das embalagens que serão expostas as intempéries. 


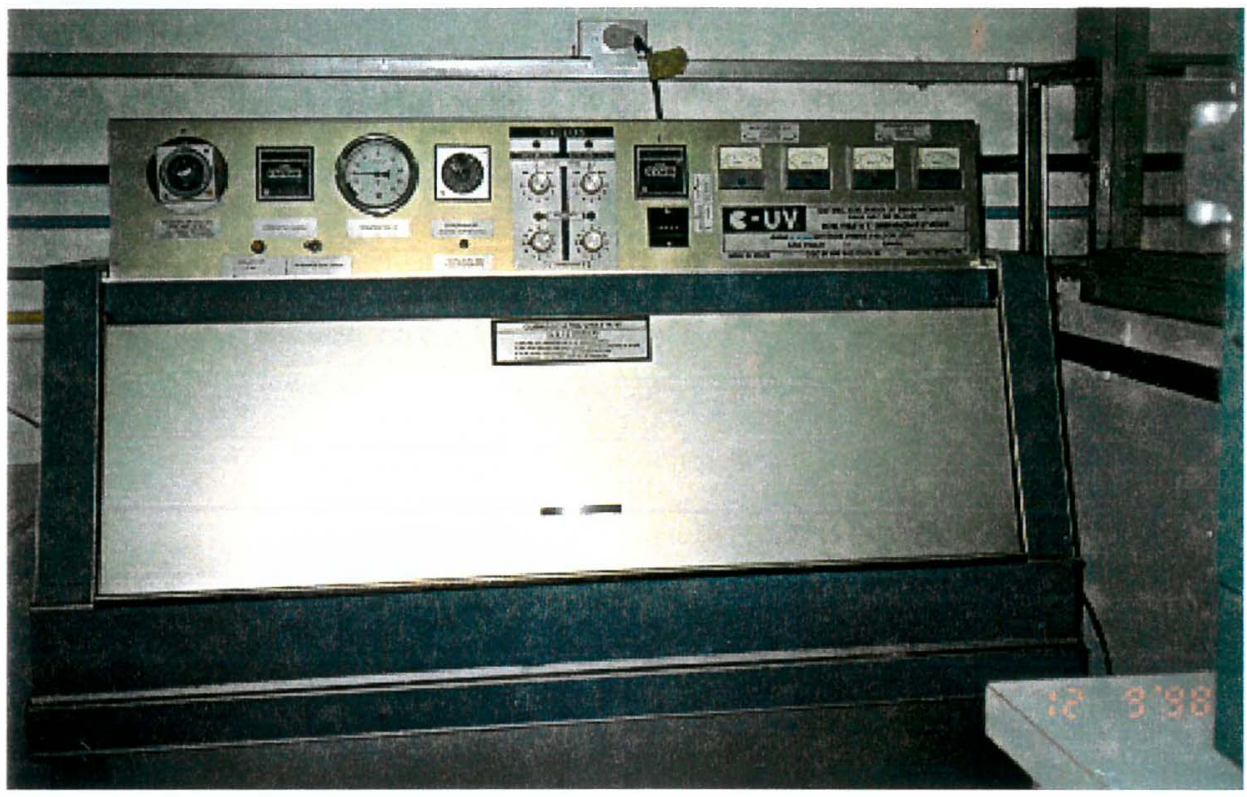

Foto 3 - Câmara de radiação ultravioleta e condensação

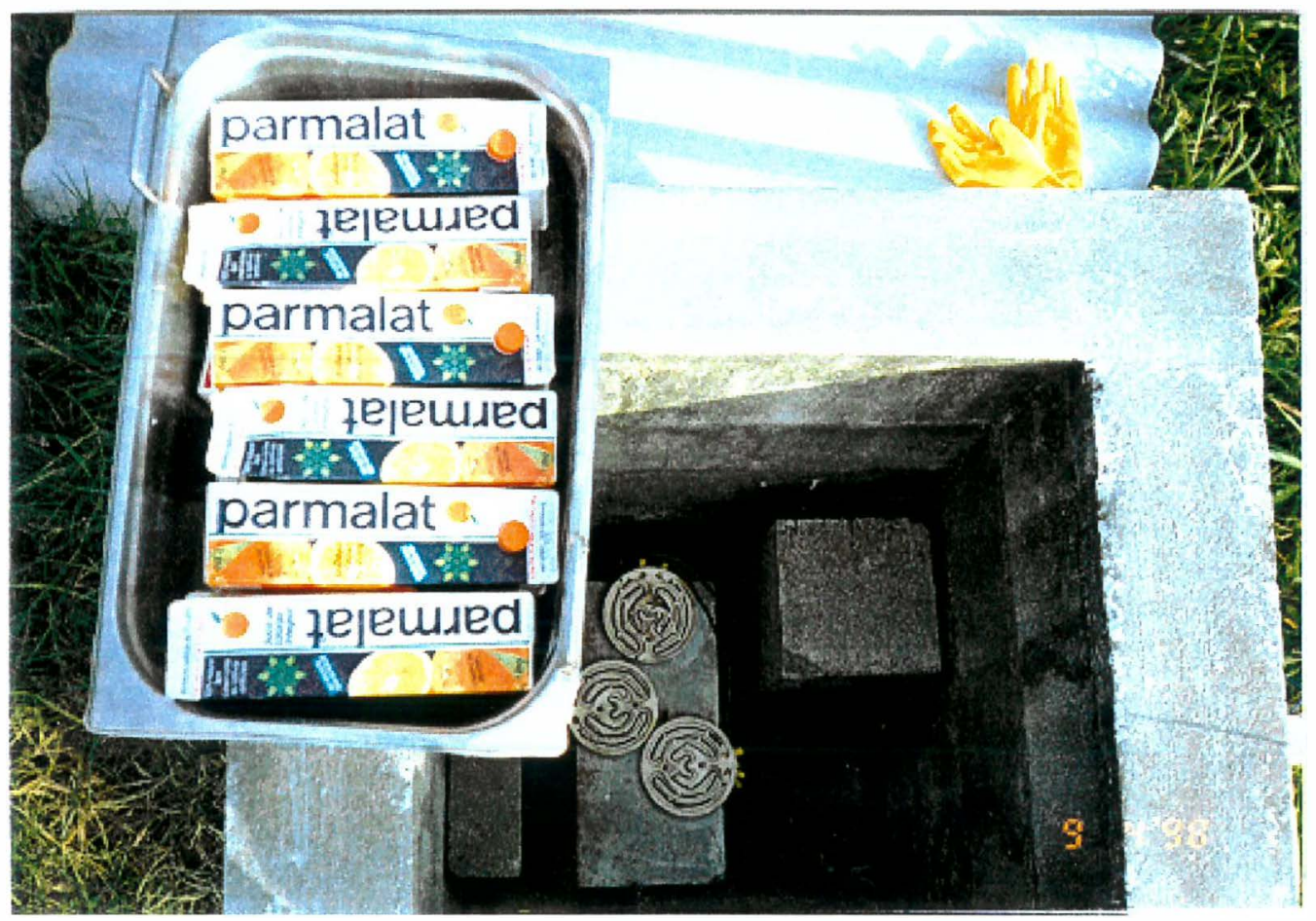

Foto 4 - Cuba e sistema de aquecimento 
- Estação de corrosão atmosférica

Estrutura metálica para suportar o painel de exposição com ângulo de inclinação igual a $30^{\circ} \mathrm{em}$ relação à horizontal e com a superfície exposta orientada na direção do norte geográfico. Esta estação está localizada no terraço do prédio 53 do IPT.

\subsection{Metodologia}

Os ensaios foram realizados no Instituto de Pesquisas Tecnológicas do Estado de São Paulo, nas áreas de "Celulose e Papel", "Embalagem", "Biotecnologia", "Corrosão", "Têxtil", "Plásticos e Borrachas" e "Química Instrumental".

\subsubsection{Caracterização e análises periódicas dos materiais:}

Para os ensaios de caracterização foram utilizadas 10 embalagens de cada tipo (leite e suco).

Para cada ensaio de degradação foram utilizadas seis embalagens, totalizando 24 embalagens de cada tipo. A cada período de degradação foi retirada uma embalagem.

a. Determinação da absorção lateral ("edge wicking") - este teste é destinado a determinação do grau de colagem interna do cartão pela absorção de líquidos pela seção transversal e foi realizado nas amostras originais com a finalidade de caracterização dos materiais. Foram utilizadas duas embalagens de cada tipo para retirar seis corpos-de-prova originais de 
cada amostra. Estes corpos-de-prova foram retirados nas duas direções (longitudinal e transversal) para amostra de embalagem de leite e somente na direção longitudinal para a amostra de embalagem de suco. A amostra de suco não permitia a retirada de corpo-de-prova na direção transversal porque apresentava vincos. O procedimento de ensaio seguiu as seguintes etapas:

- as amostras foram secas em estufa por 30 minutos à $1100 \mathrm{C}$;

- as amostras foram climatizadas por 10 minutos em ambiente com controle de temperatura e umidade $\left(20^{\circ} \mathrm{C} \pm 2^{\circ} \mathrm{C}\right.$ e $55 \% \pm 5 \%$ de umidade relativa);

- determinou-se a espessura de cada corpo-de-prova utilizando-se um micrômetro com precisão de 0,001mm;

- o método recomenda plastificar as duas faces da amostra com uma fita autoadesiva de poliéster, mas como as amostras já eram revestidas evitou-se esse manuseio dos corpos-de-prova;

-foram retirados corpos-de-prova nas duas direções com $2,5 \mathrm{~cm} \times 7,5 \mathrm{~cm}$, exceto para a amostra de suco somente na direção transversal

-determinou-se a massa dos corpos-de-prova em balança analítica.

-os corpos-de-prova foram submersos numa solução de ácido lático a 1\% em um recipiente do tipo bandeja, por 60 minutos. Para evitar a flutuação dos corpos-de-prova, foram colocadas réguas plásticas sobre eles;

- retirou-se os corpos-de-prova, colocou-se entre papéis absorventes e com um rolete pressionou-se para retirar 0 excesso de umidade. Em seguida, determinou-se a massa final na balança analítica;

- O cálculo da absorção, foi feito de duas maneiras, utilizando a fórmula 4.1, expressa em $\mathrm{kg} / \mathrm{m}^{2} . h$, e a fórmula 4.2 , que fornece a porcentagem de absorção.

$$
\begin{aligned}
& \left(\frac{\text { massa }_{f}-\text { massa }_{i}}{\text { espessura }}\right) \times 5 \\
& \left(\frac{\text { massa }_{f}-\text { massa }_{i}}{\text { massa }_{i}}\right) \times 100
\end{aligned}
$$




\section{b. Ensaio de determinação da rigidez (resistência à flexão}

dinâmica) - este ensaio foi realizado nas amostras originais e a cada período de envelhecimento (ultravioleta, natural e estufa) com a finalidade de caracterizar o material e verificar alterações nas amostras envelhecidas. Utilizou-se o método TAPPI T535 - Stiffness of Paperboard (Ressonance Length Method. Foi utilizada uma embalagem de cada tipo para retirar três corpos-de-prova em apenas uma direção, ou seja, na direção da altura da embalagem. Isto porque, nesta direção possibilitava a retirada de corpos-deprova de $25 \mathrm{~mm}$ de largura e comprimento $160 \mathrm{~mm}$ para a caixa de leite e de $180 \mathrm{~mm}$ de comprimento e mesma largura para a caixa de suco, sem a presença de vincos. Este método foi adotado, ao invés do mais utilizado pelas empresas (rigidez Taber), porque o corpo-de-prova não é afetado e pode ser aproveitado para outro ensaio. D'Almeida, 1997 em suas pesquisas verificou que a constante de relação da rigidez Lhomargy e a rigidez Taber é 1,9603, ou seja, para se obter o valor de rigidez Taber a partir do valor de rigidez Lhomargy deve-se dividí-lo por essa constante. Neste ensaio foram obtidos os valores de rigidez Lhomargy, espessura e calculados os módulos de elasticidade.

\section{c. Ensaio de determinação de absorção de água pela face} ("Cobb test")- este ensaio foi realizado somente nas amostras originais com a finalidade de caracterizar o material. Utilizou-se o método NBR 6731 - Papelão ondulado - Determinação da capacidade de absorção de água. Foram utilizadas três embalagens de cada tipo para retirar cinco corpos-de-prova para determinações do lado interno/externo e outros cinco para determinações do lado externo/interno. O tempo de absorção foi de 120 segundos. 
d. Ensaio de determinação da absorção de água da embalagem inteira - esta metodologia foi criada com a finalidade de possibilitar a comparação das embalagens do material original quanto à absorção de água, visto que, após a determinação pelo cobb test não foi possivel obter resultados distintos para cada amostra. Esta metodologia, também, pretende verificar o comportamento da absorção das embalagens na condição de temperatura utilizada no ensaio de degradabilidade por imersão no chorume. Determinou-se a massa de três embalagens inteiras de cada amostra, após 24 horas de condicionamento na temperatura de $20^{\circ} \mathrm{C}$ e $65 \%$ de umidade relativa, em balança semi-analítica. Estas embalagens foram colocadas na cuba de inóx cheia de água na temperatura de $50^{\circ} \mathrm{C}$ por 72 horas. Ao término deste período, as embalagens foram retiradas da cuba e após a retirada do excesso de água foi determinada a massa de cada uma, novamente, na mesma balança. Determinou-se a absorção da água de cada embalagem em porcentagem.

e. Ensaio de variação de massa - este ensaio foi realizado para avaliar a perda de massa das embalagens do ensaio de degradabilidade por imersão em chorume. Foi utilizada uma balança semi-analítica onde, determinou-se a massa inicial das embalagens, antes e após serem umidificados em água por 24 horas na temperatura ambiente. A cada período aproximado de um mês era retirada uma embalagem e realizada a pesagem, tomando-se a precaução de remover cuidadosamente o excesso de líquido (chorume) antes da pesagem. Esta mesma embalagem foi deixada secar ao ar por no mínimo cinco dias e submetida a pesagem para a determinação da massa seca. Calculou-se a variação de massa, subtraindo-se a massa inicial seca das massas secas de cada período e entre a massa úmida inicial e as massas úmidas de cada período. A variação de massa foi expressa em porcentagem. 
f. Ensaio de tração da estrutura - este ensaio foi realizado nas estruturas do material original úmido e seco e nas amostras retiradas a cada período dos envelhecimentos em estufa, natural e ultravioleta. Não foi possivel o ensaio de tração nas amostras retiradas do chorume porque ocorreu amassamentos acentuados nas amostras impedindo a retirada de corpos-deprova conforme o método recomenda. Adotou-se o método de ensaio ASTM D $882 / 1983$ - Standard test method for tensile properties of thin plastic sheeting que é apropriada para tração de filmes plásticos, porque adota velocidades de tracionamento conforme 0 alongamento da amostra. Entretanto, as estruturas são de materiais diferentes e era esperado um comportamento intríseco a amostra ensaiada. Foram realizadas três repetições para cada tipo em cada período e no original foram realizadas seis repetições, todos somente no sentido da altura das caixas. Os parâmetros deste ensaio foram: velocidade de tracionamento igual a $12,5 \mathrm{~mm} / \mathrm{min}$, distância inicial entre as garras igual a 100 $\mathrm{mm}$ e velocidade do gráfico de $200 \mathrm{~mm} / \mathrm{min}$. Neste ensaio foram obtidos dados de resistência à tração na ruptura, espessura, alongamento na ruptura e foram calculados os módulos de elasticidade.

g. Determinação da gramatura - este ensaio foi realizado nas embalagens originais e que foram submetidas a degradação por ultravioleta, estufa e natural. Para a amostra original, foram retirados seis corpos-de-prova e nas amostras de cada período de degradação foi feito um corpo-de-prova, isto porque tornaria este método não destrutivo e permitiria a continuação das análises. Sabe-se também, que uma maior área de corpo-de-prova para esta determinação torna-a mais precisa, por isso foi utilizada toda a face de exposição como corpo-de-prova. Adotou-se o método de ensaio MB-1321/80 Papelão ondulado - Determinação da gramatura. Esta determinação permitiu avaliar a perda de material de cada período nos diferentes métodos de degradabilidade. 
h. Ensaio de arrebentamento - este ensaio foi realizado nas estruturas do material original úmido e seco para a caracterização do material. Adotou-se o método de ensaio ABTCP P8 1994 - Papel - Determinação da resistência ao arrebentamento. Foi utilizada uma embalagem de cada tipo.

\section{i. Identificação, por espectrofotometria no infravermelho,} das camadas poliméricas - utilizando-se um espectrofotômetro determinou-se os polímeros utilizados nas estruturas do material original e ao final dos ensaios de degradabilidade fez-se novamente a identificação e comparou-se possiveis alterações ocorridas na cadeia polimérica. $O$ espectofotômetro utilizado é um AVATAR, modelo $x$, dotado de um detetor tipo DTGS $\mathrm{KBr}$, espalhador $\mathrm{KBr}$, fonte infravermelha com faixa de espectro de $4000 \mathrm{~cm}-1$ a 650 cm-1. Os parâmetros de leitura foram: resolução 4,000; ganho 8; velocidade do espelho 0,6329 cm/s; fenda 100,00; média de 200 leituras da amostra e média de 200 leituras do espectro de fundo (porta amostra vazio). A cada leitura foi realizada uma leitura do espectro de fundo que era compensada pelo programa de computador inerente do equipamento. Este programa utiliza a técnica de FTIR - transformada de Fourier para calcular os espectros.

Kelen (1983, p. 24), relata que a análise por espectrofotometria no infravermelho é utilizada para determinar quase todos os produtos de oxidação que se formam na cadeia polimérica. Este método é largamente utilizado para determinar grupos carbonilas, os quais podəm estar de várias formas no polímero oxidado, por exemplo, os aldeídos e cetonas $\left(\sim 1720 \mathrm{~cm}^{-1}\right)$, ácidos $\left(\sim 1710 \mathrm{~cm}^{-1}\right)$, ésters $\left(\sim 1745 \mathrm{~cm}^{-1}\right)$, e lactonas $\left(\sim 1780 \mathrm{~cm}^{-1}\right)$. Em situação similar é o caso dos grupos hidroxilas, por exemplo, uma banda na região de $3100-3700 \mathrm{~cm}^{-1}$ de um polipropileno oxidado é composta de absorções devido a grupos hidroxilas $(-\mathrm{OH})$ e hidrogênio ligado a grupos hidroperóxidos $(-\mathrm{OOH})$ 
(ambos absorvem em $\sim 3400 \mathrm{~cm}^{-1}$ ), como também hidroperóxidos livres ( 3550 $\left.\mathrm{cm}^{-1}\right)$.

\section{j. Análise instrumental da mudança de cor, por refletância,} da parte impressa - utilizando-se um colorímetro ligado a um computador, determinou-se a mudança de cor dos corpos-de-prova que foram submetidos a degradação por ultravioleta com relação a um corpo-de-prova original, tomado como padrão. Foi demarcada uma região da impressão para as leituras de cada amostra (suco - cor laranja e leite - cor vermelha). Esta marca foi utilizada para posicionar todas as amostras no porta-amostra do equipamento, dessa forma a região de leitura foi sempre a mesma para todas as amostras.

Adotou-se o método de ensaio da norma AATCC - Evaluation Procedure 7 - Instrumental Assessment of Change in Color of a Test Specimen desenvolvido pelo comitê RA 36 da AATCC - American Association of Textile Chemists and Colorists. O equipamento possui a geometria difusa/8. O cálculo do componente especular ultravioleta exclusa CIEL ${ }^{*} a^{*} b^{\star}$ foi feito com base no iluminante $D_{65}$ e observador $10^{\circ}$.

A mudança de cor foi quantificada pela diferença $(\Delta)$ dos parâmetros psicométricos (luminosidade, $L^{\star}$, saturação, $C^{\star}$, e tonalidade, $h$ ) entre a amostra tratada e seu padrão. Este cálculo foi realizado automaticamente pelo equipamento segundo as expressões (4.3) reproduzidas da norma de ensaio citada conforme a Convenção da CIE (Comission Internacionale de l'Eclairage) de 1976.

Uma representação gráfica dos termos psicométricos do Sistema CIEL ${ }^{*} a^{*} b^{\star}$, pode ser vista na Figura 4.1 (Maluf, 1995). 
$L^{*}=$ luminosidade psicométrica

$a^{*}=$ eixo vermelho $(+) /$ verde $(-)$

$\mathrm{b}^{\star}=$ eixo amarelo $(+) /$ azul $(-)$

$C^{*}{ }_{a b}=$ saturação $($ croma $)=\left(a^{\star^{2}}+b^{\star^{2}}\right)^{1 / 2}$

$h_{a b}=$ ângulo de tonalidade (hue) $=\operatorname{arc~tg~}\left(b^{\star} / a^{*}\right)$.

$\Delta \mathrm{H}^{\star}{ }_{\mathrm{ab}}=$ diferença de tonalidade $=\left[\left(\Delta \mathrm{E}^{\star}\right)^{2}-\left(\Delta \mathrm{L}^{*}\right)^{2}-\left(\Delta \mathrm{C}^{\star}\right)^{2}\right]^{1 / 2}$

$\Delta \mathrm{E}^{\star}{ }_{\mathrm{ab}}=$ diferença de cor $=\left[\left(\Delta \mathrm{L}^{\star}\right)^{2}+\left(\Delta \mathrm{b}^{\star}\right)\right]^{1 / 2}$
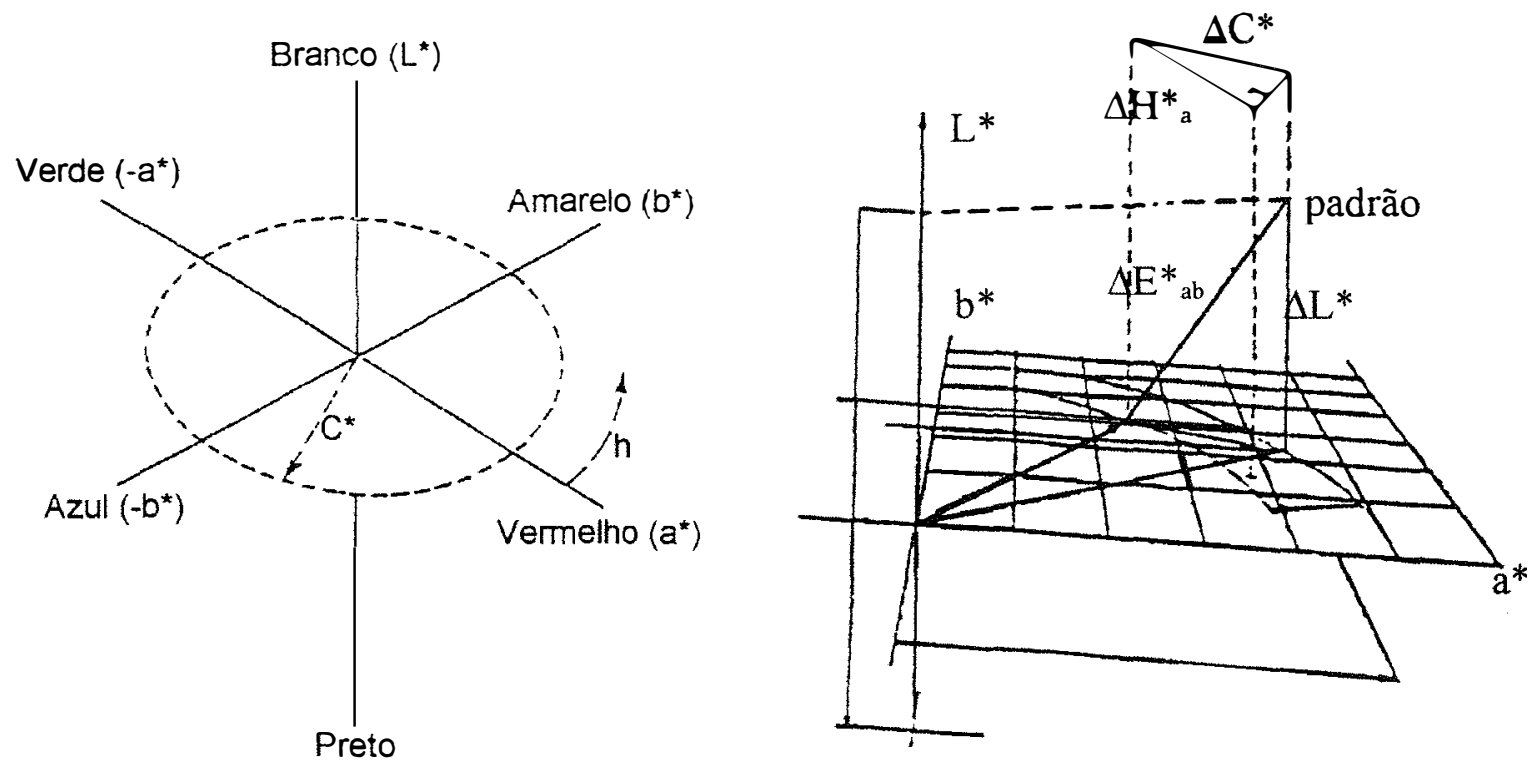

Figura 4.1 - Representação gráfica dos termos psicométricos do Sistema CIEL*a*b*, 1976

I. Análises químicas do chorume realizadas por via úmida, segundo a "Standard Methods for the Examination of Water and Wasterwater" 14a Ed. 1975 para a determinação da alcalinidade total. sulfeto total, sólidos suspensos totais, sólidos suspensos voláteis, sólidos suspensos fixos, sólidos totais, sólidos voláteis totais e sólidos fixos totais. Foram feitas estas determinações no chorume antes e ao término dos ensaios. 
m. Determinação da demanda bioquímica de oxigênio (DBO) - esta determinação mede a quantidade de oxigênio consumida pelos microorganismos na oxidação da matéria orgânica presente na água ou na água residuária. Quanto maior o grau de poluição, maior a DBO. Adotou-se o método de ensaio ABTCP ES 1994 - Efluentes - Determinação da demanda bioquímica de oxigênio (DBO) para analisar amostras do chorume antes e ao término dos ensaios.

n. Determinação da demanda química de oxigênio (DQO) esta determinação mede a quantidade de oxigênio consumida na oxidação química da matéria orgânica presente na água ou na água residuária. Em geral, a DQO é maior que a DBO e nem sempre é possível correlacioná-las. Adotou-se o método de ensaio ABTCP E9 1994 - Efluentes - Determinação da demanda química de oxigênio (DQO) para analisar amostras do chorume antes e ao término dos ensaios.

o. Determinação do pH - utilizou-se um pH-metro da marca Metler para a realização das medidas de $\mathrm{pH}$ antes e ao término dos ensaios. Adotou-se o método de ensaio ABTCP E10 1994 - Efluentəs - Determinação de $\mathrm{pH}$. Foram realizadas, também, determinações durante 0 ensaio utilizando 0 papel indicador de $\mathrm{pH}$, marca Merck.

\subsubsection{Ensaios de degradabilidade}

Foram utilizadas as próprias embalagens para exposição nos ensaios de degradabilidade, exceto para a ultravioleta que o corpo-de-prova é de acordo com a norma ASTM G-53, citada anteriormente. 
Como dito, foi adotado uma embalagem por período de exposição. Os períodos para imersão em chorume, exposição em temperatura e exposição às intempéries foram aproximadamente, em meses: 1, 2 , 3, 4, 5 e 6. Para o ensaio de ultravioleta os períodos, em horas, foram: 12, 24, 48, 72 , 110 e 200 .

a. Ensaio de degradabilidade por ultravioleta - $O$ objetivo deste ensaio é avaliar a degradabilidade dos materiais após exposição em luz ultravioleta com $310 \mathrm{~nm}$, reconhecidamente a luz que degrada polímeros, através da quebra das ligações da cadeia polimérica. Adotou-se o método ASTM G-53 para execução do ensaio e os seguintes ciclos alternados de exposição: quatro horas de luz ultravioleta na temperatura de $30^{\circ} \mathrm{C}$ e quatro horas de condensação na temperatura de $60^{\circ} \mathrm{C}$. Doze corpos-de-prova de dimensões padronizadas, sendo seis de um tipo de embalagem e seis da outra, foram submetidos a estes ciclos durante os períodos determinados anteriormente. Após cada período foi retirado um corpo-de-prova de cada tipo de embalagem e submeteu-se as determinações: tração da estrutura, gramatura, espectrofotometria no infravermelho e colorimetria.

\section{b. Ensaio de degradabilidade por imersão em chorume - $A$}

simulação de condição de um aterro a que ficam sujeitos os materiais enterrados, foi muitas vezes estudada e tentativas de normalizar esta simulação foram propostas. Mesmo estes estudos reconhecem a impossibilidade de reproduzir as condições reais de um, aterro, devido à dificuldade de controle da atividade microbiológica e das condições climáticas. O chorume é um dos principais produtos da degradação dos resíduos sólidos e possui elevado potencial hidrolítico devido à presença de bactérias e metabólicos (Gomes et al, 1998). A simulação por imersão em chorume não representa a realidade do aterro mas sim uma condição crítica do mesmo válida para fins comparativos. 
O objetivo deste ensaio é submeter as amostras a condição crítica encontrada nos aterros sanitários e avaliar as amostras de forma comparativa. Entretanto, a própria qualidade do chorume varia com a idade desse aterro (aterros mais novos apresentam maior atividade microbiológica) e com as condições climáticas (há uma diluição na ocorrência de chuvas). O chorume utilizado neste estudo, portanto, não é representativo de qualquer chorume, porém foi adotado com o critério de idade do aterro.

O chorume coletado no aterro de Vila Albertina foi colocado em um recipiente fechado de aço inoxidável sobre resistências elétricas que mantinham a solução, juntamente com as embalagens, na temperatura de $(50 \pm 2)^{\circ} \mathrm{C}$ em ambiente fechado. A falta de agitação constante da cuba foi uma opção na tentativa de simular a falta de mistura existente nos processos de digestão anaeróbica de resíduos sólidos, como os característicos do lixo urbano. As embalagens foram imersas (no início, parcialmente, devido a flưuuação das embalagens), de forma horizontal aleatória, e a cada período foram retiradas para as análises visuais, perda de massa e determinação da resistência à tração. As embalagens do último período foram submetidas a determinação do polímero por espectrofotometria no infravermelho.

c. Ensaio de envelhecimento em estufa a $(50 \pm 2)^{\circ} \mathrm{C}-\mathrm{O}$ objetivo deste ensaio é avaliar a variável temperatura do ensaio de degradabilidade por imersão em chorume nas amostras. As embalagens foram submetidas a esta temperatura em uma estufa controlada com circulação de ar e foram retiradas a cada período para as análises de rigidez Lhomargy, tração da estrutura e gramatura. As embalagens do último período foram submetidas a determinação do polímero por espectrofotometria no infravermelho. 


\section{d. Ensaio de degradabilidade por intempéries - $O$ objetivo} deste ensaio é avaliar a degradabilidade dos materiais após exposição natural das intempéries. Este ensaio foi realizado com base na norma NBR 6209/1986 - Materiais Metálicos Não Revestidos - Ensaio não-acelerado de corrosão atmosférica. As embalagens foram fixadas com adesivo, tipo hot-melt, no painel de exposição. Este painel foi colocado na estação de corrosão para que as embalagens fossem submetidas a luz natural e intempéries durante os períodos determinados. Após cada período, foram retiradas embalagens para a execução das análises de rigidez Lhomargy, tração da estrutura e gramatura. As amostras do último período foram submetidas a análise por espectrofotometria no infravermelho para verificar possíveis alterações da cadeia polimérica.

A estação de corrosão atmosférica, segundo dados metereológicos fornecidos pelo IAG/USP (que obtiveram esses dados do Parque estadual das Fontes do Ipiranga - Bairro da Água Funda - São Paulo/SP), do período (setembro/97 a março/98), apresentou os parâmetros ambientais da Tabela 4.1.

Tabela 4.1 - Parâmetros Ambientais

\begin{tabular}{l|c|c|c|c|c|c|c}
\hline \multicolumn{1}{c|}{ Parâmetro } & $\begin{array}{c}1_{-}^{\circ} \text { mês } \\
09 / 97\end{array}$ & $\begin{array}{c}2_{-}^{\circ} \text { mês } \\
10 / 97\end{array}$ & $\begin{array}{c}3_{-}^{\circ} \text { mês } \\
11 / 97\end{array}$ & $\begin{array}{c}4_{-}^{\circ} \text { mês } \\
12 / 97\end{array}$ & $\begin{array}{c}5_{-}^{\circ} \text { mês } \\
01 / 98\end{array}$ & $\begin{array}{c}6_{-}^{\circ} \text { mês } \\
02 / 98\end{array}$ & $\begin{array}{c}7_{-}^{\circ} \text { mês } \\
03 / 98\end{array}$ \\
\hline Temperatura $\left({ }^{\circ} \mathrm{C}\right)$ & 18,4 & 19,6 & 21,5 & 23,1 & 23,9 & 23,6 & 22,5 \\
\hline U.R. (\%) & 80 & 84 & 85 & 80 & 80 & 83 & 84 \\
\hline Precipitação (mm) & 130,6 & 126,4 & 164,0 & 206,5 & 217,0 & 239,0 & 241,0 \\
\hline Insolação (horas) & 139,2 & 152,8 & 122,7 & 138,8 & 207,8 & 139,0 & 151,0 \\
\hline Direção dos ventos predominantes & SSE & SSE & SSE & SSE & ENE & WNW & SSE \\
\hline $\begin{array}{l}\text { Velocidade do ventos } \\
\text { predominantes (km/h) }\end{array}$ & 5,6 & 7,0 & 5,9 & 6,1 & 6,0 & 5,5 & 5,5 \\
\hline
\end{tabular}




\section{RESULTADOS}

\subsection{Caracterização das Embalagens Multicamadas}

As características do material multicamada, sem envelhecimento, das embalagens de leite e suco foram determinadas conforme métodos citados no capítulo anterior.

As propriedades determinadas foram: gramatura, rigidez Lhomargy, módulo de elasticidade na direção " $Z$ ", tensão de ruptura, módulo de elasticidade na direção longitudinal a altura da caixa, alongamento na ruptura, resistência ao arrebentamento, absorção lateral de água, absorção de água da face e absorção de água da embalagem inteira.

As camadas plásticas de cada embalagem foram analisadas quanto a sua estrutura química através de espectrofotometria no infravermelho.

\subsubsection{Gramatura}

Esta determinação seguiu o método descrito no item $g$ de 4.3.1 do capítulo 4. Os resultados encontrados para as embalagens de suco e leite estão apresentados na Tabela 5.1. 
Tabela 5.1 - Resultados de gramatura dos materiais multicamada $\left(\mathrm{g} / \mathrm{m}^{2}\right)$

\begin{tabular}{c|c|c}
\hline Corpo-de-prova & Suco & Leite \\
\hline 01 & 423 & 356 \\
\hline 02 & 424 & 356 \\
\hline 03 & 425 & 354 \\
\hline 04 & 417 & 358 \\
\hline 05 & 422 & 354 \\
\hline 06 & 421 & 359 \\
\hline Média & 422 & 356 \\
\hline Desvio-padrão & 3 & 2 \\
\hline
\end{tabular}

\subsubsection{Rigidez Lhomargy e módulo de elasticidade na direção "Z"}

Esta determinação seguiu o método descrito no item $b$ de 4.3.1 do capítulo 4. Para as determinações da rigidez Lhomargy e do módulo de elasticidade na direção " $Z$ " foi necessário, também, determinar a espessura e a gramatura de cada corpo-de-prova. Os resultados encontrados para as embalagens de suco e leite estão apresentados nas Tabelas 5.2 e 5.3.

Tabela 5.2 - Resultados do ensaio de rigidez Lhomargy - Amostra Original Suco

\begin{tabular}{l|c|c|c|c}
\hline $\mathrm{cp}$ & $\begin{array}{l}\text { Espessura } \\
(\mathrm{mm})\end{array}$ & $\begin{array}{l}\text { Gramatura } \\
\left(\mathrm{g} / \mathrm{m}^{2}\right)\end{array}$ & $\begin{array}{l}\text { Rigidez } \\
\text { Lhomargy } \\
(\mathrm{N} . \mathrm{mm})\end{array}$ & $\begin{array}{l}\text { Módulo de } \\
\text { Elasticidade } \\
\left(\mathrm{N} / \mathrm{mm}^{2}\right)\end{array}$ \\
\hline 01 & 0,570 & 427 & 28,5 & 1847 \\
\hline 02 & 0,570 & 432 & 30,4 & 1970 \\
\hline 03 & 0,575 & 432 & 30,4 & 1919 \\
\hline 04 & 0,565 & 435 & 29,0 & 1930 \\
\hline 05 & 0,570 & 427 & 28,5 & 1847 \\
\hline 06 & 0,570 & 430 & 27,2 & 1763 \\
\hline média & $\mathbf{0 , 5 7 0}$ & $\mathbf{4 3 1}$ & 29,0 & 1879 \\
\hline $\begin{array}{l}\text { Desvio- } \\
\text { padrão }\end{array}$ & $\mathbf{0 , 0 0 3}$ & 3 & 1,2 & 75 \\
\cline { 1 - 2 } & & 3 & &
\end{tabular}


Tabela 5.3 - Resultados do ensaio de rigidez Lhomargy - Amostra Original Leite

\begin{tabular}{l|c|c|c|c}
\hline $\mathrm{cp}$ & $\begin{array}{l}\text { Espessura } \\
(\mathrm{mm})\end{array}$ & $\begin{array}{l}\text { Gramatura } \\
\left(\mathrm{g} / \mathrm{m}^{2}\right)\end{array}$ & $\begin{array}{l}\text { Rigidez } \\
\text { Lhomargy } \\
(\mathrm{N} . \mathrm{mm})\end{array}$ & $\begin{array}{l}\text { Módulo de } \\
\text { Elasticidade } \\
\left(\mathrm{N} / \mathrm{mm}^{2}\right)\end{array}$ \\
\hline 01 & 0,530 & 360 & 58,6 & 4724 \\
\hline 02 & 0,525 & 365 & 52,3 & 4334 \\
\hline 03 & 0,525 & 365 & 67,3 & 5577 \\
\hline 04 & 0,520 & 358 & 58,2 & 4970 \\
\hline 05 & 0,530 & 366 & 62,1 & 5005 \\
\hline 06 & 0,530 & 359 & 53,8 & 4335 \\
\hline 07 & 0,530 & 360 & 53,9 & 4344 \\
\hline média & $\mathbf{0 , 5 2 7}$ & $\mathbf{3 6 2}$ & $\mathbf{5 8 , 0}$ & $\mathbf{4 7 5 6}$ \\
\hline $\begin{array}{l}\text { Desvio- } \\
\text { padrão }\end{array}$ & $\mathbf{0 , 0 0 4}$ & $\mathbf{3}$ & $\mathbf{5 , 3}$ & $\mathbf{4 6 7}$ \\
\hline
\end{tabular}

\subsubsection{Tensão de ruptura, módulo de elasticidade e alongamento na ruptura}

O método de ensaio de tração escolhido para a determinação das propriedades de tensão de ruptura, módulo de elasticidade e alongamento na ruptura baseia-se num método de tração de filmes plásticos, conforme descreve o item $f$ de 4.3.1 do capítulo 4 .

Para verificar a adequação deste método e uma caracterização inicial das amostras, incluindo uma análise do comportamento de resistência das amostras quando umedecidas (imersão por duas horas em água na temperatura ambiente) foram realizados ensaios preliminares conforme apresentado na Tabela 5.4. Estes resultados não serão utilizados para analisar a degradação da embalagem. 
Tabela 5.4 - Resultados preliminares do ensaio de tração da estrutura

\begin{tabular}{|c|c|c|c|c|c|c|}
\hline $\begin{array}{l}\text { Emb. } \\
\text { Suco }\end{array}$ & & \begin{tabular}{|l|}
$\begin{array}{l}\text { espessura } \\
(\mathrm{mm})\end{array}$ \\
\end{tabular} & \begin{tabular}{|l|} 
Módulo de \\
elasticidade \\
(kgf/ $\left./ \mathrm{mm}^{2}\right)$
\end{tabular} & \begin{tabular}{|l|}
$\begin{array}{l}\text { Alongamento na } \\
\text { ruptura (\%) }\end{array}$ \\
\end{tabular} & $\begin{array}{l}\text { Carga máxima na } \\
\text { ruptura (kgf) }\end{array}$ & $\begin{array}{l}\text { Carga do } \\
\text { primeiro } \\
\text { pico (kgf) }\end{array}$ \\
\hline & 1 & 0,59 & 68 & 9,5 & 23 & 12 \\
\hline úmido & 2 & 0,58 & 67 & 9,9 & 24 & 12 \\
\hline & 3 & 0,59 & 70 & 10,5 & 24 & 12 \\
\hline & 4 & 0,58 & 103 & 8,5 & 27 & 12 \\
\hline seco & 5 & 0,58 & 83 & 7,8 & 26 & 11 \\
\hline & 6 & 0,57 & 86 & 8,3 & 26 & 11 \\
\hline \multirow{2}{*}{\multicolumn{7}{|c|}{$\begin{array}{l}\text { Emb. } \\
\text { Leite }\end{array}$}} \\
\hline & & & & & & \\
\hline \multirow{3}{*}{ úmido } & 1 & 0,55 & 122 & 3,5 & 29 & 12 \\
\hline & 2 & 0,54 & 118 & 3,7 & 31 & 12 \\
\hline & 3 & 0,52 & 134 & 3,2 & 31 & 12 \\
\hline \multirow{3}{*}{ seco } & 4 & 0,52 & 174 & 2,8 & 40 & 12 \\
\hline & 5 & 0,53 & 241 & 2,7 & 39 & 11 \\
\hline & 6 & 0,53 & $\star$ & 2,9 & 39 & 12 \\
\hline \multicolumn{7}{|l|}{ Médias } \\
\hline \multirow[t]{2}{*}{ Suco } & $\begin{array}{l}\text { embalagens } \\
\text { úmidas }\end{array}$ & 0,59 & 68 & 9,9 & 24 & 12 \\
\hline & $\begin{array}{l}\text { embalagens } \\
\text { secas }\end{array}$ & 0,58 & 91 & 8,2 & 26 & 11 \\
\hline \multirow[t]{2}{*}{ Leite } & $\begin{array}{l}\text { embalagens } \\
\text { úmidas }\end{array}$ & 0,54 & 122 & 3,4 & 30 & 12 \\
\hline & $\begin{array}{l}\text { embalagens } \\
\text { secas }\end{array}$ & 0,53 & 207 & 2,7 & 39 & 11 \\
\hline
\end{tabular}

Os resultados de carga de ruptura encontrados na Tabela 5.4 foram utilizados para calcular a retenção da resistência a úmido de cada embalagem após duas horas de imersão em água. As embalagens de suco e de leite apresentaram respectivamente os seguintes valores de retenção da resistência a úmido: 0,91 e 0,76.

Foram retirados novos corpos de prova das amostras de suco e leite e determinou-se as características originais de tensão de ruptura, módulo de elasticidade e alongamento na ruptura de acordo com o método descrito anteriormente. Os resultados das Tabelas 5.5 e 5.6 dessas características serão utilizados para comparar com os resultados das amostras envelhecidas. 
Tabela 5.5 - Resultados do ensaio de tração - Amostra Original - Suco

\begin{tabular}{l|c|c|c}
\hline $\mathrm{CP}$ & $\begin{array}{c}\text { Alongamento } \\
\text { na ruptura } \\
(\%)\end{array}$ & $\begin{array}{c}\text { Tensão de } \\
\text { ruptura } \\
(\mathrm{Mpa})\end{array}$ & $\begin{array}{c}\text { Módulo de } \\
\text { Elasticidade } \\
\text { (MPa) }\end{array}$ \\
\hline 01 & 8,5 & 19,4 & 616 \\
\hline 02 & 7,8 & 19,6 & 771 \\
\hline 03 & 8,3 & 19,8 & 631 \\
\hline 04 & 8,6 & 20,9 & 635 \\
\hline 05 & 8,4 & 19,7 & 654 \\
\hline 06 & 8,4 & 20,4 & 633 \\
\hline média & 8,3 & 20,0 & 657 \\
\hline Desvio- & 0,3 & 0,6 & 57 \\
padrão & & & \\
\hline
\end{tabular}

Tabela 5.6 - Resultados do ensaio de tração - Amostra Original - Leite

\begin{tabular}{l|c|c|c}
\hline $\mathrm{cp}$ & $\begin{array}{c}\text { Alongamento } \\
\text { na ruptura } \\
(\%)\end{array}$ & $\begin{array}{c}\text { Tensão de } \\
\text { ruptura } \\
(\mathrm{Mpa})\end{array}$ & $\begin{array}{c}\text { Módulo de } \\
\text { Elasticidade } \\
(\mathrm{MPa})\end{array}$ \\
\hline 01 & 5,4 & 28,0 & 762 \\
\hline 02 & 5,1 & 28,3 & 785 \\
\hline 03 & 4,4 & 28,2 & 797 \\
\hline 04 & 5,4 & 28,3 & 728 \\
\hline 05 & 5,5 & 28,3 & 777 \\
\hline 06 & 4,7 & 28,4 & 888 \\
\hline 07 & 4,6 & 28,4 & 851 \\
\hline média & 5,0 & 28,2 & 798 \\
\hline Desvio- & 0,4 & 0,1 & 55 \\
padrão & & & \\
\hline
\end{tabular}

\subsubsection{Resistência ao arrebentamento}

Este ensaio seguiu a metodologia conforme descrita no item $h$ de 4.3.1 do capítulo 4. Os resultados obtidos do material sem envelhecimento, após imersão em água por duas horas e o seco estão apresentados na Tabela 5.7 . 
Tabela 5.7 - Resultados do ensaio de arrebentamento

\begin{tabular}{|c|c|c|c|}
\hline & & lado externo $\left(\mathrm{kgf} / \mathrm{cm}^{2}\right)$ & lado interno $\left(\mathrm{kgf} / \mathrm{cm}^{\circ}\right)$ \\
\hline \multirow[t]{2}{*}{ Embalagem de Leite } & úmida & $\begin{array}{l}9,6 \\
9,5\end{array}$ & $\begin{array}{l}9,1 \\
8,7\end{array}$ \\
\hline & seca & $\begin{array}{l}8,6 \\
9,6\end{array}$ & $\begin{array}{l}7,7 \\
8,9\end{array}$ \\
\hline \multirow[t]{2}{*}{ Embalagem de Suco } & úmida & $\begin{array}{l}10,3 \\
12,1\end{array}$ & $\begin{array}{l}10,0 \\
10,2\end{array}$ \\
\hline & seca & $\begin{array}{l}10,7 \\
11,8\end{array}$ & $\begin{array}{l}9,8 \\
9,7\end{array}$ \\
\hline
\end{tabular}

\subsubsection{Absorção lateral de água}

Este ensaio seguiu a metodologia conforme descrita no item a de 4.3.1 do capítulo 4. Os resultados desta análise para as embalagens de leite e suco estão apresentados nas Tabelas 5.8 e 5.9.

Tabela 5.8 - Resultados do ensaio de absorção lateral da amostra de leite

\begin{tabular}{|c|c|c|c|c|}
\hline $\begin{array}{l}\text { Sentido de } \\
\text { corte }\end{array}$ & $\mathrm{cp}$ & $\begin{array}{c}\text { Espessura* } \\
(\mathrm{mm})\end{array}$ & $\begin{array}{c}\text { Absorção Lateral } \\
\left(\mathrm{kg} / \mathrm{m}^{2} / \mathrm{h}\right)\end{array}$ & Absorção Lateral (\%) \\
\hline \multirow{9}{*}{$\begin{array}{l}\text { Altura da } \\
\text { caixa }\end{array}$} & 01 & 0,508 & 0,428 & 6,8 \\
\hline & 02 & 0,510 & 0,451 & 7,0 \\
\hline & 03 & 0,493 & 0,527 & 8,3 \\
\hline & 04 & 0,493 & 0,446 & 7,0 \\
\hline & 05 & 0,510 & 0,363 & 5,7 \\
\hline & 06 & 0,510 & 0,358 & 5,6 \\
\hline & 07 & 0,490 & 0,423 & 6,6 \\
\hline & média & 0,502 & 0,428 & 6,7 \\
\hline & $\begin{array}{l}\text { Desvio- } \\
\text { padrão }\end{array}$ & 0,009 & 0,058 & 0,9 \\
\hline \multirow{8}{*}{$\begin{array}{l}\text { Largura } \\
\text { da } \\
\text { caixa }\end{array}$} & 01 & 0,500 & 0,410 & 6,3 \\
\hline & 02 & 0,500 & 0,450 & 6,3 \\
\hline & 03 & 0,510 & 0,368 & 5,9 \\
\hline & 104 & 0,508 & 0,413 & 6,6 \\
\hline & 05 & 0,503 & 0,412 & 6,5 \\
\hline & 06 & 0,527 & 0,337 & 5,7 \\
\hline & Média & 0,508 & 0,398 & 6,2 \\
\hline & $\begin{array}{l}\text { Desvio- } \\
\text { padrão }\end{array}$ & 0,010 & 0,040 & 0,3 \\
\hline
\end{tabular}

*as espessuras apresentadas para cada corpo-de-prova é uma média de três leituras. 
Tabela 5.9 - Resultados do ensaio de absorção lateral da amostra de suco

\begin{tabular}{|c|c|c|c|c|}
\hline $\begin{array}{l}\text { Sentido de } \\
\text { corte }\end{array}$ & $\mathrm{cp}$ & $\begin{array}{l}\text { Espessura }^{*} \\
(\mathrm{~mm})\end{array}$ & $\begin{array}{c}\text { Absorção Lateral } \\
\left(\mathrm{kg} / \mathrm{m}^{2} / \mathrm{h}\right)\end{array}$ & Absorção Lateral (\%) \\
\hline \multirow{9}{*}{$\begin{array}{l}\text { Altura da } \\
\text { caixa }\end{array}$} & 01 & 0,573 & 0,375 & 5,7 \\
\hline & 02 & 0,558 & 0,367 & 5,4 \\
\hline & 03 & 0,570 & 0,404 & 6,0 \\
\hline & 04 & 0,567 & 0,379 & 5,6 \\
\hline & 05 & 0,563 & 0,497 & 7,3 \\
\hline & 06 & 0,555 & 0,446 & 6,6 \\
\hline & 07 & 0,563 & 0,399 & 5,8 \\
\hline & média & 0,564 & 0,410 & 6,1 \\
\hline & $\begin{array}{l}\text { Desvio- } \\
\text { padrão }\end{array}$ & 0,006 & 0,047 & 0,7 \\
\hline
\end{tabular}

*as espessuras apresentadas para cada corpo-de-prova é uma média de três leituras.

\subsubsection{Absorção de água pela face}

Para a determinação da absorção de água pela face foi utilizado o método descrito no item $c$ de 4.3 .1 do capítulo 4. O resultado para ambas as amostras foi menor que $0,1 \mathrm{~g} / \mathrm{m}^{2}$ a cada dois minutos.

\subsubsection{Absorção de água da embalagem inteira}

Para a determinação da absorção de água da embalagem inteira foi utilizado o método descrito no item $d$ de 4.3.1 do capítulo 4. Os resultados para as embalagens de leite e suco estão apresentados na Tabela 5.10 .

Tabela 5.10 - Absorção de água da embalagem inteira

\begin{tabular}{l|c|c|c|c}
\hline amostra & $\begin{array}{c}\text { Corpo-de- } \\
\text { prova }\end{array}$ & $\begin{array}{c}\text { Massa seca } \\
(\mathrm{g})\end{array}$ & $\begin{array}{c}\text { Massa úmida } \\
(\mathrm{g})\end{array}$ & Absorção (\%) \\
\hline \multirow{3}{*}{ Suco } & 01 & 38,96 & 80,73 & 107 \\
\cline { 2 - 5 } & 02 & 38,40 & 80,21 & 108 \\
\cline { 2 - 5 } & 03 & 38,71 & 79,33 & 105 \\
\hline \multirow{3}{*}{ Leite } & 01 & 28,30 & 48,63 & 72 \\
\cline { 2 - 5 } & 02 & 28,25 & 46,76 & 66 \\
\hline
\end{tabular}




\subsubsection{Identificação das camadas plásticas}

Para a identificação das camadas internas e externas de cada embalagem foi utilizada a técnica de espectrofotometria no infravermelho, conforme descrito no item $i$ de 4.3.1 do capítulo 4 .

A Figura 5.1 mostra um espectro de um polietileno para comparação (Sadtler, 1980) com os espectros obtidos nas Figuras 5.2, 5.3, 5.4 e 5.5 correspondentes de cada camada das amostras de leite e suco. Todos os espectros observam-se uma banda próxima de $2900 \mathrm{~cm}^{-1}$ devido ao estiramento $\mathrm{C}-\mathrm{H}$ e em $1470 \mathrm{~cm}^{-1}$ devido a vibração de deformação do $\mathrm{CH}_{2}$ acompanhada de um dubleto na região de 730 a $700 \mathrm{~cm}^{-1}$ indicativo do movimento de balanço do $\mathrm{CH}_{2}$.

Um dubleto forte e nítido na região de 730 a $700 \mathrm{~cm}^{-1}$ só está presente quando há unidades de etileno cristalino no polietileno, como no caso de polietilenos de alta densidade. Uma banda apenas nesta mesma região é observada no polietileno amorfo. Pode-se admitir que os espectros correspondentes as amostras são característicos de polietileno linear que apresenta um grau de cristalinidade superior ao polietileno de baixa densidade (amorfo).

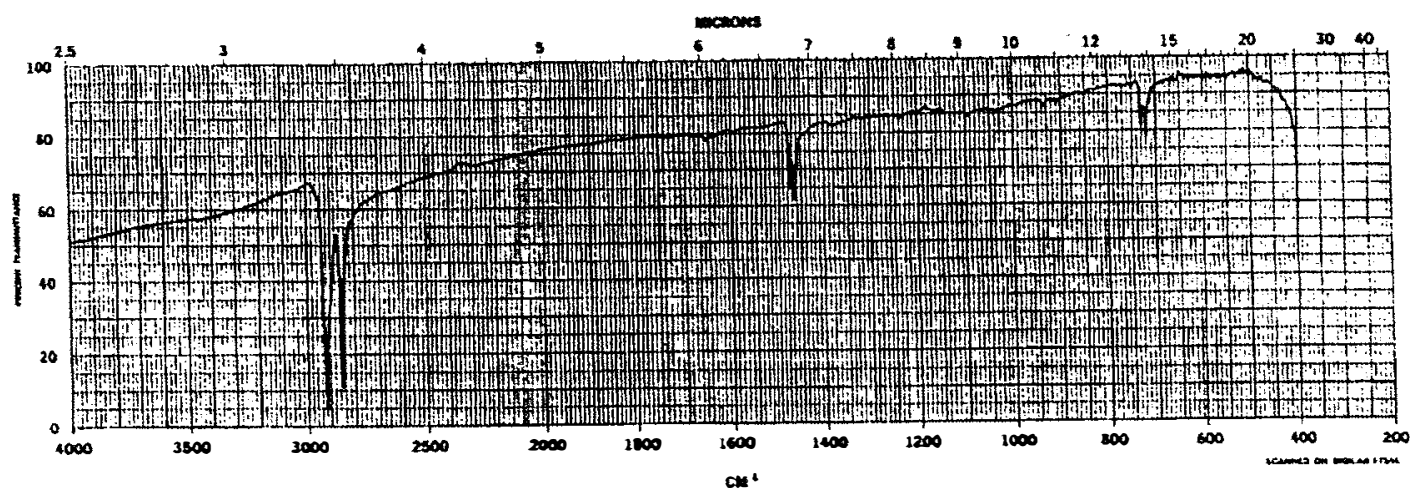

Figura 5.1 - Espectro de um polietileno 


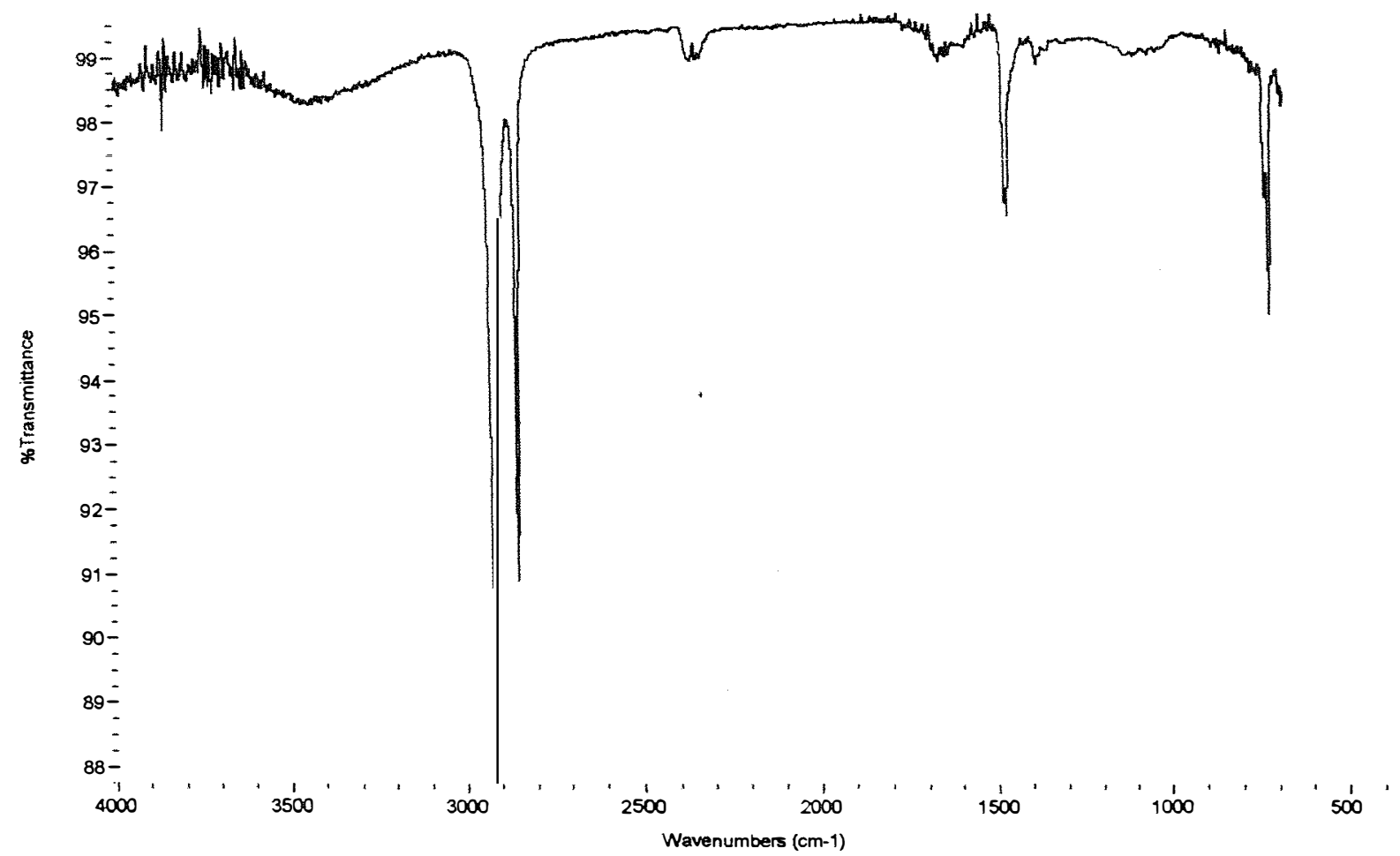

Figura 5.2 - Camada externa da amostra de leite - polietileno linear

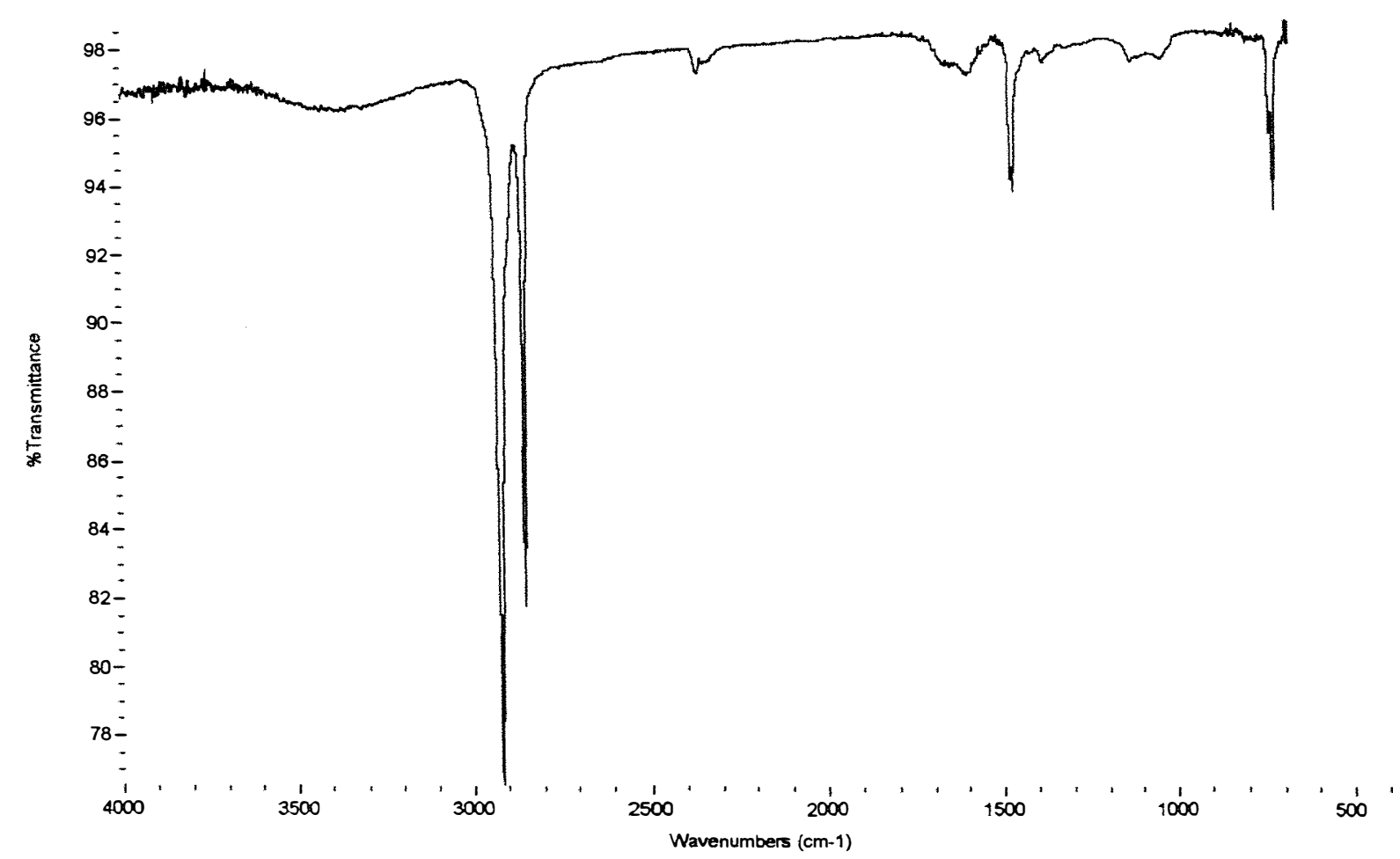

Figura 5.3 - Camada interna da amostra de leite - polietileno linear 


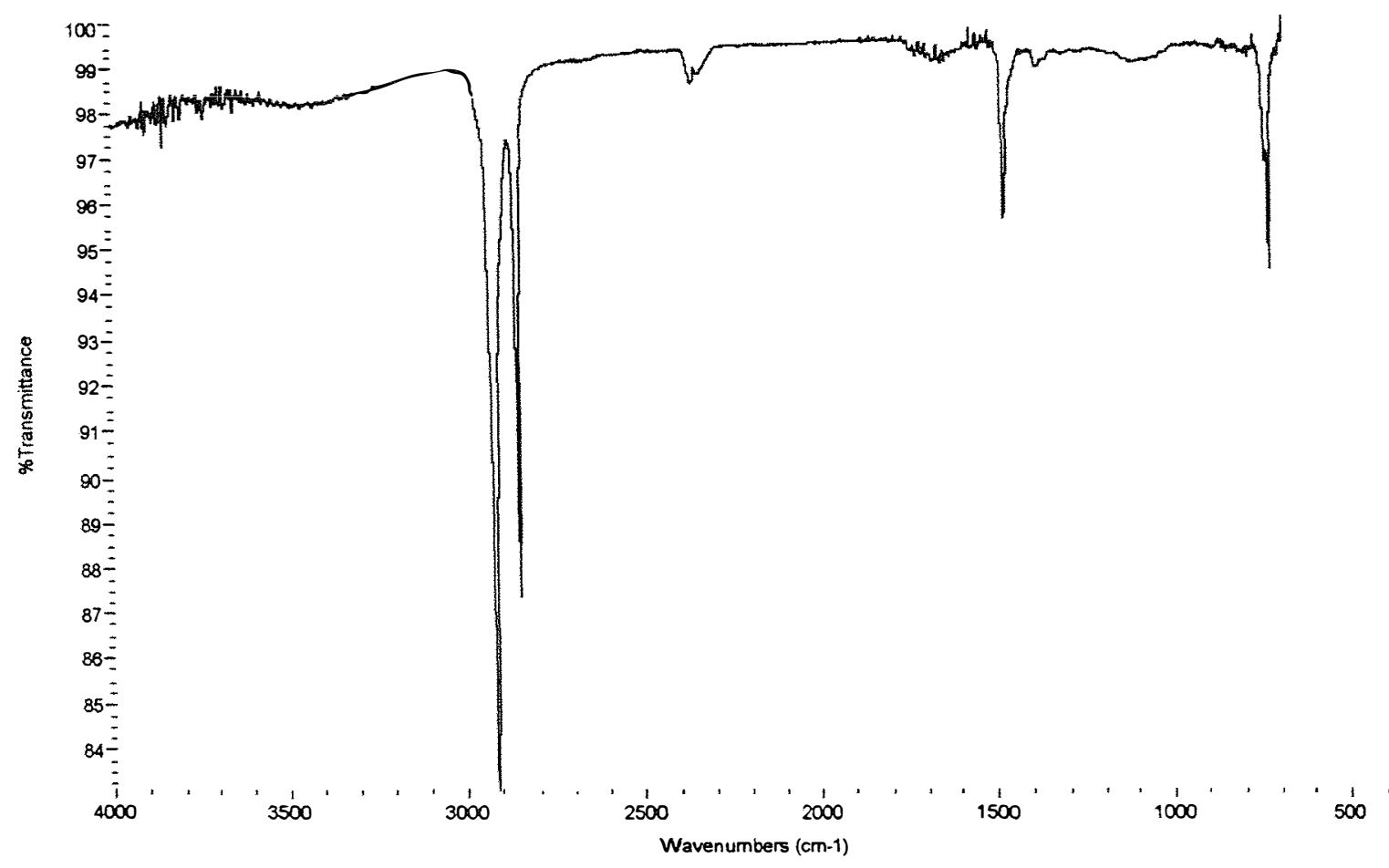

Figura 5.4 - Camada externa da amostra de suco - polietileno linear

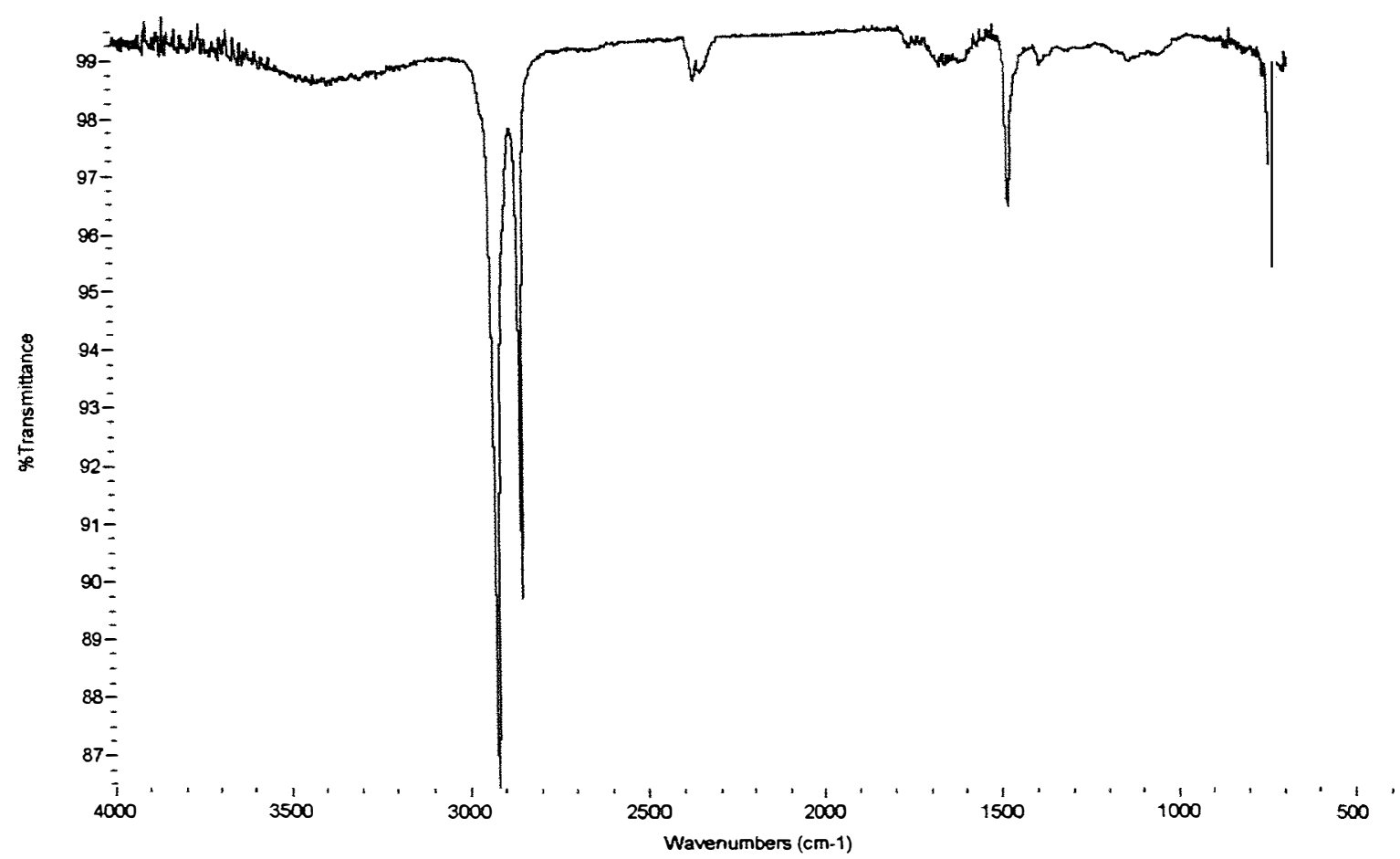

Figura 5.5 - Camada interna da amostra de suco - polietileno linear 


\subsection{Ensaios de Degradabilidade}

A degradação das amostras, como foi visto na literatura, pode ser acompanhada entre outros aspectos, pela perda de massa, exame físico da amostra, alteração na estrutura química, ou ainda, com o decaimento de um percentual de resistência mecânica original (por ex. $50 \%$ de resistência à tração do material criginal comprometida).

A degradabilidade das embalagens multicamada foram acompanhadas, sempre que possivel, com base nos parâmetros de massa, resistência mecânica e análise visual.

A degradabilidade das camadas plásticas (interna e externa) das embalagens multicamada, foram analisadas, também, quanto a alteração na estrutura química.

\subsubsection{Degradabilidade por imersão em chorume}

Inicialmente foi realizada a caracterização do chorume coletado em 25.03.1998 na lagoa do aterro de Vila Abertina, como citado anteriormente. Uma amostra deste chorume (quatro litros) foi analisado pelo Laboratório de Fermentações Industriais do Agrupamento de Biotecnologia do IPT. No dia 21.10. 1998 , ao final do ensaio de degradação no chorume, foi coletada outra amostra de cinco litros da cuba de inox e enviada para a realização das mesmas determinações. Os resultados destas análises estão apresentados na Tabela 5.11.

Nesta mesma Tabela, estão incluídos dados históricos do chorume da lagoa do aterro de Vila Abertina que foram cedidos pela empresa 
"Queiroz Galvão", responsável pela coleta e análises periódicas da lagoa do aterro.

Tabela 5.11 - Características do chorume

\begin{tabular}{|c|c|c|c|c|c|c|}
\hline & \multirow{2}{*}{\multicolumn{4}{|c|}{$\begin{array}{c}\text { Dados históricos } \\
\end{array}$}} & \multirow{2}{*}{\multicolumn{2}{|c|}{ Dados da amostra }} \\
\hline & & & & & & \\
\hline & 08/07/97 & 05/08/97 & $30 / 09 / 97$ & 09/10/97 & março/98 & $27 / 11 / 98$ \\
\hline alcalinidade $\left(\mathrm{mg} \mathrm{CaCO}_{3} / \mathrm{l}\right)$ & & & & & 4300 & 4295 \\
\hline Sólidos Totais $(\mathrm{g} / \mathrm{l})$ & 10,790 & 11,765 & 11,885 & 9,745 & 4,60 & 19,0 \\
\hline Sólidos Fixos Totais $(\mathrm{g} / \mathrm{l})$ & 6,940 & 7,820 & 8,180 & 6,575 & 2,97 & 14,6 \\
\hline Sólidos Voláteis Totais $(\mathrm{g} / \mathrm{l})$ & 3,850 & 3,945 & 3,705 & 3,17 & 1,63 & 4,38 \\
\hline Sólidos Dissolvidos S. Totais (mg/l) & 10390 & 11545 & 11415 & 9550 & & \\
\hline Sólidos Suspensos Totais $(\mathrm{g} / \mathrm{l})$ & 0,400 & 0,220 & 0,470 & 0,195 & 0,152 & 0,820 \\
\hline Sólidos Sedimentáveis (mg/l) & 0,8 & 0,4 & 1,3 & 0,2 & & \\
\hline Sólidos Suspensos Fixos $(\mathrm{g} / \mathrm{l})$ & & & & & 0,066 & 0,300 \\
\hline Sólidos Suspensos Voláteis ( $\mathrm{g} / \mathrm{l})$ & & & & & 0,086 & 0,520 \\
\hline$\overline{\mathrm{DBO}}-5 \mathrm{D}, 20 \mathrm{C}(\mathrm{mg} / \mathrm{l})$ & 500 & 2820 & 1710 & - & 290,6 & 207,0 \\
\hline$\overline{D Q O}(\mathrm{mg} / \mathrm{l})$ & 4160 & 5530 & 6510 & $-\ldots$ & 3304,5 & 8578 \\
\hline$\overline{\mathrm{pH}}$ & 8,60 & 8,59 & 8,56 & 8,69 & 8,32 & 9,34 \\
\hline
\end{tabular}

Foi observado que o chorume no final do ensaio de degradabilidade, ainda na cuba de aço inoxidável, a presença de materiais de embalagem (fibras principalmente). O chorume coletado, cerca de quarenta litros, foi suficiente para a realização do ensaio.

As embalagens multicamada, inicialmente, flutuavam no chorume, complicando a interação uniforme de todas as embalagens com o chorume (Foto 5). Foram realizados controle de temperatura e pH, utilizando o termômetro de bulbo e papel indicador de pH. Estas determinações estão apresentadas na Tabela 5.12. Foi colocado chorume para completar o volume da cuba sempre que necessário.

Tabela 5.12 - Determinações de temperatura e pH para o controle do banho

\begin{tabular}{c|c|c|c|c|c|c|c|c|}
\cline { 2 - 9 } \multicolumn{1}{c|}{} & \multicolumn{7}{c}{ Datas (1998) } \\
\hline Parâmetro & 17.04 & 23.04 & 15.05 & 09.06 & 24.07 & 02.09 & 08.09 & 02.10 \\
\hline $\mathrm{pH}$ & 8,0 & 8,0 & 8,0 & 8,0 & 8,5 & 8,5 & 8,5 & 8,5 \\
\hline Temperatura $\left({ }^{\circ} \mathrm{C}\right)$ & 50 & 49 & 50 & 47 & 45 & 45 & 49 & 51 \\
\hline
\end{tabular}




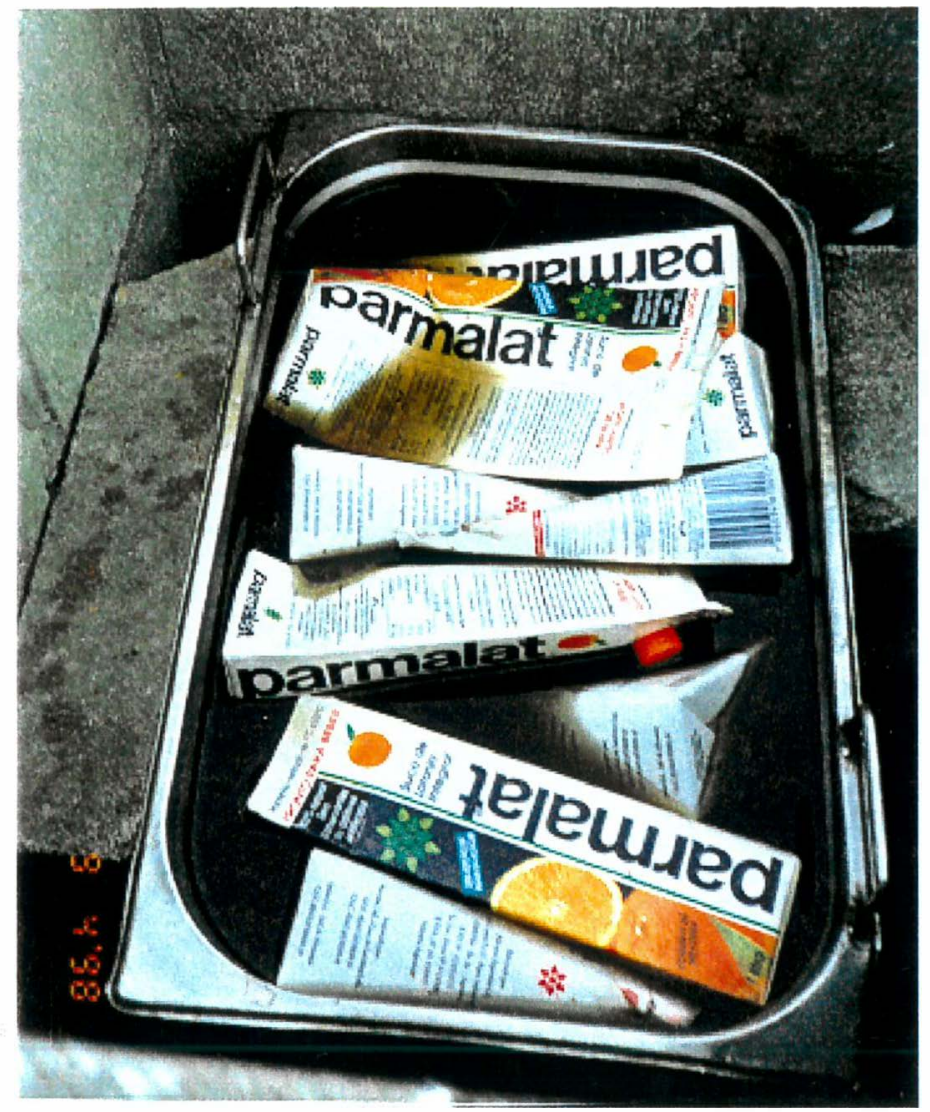

Foto 5 - Cuba contendo chorume e embalagens 
As embalagens multicamadas de suco e leite foram retiradas a cada período e submetidas ao ensaio de variação de massa de acordo com a metodologia descrita no item e de 4.3.1 do capítulo 4.

Os resultados da variação de massa devido a degradação em ambiente simulativo ao aterro (chorume) estão apresentados nas Tabelas 5.13 e 5.14, onde:

Corpo-de-prova

01

02

03

04

05

06
Tempo de exposição (semanas)

5

10

14

19

23

27

Tabela 5.13 - Variação de massa da amostra de Suco.

\begin{tabular}{c|c|c|c|c|c|c}
\hline $\begin{array}{c}\text { Corpo- } \\
\text { de- } \\
\text { prova }\end{array}$ & $\begin{array}{c}\text { Massa inicial } \\
\text { seca }(\mathbf{g})\end{array}$ & $\begin{array}{c}\text { Massa inicial } \\
\text { úmida }(\mathrm{g})\end{array}$ & $\begin{array}{c}\text { Massa } \\
\text { úmida após } \\
\text { o tempo de } \\
\text { exposição } \\
(\mathbf{g})\end{array}$ & $\begin{array}{c}\text { Variação } \\
\text { úmida } \\
(\mathbf{g})\end{array}$ & $\begin{array}{c}\text { Massa seca } \\
\text { após o tempo } \\
\text { de exposição } \\
(\mathbf{g})\end{array}$ & $\begin{array}{c}\text { Variação } \\
\text { seca }(\mathbf{g})\end{array}$ \\
\hline 01 & 39,49 & 43,46 & 70,00 & 26,54 & 56,76 & 17,27 \\
\hline 02 & 39,30 & 43,15 & 77,20 & 34,05 & 65,33 & 26,03 \\
\hline 03 & 39,45 & 43,32 & 64,33 & 21,01 & 43,64 & 4,19 \\
\hline 04 & 39,54 & 48,79 & 67,42 & 18,63 & 38,57 & $-0,97$ \\
\hline 05 & 39,59 & 44,66 & 83,59 & 38,93 & 41,00 & 1,41 \\
\hline 06 & 39,19 & 43,59 & 63,6 & 20,01 & 46,74 & 7,55 \\
\hline
\end{tabular}

Tabela 5.14 - Variação de massa da amostra de Leite

\begin{tabular}{c|c|c|c|c|c|c}
\hline $\begin{array}{c}\text { Corpo- } \\
\text { de- } \\
\text { prova }\end{array}$ & $\begin{array}{c}\text { Massa inicial } \\
\text { seca (g) }\end{array}$ & $\begin{array}{c}\text { Massa inicial } \\
\text { úmida (g) }\end{array}$ & $\begin{array}{c}\text { Massa } \\
\text { úmida após } \\
\text { o tempo de } \\
\text { exposição } \\
(\mathbf{g})\end{array}$ & $\begin{array}{c}\text { Variação } \\
\text { úmida } \\
(\mathbf{g})\end{array}$ & $\begin{array}{c}\text { Massa seca } \\
\text { após o tempo } \\
\text { de exposição } \\
(\mathbf{g})\end{array}$ & $\begin{array}{c}\text { Variação } \\
\text { seca (g) }\end{array}$ \\
\hline 01 & 31,58 & 33,92 & 71,00 & 37,08 & 21,20 & $-10,38$ \\
\hline 02 & 31,29 & 34,27 & 79,60 & 45,33 & 15,55 & $-15,74$ \\
\hline 03 & 31,76 & 36,11 & 72,60 & 36,49 & 25,80 & $-5,96$ \\
\hline 04 & 31,00 & 34,48 & 83,35 & 48,87 & 35,25 & 4,25 \\
\hline 05 & 31,82 & 34,72 & 77,60 & 42,88 & 17,06 & $-14,76$ \\
\hline 06 & 30,80 & 35,57 & 71,27 & 35,70 & 15,60 & $-15,20$ \\
\hline
\end{tabular}


Após a determinação de variação de massa, estas amostras foram submetidas ao exame visual. As Fotos 6 e 7 mostram os aspectos de deterioração comparativamente das amostras de leite e suco e a cada período de imersão no chorume. $O$ aspecto visual mostra uma deterioração da amostra de leite mais acentuada do que da amostra de suco para este período de degradação em imersão no chorume.

As amostras foram submetidas ao ensaio de tração, sendo que para amostra de suco utilizou-se o método descrito no item $f$ de 4.3 .1 do capítulo 4 e para a amostra de leite foi utilizado os mesmos parâmetros de ensaio (velocidade da máquina), exceto que não havia nenhum espaçamento entre as garras. Foi utilizado um dispositivo de tração, denominado zero-span que não permitia nenhum espaçamento entre garras.

As amostras de embalagem de leite, a partir de 3 meses de imersão no chorume, estavam com enrrugamentos que não permitiam a retirada de corpos-de-prova em formatos de tiras com comprimento mínimo de $200 \mathrm{~mm}$ e $25 \mathrm{~mm}$ de largura, mas utilizando o dispositivo zero-span o corpo-deprova apresentava no máximo um centímetro de comprimento e $15 \mathrm{~mm}$ de largura. Estas dimensões facilitaram a retirada de um maior número de corposde-prova da mesma amostra e permitiu analisar a dispersão dos resultados de tensão de ruptura de cada uma. Entretanto, o dispositivo zero-span impede o cálculo do alongamento na ruptura.

Os resultados de tensão de ruptura, alongamento na ruptura e módulo de elasticidade da amostra de suco estão apresentados na Tabela 5.15 . 


\section{Degradação \\ no Chorume}

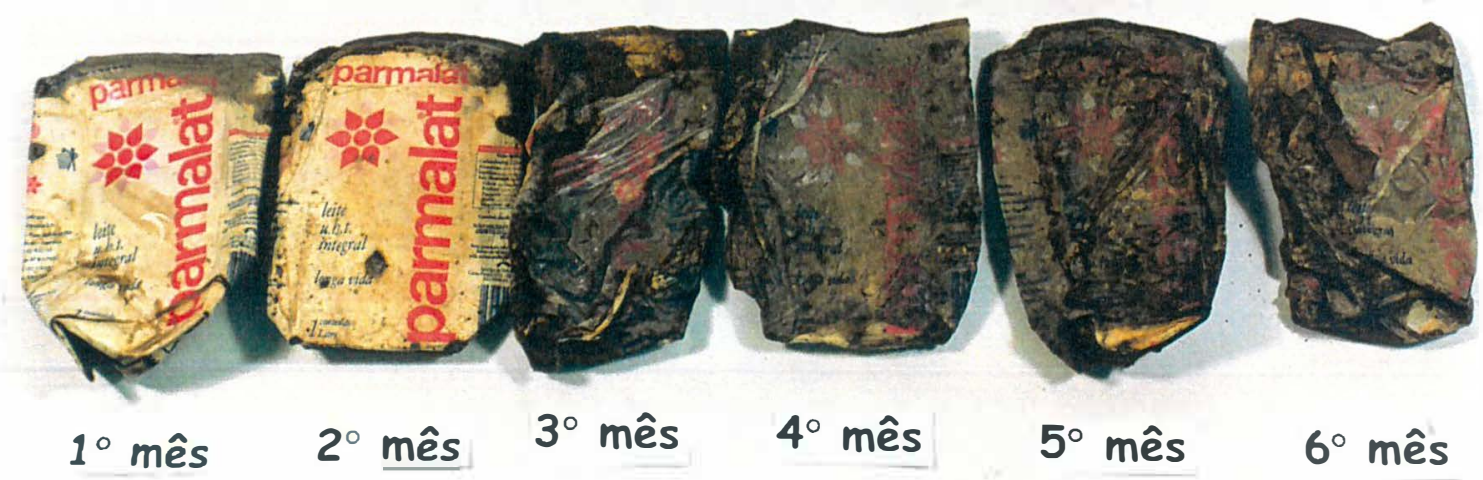

Foto 6 - Seqüência do período total de degradação em chorume das embalagens de leite.

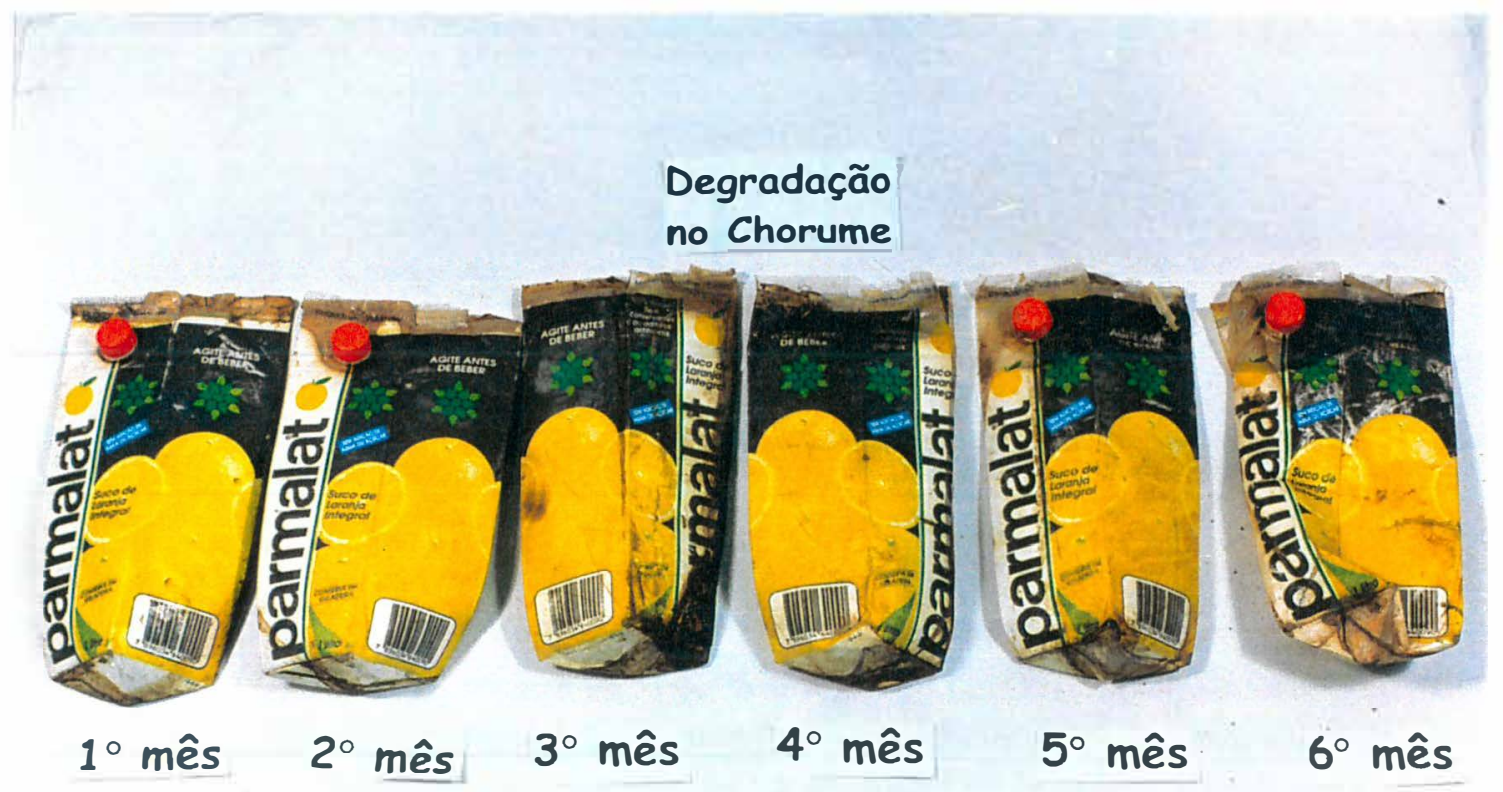

Foto 7 - Seqüência do período total de degradação em chorume das embalagens de suco. 
Tabela 5.15 - Resultados do ensaio de tração - Amostra envelhecida por imersão no chorume - Suco

\begin{tabular}{|c|c|c|c|c|}
\hline $\begin{array}{l}\text { Tempo de } \\
\text { exposição }\end{array}$ & $c p$ & $\begin{array}{c}\text { Alongamento } \\
\text { na ruptura } \\
(\%)\end{array}$ & $\begin{array}{l}\text { Tensão de } \\
\text { ruptura } \\
\text { (MPa) }\end{array}$ & $\begin{array}{l}\text { Módulo de } \\
\text { Elasticidade } \\
\text { (MPa) }\end{array}$ \\
\hline \multirow{3}{*}{1 mês } & 01 & 8,7 & 12,2 & 327 \\
\hline & 02 & 9,0 & 12,6 & 334 \\
\hline & 03 & 8,9 & 12,0 & 314 \\
\hline \multirow{3}{*}{2 meses } & 01 & 8,6 & 11,8 & 311 \\
\hline & 02 & 8,0 & 11,5 & 308 \\
\hline & 03 & 6,2 & 9,4 & 294 \\
\hline \multirow{3}{*}{3 meses } & 01 & 7,4 & 11,3 & 307 \\
\hline & 02 & 8,1 & 12,0 & 289 \\
\hline & 03 & 8,0 & 11,3 & 318 \\
\hline \multirow{3}{*}{4 meses } & 01 & 8,5 & 12,9 & 318 \\
\hline & 02 & 7,6 & 11,4 & 298 \\
\hline & 03 & 7,0 & 11,1 & 302 \\
\hline \multirow{3}{*}{5 meses } & 01 & 7,0 & 10,1 & 280 \\
\hline & 02 & 8,4 & 10,9 & 285 \\
\hline & 03 & 7,5 & 10,5 & 258 \\
\hline \multirow{3}{*}{6 meses } & 01 & 7,5 & 10,0 & 255 \\
\hline & 02 & 5,8 & 9,1 & 238 \\
\hline & 03 & 4,7 & 7,2 & 232 \\
\hline
\end{tabular}

A Tabela 5.16 mostra os resultados do ensaio de tração referente ao primeiro e segundo meses após imersão no chorume da amostra de leite. Para estas duas amostras não foi necessário utilizar o dispositivo "zerospan".

Tabela 5.16 - Resultados do ensaio de tração - Amostra envelhecida por imersão no chorume - Leite

\begin{tabular}{l|c|c|c|c|c}
\hline $\begin{array}{l}\text { Tempo de } \\
\text { exposição }\end{array}$ & $\mathrm{cp}$ & $\begin{array}{c}\text { Largura } \\
(\mathrm{mm})\end{array}$ & $\begin{array}{c}\text { Espessura } \\
(\mathrm{mm})\end{array}$ & $\begin{array}{c}\text { Alongamento } \\
\text { na ruptura } \\
(\%)\end{array}$ & $\begin{array}{c}\text { Tensão de } \\
\text { ruptura } \\
(\mathrm{MPa})\end{array}$ \\
\hline \multirow{3}{*}{1 mês } & 01 & 16 & 0,54 & - & 9,8 \\
\cline { 2 - 6 } & 02 & 20 & 0,54 & 3,7 & 7,0 \\
\hline \multirow{3}{*}{2 meses } & 03 & 20 & 0,54 & 4,6 & 8,3 \\
\cline { 2 - 6 } & 01 & 20 & 0,58 & 2,6 & 4,7 \\
\cline { 2 - 6 } & 02 & 20 & 0,58 & 3,6 & 9,4 \\
\cline { 2 - 6 } & 03 & 20 & 0,58 & 2,9 & 5,6 \\
\hline
\end{tabular}


A Tabela 5.17 mostra os resultados do ensaio de tração referente ao terceiro, quarto, quinto e sexto meses após imersão no chorume da amostra de leite. Para estas amostras foi utilizado o dispositivo "zero-span".

Tabela 5.17 - Resultados do ensaio de tração - Amostra envelhecida por imersão no chorume - Leite

\begin{tabular}{|c|c|c|c|c|c|c|c|c|c|c|c|c|c|}
\hline \multirow{2}{*}{$\begin{array}{c}\text { Amos- } \\
\text { tra }\end{array}$} & \multirow[t]{2}{*}{ Medida } & \multicolumn{10}{|c|}{ Corpo-de-prova } & \multirow[t]{2}{*}{$\mathrm{M}$} & \multirow[t]{2}{*}{ DP } \\
\hline & & 01 & 02 & 03 & 04 & 05 & 06 & 07 & 08 & 09 & 10 & & \\
\hline \multirow{2}{*}{$\begin{array}{c}3 \\
\text { meses }\end{array}$} & esp. (mm) & 0,50 & 0,50 & 0,52 & 0,52 & 0,42 & 0,24 & 0,26 & 0,30 & 0,30 & 0,28 & 0,38 & 0,12 \\
\hline & T.R. (MPa) & 11,0 & - & 18,6 & 10,7 & 4,5 & 8,4 & 6,0 & 3,9 & 6,8 & 7,5 & 8,6 & 4,5 \\
\hline \multirow{2}{*}{$\begin{array}{c}4 \\
\text { meses }\end{array}$} & esp. (mm) & 0,40 & 0,32 & 0,30 & 0,32 & 0,38 & 0,32 & 0,38 & 0,38 & 0,34 & 0,32 & 0,35 & 0,04 \\
\hline & T. R. (MPa) & 9,5 & 7,8 & 7,6 & 5,9 & 8,4 & 5,9 & 7,4 & 3,4 & 7,3 & 8,2 & 7,1 & 1,7 \\
\hline \multirow{2}{*}{$\begin{array}{c}5 \\
\text { meses }\end{array}$} & esp. (mm) & 0,28 & 0,28 & 0,28 & 0,24 & 0,24 & 0,22 & 0,24 & 0,26 & 0,32 & 0,20 & 0,26 & 0,04 \\
\hline & T. R. (MPa) & 6,5 & 6,5 & 6,8 & 7,1 & 8,4 & 8,9 & 8,7 & 8,3 & 4,7 & 9,5 & 7,6 & 1,5 \\
\hline \multirow{2}{*}{$\begin{array}{c}6 \\
\text { meses }\end{array}$} & esp. (mm) & 0,30 & 0,36 & 0,42 & 0,34 & 0,32 & 0,30 & 0,30 & 0,28 & 0,38 & 0,32 & 0,33 & 0,04 \\
\hline & T.R. (MPa) & 10,2 & 9,8 & 2,6 & 9,6 & 10,0 & 10,0 & 8,7 & 8,6 & 9,1 & 8,6 & 8,7 & 2,2 \\
\hline
\end{tabular}

Onde: esp. = espessura; T.R. = tensão de ruptura; $M=$ média ; $D P=$ desviopadrão.

As alterações na estrutura química das camadas internas e externas das amostras de leite e de suco verificadas através de espectrofotometria no infravermelho (método descrito no item $i$ de 4.3.1 do capítulo 4) após seis meses de imersão em chorume, estão apresentadas nas Figuras 5.6, 5.7, 5.8 e 5.9.

Em geral, observa-se nestes espectros o surgimento de bandas nas regiões de $1700 \mathrm{~cm}^{-1}$ e $1000 \mathrm{~cm}^{-1}$ que não pertencem ao espectro de um polietileno, conforme visto na Figura 5.1.

A banda em $1000 \mathrm{~cm}^{-1}$ pode ser caracterizada como um grupo vinil com isomeria trans e a banda em $1700 \mathrm{~cm}^{-1}$ como um grupo carbonila (Sadtler, 1980). 
105

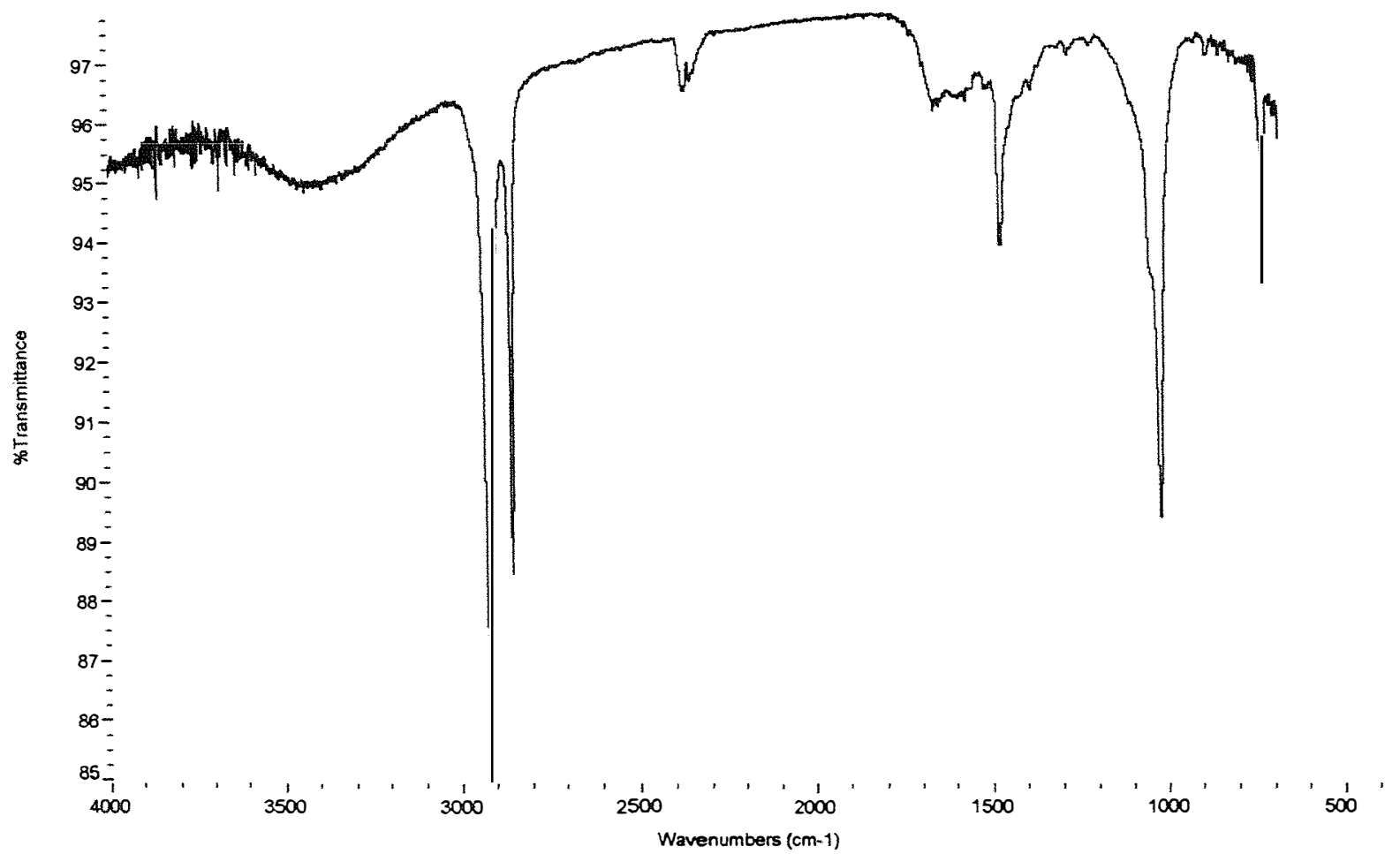

Figura 5.6 - Camada externa da amostra de leite após seis meses de imersão no chorume - polietileno oxidado

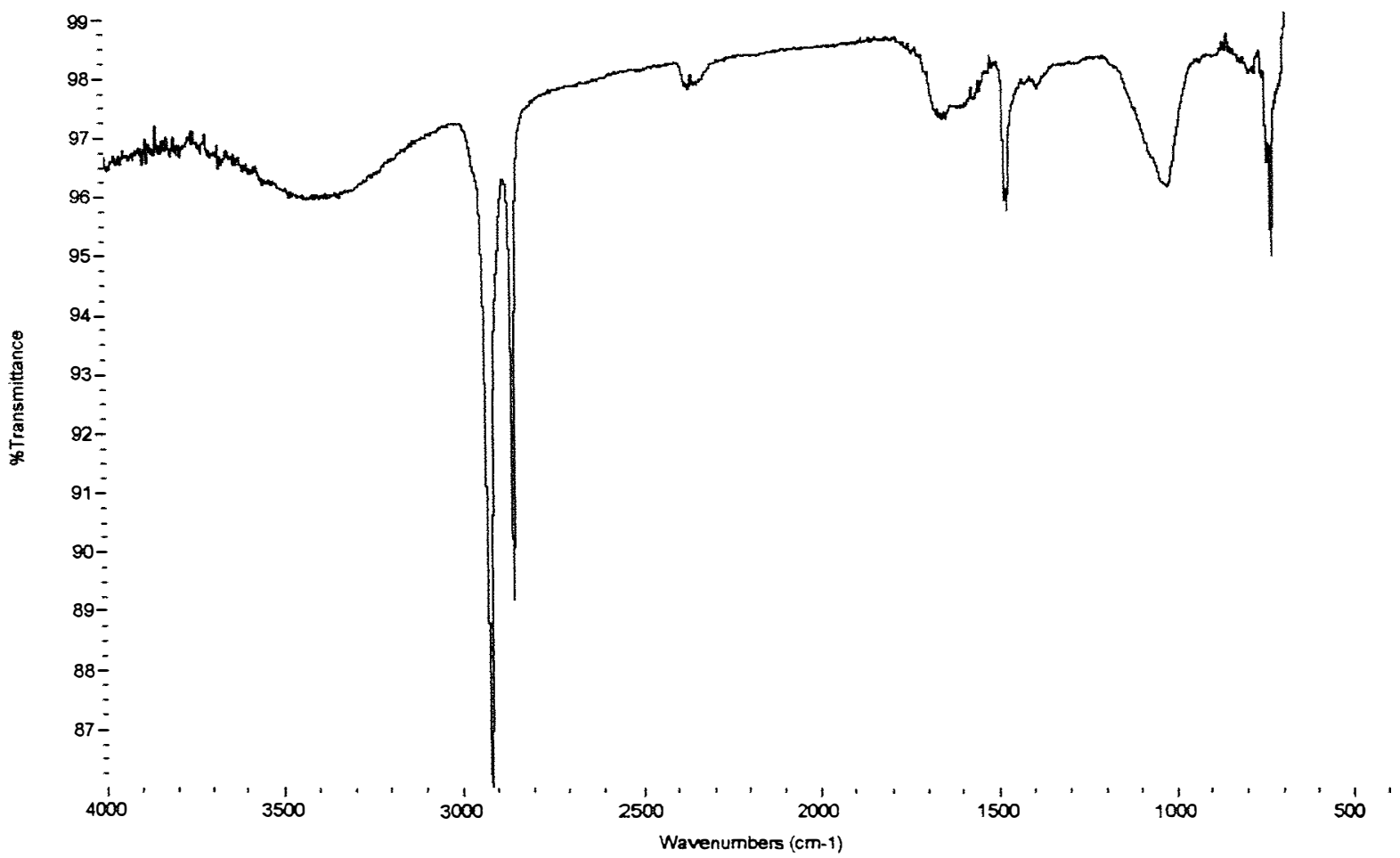

Figura 5.7 - Camada interna da amostra de leite após seis meses de imersão no chorume - polietileno oxidado 


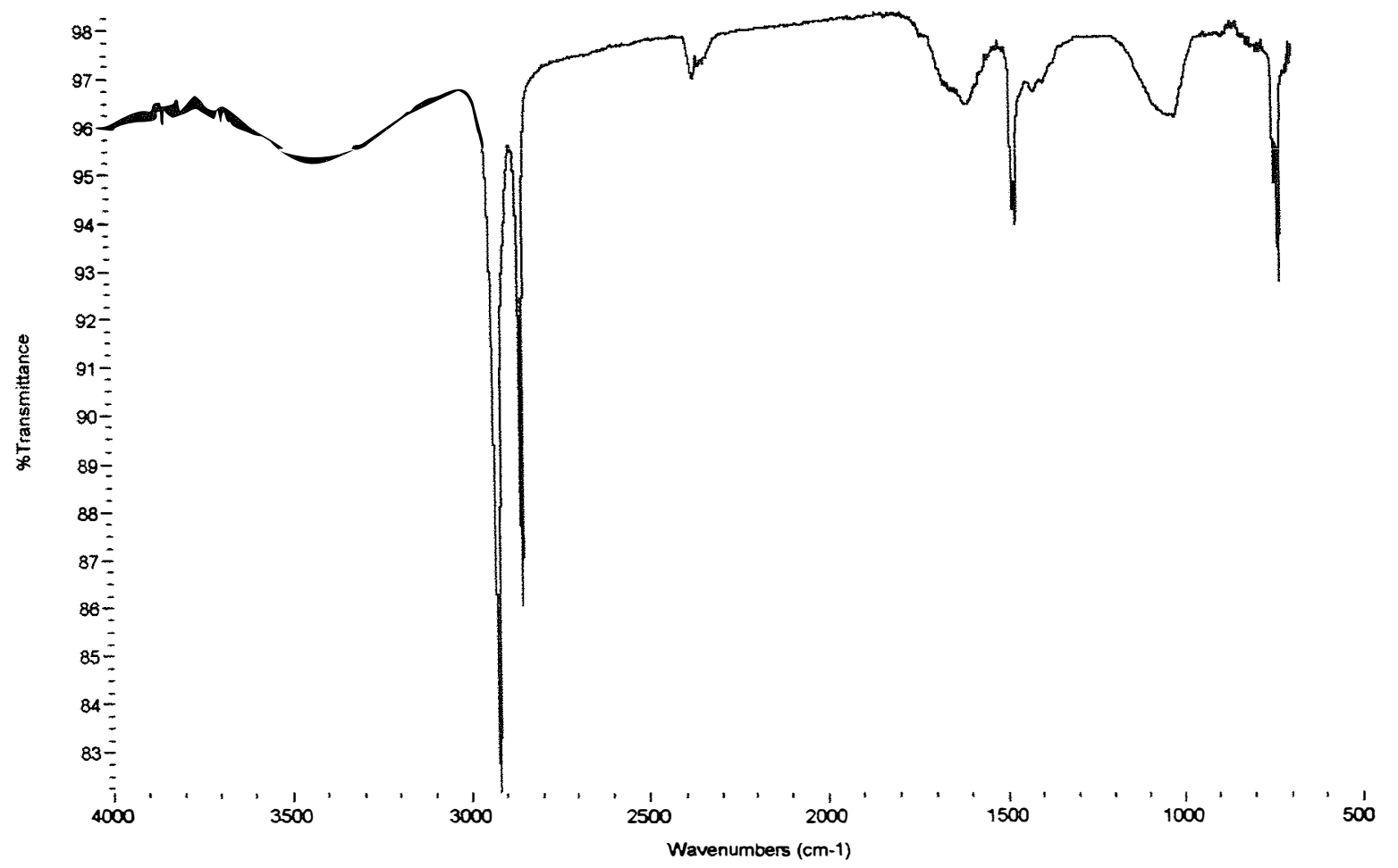

Figura 5.8 - Camada externa da amostra de suco após seis meses de imersão no chorume - polietileno oxidado

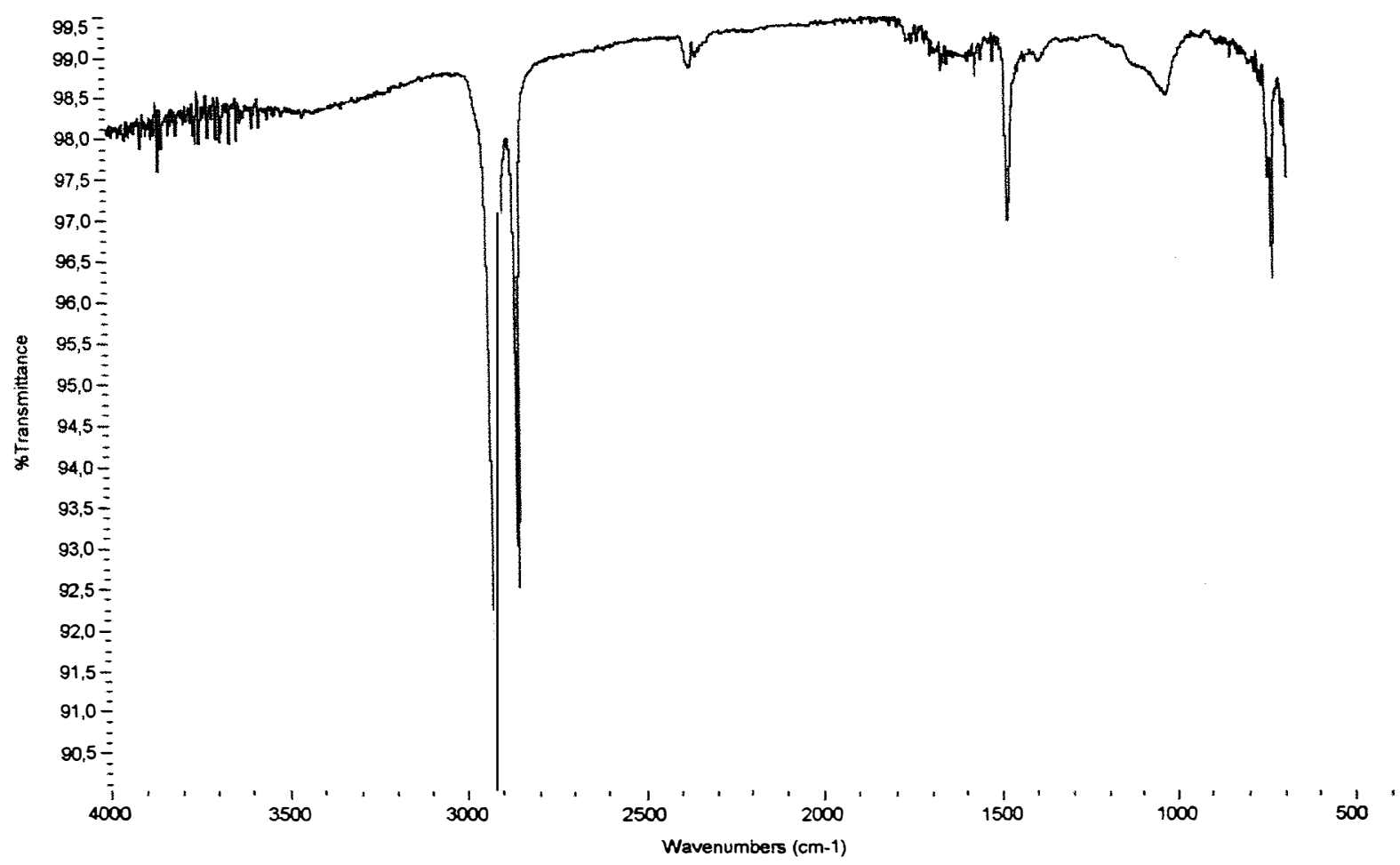

Figura 5.9 - Camada interna da amostra de suco após seis meses de imersão no chorume - polietileno oxidado 


\subsubsection{Degradabilidade por exposição à luz ultravioleta}

As amostras submetidas a luz ultravioleta e condensação em períodos altemados sob temperatura controlada, conforme o método descrito no item a de 4.3.2 do capítulo 4, apresentaram aspecto visual alterado em relação a original, principalmente a amostra de suco (Fotos 8 e 9).

A estimativa de perda de cor foi analisada pelo método descrito no item $j$ de 4.3 .1 do capítulo 4. Os resultados calculados da estimativa de perda de cor pelo efeito da exposição à radiação ultravioleta e condensação estão apresentados na Tabela 5.18.

Tabela 5.18 - Estimativa de perda de cor representada por $\mathrm{DE}^{*}$ de ambas as amostras

\begin{tabular}{c|c|c}
\hline $\begin{array}{c}\text { Tempo de exposição } \\
\text { (horas) }\end{array}$ & DE da Amostra Leite & DE da Amostra Suco \\
\hline 12 & 3,09 & $11,55^{\star \star}$ \\
\hline 24 & 2,09 & 3,06 \\
\hline 48 & 5,23 & 8,20 \\
\hline 72 & 5,18 & 14,37 \\
\hline 110 & 10,11 & 30,02 \\
\hline 200 & 10,38 & 39,53 \\
\hline
\end{tabular}

* $\mathrm{DE}=$ diferença de cor entre as amostras envelhecidas e a amostra original.

** este valor não será considerado para análise dos resultados, porque provavelmente esta amostra já estava com a cor originalmente afetada. A causa provável deve ter ocorrido na fabricação da embalagem.

As amostras multicamadas de suco e leite após a exposição à luz ultravioleta foram submetidas aos ensaios de determinação da gramatura para analisar a perda de massa e aos ensaios de determinação de rigidez Lhomargy e de determinação da resistência à tração para avaliar a perda de resistência mecânica. Os métodos de ensaio utilizados foram os descritos nos itens $g$, $b$ e $f$ em 4.3 .1 do capítulo 4. 


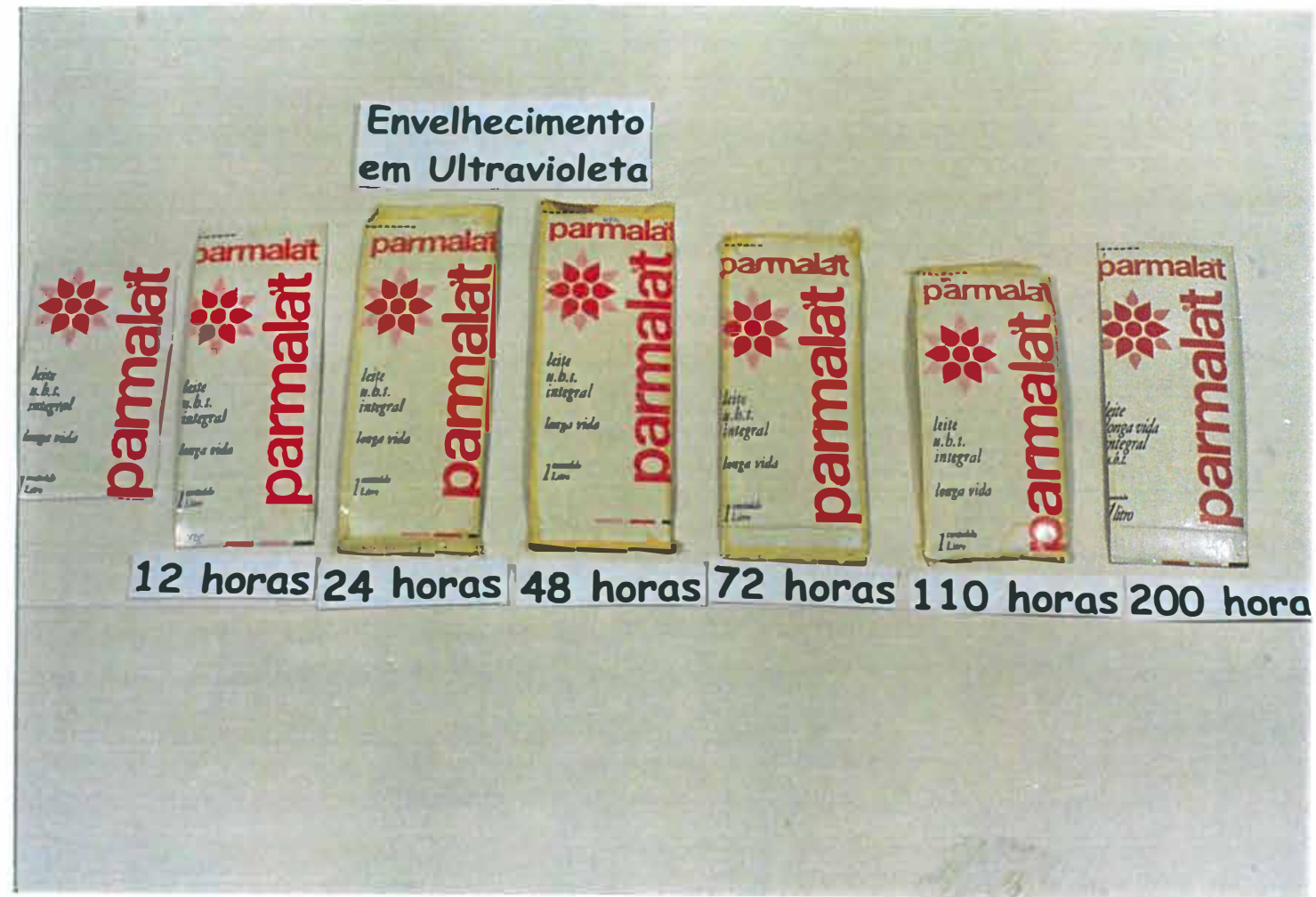

Foto 8 - Seqüência do período total de degradação em radiação ultravioleta e condensação das embalagens de leite.

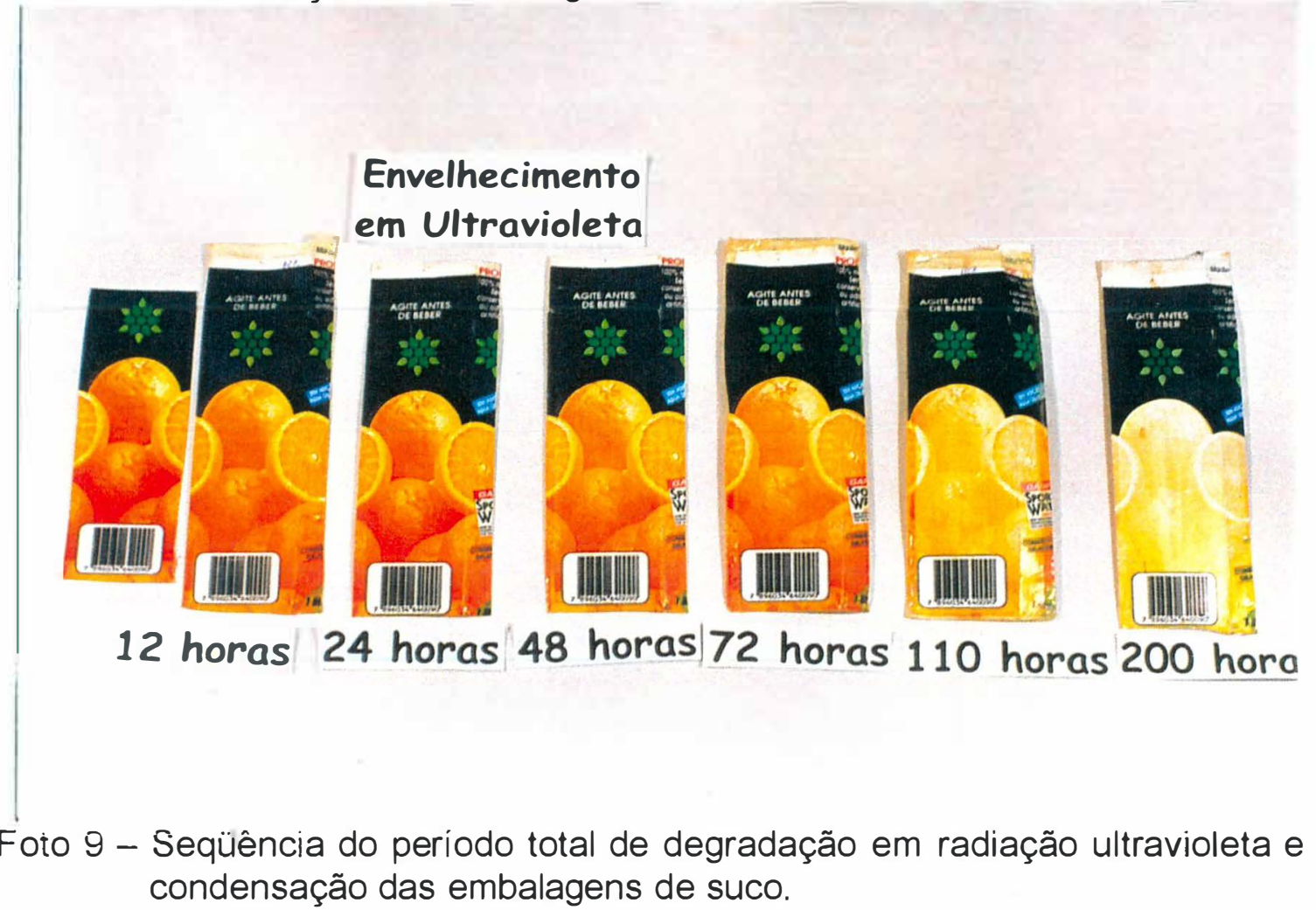


A Tabela 5.19 apresenta os resultados de gramatura de ambas as amostras.

Tabela 5.19 - Gramatura das amostras após exposição à luz ultravioleta $\left(\mathrm{g} / \mathrm{m}^{2}\right)$.

\begin{tabular}{c|c|c}
\hline $\begin{array}{c}\text { Tempo } \\
\text { (horas) }\end{array}$ & Amostra Suco & Amostra Leite \\
\hline 12 & 433 & 374 \\
\hline 24 & 421 & 358 \\
\hline 48 & 426 & 360 \\
\hline 72 & 423 & 355 \\
\hline 110 & 423 & 356 \\
\hline 200 & 435 & 366 \\
\hline
\end{tabular}

Os resultados encontrados de rigidez Lhomargy para cada amostra retirada nos períodos pré-estabelecidos estão apresentados nas Tabelas 5.20 e 5.21 .

Tabela 5.20 - Resultados do ensaio de rigidez Lhomargy - Amostra envelhecida na luz ultravioleta - Leite

\begin{tabular}{l|c|r|r|r|r}
\hline $\begin{array}{l}\text { Tempo de } \\
\text { exposição }\end{array}$ & $\mathrm{cp}$ & $\begin{array}{c}\text { Espessura } \\
(\mathrm{mm})\end{array}$ & $\begin{array}{c}\text { Gramatura } \\
\left(\mathrm{g} / \mathrm{m}^{2}\right)\end{array}$ & $\begin{array}{c}\text { Rigidez } \\
\text { Lhomargy } \\
(\mathrm{N} . \mathrm{mm})\end{array}$ & $\begin{array}{c}\text { Módulo de } \\
\text { Elasticidade } \\
\left(\mathrm{N} / \mathrm{mm}^{2}\right)\end{array}$ \\
\hline \multirow{3}{*}{12 horas } & 01 & 0,520 & 379 & 47,5 & 4056 \\
\hline \multirow{3}{*}{24 horas } & 02 & 0,520 & 384 & 50,4 & 4303 \\
\cline { 2 - 7 } & 02 & 0,530 & 362 & 54,1 & 4362 \\
\hline \multirow{3}{*}{48 horas } & 01 & 0,540 & 362 & 51,9 & 3954 \\
\hline \multirow{3}{*}{72 horas } & 01 & 0,525 & 362 & 51,8 & 4299 \\
\hline \multirow{3}{*}{110 horas } & 02 & 0,540 & 366 & 52,5 & 3999 \\
\hline \multirow{3}{*}{200 horas } & 01 & 0,530 & 361 & 61,3 & 4944 \\
\cline { 2 - 7 } & 02 & 0,530 & 359 & 49,3 & 3973 \\
\cline { 2 - 7 } & 02 & 0,535 & 362 & 56,5 & 4426 \\
\hline
\end{tabular}


Tabela 5.21 - Resultados do ensaio de rigidez Lhomargy - Amostra envelhecida na luz ultravioleta - Suco

\begin{tabular}{l|c|r|r|r|r}
\hline $\begin{array}{c}\text { Tempo de } \\
\text { exposição }\end{array}$ & $\mathrm{cP}$ & $\begin{array}{c}\text { Espessura } \\
(\mathrm{mm})\end{array}$ & $\begin{array}{c}\text { Gramatura } \\
\left(\mathrm{g} / \mathrm{m}^{2}\right)\end{array}$ & $\begin{array}{c}\text { Rigidez } \\
\text { Lhomargy } \\
(\mathrm{N} . \mathrm{mm})\end{array}$ & $\begin{array}{c}\text { Módulo de } \\
\text { Elasticidade } \\
\left(\mathrm{N} / \mathrm{mm}^{2}\right)\end{array}$ \\
\hline \multirow{3}{*}{12 horas } & 01 & 0,595 & 439 & 27,8 & 1583 \\
\hline & 02 & 0,595 & 439 & 27,8 & 1583 \\
\hline & 01 & 0,570 & 429 & 27,1 & 1757 \\
\hline \multirow{3}{*}{48 horas } & 02 & 0,570 & 429 & 25,7 & 1668 \\
\hline & 01 & 0,580 & 429 & 27,1 & 1668 \\
\hline \multirow{3}{*}{72 horas } & 02 & 0,570 & 430 & 25,8 & 1673 \\
\hline & 01 & 0,580 & 435 & 29,0 & 1787 \\
\hline \multirow{3}{*}{200 horas } & 01 & 0,580 & 432 & 28,8 & 1773 \\
\cline { 2 - 6 } & 02 & 0,580 & 430 & 27,2 & 1675 \\
\cline { 2 - 6 } & 01 & 0,580 & 431 & 27,3 & 1676 \\
\hline & 02 & 0,585 & 441 & 31,0 & 1858 \\
\hline
\end{tabular}

Os resultados encontrados de tensão de ruptura, alongamento na ruptura e módulo de elasticidade para cada amostra retirada nos periodos pré-estabelecidos estão apresentados nas Tabelas 5.22 e 5.23 .

Tabela 5.22 - Resultados do ensaio de tração - Amostra envelhecida na luz ultravioleta - Suco

\begin{tabular}{c|c|c|c|c}
\hline $\begin{array}{c}\text { Tempo de } \\
\text { exposição }\end{array}$ & $\mathrm{cp}$ & $\begin{array}{c}\text { Alongamento } \\
\text { na ruptura } \\
(\%)\end{array}$ & $\begin{array}{c}\text { Tensão de } \\
\text { ruptura } \\
(\mathrm{Mpa}\end{array}$ & $\begin{array}{c}\text { Módulo de } \\
\text { Elasticidade } \\
(\mathrm{MPa})\end{array}$ \\
\hline \multirow{3}{*}{12 horas } & 01 & 9,0 & 18,7 & 541 \\
\cline { 2 - 5 } 24 horas & 02 & 8,4 & 18,5 & 607 \\
\cline { 2 - 5 } & 01 & 7,3 & 19,1 & 665 \\
\hline \multirow{3}{*}{48 horas } & 02 & 7,4 & 19,2 & 601 \\
\cline { 2 - 5 } 72 horas & 01 & 8,3 & 19,2 & 643 \\
\hline \multirow{3}{*}{110 horas } & 01 & 7,6 & 19,2 & 658 \\
\cline { 2 - 5 } & 02 & 7,5 & 19,1 & 649 \\
\hline \multirow{3}{*}{200 horas } & 01 & 7,5 & 18,7 & 622 \\
\hline & 01 & 7,6 & 18,2 & 664 \\
\hline
\end{tabular}


Tabela 5.23 - Resultados do ensaio de tração - Amostra envelhecida na luz ultravioleta - Leite

\begin{tabular}{l|c|c|c|c}
\hline $\begin{array}{c}\text { Tempo de } \\
\text { exposição }\end{array}$ & $\mathrm{cp}$ & $\begin{array}{c}\text { Alongamento } \\
\text { na ruptura } \\
(\%)\end{array}$ & $\begin{array}{c}\text { Tensão de } \\
\text { ruptura } \\
(\mathrm{MPa})\end{array}$ & $\begin{array}{c}\text { Módulo de } \\
\text { Elasticidade } \\
(\mathrm{MPa})\end{array}$ \\
\hline \multirow{3}{*}{12 horas } & 01 & 4,2 & 30,8 & 1147 \\
\cline { 2 - 5 } 24 horas & 02 & 4,0 & 27,9 & - \\
\cline { 2 - 5 } & 02 & 4,1 & 29,3 & 1079 \\
\hline \multirow{3}{*}{48 horas } & 01 & 4,4 & 28,7 & 963 \\
\cline { 2 - 5 } 72 horas & 02 & 4,0 & 30,0 & 1076 \\
\hline \multirow{3}{*}{110 horas } & 01 & 4,0 & 29,2 & 1059 \\
\cline { 2 - 5 } & 02 & 4,5 & 31,2 & 1037 \\
\hline \multirow{3}{*}{200 horas } & 01 & 4,1 & 29,2 & 1061 \\
\cline { 2 - 5 } & 01 & 3,9 & 26,6 & 1002 \\
\cline { 2 - 5 } & 02 & 4,2 & 29,0 & 972 \\
\hline & 04 & 3,7 & 22,7 & 910 \\
\hline
\end{tabular}

As camadas externas das amostras foram submetidas a análise da estrutura química por espectrofotometria no infravermelho de acordo com a metodologia descrita no item $i$ em 4.3.1 do capítulo 4. As camadas internas não foram analisadas porque não foram expostas à luz ultravioleta.

As Figuras 5.10 e 5.11 apresentam os espectros dessas amostras após 200 horas de exposição à luz ultravioleta. Observa-se no espectro da embalagem de suco o surgimento de uma banda em $1700 \mathrm{~cm}^{-1}$, que pode representar um grupo carbonila devido a oxidação do polietileno.

O espectro da camada externa da embalagem de leite da Figura 5.11 não mostra alteração se comparado ao espectro desta mesma camada sem envelhecimento (Figura 5.2 do item 5.1.8 deste capítulo). 


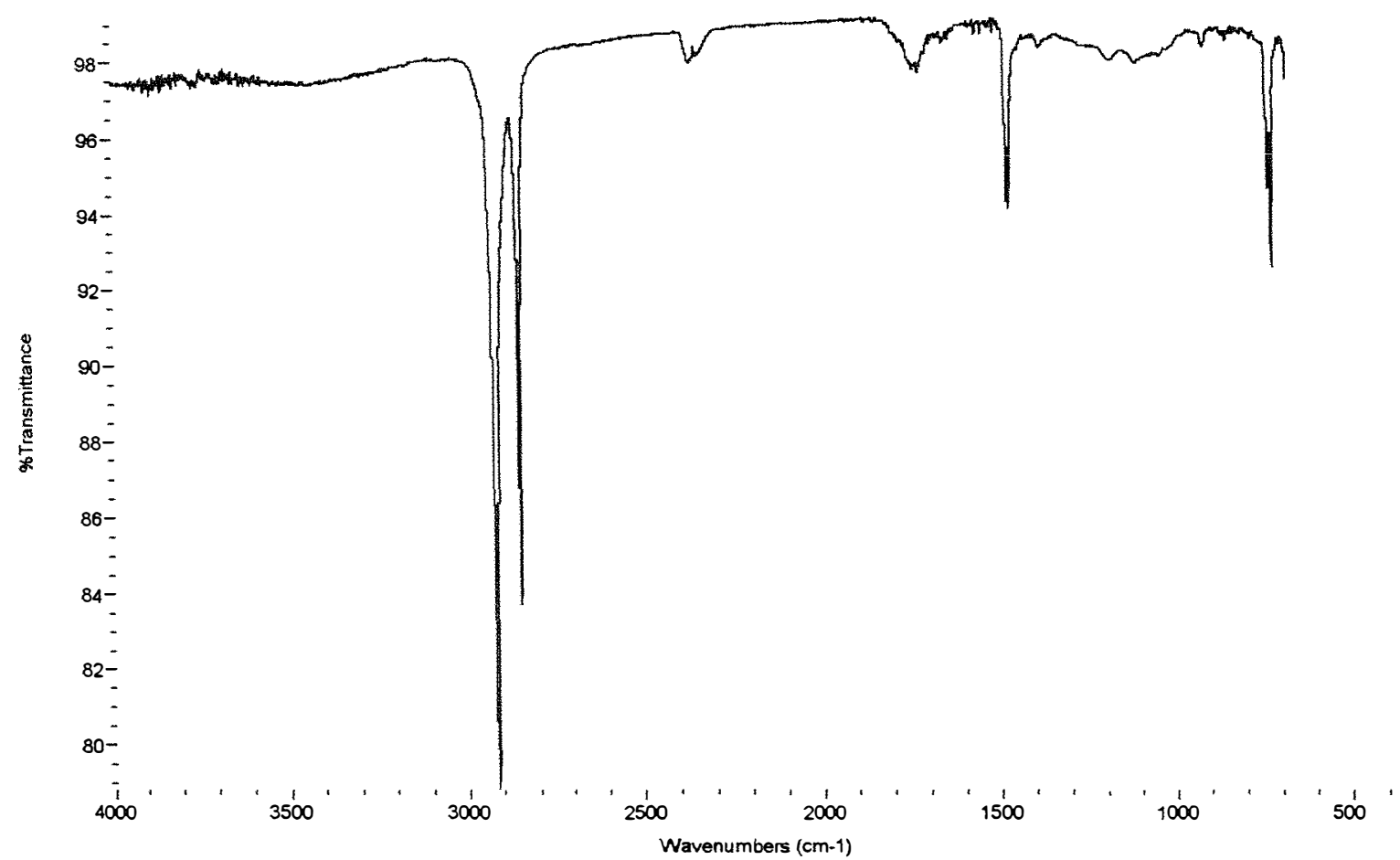

Figura 5.10 - Camada externa da amostra de suco após 200h de exposição em u.v. - polietileno oxidado

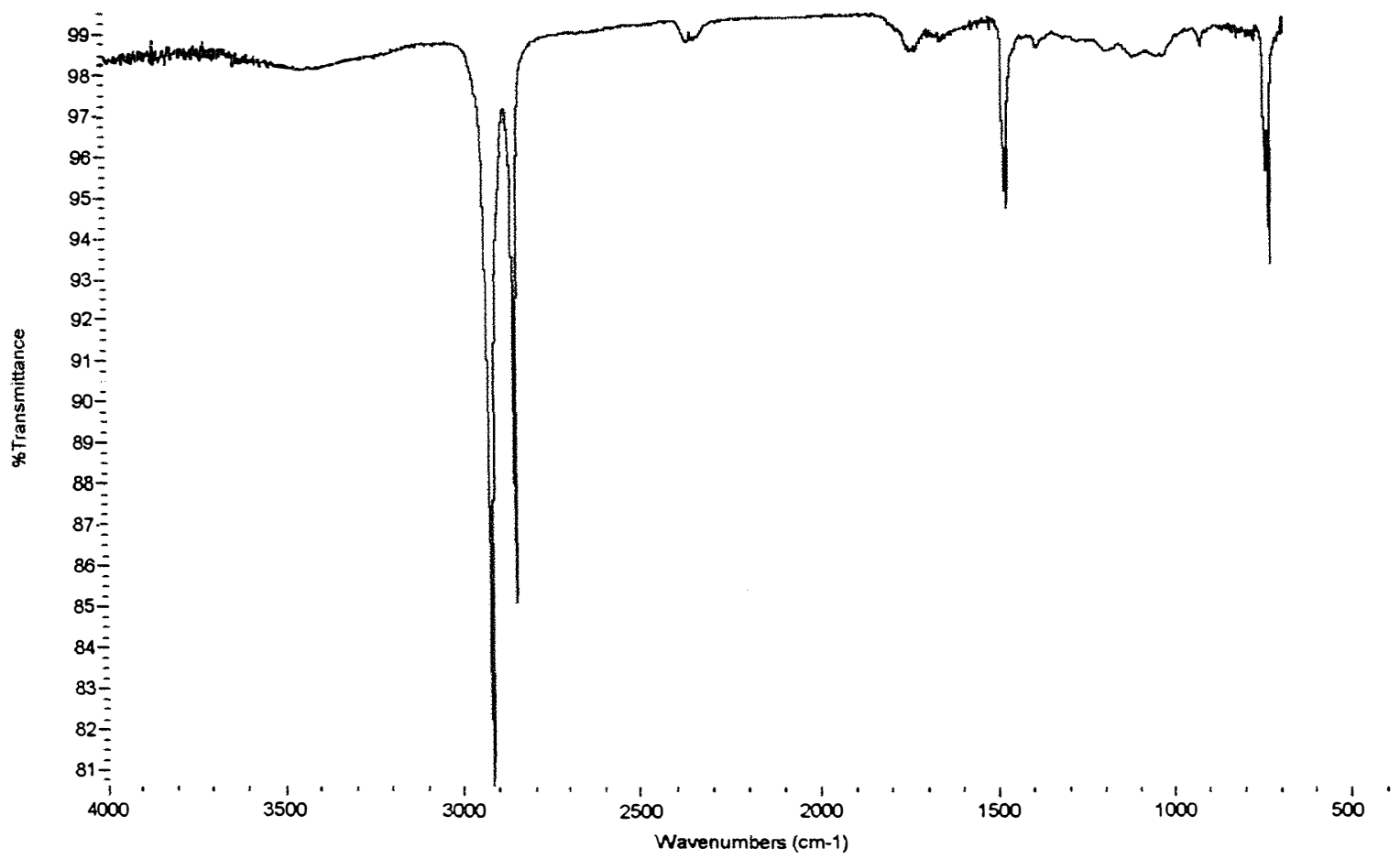

Figura 5.11 -Camada externa da amostra de leite após 200h de exposição em u.v. - polietileno 


\subsubsection{Degradabilidade por exposição às intempéries}

As amostras submetidas ao intemperismo natural, conforme o método descrito no item $d$ do sub-ítem 4.3.2 do capítulo 4, apresentaram aspecto visual alterado em relação a original, principalmente a amostra de leite (Fotos 10 e 11).

A amostra de suco com seis meses de envelhecimento colocada no mesmo período do ano que as demais foi substituída por outra, porque a originalmente colocada foi arrancada do painel de envelhecimento pelas chuvas e ventos e extraviou-se.

As amostras multicamadas de suco e leite após a exposição do intemperismo natural foram submetidas aos ensaios de determinação da gramatura para analisar a perda de massa e aos ensaios de determinação de rigidez Lhomargy e de determinação da resistência à tração para avaliar a perda de resistência mecânica. Os métodos de ensaio utilizados foram os descritos nos itens $g, b$ e $f$ em 4.3.1 do capítulo 4 .

Os resultados de gramatura para ambas as amostras estão apresentados na Tabela 5.24.

Tabela 5.24 - Gramatura das amostras após intemperismo natural $\left(\mathrm{g} / \mathrm{m}^{2}\right)$.

\begin{tabular}{c|c|c}
\hline $\begin{array}{c}\text { Tempo } \\
\text { (meses) }\end{array}$ & Amostra Suco & Amostra Leite \\
\hline 1 & 429 & 377 \\
\hline 2 & 431 & 385 \\
\hline 3 & 425 & 383 \\
\hline 4 & 422 & 371 \\
\hline 5 & 423 & 289 \\
\hline 6 & 422 & 280 \\
\hline
\end{tabular}




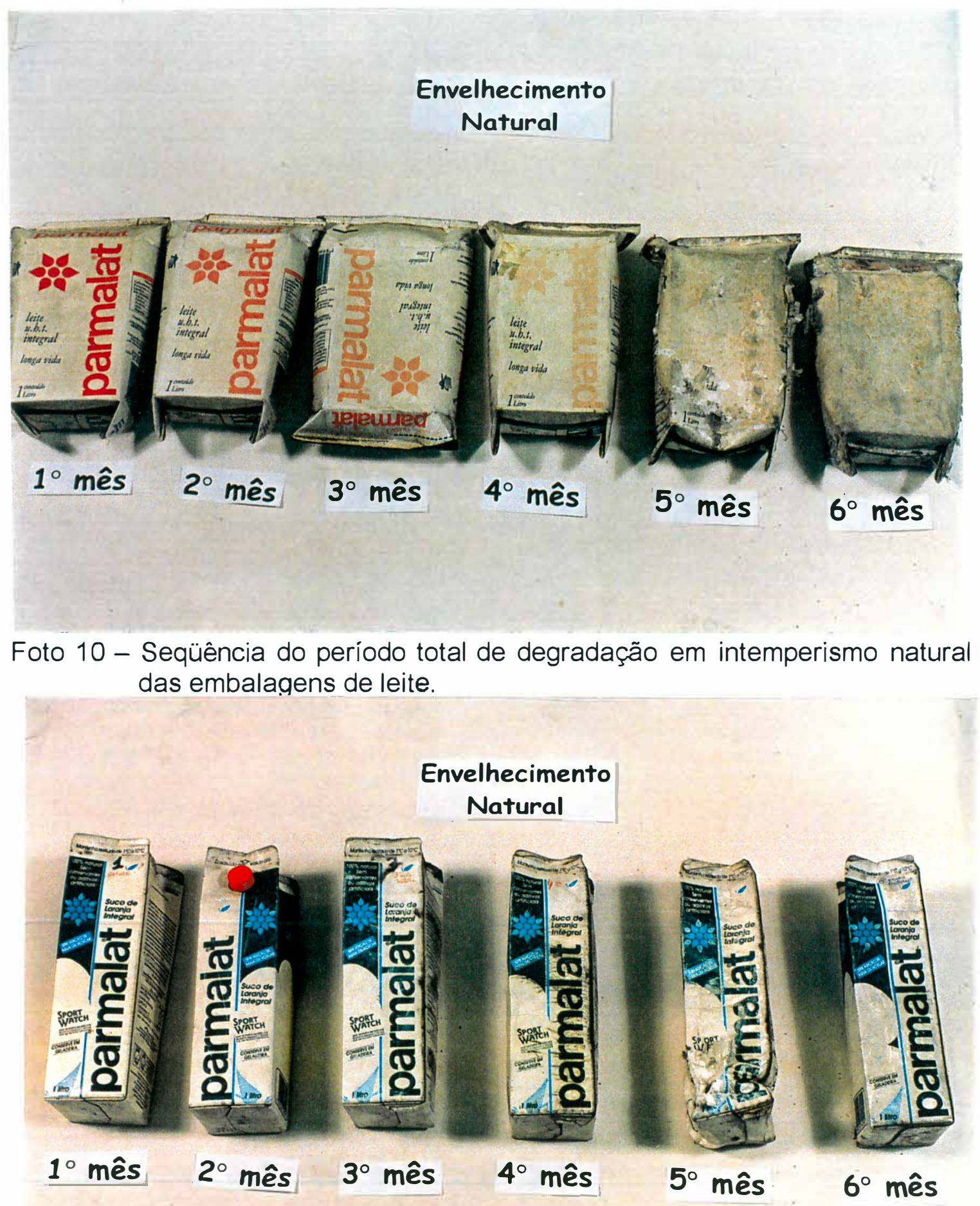

Foto 11 - Seqüência do período total de degradação em intemperismo natural das embalagens de suco. 
Os resultados encontrados de rigidez Lhomargy para cada amostra retirada nos períodos pré-estabelecidos estão apresentados nas Tabelas 5.25 e 5.26 .

5.25 - Resultados do ensaio de rigidez Lhomargy - Amostra envelhecida no intemperismo natural - Leite

\begin{tabular}{|c|c|c|c|c|c|}
\hline $\begin{array}{l}\text { Tempo de } \\
\text { exposição }\end{array}$ & $c p$ & $\begin{array}{l}\text { Espessura } \\
(\mathrm{mm})\end{array}$ & $\begin{array}{c}\text { Gramatura } \\
\left(\mathrm{g} / \mathrm{m}^{2}\right)\end{array}$ & $\begin{array}{l}\text { Rigidez } \\
\text { Lhomargy } \\
\text { (N.mm) }\end{array}$ & $\begin{array}{l}\text { Módulo de } \\
\text { Elasticidade } \\
\left(\mathrm{N} / \mathrm{mm}^{2}\right)\end{array}$ \\
\hline \multirow{3}{*}{1 mês } & 01 & 0,530 & 387 & 53,1 & 4276 \\
\hline & 02 & 0,530 & 387 & 53,1 & 4277 \\
\hline & 03 & 0,530 & 382 & 50,2 & 4044 \\
\hline \multirow{3}{*}{2 meses } & 01 & 0,530 & 385 & 48,4 & 3898 \\
\hline & 02 & 0,530 & 385 & 48,3 & 3892 \\
\hline & 03 & 0,530 & 385 & 48,3 & 3893 \\
\hline \multirow{3}{*}{3 meses } & 01 & 0,550 & 390 & 35,2 & 2542 \\
\hline & 02 & 0,540 & 384 & 48,2 & 3670 \\
\hline & 03 & 0,550 & 387 & 46,4 & 3348 \\
\hline \multirow{3}{*}{4 meses } & 01 & 0,545 & 379 & 49,7 & 3685 \\
\hline & 02 & 0,550 & 382 & 32,9 & 2372 \\
\hline & 03 & 0,545 & 377 & 45,3 & 3354 \\
\hline \multirow{3}{*}{5 meses } & 01 & 0,564 & 302 & 16,2 & 1084 \\
\hline & 02 & 0,535 & 295 & 12,6 & 989 \\
\hline & 03 & 0,572 & 304 & 10,2 & 654 \\
\hline \multirow{3}{*}{6 meses } & 01 & 0,528 & 288 & 9,7 & 789 \\
\hline & 02 & 0,576 & 287 & 11,6 & 726 \\
\hline & 03 & 0,504 & 282 & 8,9 & 832 \\
\hline
\end{tabular}

Tabela 5.26 - Resultados do ensaio de rigidez Lhomargy - Amostra envelhecida no intemperismo natural - Suco

\begin{tabular}{c|c|c|c|c|c}
\hline $\begin{array}{c}\text { Tempo de } \\
\text { exposição }\end{array}$ & $\mathrm{cP}$ & $\begin{array}{c}\text { Espessura } \\
(\mathrm{mm})\end{array}$ & $\begin{array}{c}\text { Gramatura } \\
\left(\mathrm{g} / \mathrm{m}^{2}\right)\end{array}$ & $\begin{array}{c}\text { Rigidez } \\
\text { Lhomargy } \\
(\mathrm{N} . \mathrm{mm})\end{array}$ & $\begin{array}{c}\text { Módulo de } \\
\text { Elasticidade } \\
\left(\mathrm{N} / \mathrm{mm}^{2}\right)\end{array}$ \\
\hline & 01 & 0,610 & 441 & 31,0 & 1641 \\
\cline { 2 - 6 } 1 mês & 02 & 0,620 & 436 & 30,6 & 1542 \\
\hline & 01 & 0,620 & 431 & 37,1 & 1869 \\
\hline \multirow{3}{*}{ meses } & 02 & 0,610 & 442 & 38,0 & 2010 \\
\hline & 01 & 0,600 & 430 & 25,8 & 1433 \\
\hline & 02 & 0,610 & 431 & 27,3 & 1442 \\
\hline & 01 & 0,660 & 427 & 18,3 & 762 \\
\hline & 02 & 0,690 & 423 & 19,2 & 701 \\
\hline & 01 & 0,681 & 389 & 8,8 & 334 \\
\hline & 02 & 0,692 & 431 & 4,6 & 166 \\
\hline & 01 & 0,620 & 429 & 25,7 & 1296 \\
\hline
\end{tabular}


Os resultados encontrados de tensão de ruptura, alongamento na ruptura e módulo de elasticidade para cada amostra retirada nos períodos pré-estabelecidos estão apresentados nas Tabelas 5.27 e 5.28.

Tabela 5.27 - Resultados do ensaio de tração - Amostra envelhecida no intemperismo natural - Suco

\begin{tabular}{|c|c|c|c|c|}
\hline $\begin{array}{l}\text { Tempo de } \\
\text { exposição }\end{array}$ & $c p$ & $\begin{array}{c}\text { Alongamento } \\
\text { na nuptura } \\
(\%)\end{array}$ & $\begin{array}{l}\text { Tensão de } \\
\text { ruptura } \\
\text { (MPa }\end{array}$ & $\begin{array}{l}\text { Módulo de } \\
\text { Elasticidade } \\
\text { (MPa) }\end{array}$ \\
\hline \multirow[b]{2}{*}{1 mês } & 01 & 7,7 & 13,4 & 423 \\
\hline & 02 & 8,3 & 13,3 & 434 \\
\hline \multirow[b]{2}{*}{2 meses } & 01 & 8,2 & 12,8 & 430 \\
\hline & 02 & 6,7 & 12,3 & 425 \\
\hline \multirow[b]{2}{*}{3 meses } & 01 & 4,4 & 10,0 & 441 \\
\hline & 02 & 4,5 & 10,2 & 459 \\
\hline \multirow[b]{2}{*}{4 meses } & 01 & 4,1 & 5,4 & 216 \\
\hline & 02 & 3,2 & 3,2 & 195 \\
\hline \multirow[b]{2}{*}{5 meses } & 01 & 4,6 & 4,3 & 222 \\
\hline & 02 & 4,7 & 3,2 & 176 \\
\hline \multirow[b]{2}{*}{6 meses } & 01 & 4,7 & 9,4 & 426 \\
\hline & 02 & 3,8 & 7,7 & 358 \\
\hline
\end{tabular}

Tabela 5.28 - Resultados do ensaio de tração - Amostra envelhecida no intemperismo natural - Leite

\begin{tabular}{|c|c|c|c|c|}
\hline $\begin{array}{l}\text { Tempo de } \\
\text { exposição }\end{array}$ & $c p$ & $\begin{array}{c}\text { Alongamento } \\
\text { na ruptura } \\
(\%)\end{array}$ & $\begin{array}{l}\text { Tensão de } \\
\text { ruptura } \\
\text { (MPa) }\end{array}$ & $\begin{array}{l}\text { Módulo de } \\
\text { Elasticidacie } \\
\text { (MPa) }\end{array}$ \\
\hline \multirow{3}{*}{1 mês } & 01 & 4,1 & 25,1 & 785 \\
\hline & 02 & 4,6 & 27,5 & 833 \\
\hline & 03 & 4,0 & 24,8 & 867 \\
\hline \multirow{3}{*}{2 meses } & 01 & 3,2 & 18,1 & 773 \\
\hline & 02 & 3,6 & 19,8 & 759 \\
\hline & 03 & 3,9 & 22,8 & 829 \\
\hline \multirow{3}{*}{3 meses } & 01 & 3,0 & 15,9 & 739 \\
\hline & 02 & 3,4 & 17,4 & 727 \\
\hline & 03 & 3,4 & 17,7 & 649 \\
\hline \multirow{3}{*}{4 meses } & 01 & 3,5 & 14,5 & 672 \\
\hline & 02 & 3,2 & 13,6 & 642 \\
\hline & 03 & 3,4 & 14,9 & 672 \\
\hline \multirow{3}{*}{5 meses } & 01 & 3,6 & 9,8 & 371 \\
\hline & 02 & 4,4 & 12,0 & 382 \\
\hline & 03 & 4,5 & 12,4 & 399 \\
\hline \multirow{3}{*}{6 meses } & 01 & 4,7 & 9,7 & 326 \\
\hline & 02 & 5,3 & 8,6 & 226 \\
\hline & 03 & 5,1 & 10,0 & 225 \\
\hline
\end{tabular}


As camadas externas das amostras foram submetidas a análise da estrutura química por espectrofotometria no infravermelho de acordo com a metodologia descrita no item $i$ em 4.3.1 do capítulo 4. As camadas internas não foram analisadas porque não foram expostas às intempéries.

As Figuras 5.12 e 5.13 apresentam os espectros dessas amostras após a exposição às intempéries. Observa-se nestes espectros 0 surgimento de bandas nas regiões de $1700 \mathrm{~cm}^{-1}$ e $1000 \mathrm{~cm}^{-1}$ que não pertencem ao espectro de um polietileno, conforme visto na Figura 5.1.

A banda em $1000 \mathrm{~cm}^{-1}$ pode ser caracterizada como um grupo vinil com isomeria trans e a banda em $1700 \mathrm{~cm}^{-1}$ como um grupo carbonila (Sadtler, 1980).

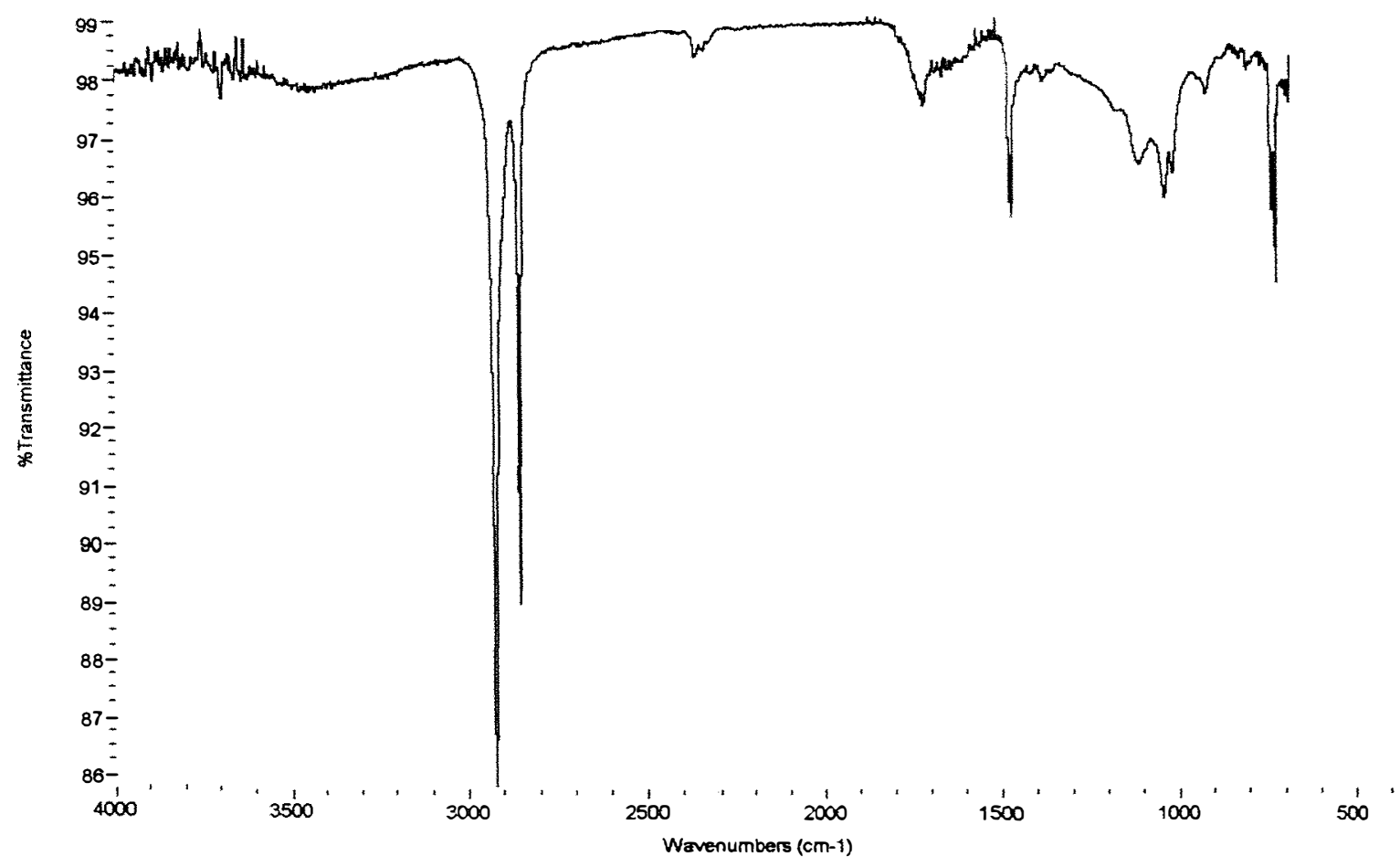

Figura 5.12 - Camada externa da amostra de leite após seis meses de exposição às intempéries 


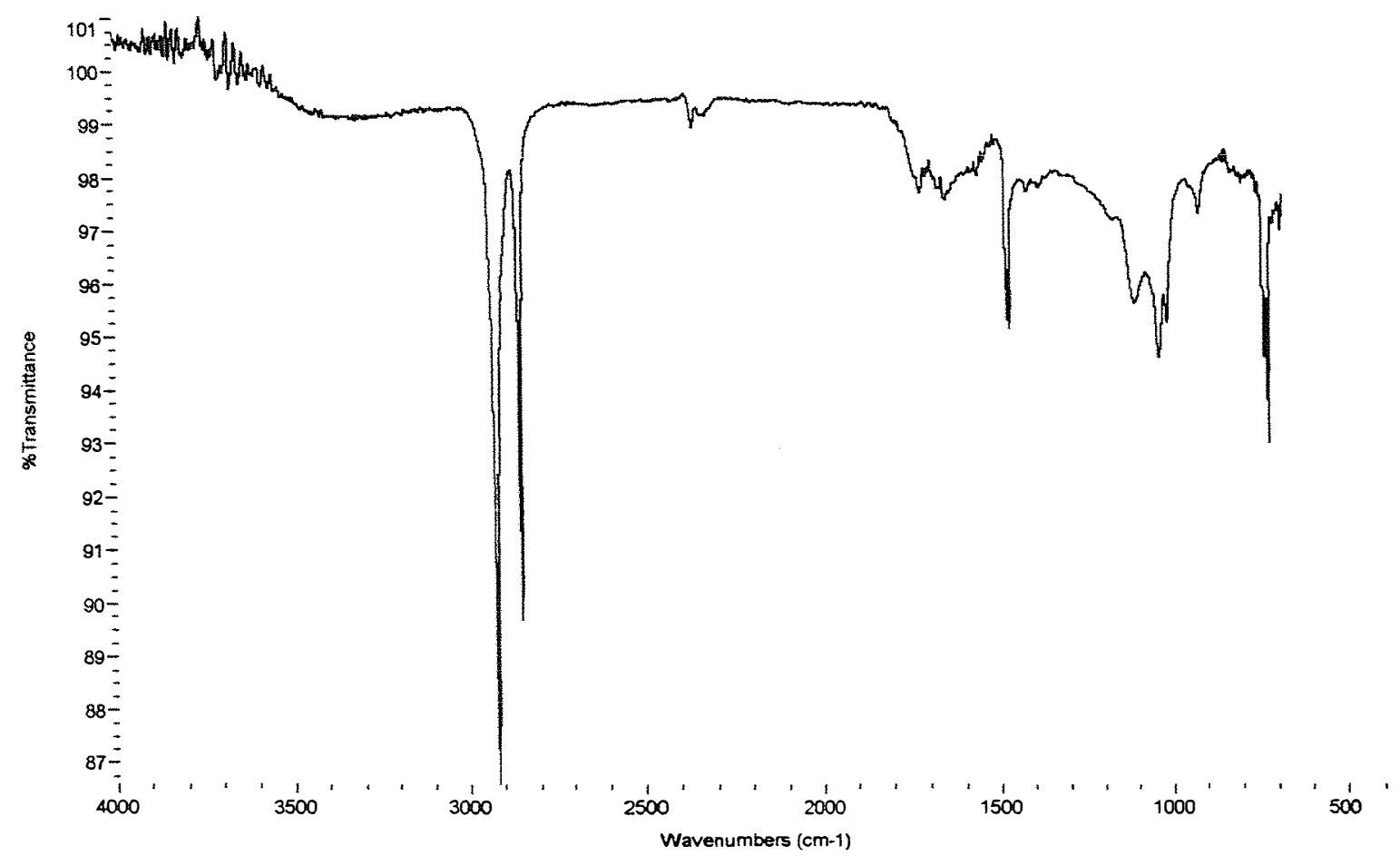

Figura 5.13 - Camada externa da amostra de suco após 5 meses de exposição às intempéries.

\subsubsection{Degradabilidade por ação do calor}

As amostras submetidas a ação do calor, conforme o método descrito no item $c$ do sub-ítem 4.3.2 do capítulo 4, apresentaram aspecto visual com pouca alteração relação a original, somente na amostra de leite ocorreu a delaminação da camada interna (Fotos 12 e 13).

As amostras multicamadas de suco e leite após o envelhecimento na estufa foram submetidas aos ensaios de determinação da gramatura para analisar a perda de massa e aos ensaios de determinação de rigidez Lhomargy e de determinação da resistência à tração para avaliar a perda de resistência mecânica. Os métodos de ensaio utilizados foram os descritos nos itens $g, b$ e $f$ em 4.3 .1 do capítulo 4. 


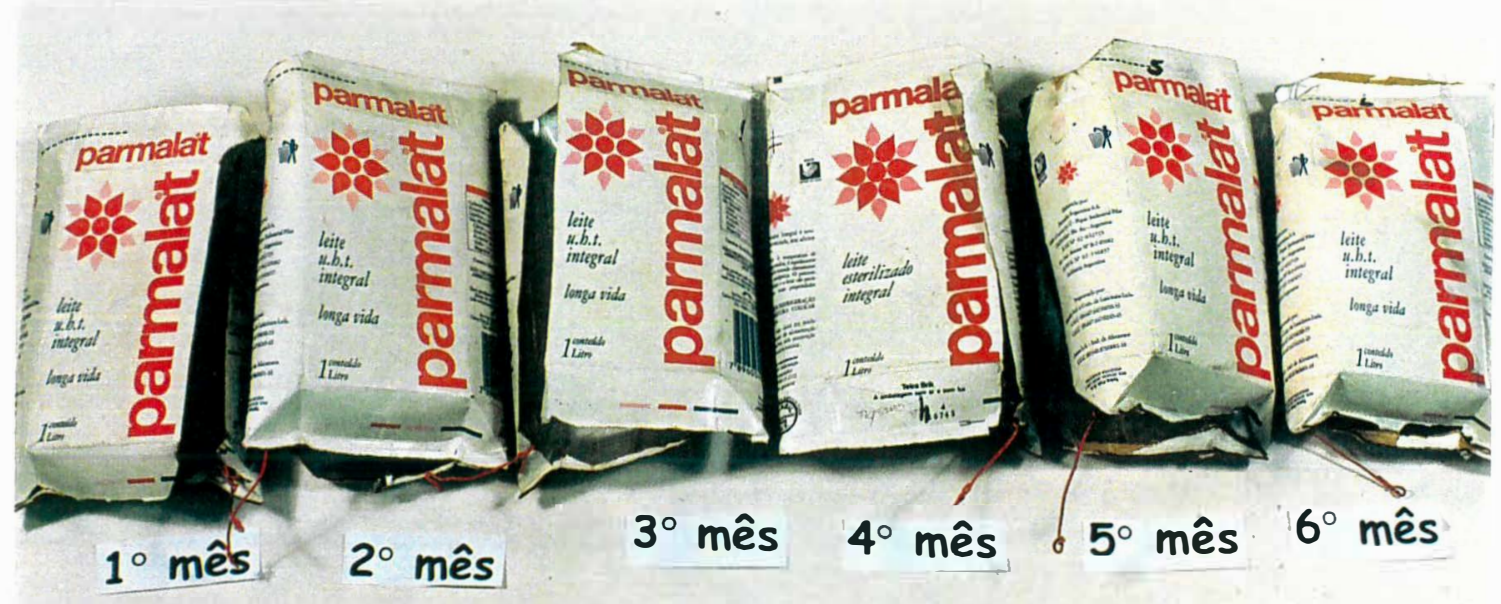

Foto 12 - Seqüência do período total de degradação por ação do calor das embalagens de leite.

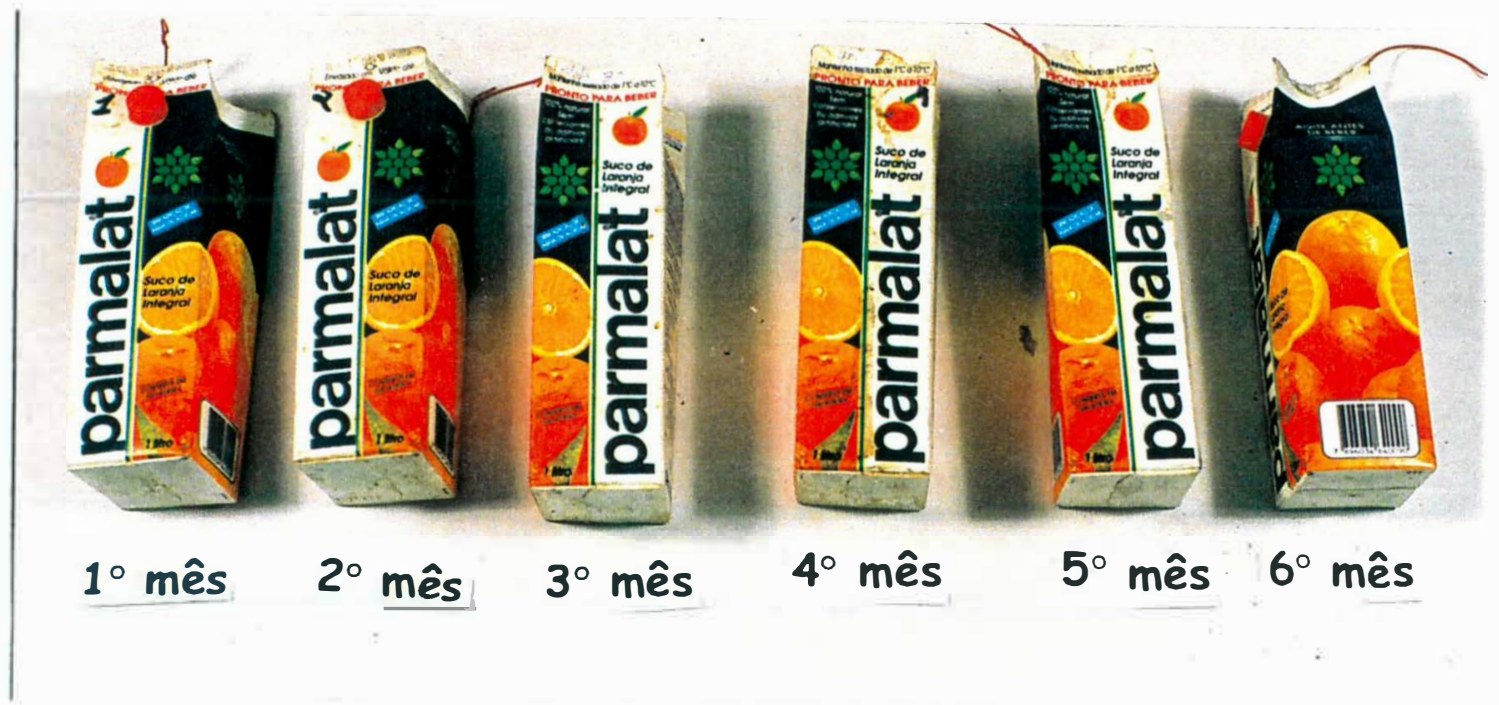

Foto 13 - Seqüência do período total de degradação por ação do calor das embalagens de suco. 
Os resultados de gramatura para ambas as amostras estão apresentados na Tabela 5.29.

Tabela 5.29 - Gramatura das amostras após envelhecimento na estufa $\left(\mathrm{g} / \mathrm{m}^{2}\right)$.

\begin{tabular}{c|c|c}
\hline $\begin{array}{c}\text { Tempo } \\
\text { (meses) }\end{array}$ & Amostra Suco & Amostra Leite \\
\hline 1 & 434 & 363 \\
\hline 2 & 433 & 373 \\
\hline 3 & 430 & 368 \\
\hline 4 & 431 & 358 \\
\hline 5 & 430 & 386 \\
\hline 6 & 436 & 375 \\
\hline \multicolumn{2}{|c}{}
\end{tabular}

Os resultados encontrados de rigidez Lhomargy para cada amostra retirada nos períodos pré-estabelecidos estão apresentados nas Tabelas 5.30 e 5.31 .

Tabela 5.30 - Resultados do ensaio de rigidez Lhomargy - Amostra envelhecida na estufa - Suco

\begin{tabular}{l|c|c|c|c|c}
\hline $\begin{array}{l}\text { Tempo de } \\
\text { exposição }\end{array}$ & $c p$ & $\begin{array}{c}\text { Espessura } \\
(\mathrm{mm})\end{array}$ & $\begin{array}{c}\text { Gramatura } \\
\left(\mathrm{g} / \mathrm{m}^{2}\right)\end{array}$ & $\begin{array}{c}\text { Rigidez } \\
\text { Lhomargy } \\
(\mathrm{N} . \mathrm{mm})\end{array}$ & $\begin{array}{c}\text { Módulo de } \\
\text { Elasticidade } \\
\left(\mathrm{N} / \mathrm{mm}^{2}\right)\end{array}$ \\
\hline \multirow{3}{*}{1 mês } & 01 & 0,590 & 439 & 26,3 & 1538 \\
\cline { 2 - 6 } & 02 & 0,600 & 445 & 29,1 & 1615 \\
\hline \multirow{3}{*}{2 meses } & 03 & 0,600 & 438 & 29,2 & 1623 \\
\cline { 2 - 7 } & 01 & 0,595 & 438 & 29,2 & 1664 \\
\hline \multirow{3}{*}{3 meses } & 02 & 0,610 & 435 & 29,0 & 1534 \\
\hline \multirow{3}{*}{4 meses } & 01 & 0,610 & 442 & 26,5 & 1401 \\
\cline { 2 - 7 } & 02 & 0,595 & 437 & 29,2 & 1662 \\
\hline \multirow{3}{*}{5 meses } & 03 & 0,595 & 433 & 30,5 & 1736 \\
\cline { 2 - 7 } & 02 & 0,695 & 436 & 29,1 & 1657 \\
\cline { 2 - 7 } & 03 & 0,595 & 437 & 29,1 & 1619 \\
\hline \multirow{3}{*}{6 meses } & 02 & 0,600 & 436 & 30,7 & 1704 \\
\cline { 2 - 7 } & 03 & 0,590 & 438 & 29,2 & 1707 \\
\cline { 2 - 7 } & 02 & 0,590 & 437 & 27,7 & 1617 \\
\hline & 03 & 0,590 & 436 & 30,7 & 1792 \\
\hline
\end{tabular}


Tabela 5.31 - Resultados do ensaio de rigidez Lhomargy - Amostra envelhecida na estufa - Leite

\begin{tabular}{|c|c|c|c|c|c|}
\hline $\begin{array}{l}\text { Tempo de } \\
\text { exposição }\end{array}$ & $c p$ & $\begin{array}{l}\text { Espessura } \\
(\mathrm{mm})\end{array}$ & $\begin{array}{c}\text { Gramatura } \\
\left(\mathrm{g} / \mathrm{m}^{2}\right)\end{array}$ & $\begin{array}{l}\text { Rigidez } \\
\text { Lhomargy } \\
\text { (N.mm) }\end{array}$ & $\begin{array}{l}\text { Módulo de } \\
\text { Elasticidade } \\
\left(\mathrm{N} / \mathrm{mm}^{2}\right)\end{array}$ \\
\hline \multirow{3}{*}{1 mês } & 01 & 0,540 & 370 & 60,2 & 4587 \\
\hline & 02 & 0,530 & 365 & 52,3 & 4214 \\
\hline & 03 & 0,530 & 365 & 50,1 & 4040 \\
\hline \multirow{3}{*}{2 meses } & 01 & 0,515 & 379 & 45,5 & 3994 \\
\hline & 02 & 0,520 & 379 & 47,6 & 4060 \\
\hline & 03 & 0,520 & 385 & 50,5 & 4307 \\
\hline \multirow{3}{*}{3 meses } & 01 & 0,490 & 335 & 59,3 & 6045 \\
\hline & 02 & 0,490 & 334 & $61,5 \mid$ & 6277 \\
\hline & 03 & 0,490 & 335 & 52,3 & 5336 \\
\hline \multirow{3}{*}{4 meses } & 01 & 0,490 & 348 & 45,7 & 4658 \\
\hline & 02 & 0,495 & 347 & 49,8 & 4925 \\
\hline & 03 & 0,490 & 341 & 48,9 & 4984 \\
\hline \multirow{3}{*}{5 meses } & 01 & 0,465 & 337 & 46,2 & 5519 \\
\hline & 02 & 0,465 & 338 & 46,4 & 5537 \\
\hline & 03 & 0,470 & 334 & 45,8 & 5299 \\
\hline \multirow{3}{*}{6 meses } & 01 & 0,515 & 376 & 45,1 & 3962 \\
\hline & 02 & 0,510 & 384 & 57,4 & 5197 \\
\hline & 03 & 0,515 & 381 & 52,3 & 4592 \\
\hline
\end{tabular}

Os resultados encontrados de tensão de ruptura, alongamento na ruptura e módulo de elasticidade para cada amostra retirada nos períodos pré-estabelecidos estão apresentados nas Tabelas 5.32 e 5.33. 
Tabela 5.32 - Resultados do ensaio de traçāo - Amostra envelhecida na estufa - Suco

\begin{tabular}{|c|c|c|c|c|}
\hline $\begin{array}{l}\text { Tempo de } \\
\text { exposição }\end{array}$ & $c p$ & $\begin{array}{c}\text { Alongamento } \\
\text { na nuptura } \\
(\%)\end{array}$ & $\begin{array}{l}\text { Tensão de } \\
\text { ruptura } \\
\text { (MPa }\end{array}$ & $\begin{array}{l}\text { Módulo de } \\
\text { Elasticidade } \\
\text { (MPa) }\end{array}$ \\
\hline \multirow{3}{*}{1 mês } & 01 & 8,3 & 18,0 & 505 \\
\hline & 02 & 7,9 & 18,0 & 576 \\
\hline & 03 & 8,1 & 18,1 & 545 \\
\hline \multirow{3}{*}{2 meses } & 01 & 8,3 & 18,5 & 603 \\
\hline & 02 & 8,4 & 17,9 & 600 \\
\hline & 03 & 8,2 & 17,8 & 429 \\
\hline \multirow{3}{*}{3 meses } & 01 & 7,9 & 18,3 & 554 \\
\hline & 02 & 7,4 & 17,5 & 600 \\
\hline & 03 & 8,5 & 18,8 & 697 \\
\hline \multirow{3}{*}{4 meses } & 01 & 8,2 & 18,4 & 598 \\
\hline & 02 & 7,4 & 17,8 & 643 \\
\hline & 03 & 8,2 & 18,6 & 635 \\
\hline \multirow{3}{*}{5 meses } & 01 & 7,6 & 18,3 & 599 \\
\hline & 02 & 8,0 & 18,7 & 608 \\
\hline & 03 & 8,4 & 19,2 & 606 \\
\hline \multirow{3}{*}{6 meses } & 01 & 7,6 & 18,3 & 599 \\
\hline & 02 & 8,0 & 18,7 & 608 \\
\hline & 03 & 8,4 & 19,0 & 601 \\
\hline
\end{tabular}

Tabela 5.33 - Resultados do ensaio de tração - Amostra envelhecida na estufa - Leite

\begin{tabular}{|c|c|c|c|c|}
\hline $\begin{array}{l}\text { Tempo de } \\
\text { exposição }\end{array}$ & $c p$ & $\begin{array}{c}\text { Alongamento } \\
\text { na ruptura } \\
(\%)\end{array}$ & $\begin{array}{c}\text { Tensão de } \\
\text { ruptura } \\
\text { (MPa }\end{array}$ & $\begin{array}{l}\text { Módulo de } \\
\text { Elasticidade } \\
\text { (MPa) }\end{array}$ \\
\hline \multirow{3}{*}{1 mês } & 01 & 5,1 & 31,5 & 1046 \\
\hline & 02 & 4,5 & 32,0 & 1058 \\
\hline & 03 & 4,4 & 31,7 & 846 \\
\hline \multirow{3}{*}{2 meses } & 01 & 4,1 & 31,7 & 1168 \\
\hline & 02 & 3,7 & 29,7 & 1082 \\
\hline & 03 & 4,0 & 31,7 & 1147 \\
\hline \multirow{3}{*}{3 meses } & 01 & 4,1 & 35,8 & 1121 \\
\hline & 02 & 3,8 & 32,1 & 1201 \\
\hline & 03 & 3,4 & 30,9 & 1361 \\
\hline \multirow{3}{*}{4 meses } & 01 & 3,4 & 32,9 & - \\
\hline & 02 & 3,3 & 28,9 & 1110 \\
\hline & 03 & 3,5 & 31,5 & 1249 \\
\hline \multirow{3}{*}{5 meses } & 01 & 3,4 & 31,4 & 1266 \\
\hline & 02 & 3,8 & 37,1 & 1210 \\
\hline & 03 & 3,7 & 34,0 & 1058 \\
\hline \multirow{3}{*}{6 meses } & 01 & 3,8 & 30,2 & 1116 \\
\hline & 02 & 3,8 & 31,2 & 1103 \\
\hline & 03 & 3,3 & 27,9 & 1067 \\
\hline
\end{tabular}


As camadas externas e internas das amostras foram submetidas a análise da estrutura química por espectrofotometria no infravermelho de acordo com a metodologia descrita no item $i$ em 4.3.1 do capitulo 4.

As Figuras 5.14, 5.15 e 5.16 apresentam os espectros das camadas externas de ambas as amostras e da camada interna da embalagem de leite após seis meses de envelhecimento em estufa. Observa-se nestes espectros o surgimento de uma banda na região de $1700 \mathrm{~cm}^{-1}$ que não pertence ao espectro de um polietileno, conforme visto na Figura 5.1. Esta banda em $1700 \mathrm{~cm}^{-1}$ pode ser caracterizada como um grupo carbonila (Sadtler, 1980).

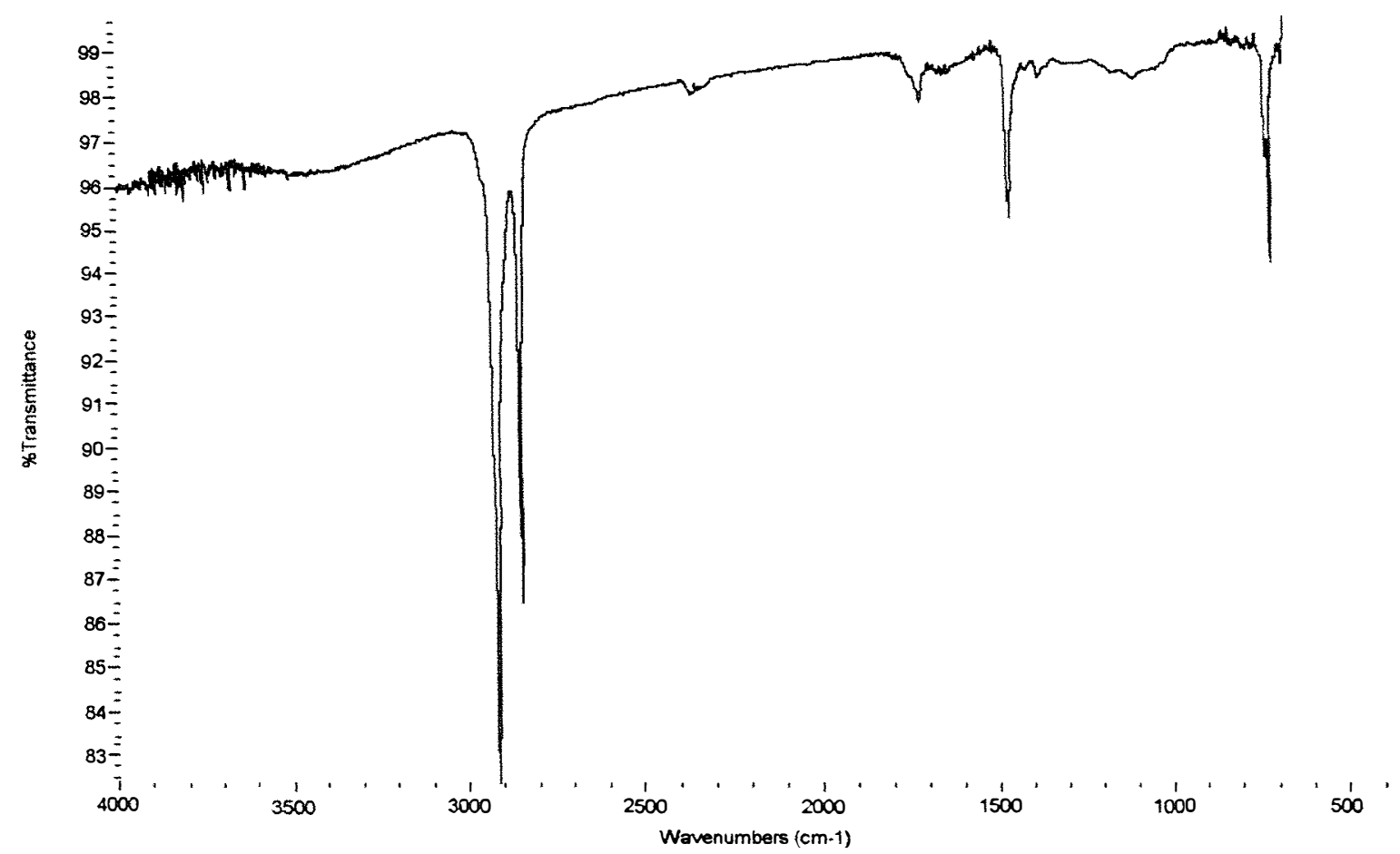

Figura 5.14 - Camada externa da amostra de leite após seis meses de envelhecimento na estufa - polietileno oxidado 


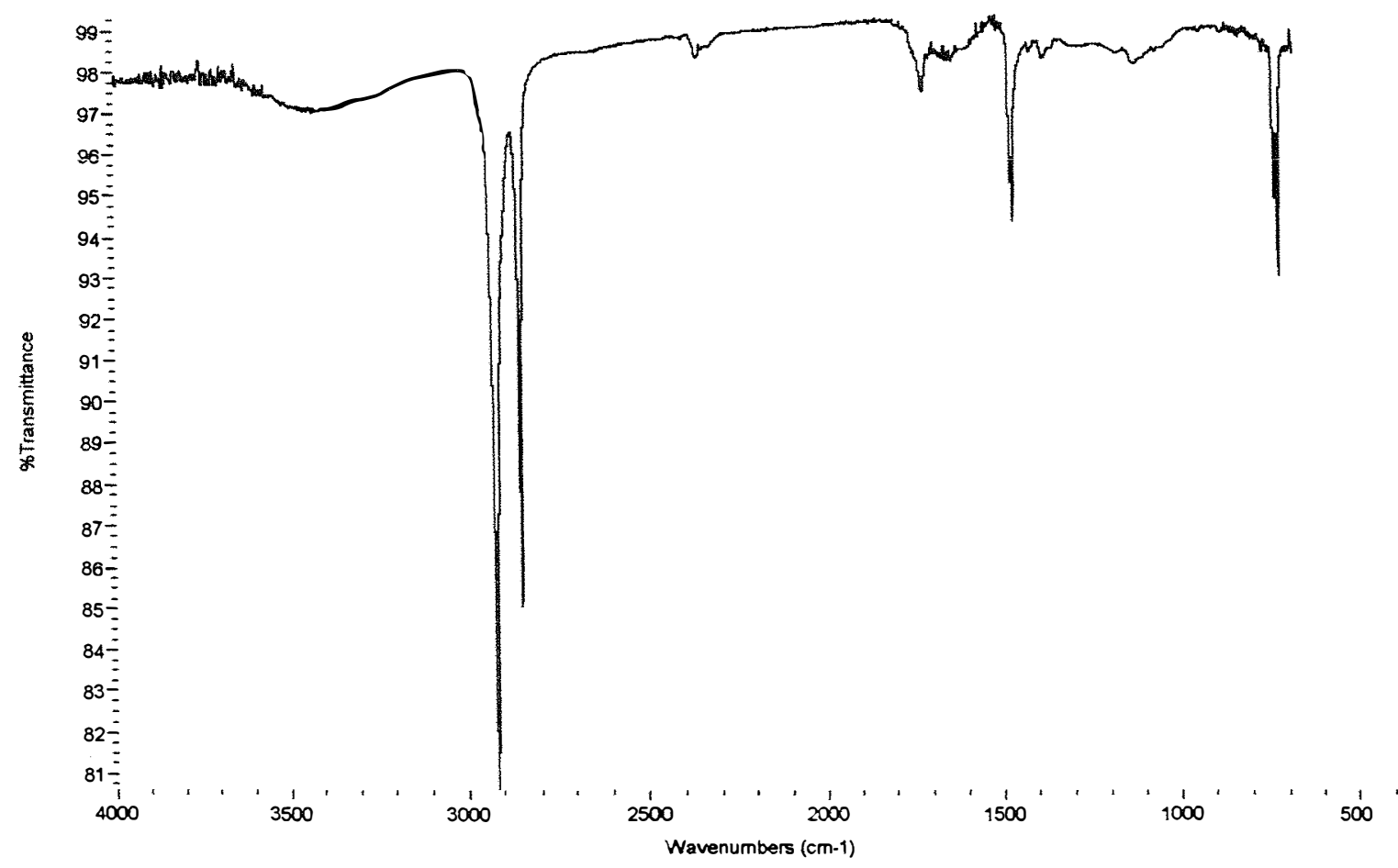

Figura 5.15 - Camada externa da amostra de suco após 6 meses de envelhecimento na estufa - polietileno oxidado

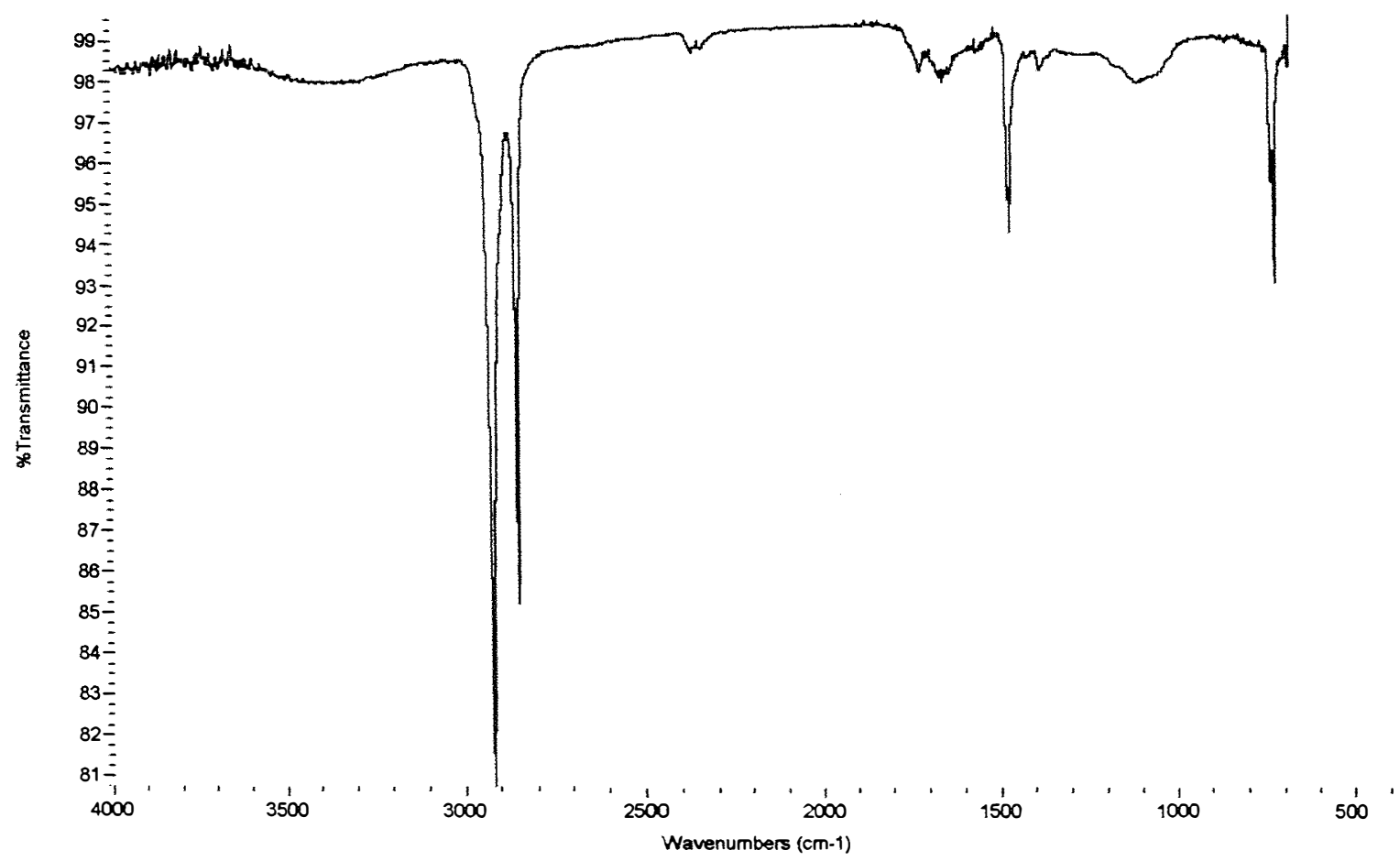

Figura 5.16 - Camada interna da amostra de leite após seis meses de envelhecimento na estufa - polietileno oxidado 
A Figura 5.17 apresenta o espectro da camada interna do suco após seis meses de envelhecimento em estufa. Observa-se neste espectro, além da banda em $1700 \mathrm{~cm}^{-1}$, uma banda em $1000 \mathrm{~cm}^{-1}$, que como dito anteriormente pode ser caracterizada por um grupo vinil com isomeria trans e uma banda em $3400 \mathrm{~cm}^{-1}$ característica de hidroxila $(-\mathrm{OH})$ que não estavam presentes no espectro original desta camada (ver Figura 5.5).

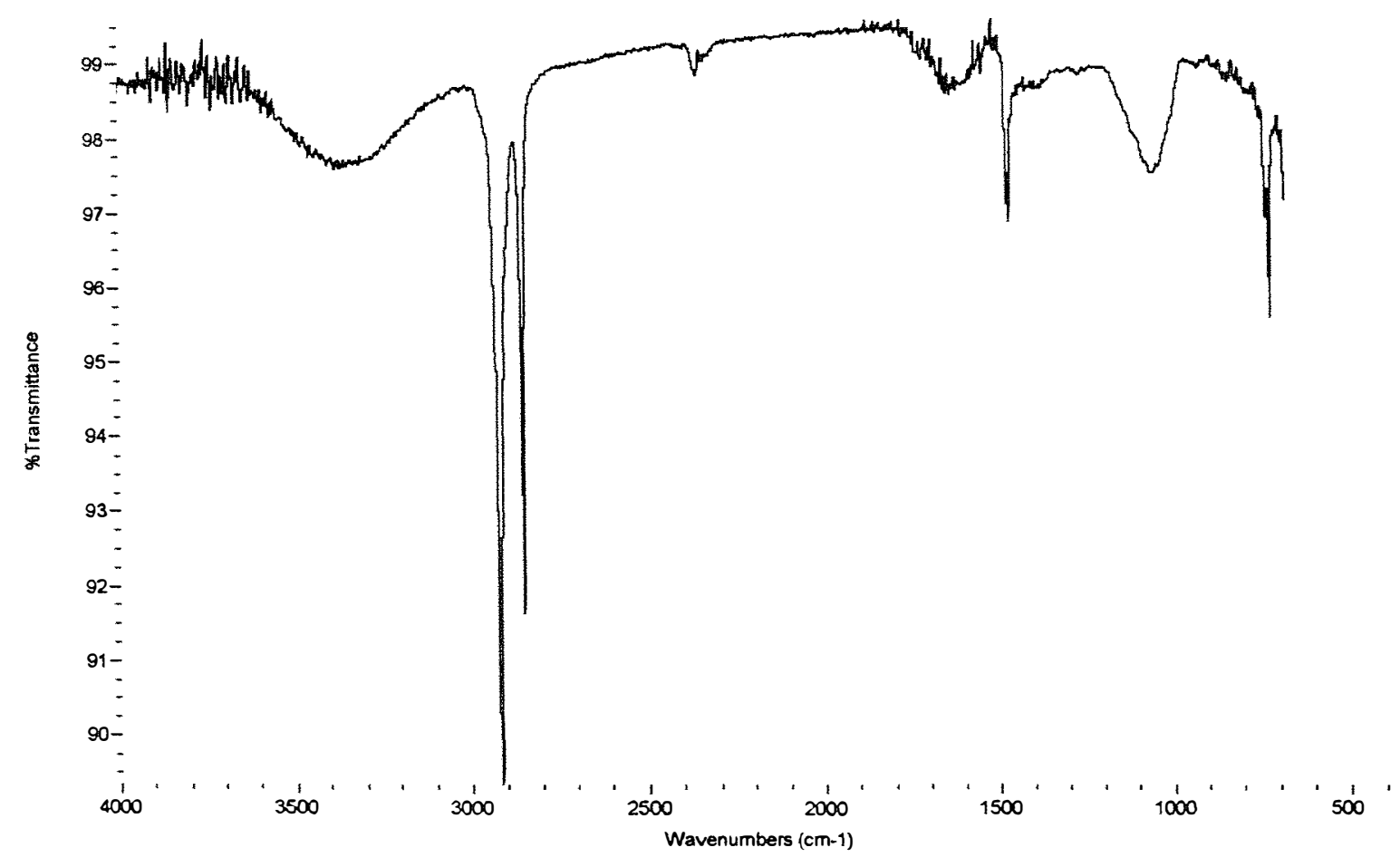

Figura 5.17 - Camada interna da amostra de suco após seis meses de envelhecimento na estufa - polietileno oxidado 


\section{DISCUSSÃO}

\subsection{Caracterização das Embalagens Multicamadas}

Conforme comentado no capítulo 4, a embalagem de leite protege o produto sem a necessidade de refrigeração, enquanto que a de suco precisa estar sob refrigeração adequada para que o produto não perca suas características. Por outro lado, para poder atender às necessidades destes produtos cada embalagem apresenta as seguintes peculiaridades: a embalagem de suco é feita com um cartão branqueado que está laminado interna e externamente por camadas de polietileno, enquanto que a embalagem de leite é feita com um cartão do tipo dupléx, com forro com pasta kraft não branqueado, que está laminado com alumínio e camadas de polietileno.

A função do cartão nestas embalagens é conferir propriedades de rigidez que se refletem no desempenho da mesma quando no empilhamento; qualidade de impressão (desempenho gráfico); baixa absorção de água pelas bordas laterais; e, para a embalagem de suco, boa retenção da resistência à úmido.

Assim, as caixas de leite têm responsabilidade na resistência à compressão, pois a embalagem de transporte é do tipo bandeja com o envolvimento de um filme encolhivel e que portanto, pouco colaboram com o desempenho no empilhamento das embalagens. O conjunto de caixas de leite devem ser submetidas ao ensaio de determinação da resistência à compressão 
dinamométrica, além de se considerar os fatores de segurança, tais como, temperatura e umidade do armazém, número de movimentações, acelerações do transporte, sendo especificado o número de caixas no empilhamento. A caixa aprovada neste ensaio, portanto, deve ter seu material caracterizado por ensaio de rigidez e absorção de água sob condições de umidade elevada, que servirão para a especificação e controle da qualidade do cartão.

No caso da embalagem de suco, o requisito de rigidez é exigido para o manuseio, pois esta embalagem não permite o empilhamento devido ao formato do topo da embalagem.

O valor de rigidez Lhomargy encontrado para embalagem de suco foi 29,0 N.mm (rigidez Taber $=14,8 \mathrm{~N} . \mathrm{mm}$ ) e para a embalagem de leite foi de $58,0 \mathrm{~N} . \mathrm{mm}$ (rigidez Taber $=29,6 \mathrm{~N} . \mathrm{mm}$ ). Estes valores comparados à cartões de mercado semelhantes em termos de gramatura total das embalagens (suco - $422 \mathrm{~g} / \mathrm{m}^{2}$ e leite $-356 \mathrm{~g} / \mathrm{m}^{2}$ ) e tomando-se por base que a gramatura dos outros substratos representam muito pouco em relação à do cartão, a rigidez Taber para um cartão do tipo duplex para congelados de $350 \mathrm{~g} / \mathrm{m}^{2}$ é de $21,5 \mathrm{~N} . \mathrm{mm}$ (ver Tabela 3.4 do capítulo 3), portanto a embalagem de leite apresenta valor de rigidez maior do que aquele citado na literatura. $O$ valor de rigidez da embalagem de suco não foi possível comparar porque não havia cartão branco de mesma gramatura. Também, não se pode concluir se estas embalagens estão atendendo a especificação de manuseio e empilhamento, pois somente testes desempenho poderiam avaliar estes aspectos. Cabe lembrar que se teve como objetivo neste trabalho obter valores de comparação tanto para os materiais originais como para aqueles que seriam submetidos aos ensaios de degradabilidade.

O bom desempenho gráfico é conferido para ambas as embalagens na superfície branqueada e lisa do cartão, além disso, a qualidade 
da impressão é mantida até o ponto de venda, pois o cartão está protegido pelo revestimento de uma camada de polietileno.

Os resultados, de ambas as amostras, mostram que a absorção lateral está dentro do esperado para cartões utilizados em embalagens de congelados $(6 \%)$, conforme dados coletados em catálogos de empresas nacionais (ver Tabela 3.4 do capítulo 3 ).

A retenção da resistência à úmido é requerida para embalagem de suco (produto refrigerado) que apresentou o valor de 0,91 ou $91 \%$ após duas horas de imersão em água. Para cartões nacionais utilizados em embalagens de produtos refrigerados, a resistência à úmido é de $80 \%$ (ver Tabela 3.3 do capítulo 3). Entretanto, não foi possível comparar estes resultados porque esta Tabela não explicita o tempo de imersão em água para esta propriedade.

As camadas de polietileno em ambas as embalagens conferem a impermeabilização da face interna e externa da embalagem e a soldabilidade. O revestimento externo é necessário para garantir, como dito anteriormente, a qualidade de impressão até o ponto de venda. O revestimento interno é, no caso da embalagem de leite a proteção da camada de alumínio do contato direto com 0 alimento que em certos casos (molhos) reage quimicamente, provocando a corrosão do alumínio. No caso da embalagem de suco, o revestimento interno impermeabiliza o cartão para que ele não absorva o líquido e perca a sua resistência, além da possibilidade de contaminação do suco. $O$ polietileno de baixa densidade linear (PEBDL), conforme identificação por espectrofotometria no infravermelho, na camada interna de ambas as embalagens, protege o produto da contaminação, pois é um polímero inerte e atóxico, além disso apresenta boas propriedades de barreira ao vapor d'água, resistência à ácidos, bases e óleos (ver Tabela 3.5 do capítulo 3). 
Como esperado, ambas as amostras não foram sensiveis ao método determinação da absorção de água pela face, visto que, estas amostras possuem revestimento de polietileno, ou seja, não era esperado que houvesse penetração de água pela face. Entretanto, para analisar melhor a absorção de água da embalagem foi realizado um teste não normalizado, onde três embalagens de cada amostra foram colocadas na cuba de inóx cheia de água na temperatura de $50^{\circ} \mathrm{C}$ por 72 horas.

Verificou-se através deste ensaio que a absorção de água em função do tempo da embalagem de suco é aproximadamente $30 \%$ maior do que a de leite. Astals (1996) relata que se a fibra da celulose é colocada em contato com a água absorve de 200 a $300 \%$ em peso. A sorção se efetua rapidamente em zonas amorfas da celulose através de mecanismos de adsorção ou de capilaridade.

A camada de alumínio da embalagem de leite é colocada para conferir a estrutura desta embalagem propriedades de barreira a luz e a gases, principalmente ao oxigênio. Esta barreira é a principal diferença entre as duas embalagens, pois ela que garante a embalagem de leite uma vida de prateleira maior e sem a necessidade de refrigeração. Entretanto, como visto na literatura, uma espessura mínima é requerida para que o alumínio exerça bem essas funções. A espessura da camada de alumínio da embalagem de leite é de $0,065 \mathrm{~mm}$ e atende a especificação citada por Hanlon (1971).

Existe também outra diferença, não menos importante, o tipo de cartão utilizado em cada embalagem. Na embalagem de suco o cartão é o branqueado e na de leite é do tipo dupléx, sendo esta diferença relevante no aspecto de degradação da embalagem. O cartão dupléx ainda apresenta lignina no forro, enquanto que o cartão branco não apresenta. A lignina é mais suscetível a degradação por ultravioleta do que a celulose (Gatenholm, 1996). A 
lignina também pode ser removida em soluções alcalinas através dos processos sulfato ou soda, conforme relata D'Almeida (1988).

\subsection{Ensaios de Degradabilidade}

\subsubsection{Degradabilidade por imersão em chorume}

$\mathrm{Na}$ caracterização do chorume, observou-se que os valores de DBO e DQO, antes deste estar em contato com a amostra, estão mais próximos daqueles analisados pela "Queiroz de Galvão" no dia 08.07.97. O pH encontrado na amostra inicial é verificado também nos resultados das análises realizadas pela "Queiroz de Galvão".

Surgiram diferenças significativas no chorume ao final do ensaio quanto aos aspectos de $\mathrm{DQO}, \mathrm{pH}$ e sólidos totais. Foi observado que no chorume, ao final do ensaio de degradabilidade, ainda na cuba de aço inoxidável, apresentava partes de materiais das embalagens que foram ensaiadas, principalmente fibras. Isto pode explicar o aumento de sólidos totais nesta amostra de chorume.

A Figura 6.1 mostra graficamente os resultados de variação de massa apresentados nas Tabelas 5.13 e 5.14. A amostra de embalagens de leite (seca) apresenta valores negativos, que significam que a perda de massa já começa a ocorrer a partir da $14^{\mathrm{a}}$ semana de imersão, bem antes da amostra de embalagens de suco.

Observou-se, também na Figura 6.1, que ao final do segundo mês ocorreu um acréscimo elevado de massa nas amostras Leite Seca e Suco Seca. Isto pode ser explicado pelas características de absorção apresentadas pelas amostras, geralmente ocorrendo lentamente pelas bordas não revestidas. 
Os dois tipos tiveram a tendência de perda de massa, no entanto somente a amostra de embalagem de leite mostrou efetivamente perda de massa.

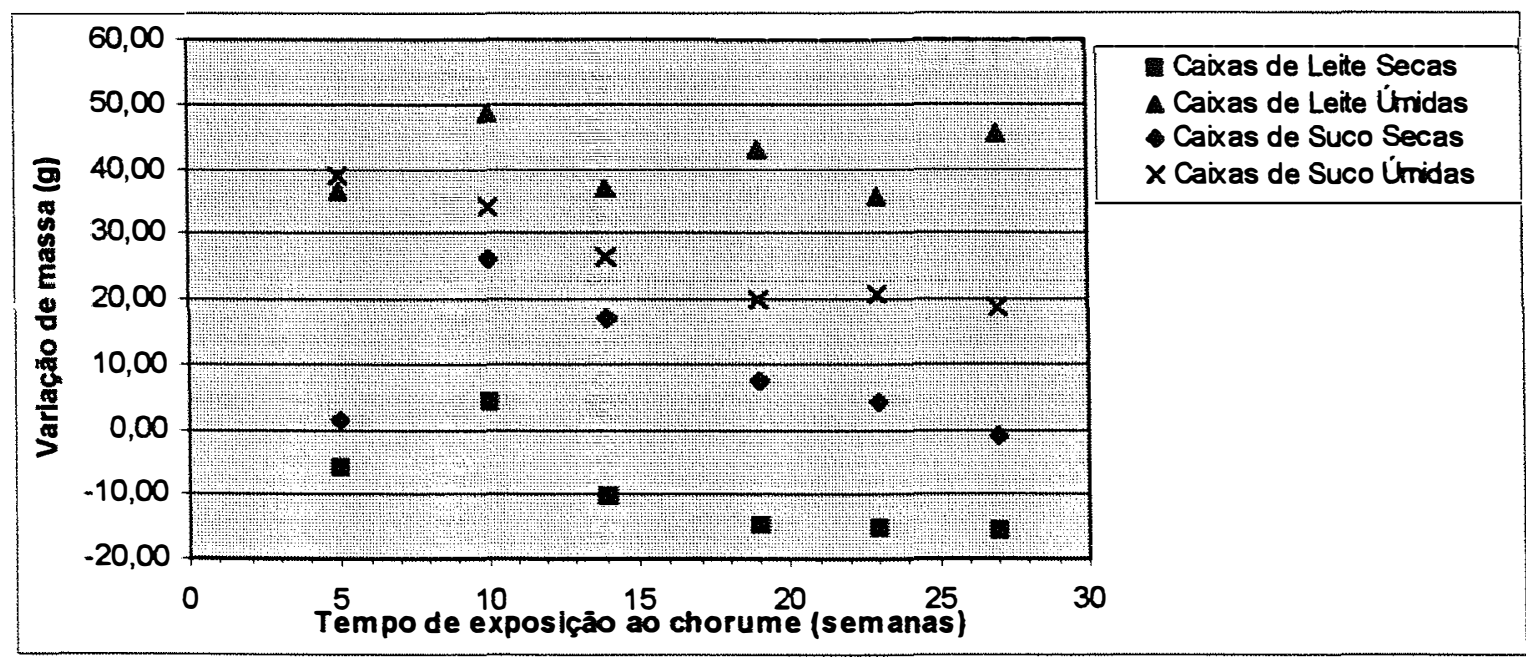

Figura 6.1 - Variação de massa de ambas as amostras na condição úmida e seca

O estado geral das amostras evidencia sua degradação, que pode ser verificada pelo exame visual. Para a amostra de embalagem de leite foi constatado que a deterioração acentuada começou a ocorrer a partir de 14 semanas (aproximadamente 3 meses) de imersão no chorume, pois a camada externa de polietileno estava delaminando, as fibras do cartão não recobriam mais todo o alumínio, deixando-o exposto, com acentuado escurecimento do cartão e amassamento (Foto 14). Para a amostra de embalagem de suco, no mesmo período, o aspecto de deterioração não se mostrou tão acentuado, embora tenham sido observadas delaminações das camadas nas regiões de solda lateral e bordas de topo, mostrando ainda perda de fibras do cartão nestas regiões (Foto 15). A coloração alaranjada da amostra de embalagens de suco é alterada para o tom amarelo claro a partir da amostra retirada após cinco semanas no chorume. 


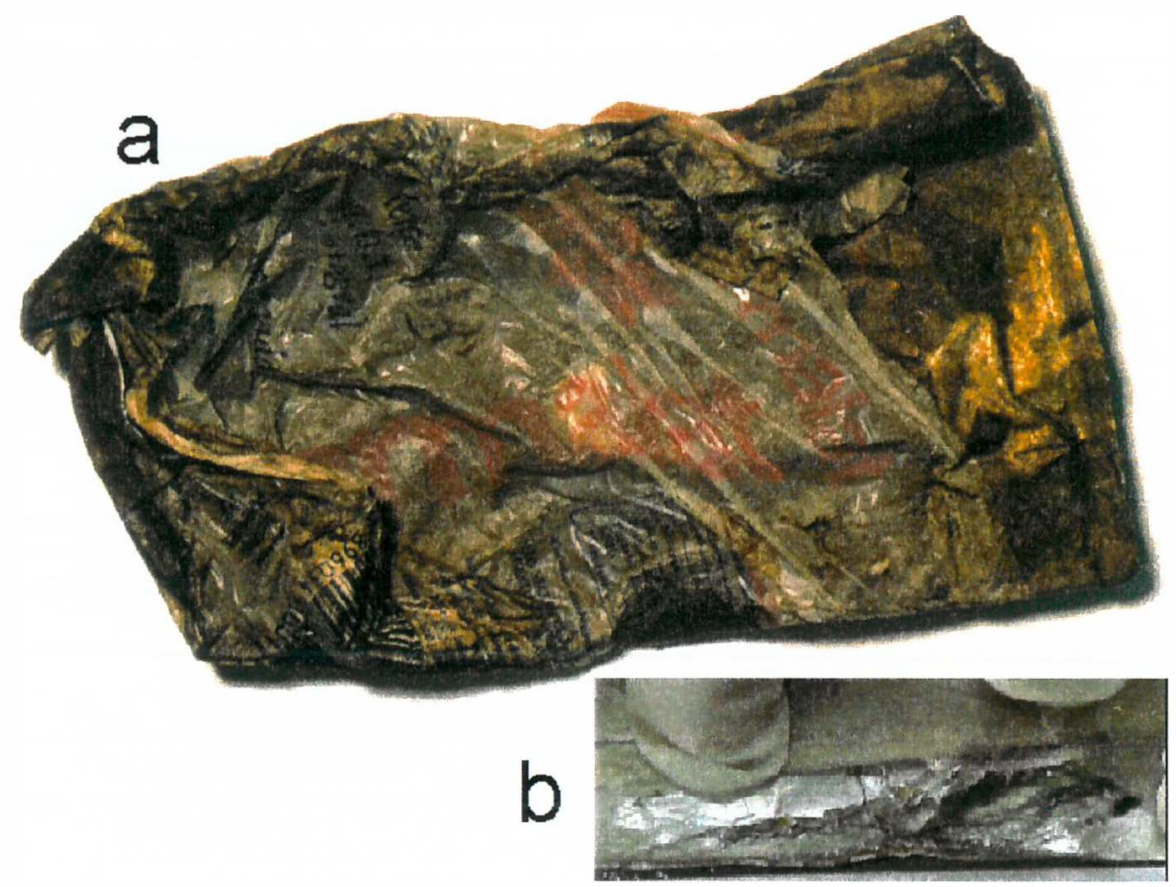

Foto 14 - (a) Embalagem de leite após três meses de imersão no chorume e (b) detalhe da oxidação do alumínio.

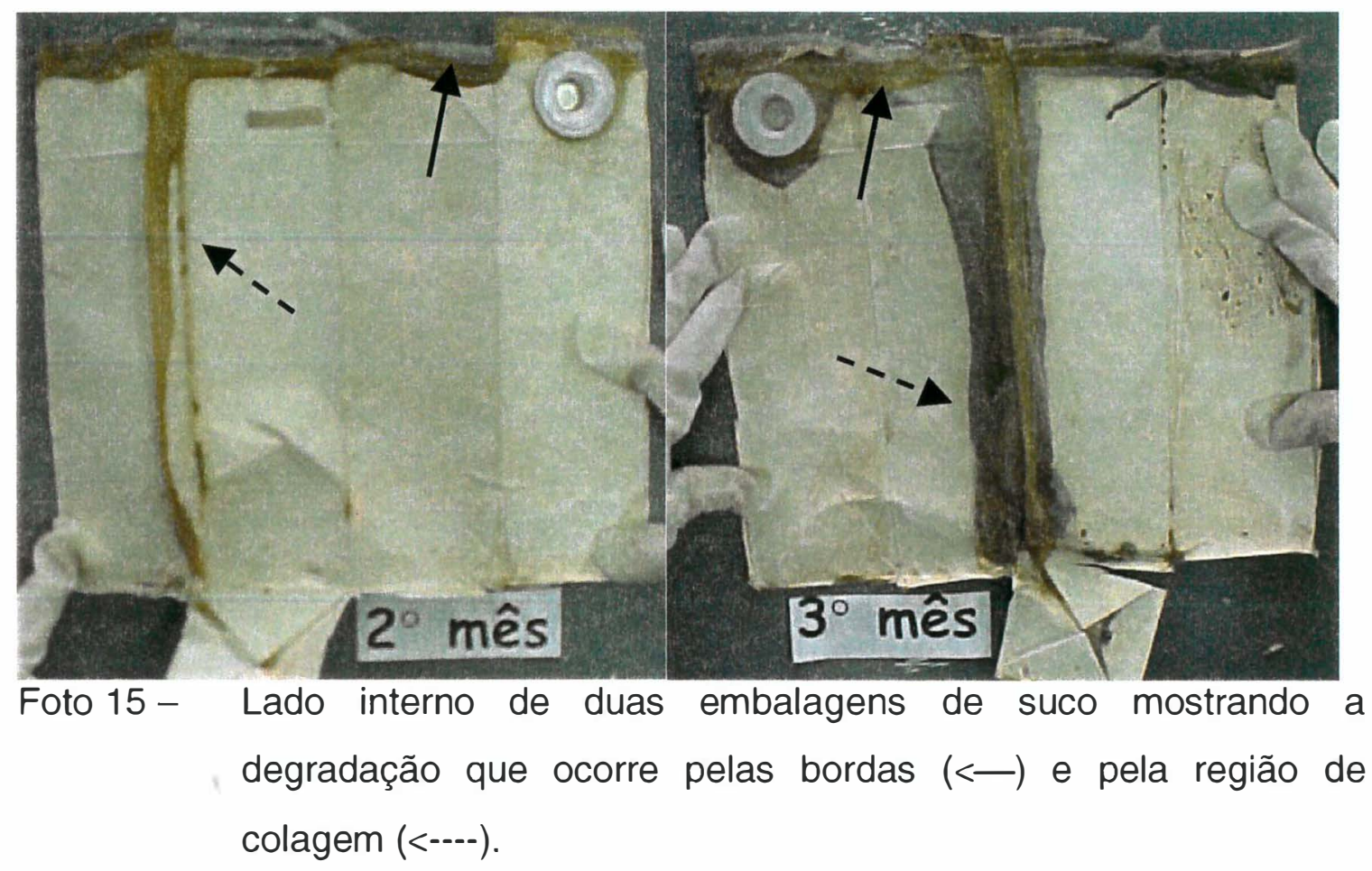


A Figura 6.2 mostra graficamente os resultados de tensão de ruptura da amostra de suco da Tabela 5.15.

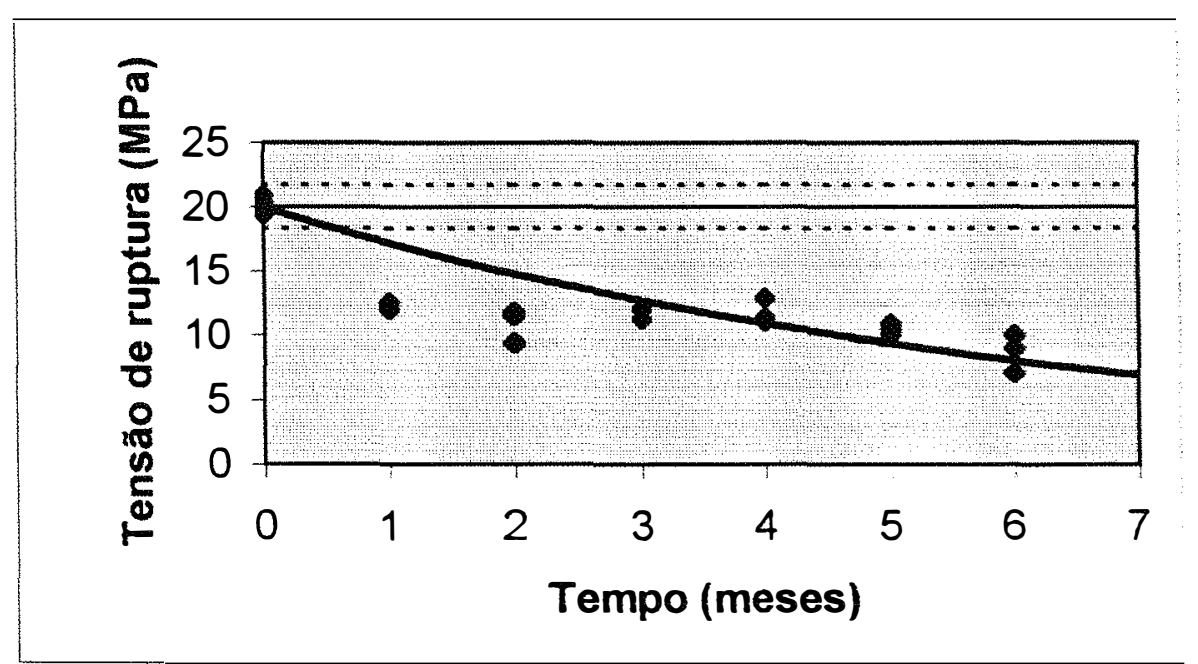

Figura 6.2 - Tensão de ruptura das amostras de suco envelhecidas no chorume. A linha reta contínua representa a média da amostra original e as linhas pontilhadas a dispersão $( \pm 3 \sigma)$ desta amostra. A linha curva contínua evidencia a tendência exponencial de degradação da amostra com o tempo.

A tendência exponencial da amostra de suco foi ajustada pela curva conforme equação 6.1 :

$$
T R=20,0 \exp \{-0,165 t\}
$$

onde:

$\mathrm{TR}=$ tensão de ruptura, em MPa

$t=$ tempo de exposição, em meses

A incerteza no coeficiente de $t$ é igual a 0,016 meses $^{-1}$ e no coeficiente TR é igual a 0,6 MPa. 
A vida média pode ser estimada a partir da equação 6.1 , ou seja, é inverso do coeficiente de t. O valor encontrado de vida média foi de 6,1 meses com desvio-padrão de 0,6 mês.

A Figura 6.3 mostra graficamente os resultados de tensão de ruptura da amostra de leite das Tabelas 5.16 e 5.17. Este gráfico inclui os resultados da amostra de leite originais no tempo " 0 ".

Pode-se notar, na Figura 6.3, que a amostra de leite perdeu cerca de $65 \%$ do valor original de tensão de ruptura logo no primeiro mês de imersão no chorume.

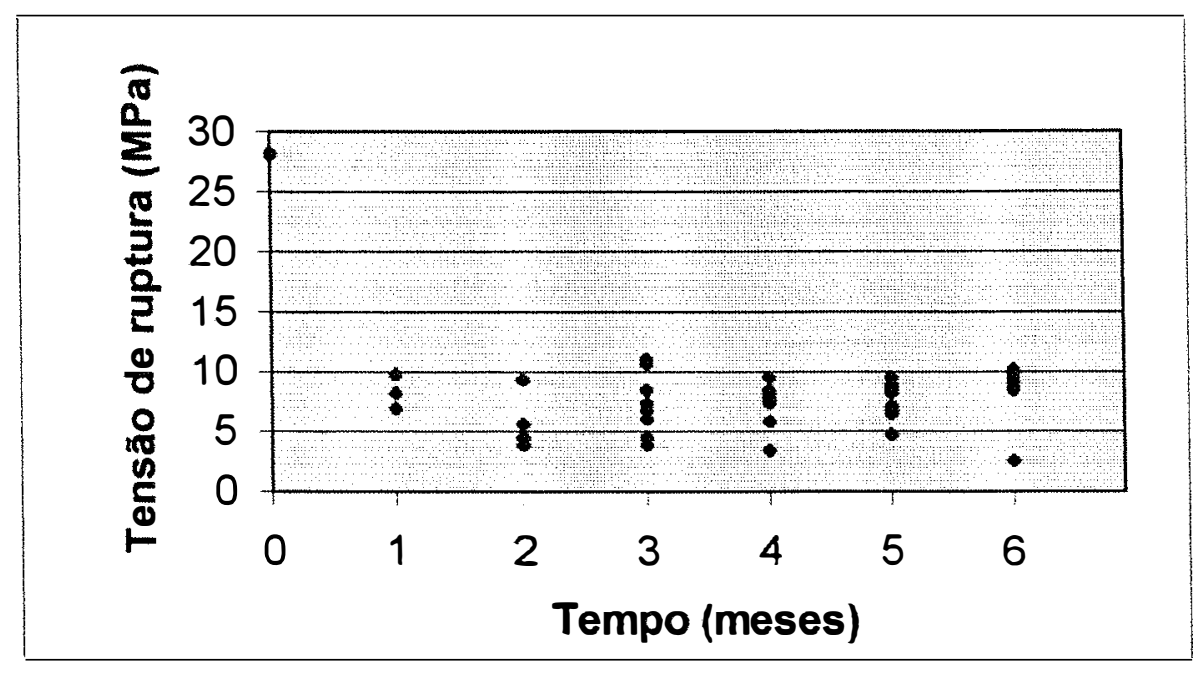

Figura 6.3 - Tensão de ruptura das amostras de leite envelhecidas no chorume, incluindo os dados originais no tempo " 0 ". 
A queda abrupta de tensão de ruptura para a amostra de embalagens de leite pode ter duas origens: (i) seu cálculo estar relacionado à largura e à espessura do corpo-de-prova, que como o material pode ter inchado com a absorção de líquido poderia não refletir uma perda de resistência à tração ou (ii) a resistência mecânica pode ter diminuído de fato devido a perda de fibras do cartão ou ainda à quebra das ligações entre fibras ou quebra das próprias fibras.

Na Figura 6.4 têm-se a variação de espessura desta amostra durante o período que ela ficou imersa no chorume. Vê-se que esta característica foi significativamente afetada neste tipo de ensaio principalmente a partir do terceiro mês. Já a perda de massa só foi verificada a partir de 14 semanas, conforme apresentado na Figura 6.1. Assim, estes dados permitem concluir que não foram estes fatores que provocaram a queda da tensão de ruptura no primeiro mês.

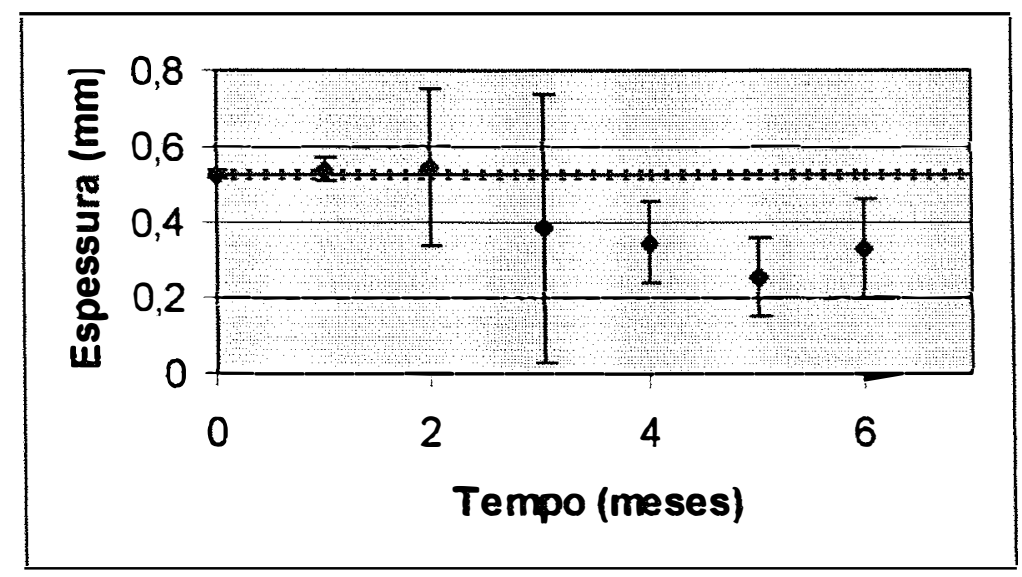

Figura 6.4 - Espessura da amostra de leite após imersão no chorume. A linha contínua representa a média da amostra original e as linhas pontilhadas a dispersão $( \pm 3 \sigma)$ desta amostra. As barras verticais representam a dispersão $( \pm 3 \sigma)$ de cada amostra envelhecida. 
Outros fatores, tais como as alterações químicas da celulose, podem ter contribuído para a perda de resistência mecânica ocorrida na amostra de embalagem de leite no primeiro mês. O cartão, componente responsável pela rigidez e resistência à tração, utilizado neste tipo de embalagem é do tipo duplex, possuindo um forro não branqueado, ou seja, possui ainda lignina residual e, conforme comenta D'Almeida (1988), pode ser alterada pelas condições alcalinas utilizadas neste ensaio. O aumento de DQO, de $3304 \mathrm{mg} / \mathrm{l}$ para $8578 \mathrm{mg} / \mathrm{l}$ (Tabela 5.11 ), durante o ensaio reforça a hipótese de degradação da lignina presente no cartão da embalagem, causando o prejuizo de suas características originais de resistência mecânica.

Outro aspecto, menos relevante, que pode ter contribuido para a grande perda de resistência mecânica da amostra de embalagem de leite com um mês de imersão no chorume, foram as alterações na estrutura química da camada polimérica, conforme mostrado na Figura 6.5. Nota-se ai a presença de uma banda na região de $1700 \mathrm{~cm}^{-1}$, característica de um grupo carbonila. Uma outra banda aparece próxima de $1000 \mathrm{~cm}^{-1}$, característica de grupos vinil com isomeria trans, e mais uma em $3400 \mathrm{~cm}^{-1}$, própria de hidroxilas. A literatura mostra que o surgimento destes grupos indicam a degradação do polietileno (Kelen, 1983).

As alterações na estrutura química de ambas as amostras após seis meses de imersão no chorume, conforme mostrado nas Figuras 5.6, 5.7, 5.8 e 5.9 são as mesmas relatadas acima e mostram a degradação do polietileno. Para a amostra de leite (camada externa) foi possivel verificar uma maior intensidade das bandas de oxidação com o aumento do período de imersão através da comparação dos espectros da Figuras 6.5 (1 mês) e 5.6 (6 meses). 


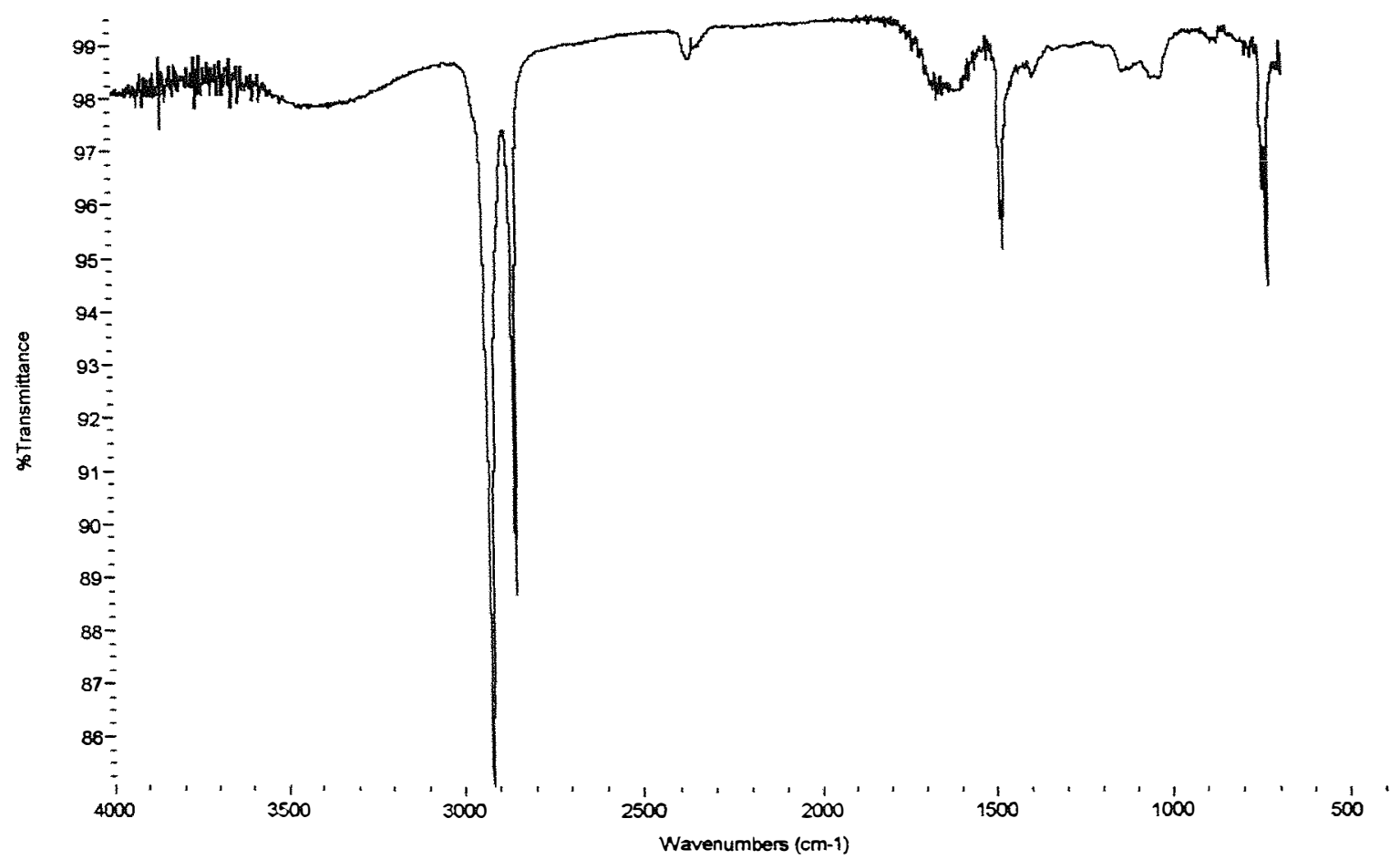

Figura 6.5 - Camada externa da amostra de leite com um mês de imersão no chorume - polietileno oxidado

\subsubsection{Degradabilidade por exposição à luz ultravioleta}

As amostras após a exposição à radiação ultravioleta e condensação mantiveram no geral o seu aspecto de novas, exceto pela perda de cor.

Os resultados da Tabela 5.18, estimativa de perda de cor pelo efeito da exposição à radiação ultravioleta e condensação das amostras de suco e leite, estão representados na Figura 6.6.

Ambas as amostras expostas a radiação ultravioleta tiveram um comportamento semelhante na perda da cor até 50 horas de exposição. 
Observa-se na Figura 6.6 que a partir de 50 horas, a amostra de suco teve maior perda de tonalidade (região da cor laranja) em relação ao material original do que a amostra de leite (região da cor vermelha).

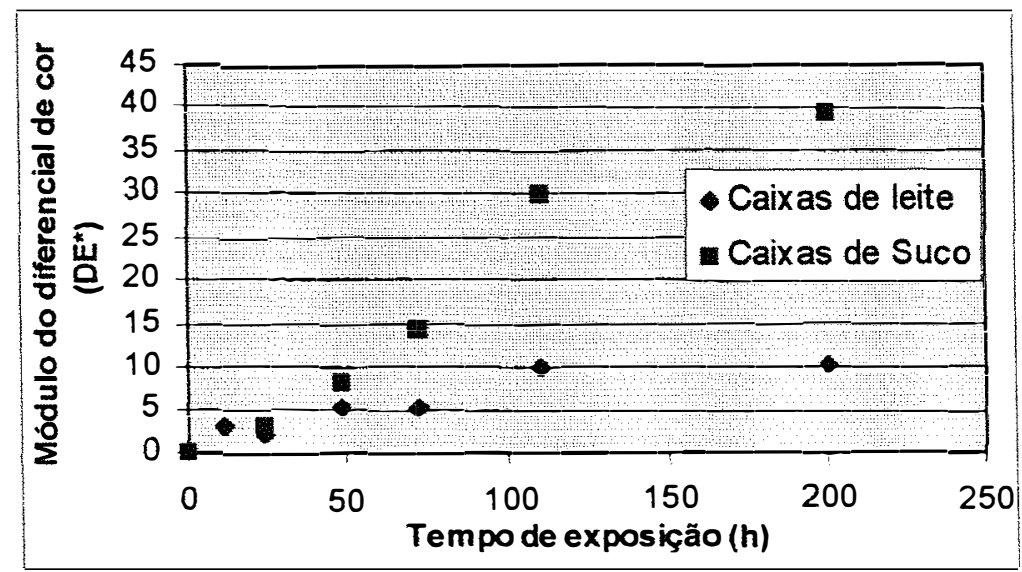

Figura 6.6 - Estimativa de perda de cor para ambas as amostras após exposição a luz ultravioleta com condensação.

As amostras que permaneceram na câmara de ultravioleta não apresentaram variação significativa de massa. Os valores finais médios de gramatura das embalagens foram de $435 \mathrm{~g} / \mathrm{m}^{2}$, para as de suco, e $366 \mathrm{~g} / \mathrm{m}^{2}$, para as de leite, conforme apresentado na Tabela 5.19 do capítulo anterior. Este valores estão dentro da variabilidade admissível para estruturas originais.

As Figuras 6.7 e 6.8 representam graficamente os resultados da Tabela 5.21, correspondentes aos valores de rigidez e módulo de elasticidade " $Z$ " da amostra de embalagem de suco. Estas amostras não foram significativamente afetadas quanto a propriedade de rigidez após a exposição de luz ultravioleta, conforme mostra a Figura 6.7. 


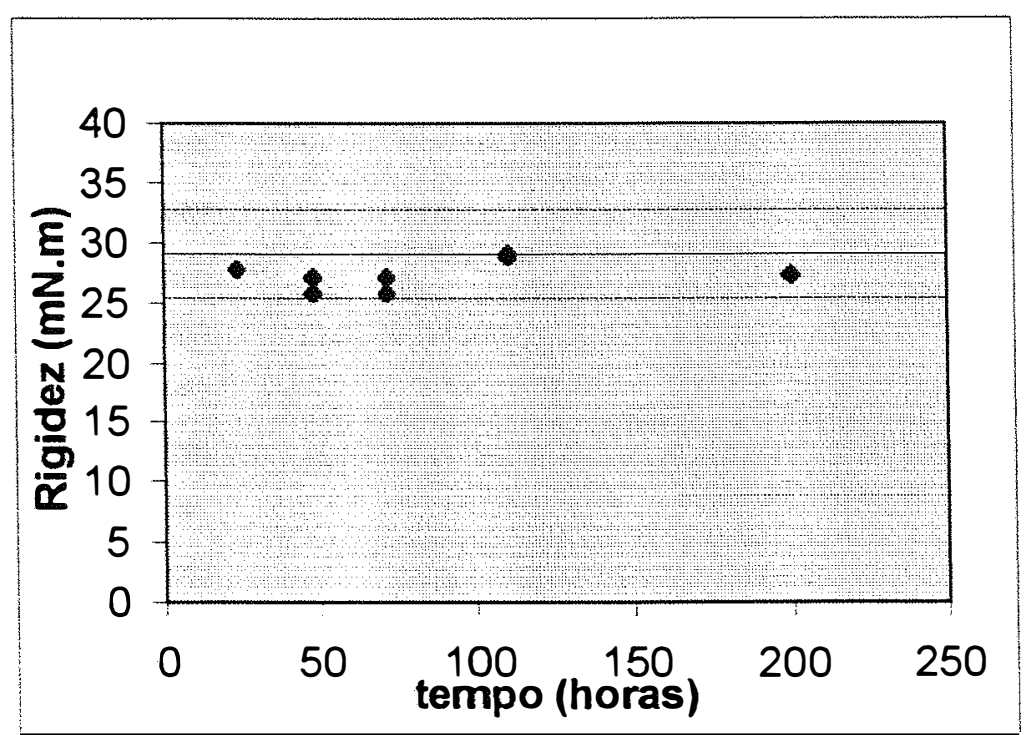

Figura 6.7 - Rigidez Lhomargy das amostras de suco envelhecidas na luz ultravioleta. A linha contínua representa a média da amostra original e as linhas pontilhadas a dispersão $( \pm 3 \sigma)$ desta amostra

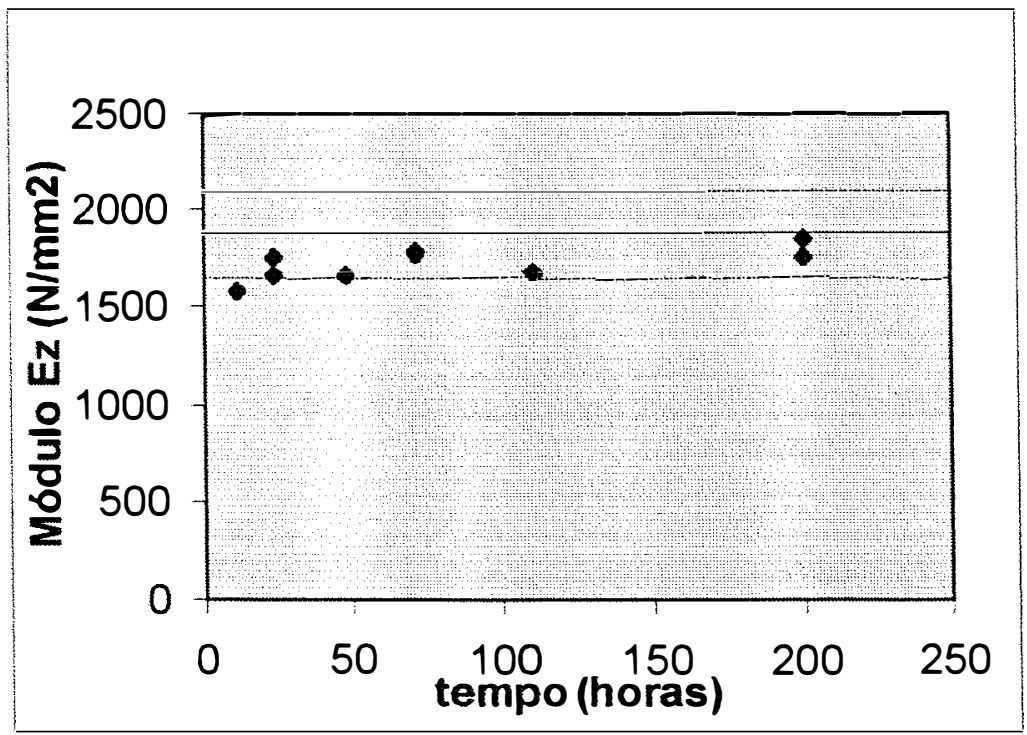

Figura 6.8 - Módulo de elasticidade na direção " $Z$ " das amostras de suco envelhecidas na luz ultravioleta. A linha contínua representa a média da amostra original e as linhas pontilhadas a dispersão $( \pm 3 \sigma)$ desta amostra 
As Figuras 6.9 e 6.10 representam graficamente os resultados da Tabela 5.20, correspondentes aos valores de rigidez e módulo de elasticidade " $Z$ " da amostra de embalagem de leite. Os resultados destes gráficos mostram uma tendência de queda nos valores de rigidez e módulo por estarem todos ligeiramente abaixo do valor médio da amostra, evidenciando melhor com 200 horas de exposição, a pesar de estarem dentro dos limites de dispersão da amostra.

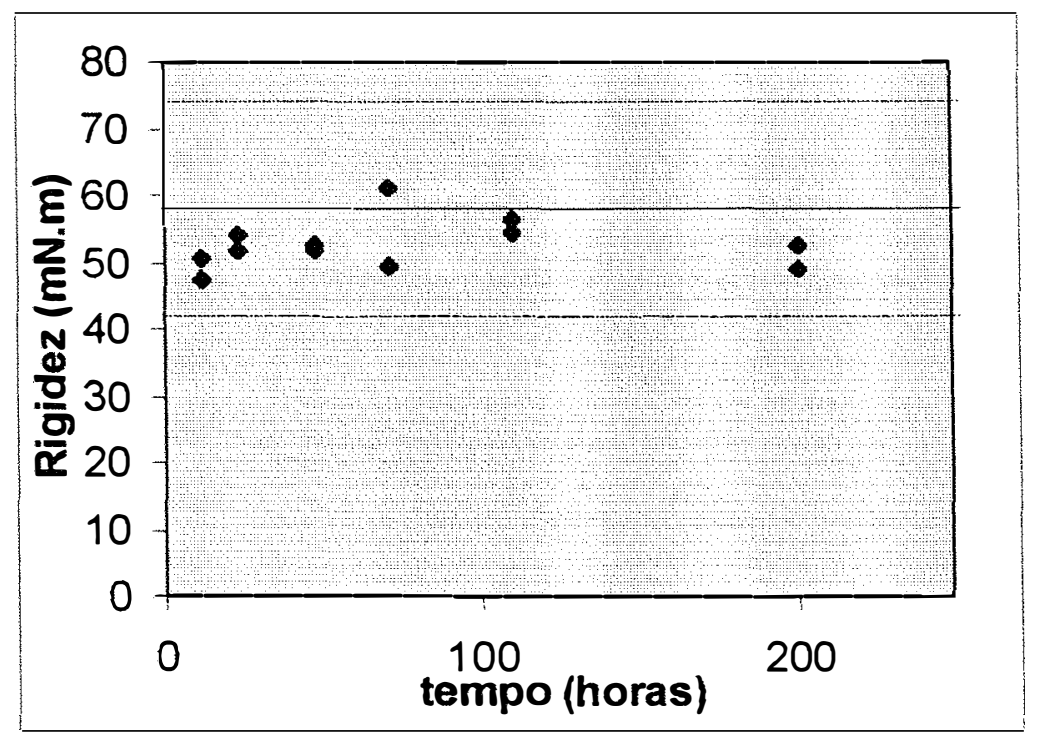

Figura 6.9 - Rigidez Lhomargy das amostras de leite envelhecidas na luz ultravioleta. A linha contínua representa a média da amostra original e as linhas pontilhadas a dispersão $( \pm 3 \sigma)$ desta amostra. 


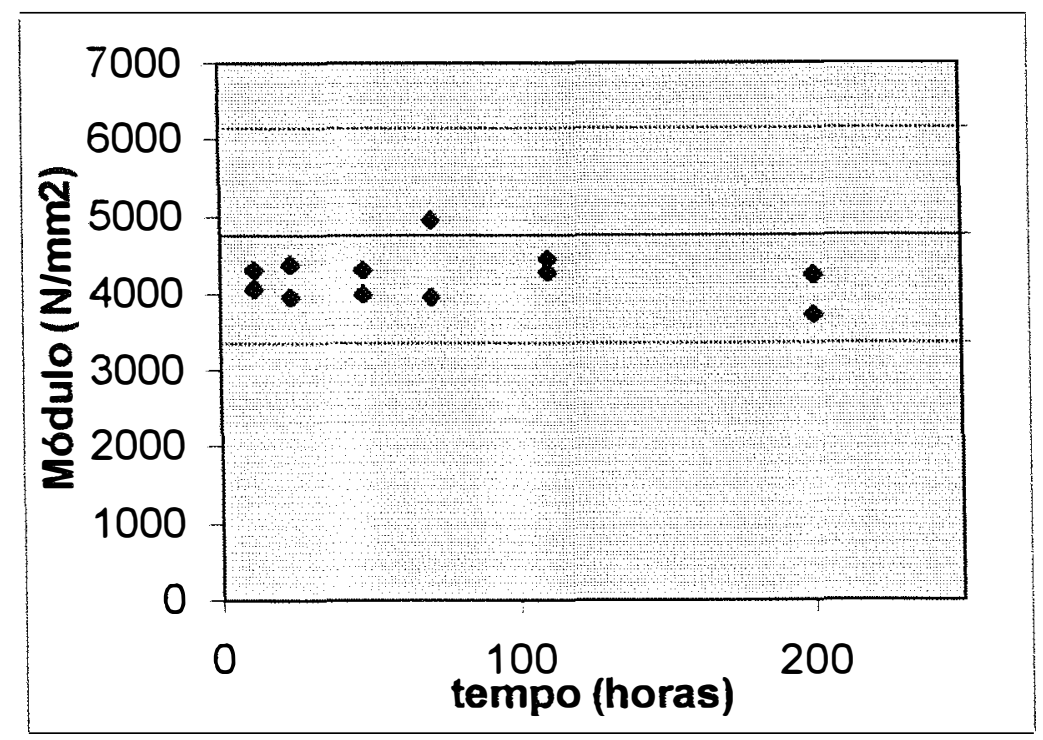

Figura 6.10 - Módulo de elasticidade na direção " $Z$ " das amostras de leite envelhecidas na luz ultravioleta. A linha contínua representa a média da amostra original e as linhas pontilhadas a dispersão $( \pm 3 \sigma)$ desta amostra.

As Figuras 6.11, 6.12 e 6.13 mostram graficamente os resultados da Tabela 5.22 referentes as embalagens de suco. Pode-se observar nestas figuras uma tendência de queda nas propriedades de tensão de ruptura, alongamento na ruptura e módulo de elasticidade destas amostras a partir de 110 horas de exposição na luz ultravioleta e tornando-se mais evidente com 200 horas de exposição. 


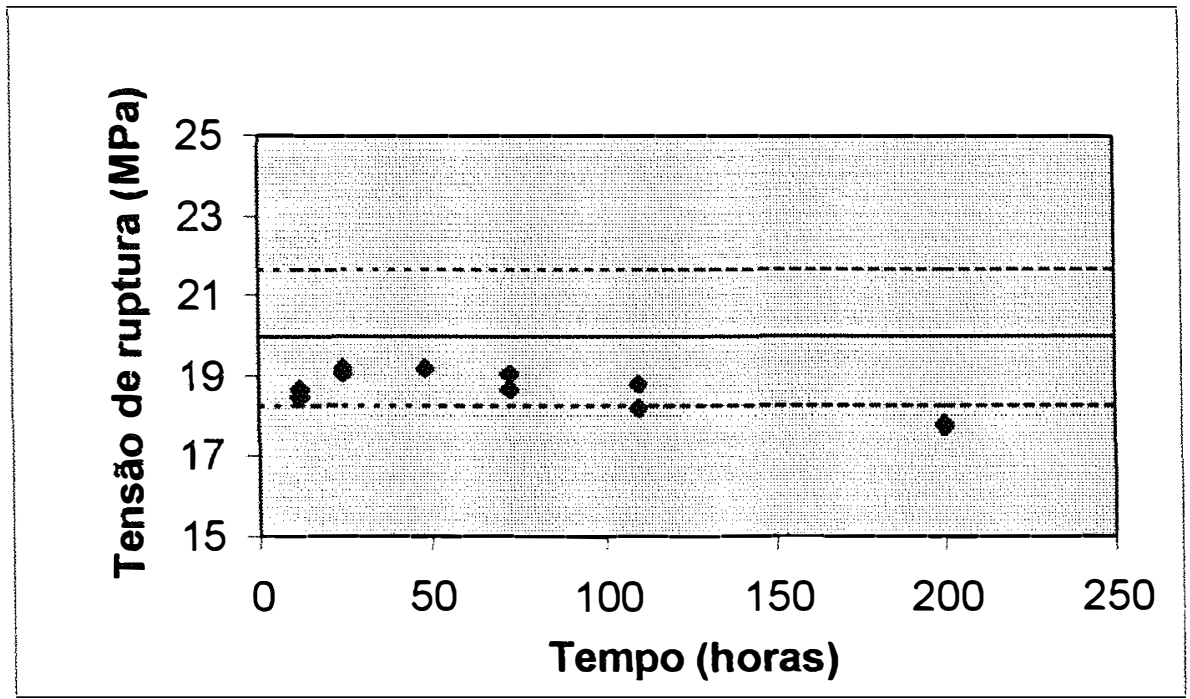

Figura 6.11 - Tensão de ruptura das amostras de suco envelhecidas na luz ultravioleta. A linha contínua representa a média da amostra original e as linhas pontilhadas a dispersão $( \pm 3 \sigma)$ desta amostra

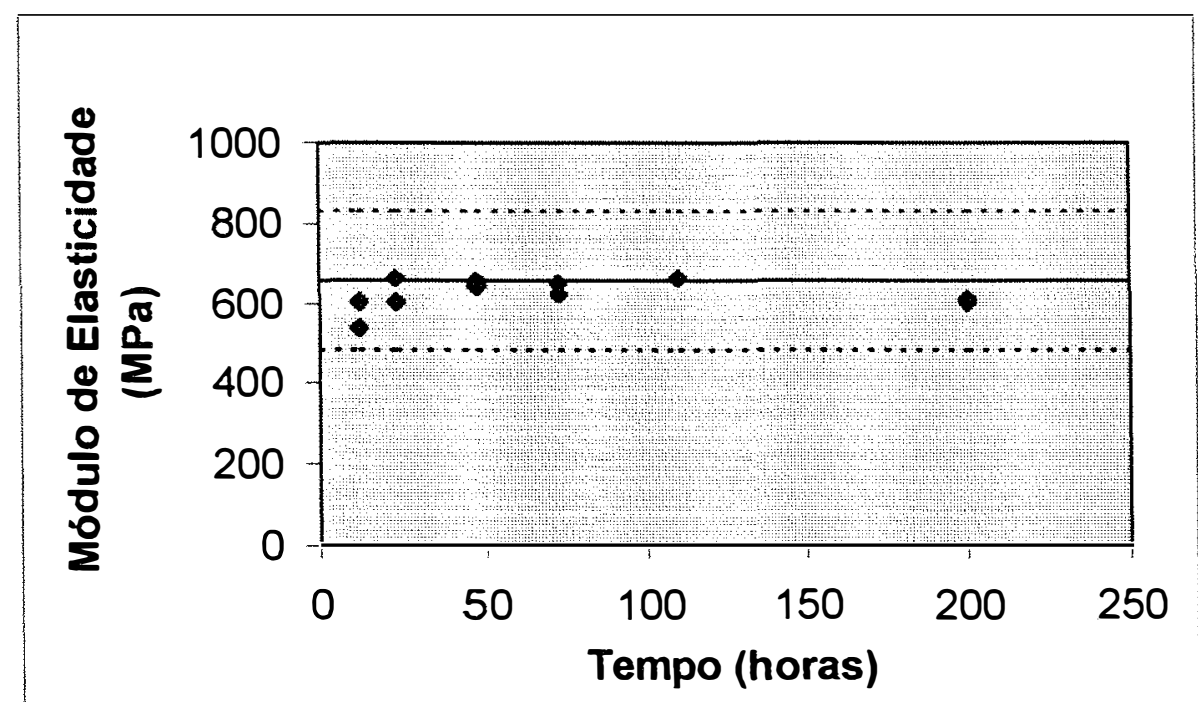

Figura 6.12 - Módulo de elasticidade das amostras de suco envelhecidas na luz ultravioleta. A linha contínua representa a média da amostra original e as linhas pontilhadas a dispersão $( \pm 3 \sigma)$ desta amostra 


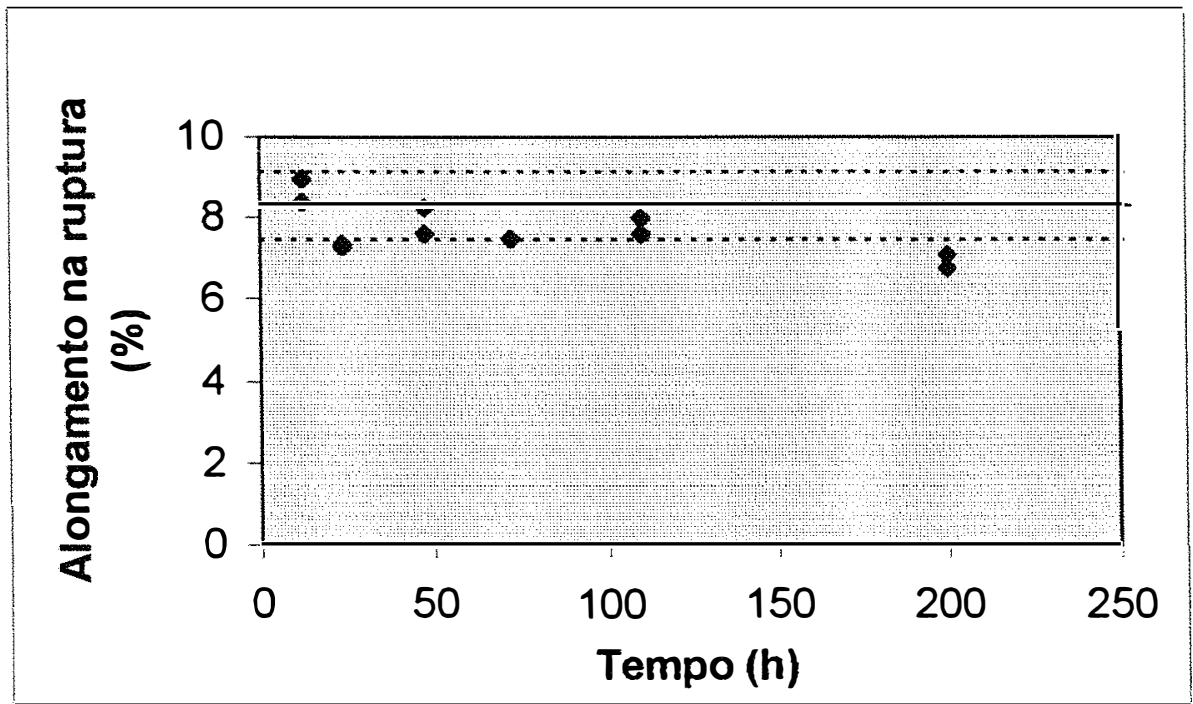

Figura 6.13 - Alongamento na ruptura das amostras de suco envelhecidas na luz ultravioleta. A linha contínua representa a média da amostra original e as linhas pontilhadas a dispersão $( \pm 3 \sigma)$ desta amostra

As Figuras $6.14,6.15$ e 6.16 mostram graficamente os resultados da Tabela 5.23 referentes as embalagens de leite. A tendência exponencial de degradação desta amostra foi ajustada pela curva conforme equação 6.2 obtida com os dados da Figura 6.14.

$$
T R=35,6 \exp \{-0,0023 t\}
$$

onde:

$\mathrm{TR}=$ tensão de ruptura, em $\mathrm{MPa}$

$t=$ tempo de exposição, em horas

A incerteza no coeficiente de $t$ é igual a $0,0003 h^{-1}$ e no coeficiente TR é igual a 1,5 MPa.

A vida média estimada a partir do coeficiente de $t$ da equação 6.2 é de 441 h com desvio-padrão de $65 \mathrm{~h}$. 


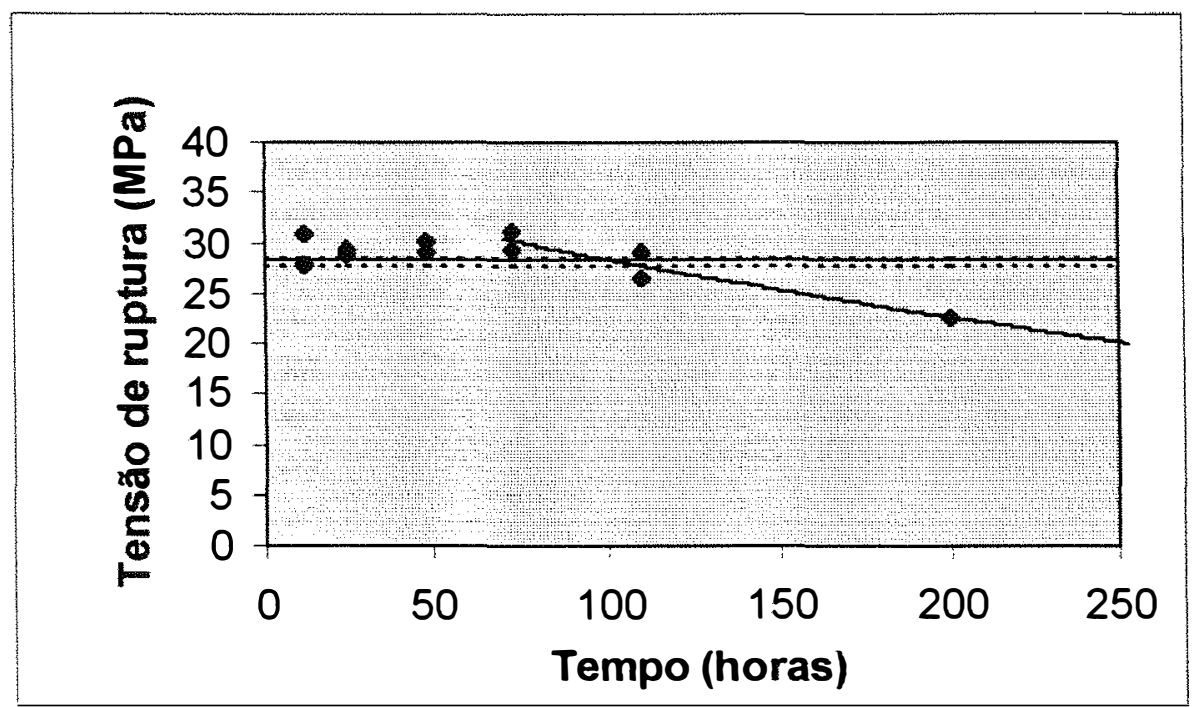

Figura 6.14 - Tensão de ruptura das amostras de leite envelhecidas na luz ultravioleta. A linha reta contínua representa a média da amostra original $e$ as linhas pontilhadas a dispersão $( \pm 3 \sigma)$ desta amostra. A linha curva contínua evidencia a tendência exponencial de degradação da amostra com o tempo a partir de 70 horas de exposição.

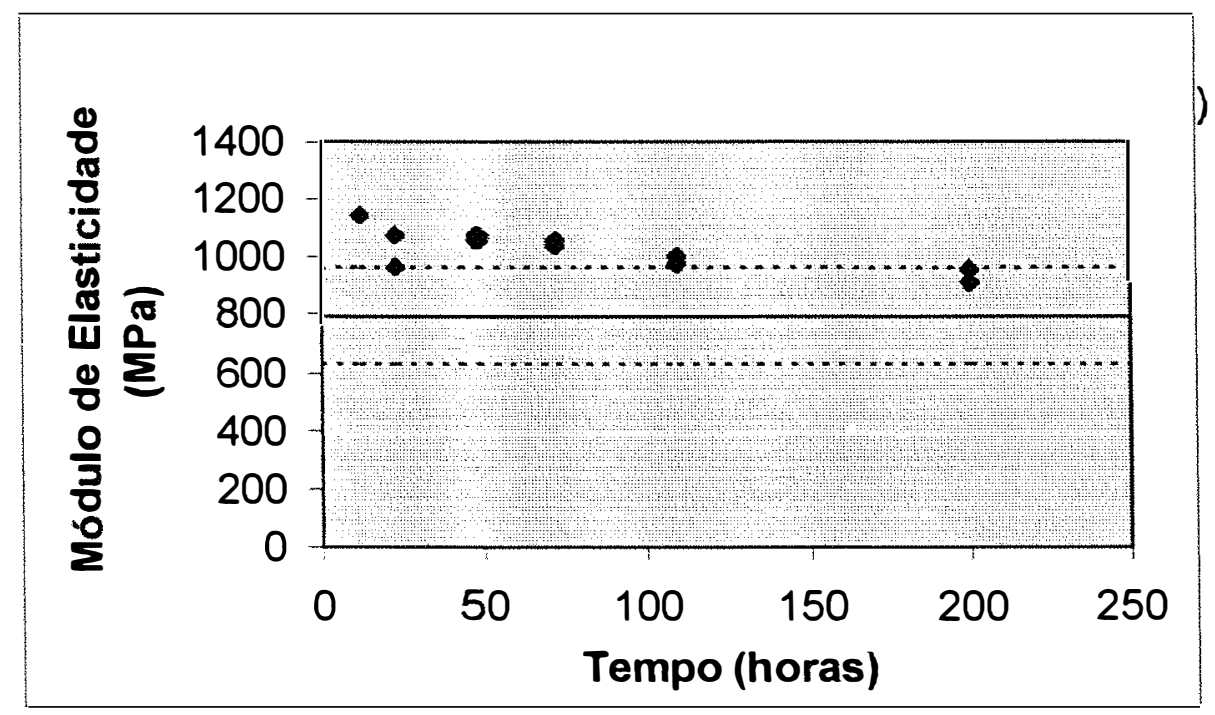

Figura 6.15 - Módulo de elasticidade das amostras de leite envelhecidas na luz ultravioleta. A linha contínua representa a média da amostra original e as linhas pontilhadas a dispersão $( \pm 3 \sigma)$ desta amostra. 


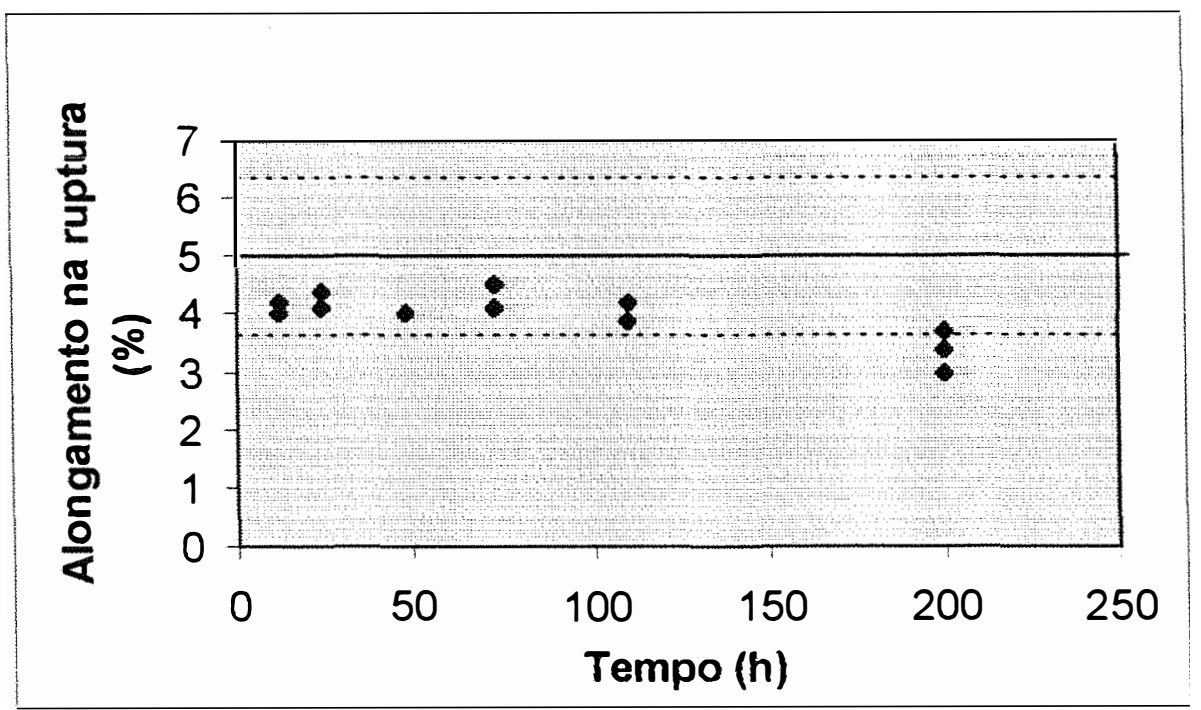

Figura 6.16 - Alongamento na ruptura das amostras de leite envelhecidas na luz ultravioleta. A linha contínua representa a média da amostra original $e$ as linhas pontilhadas a dispersão $( \pm 3 \sigma)$ desta amostra.

As Figuras mostraram que as propriedades de tensão de ruptura e alongamento para as amostras de embalagem de leite apresentaram tendência de queda, mas os valores de módulo de elasticidade estiveram sempre acima da média da amostra, somente a partir de 70 horas começou apresentar uma tendência de queda nos valores. Este fato, pode contribuir para outros estudos que avaliem a viabilidade econômica de um processo que utilize a radiação ultravioleta para a melhora das características deste tipo de cartão.

A camada externa de polietileno da embalagem de suco apresentou no espectro de infravermelho, conforme mostra a Figura 5.10 do capítulo anterior, uma banda de um grupo carbonila evidenciando a degradação do polímero por fotooxidação e termooxidação já que estava sob radiação ultravioleta e condensação à $60^{\circ} \mathrm{C}$, confirmando dados da literatura (ver item 3.3.5.1 do capítulo 3). 
A camada externa de polietileno da embalagem de leite não evidenciou uma banda de oxidação do polietileno no espectro, conforme mostra a Figura 5.11. No entanto, a ocorrência desta degradação não deve ser descartada já que esta técnica (espectrofotometria no infravermelho) pode não ter a sensibilidade necessária para detectá-la.

\subsubsection{Degradabilidade por exposição às intempéries}

Os dados da amostra de suco retirada com seis meses de envelhecimento no intemperismo natural serão excluídos da análise de resultados, porque, como dito anteriormente, ela foi substituída por outra. Os resultados desta amostra de suco representa um período de intempéries diferente das demais e por conseguinte um comportamento incomparável aos das outras. Entretanto, esta indica que o período de exposição afeta os resultados.

Quanto aos resultados de gramatura das amostras expostas às intempéries, estes são mostrados graficamente na Figura 6.17. A amostra de embalagens de leite apresenta valores muito inferiores ao valor médio de gramatura $\left(356 \mathrm{~g} / \mathrm{m}^{2}\right)$, que significam que a perda de massa ocorre a partir da 5 meses de exposição, enquanto que a amostra de embalagens de suco não apresenta. 


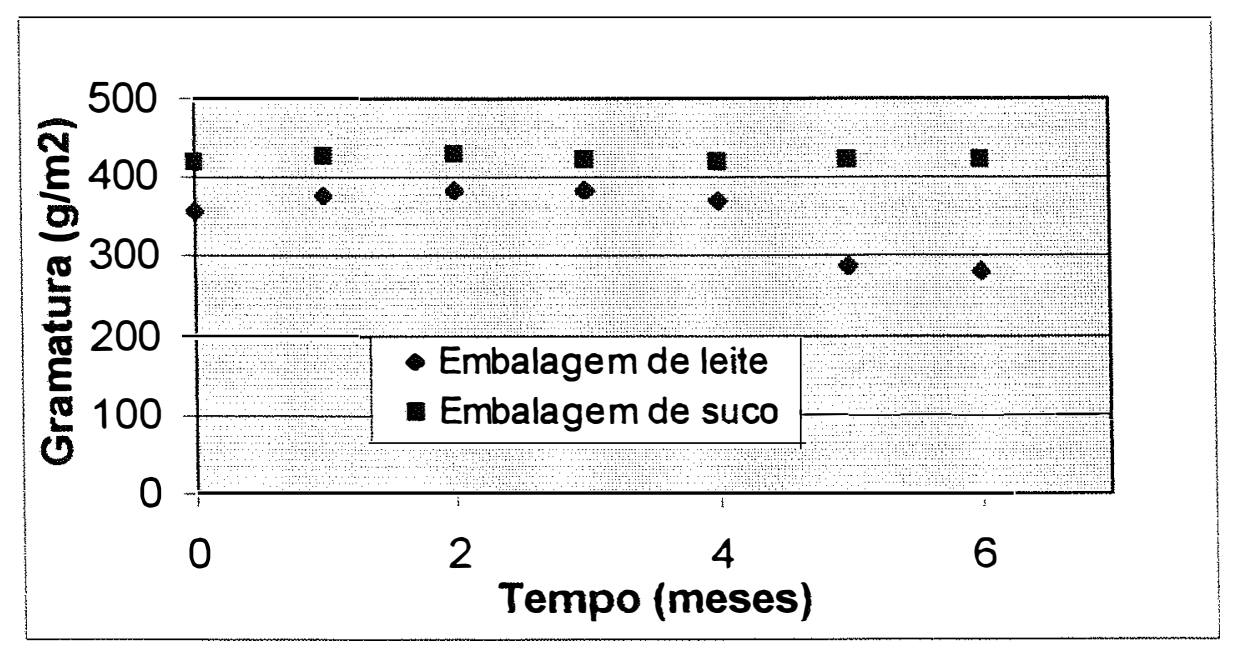

Figura 6.17 - Gramatura em função do tempo de ambas as amostras no envelhecimento de intemperismo natural.

O exame visual revelou que na amostra de embalagem de leite ocorreu uma deterioração acentuada a partir de 5 meses de exposição às intempéries, pois a camada externa de polietileno foi removida quase totalmente, as fibras do cartão foram parcialmente arrancadas, impossibilitando a leitura da impressão e expondo a camada de forro não branqueada do cartão, entretanto o alumínio se manteve protegido (Foto 16).

Para a amostra de embalagem de suco, no mesmo período, o aspecto de deterioração não se mostrou tão acentuado, embora tenham sido observadas trincas da camada externa de polietileno e acentuada perda de coloração (o tom laranja desaparece desde o primeiro mês), Foto 17 (o amassamento ocorrido não foi pela exposição, mas devido ao desprendimento do painel). 


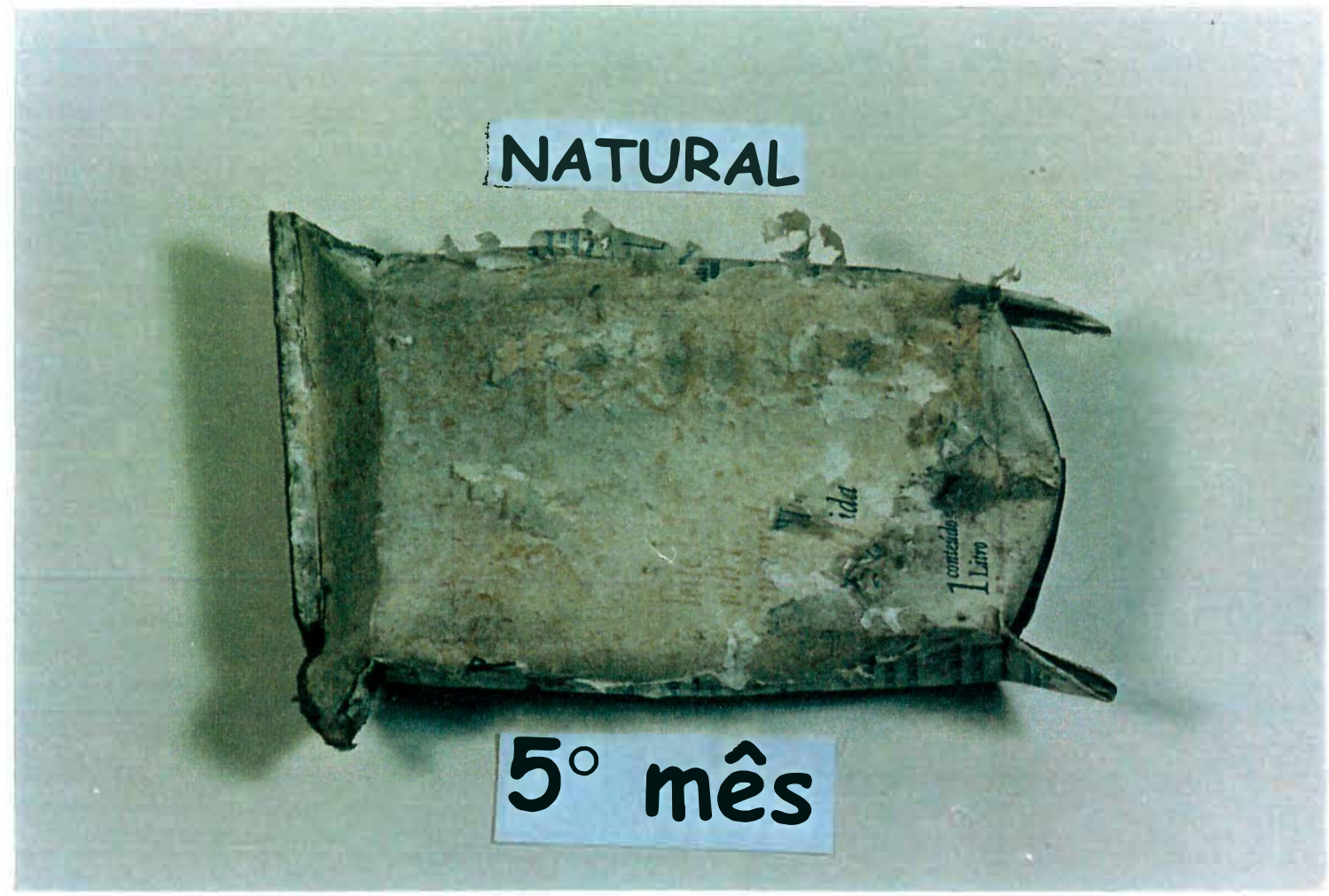

Foto 16 - Embalagem de leite após cinco meses de exposição às intempéries.

\section{NATURAL}

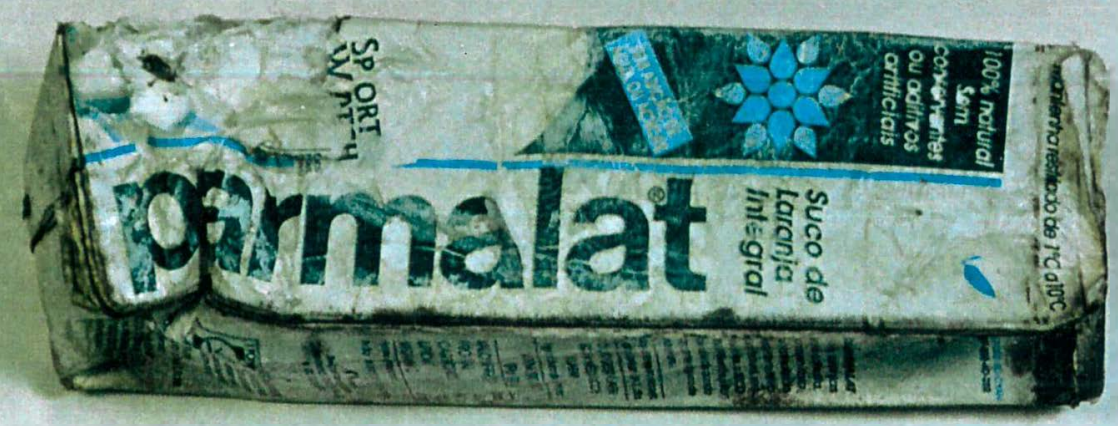

\section{$5^{\circ}$ mês}

Foto 17 - Embalagem de suco após cinco meses de exposição às intempéries. 
As Figuras 6.18 e 6.19 representam graficamente os resultados da Tabela 5.26 referentes ao módulo de elasticidade " $Z$ " e rigidez das amostras da embalagem de suco. Estas Figuras evidenciam a perda desta propriedade nesta amostra.

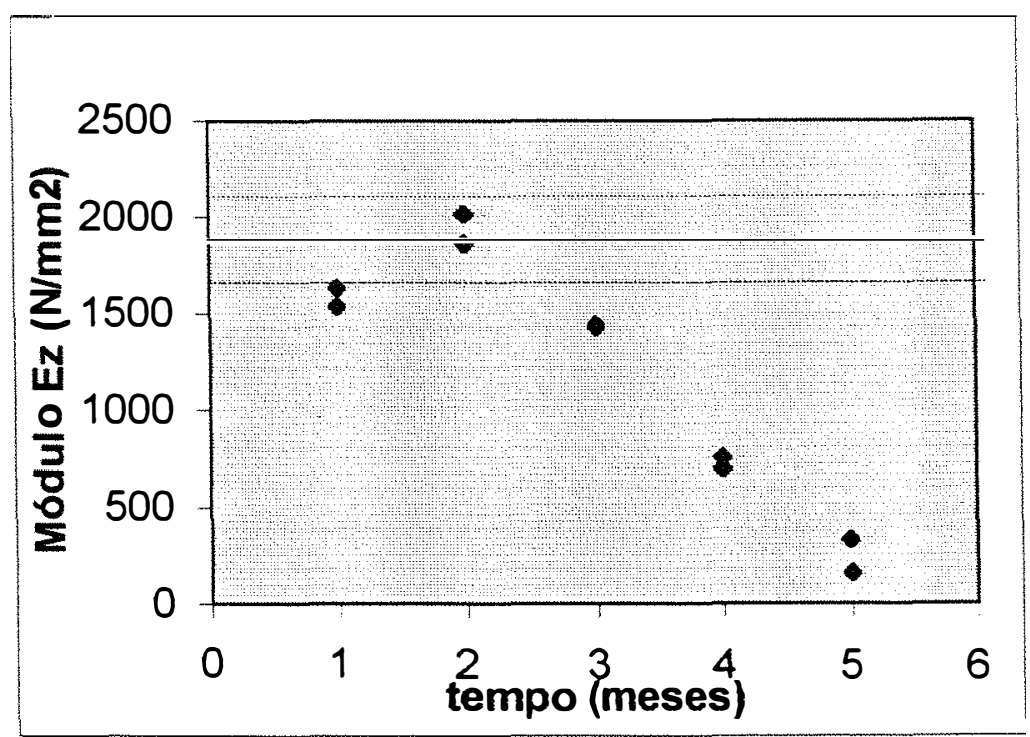

Figura 6.18 - Módulo de elasticidade na direção "Z" das amostras de suco envelhecidas no intemperismo natural. A linha contínua representa a média da amostra original e as linhas retas pontilhadas a dispersão $( \pm 3 \sigma)$ desta amostra. 


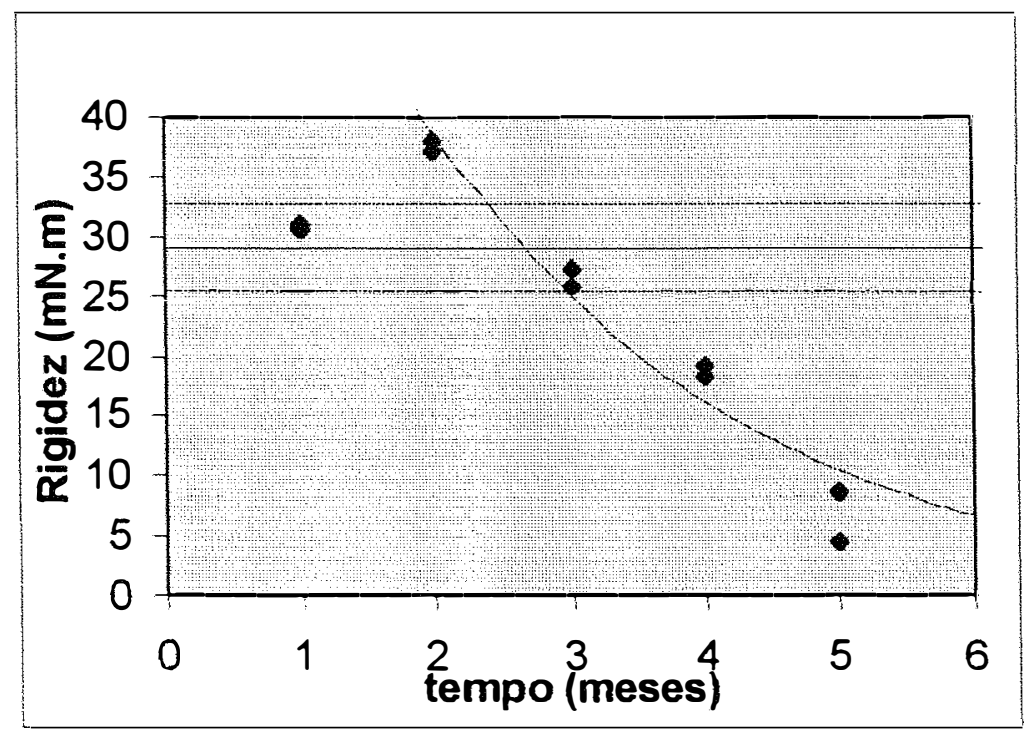

Figura 6.19 - Rigidez Lhomargy das amostras de suco envelhecidas no intemperismo natural. A linha contínua e reta representa a média da amostra original e as linhas retas pontilhadas a dispersão ( \pm 3б) desta amostra. A linha curva pontilhada evidencia a tendência exponencial de degradação da amostra com o tempo, a partir do segundo mês.

A tendência exponencial de degradação da amostra de suco foi ajustada pela curva conforme equação 6.3:

$$
R=91,9 \exp \{-0,434 t\}
$$

onde:

$$
\begin{aligned}
& R=\text { rigidez Lhomargy } \\
& T=\text { tempo de exposição }
\end{aligned}
$$

A incerteza no coeficiente de $t$ é igual a 0,053 meses $^{-1}$ e no coeficiente $R$ é igual a $13 \mathrm{mN}$.m. A vida média pode ser estimada a partir do coeficiente de t pela fórmula da equação 6.3. O valor encontrado de vida média foi de 2,3 meses com desvio-padrão de 0,1 mês a partir do segundo mês, portanto a vida média é da ordem de 4,3 meses. 
Para analisar os dados da Figura 6.19, onde ocorreu uma elevação nos dados iniciais (primeiro e segundo mês) de rigidez, é necessário relembrar que a variação de umidade do meio ambiente promove aiteraçōes no valor da espessura da folha de papel devido à absorção (ou dessorção) de água pela mesma e que a rigidez é uma função quadrática (e cúbica) da espessura (D'Almeida, 1997). Portanto, a exposição às chuvas fez com que a amostra adquirisse umidade e ficasse mais espessa, conforme mostra a Figura 6.20 , elevando os valores de rigidez nestes períodos.

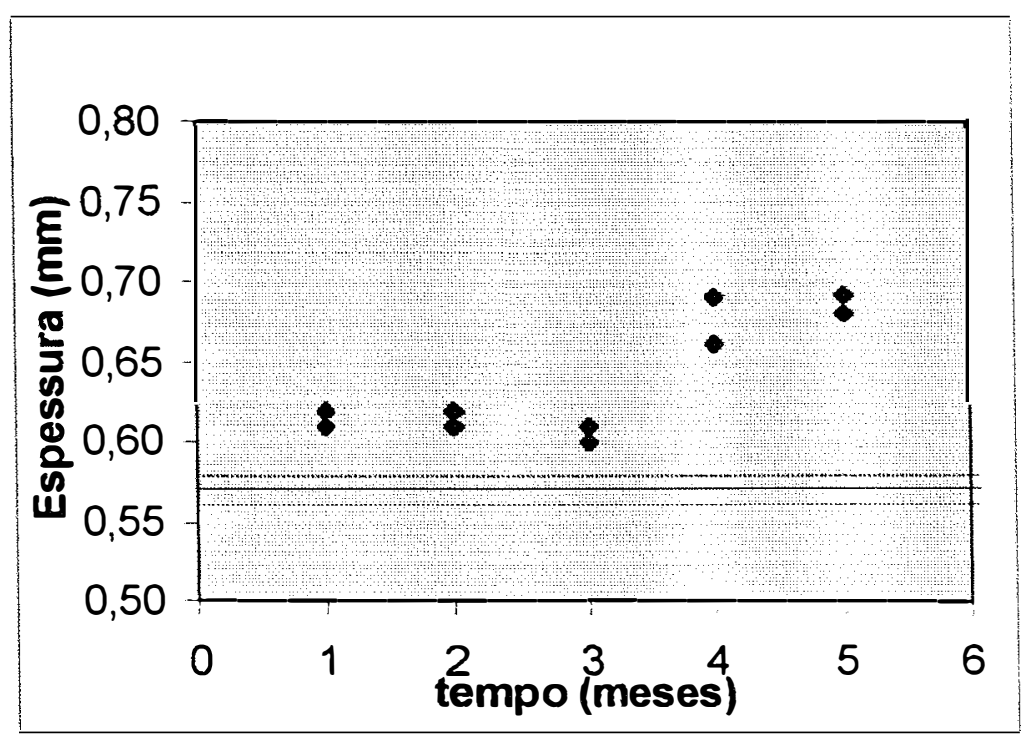

Figura 6.20 - Espessura dos corpos-de-prova utilizados no ensaio de determinação da rigidez Lhomargy das amostras de suco envelhecidas no intemperismo natural.

Na Figura 6.20 observa-se, também, um aumento significativo de espessura nos períodos de 4 e 5 meses de exposição, isto pode ser explicado pela elevação da precipitação neste período (ver Tabela 4.1). Entretanto, os valores de rigidez decaem a partir do terceiro mês mesmo com a elevada espessura, demonstrando a perda de resistência mecânica do material 
devido a perda de fibras do cartão ou ainda à quebra das ligações entre fibras ou quebra das próprias fibras.

As Figuras 6.21 e 6.22 representam graficamente os resultados da Tabela 5.25 referente ao módulo de elasticidade " $Z$ " e rigidez das amostras da embalagem de leite. Observou-se na Tabela 5.25 que ao contrário da amostra de suco, a pequena elevação da espessura não reflete no aumento de rigidez. Esta amostra quando exposta às intempéries perde significativamente a rigidez no quinto mês. Um dos principais fatores da perda de resistência neste mês de exposição é a significativa perda de massa, conforme visto na Figura 6.17 .

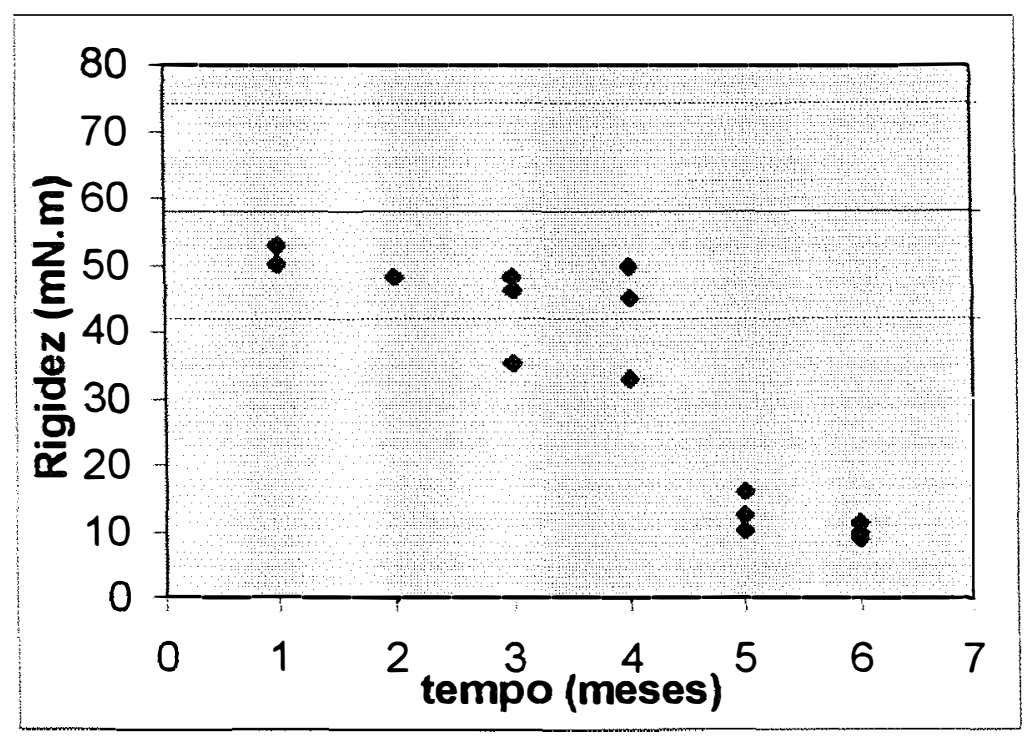

Figura 6.21 - Rigidez Lhomargy das amostras de leite envelhecidas no intemperismo natural. A linha contínua representa a média da amostra original e as linhas pontilhadas a dispersão $( \pm 3 \sigma)$ desta amostra. 


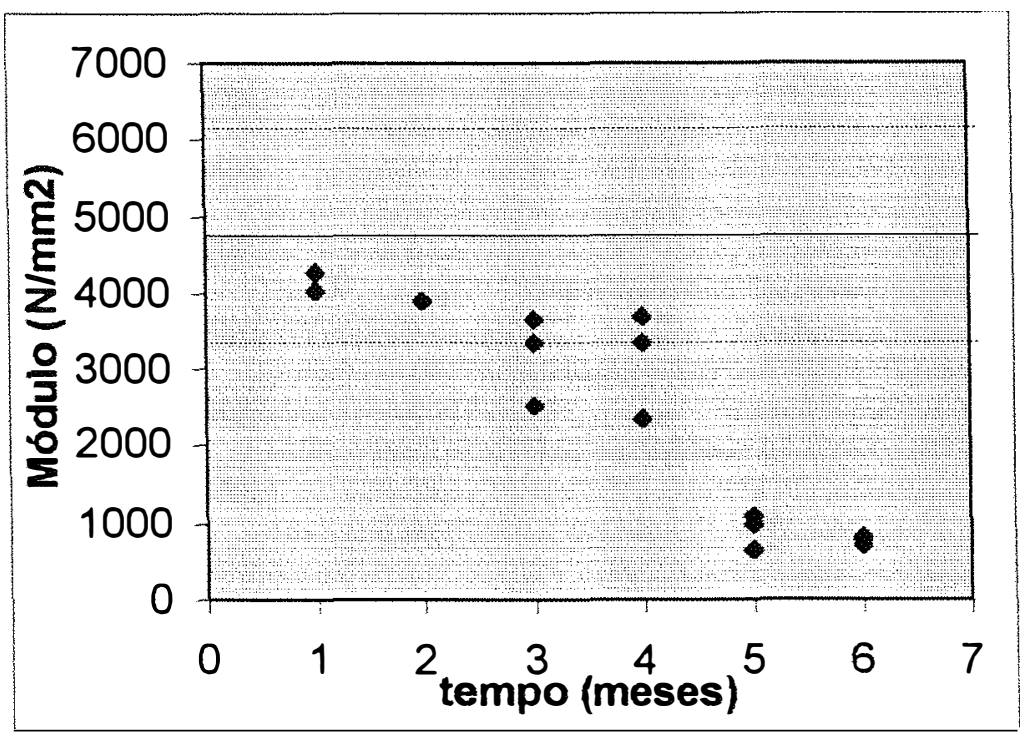

Figura 6.22 - Módulo de elasticidade na direção "Z" das amostras de leite envelhecidas no intemperismo natural. A linha contínua representa a média da amostra original e as linhas pontilhadas a dispersão $( \pm 3 \sigma)$ desta amostra

As Figuras 6.23, 6.24 e 6.25 representam graficamente os resultados da Tabela 5.27 referente a tensão de ruptura, módulo de elasticidade e alongamento na ruptura das amostras da embalagem de suco. Como dito anteriormente, a amostra com seis meses de envelhecimento foi excluída da análise no gráfico porque não é representativa deste conjunto de dados.

A perda significativa destas propriedades nesta embalagem que não apresentou perda de massa, pode ser atribuída a degradação da celulose pela radiação ultravioleta, conforme relatado na literatura.

Estas amostras, também, apresentaram significativa alteração da espessura, 0 que mostra 0 inchamento das fibras (por adsorção ou capilaridade), este fenômeno pode prejudicar a ligação entre fibras facilitando a quebra das mesmas do ensaio de resistência à tração. 


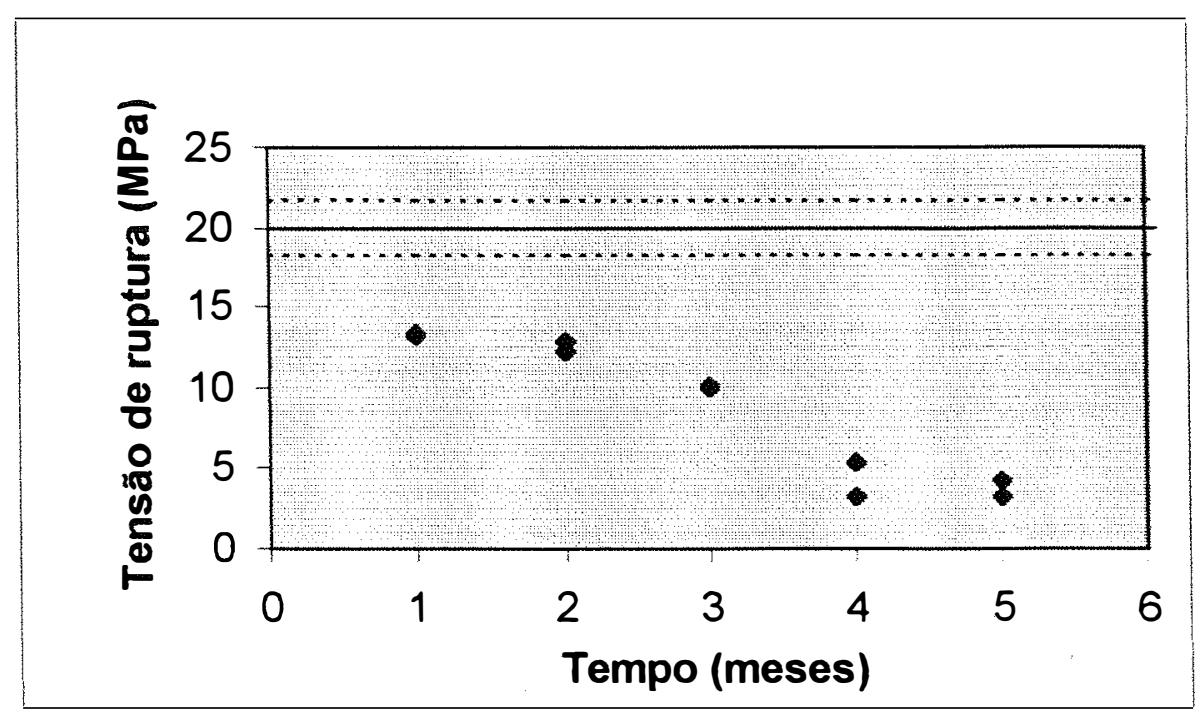

Figura 6.23- Tensão de ruptura das amostras de suco envelhecidas no intemperismo natural. A linha contínua representa a média da amostra original e as linhas pontilhadas a dispersão $( \pm 3 \sigma)$ desta amostra.

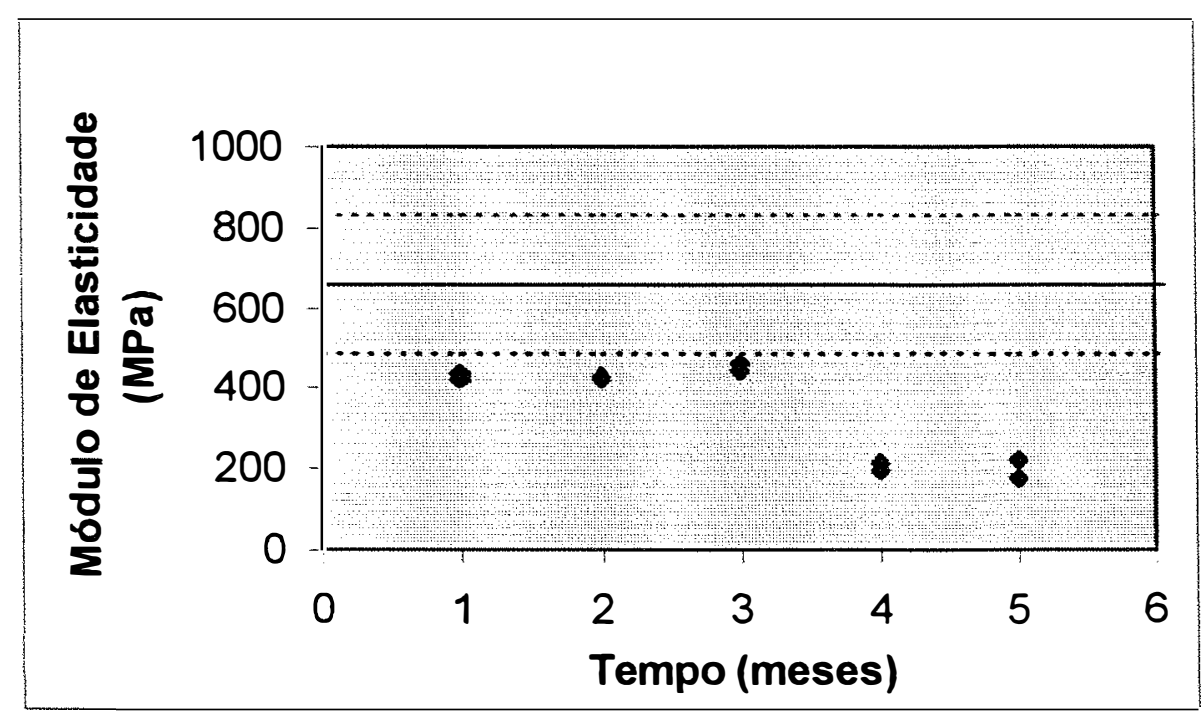

Figura 6.24 - Módulo de elasticidade das amostras de suco envelhecidas no intemperismo natural. A linha contínua representa a média da amostra original e as linhas pontilhadas a dispersão $( \pm 3 \sigma)$ desta amostra. 


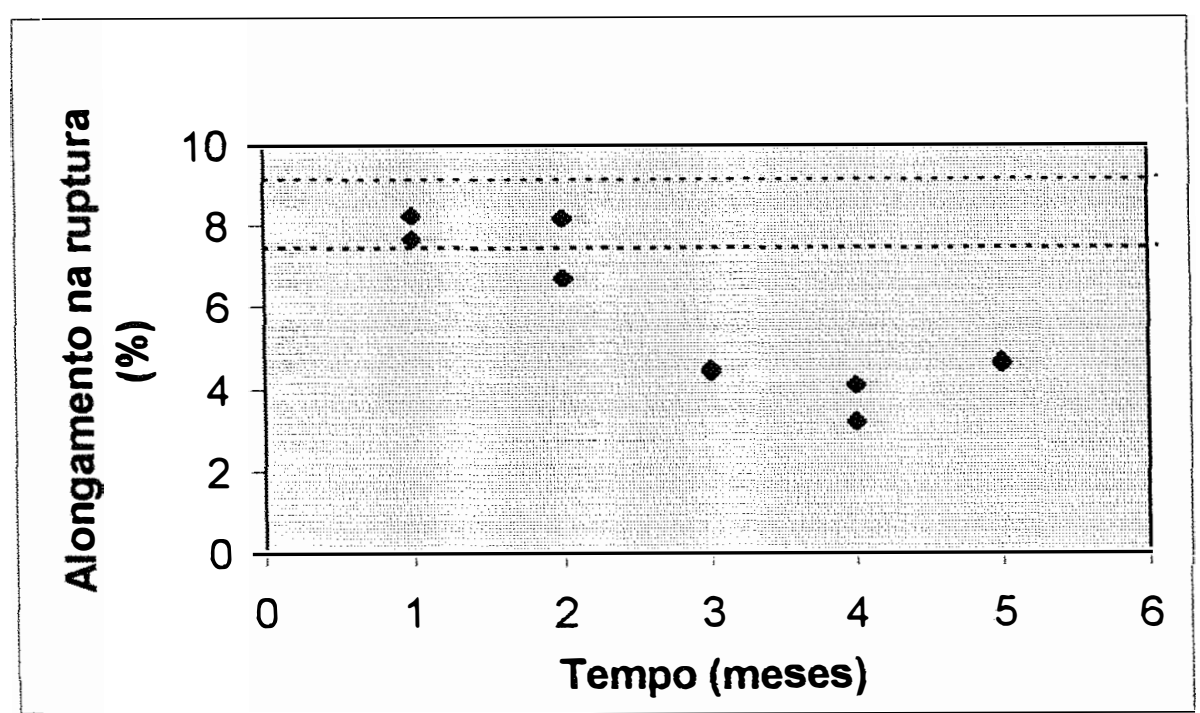

Figura 6.25 - Alongamento na ruptura das amostras de suco envelhecida no intemperismo natural. A linha contínua representa a média da amostra original e as linhas pontilhadas a dispersão $( \pm 3 \sigma)$ desta amostra

As Figuras 6.26, 6.27 e 6.28 mostram graficamente os resultados da Tabela 5.28 referente a tensão de ruptura, módulo de elasticidade e alongamento na ruptura das amostras da embalagem de leite. A tendência exponencial da amostra foi ajustada pela curva conforme equação 6.4 .

A perda significativa destas propriedades nesta embalagem, logo no primeiro mês de exposição, pode ser atribuída a degradação da celulose pela radiação ultravioleta, e a partir no quinto mês também, à perda significativa de massa, conforme visto na Figura 6.17. 


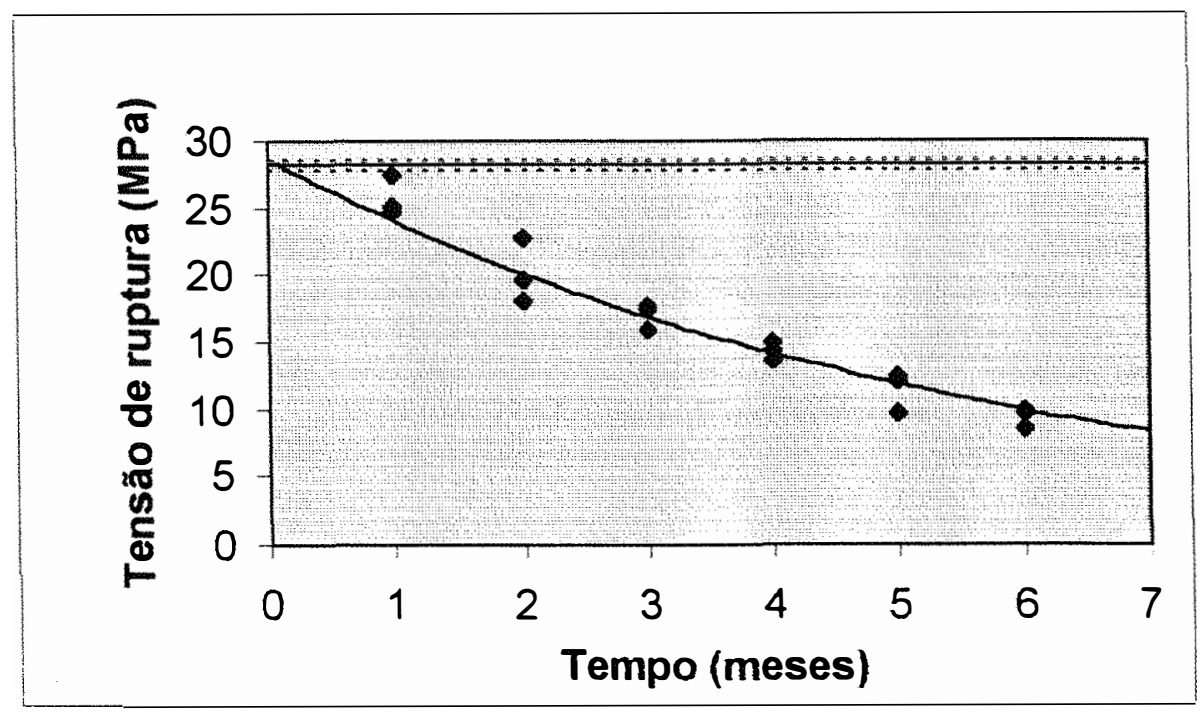

Figura 6.26 - Tensão de ruptura das amostras de leite envelhecidas no intemperismo natural. A linha reta contínua representa a média da amostra original e as linhas pontilhadas a dispersão $( \pm 3 \sigma)$ desta amostra. A linha curva contínua evidencia a tendência exponencial de degradação da amostra com o tempo.

$$
T R=28,7 \exp \{-0,176 t\}
$$

onde:

$\mathrm{TR}=$ tensão de ruptura, em $\mathrm{MPa}$

$t=$ tempo de exposição, em meses

A incerteza no coeficiente de $t$ é igual a 0,007 meses $^{-1}$ e no coeficiente TR é igual a 0,4 MPa.

A vida média pode ser estimada a partir da equação 6.4 , ou seja, é inverso do coeficiente de t. O valor encontrado de vida média foi de 5,7 meses com desvio-padrão de 0,22 mês. 


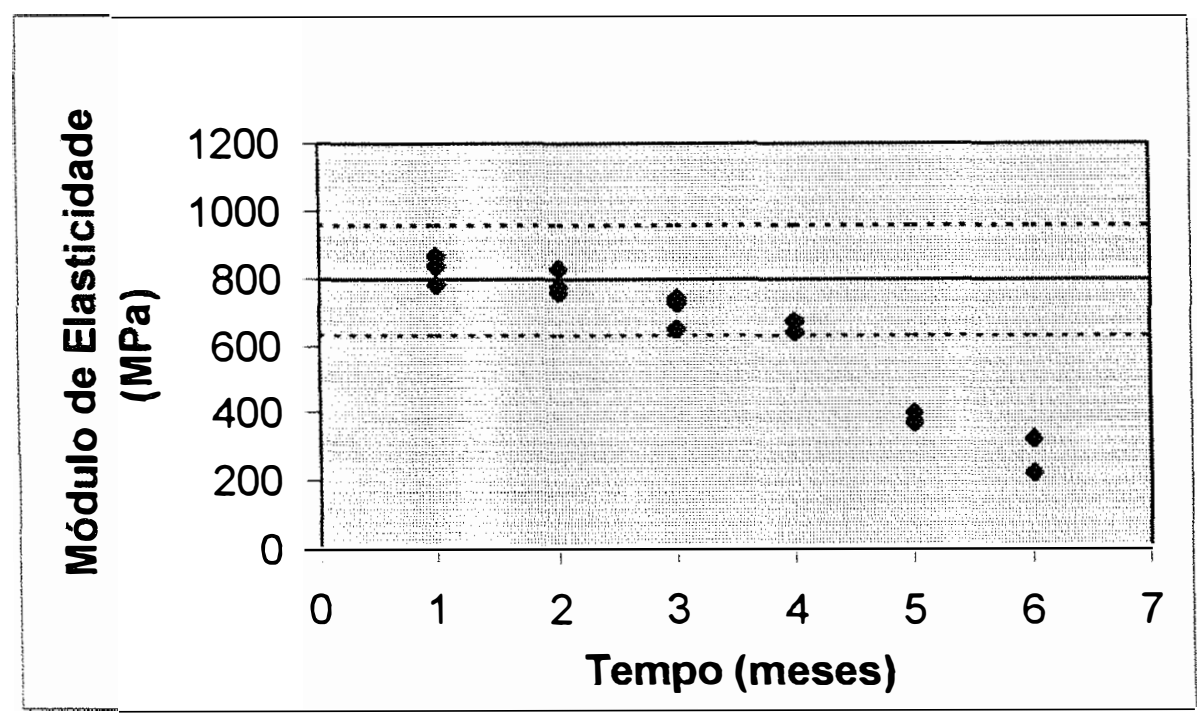

Figura 6.27 - Módulo de elasticidade das amostras de leite envelhecidas no intemperismo natural. A linha contínua representa a média da amostra original e as linhas pontilhadas a dispersão $( \pm 3 \sigma)$ desta amostra.

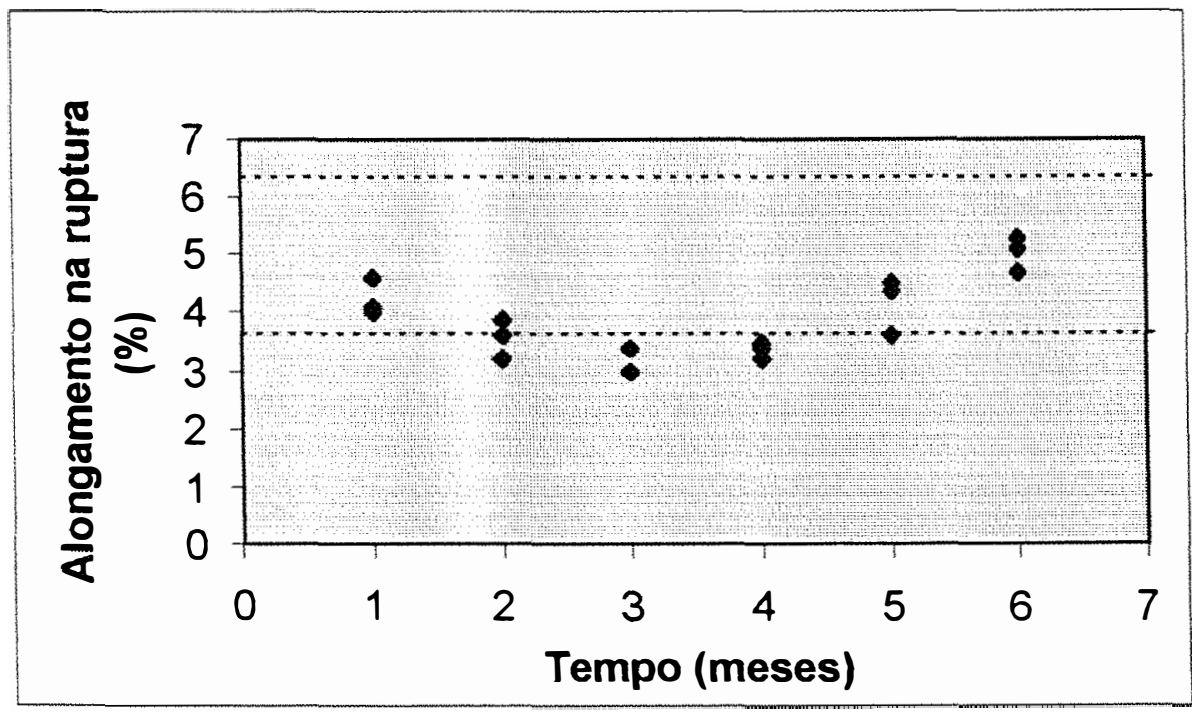

Figura 6.28 - Alongamento na ruptura das amostras de leite envelhecidas no intemperismo natural. A linha contínua representa a média da amostra original e as linhas pontilhadas a dispersão $( \pm 3 \sigma)$ desta amostra. 
As alterações na estrutura química das camadas externas polimérica de ambas as amostras conforme mostrado nas Figuras 5.12 e 5.13 do capítulo anterior, mostraram a presença de uma banda na região de 1700 $\mathrm{cm}^{-1}$, característica de um grupo carbonila e uma outra banda próxima de $1000 \mathrm{~cm}^{-1}$, característica de grupos vinil com isomeria trans. A literatura mostra que o sur gimento destes grupos indicam a degradação do polietileno (Kelen, 1983).

Para a amostra de embalagem de leite com cinco e seis meses de exposição, a degradação desta camada também foi retratada pelo significativo desaparecimento desta camada na embalagem, deixando exposto o cartão. Este fato, pode ser atribuído a ação mecânica provocada pelas chuvas e ventos, mais intensas nos períodos de dezembro a fevereiro (ver Tabela 4.1), sobre esta camada que já se encontrava fragilizada pela oxidação causada pela radiação ultravioleta, emitida pelo sol.

Não foi observado alteração da camada de alumínio da embalagem de leite neste período de exposição às intempéries. Entretanto, possivelmente ele também seria atingido pela ação das intempéries em maior tempo de exposição, porque o revestimento externo (mesmo polímero do revestimento do alumínio) foi removido.

\subsubsection{Degradabilidade por ação do calor}

Neste ensaio, é esperada alterações nas propriedades físicas e químicas das embalagens. Entretanto, será verificada se estas alterações são significativas e se colaboram com degradação das amostras. Pois, ao final, pode-se também analisar a influência do calor no ensaio de degradação no chorume, já que este foi realizado na mesma temperatura. 
Ambas as amostras não apresentaram variação significativa de massa. Os valores finais médios de gramatura das embalagens, conforme Tabela 5.29 , foram de $436 \mathrm{~g} / \mathrm{m}^{2}$, para as de suco, e $375 \mathrm{~g} / \mathrm{m}^{2}$, para as de leite. Este valores estão dentro da variabilidade admissível para estruturas originais.

O exame visual das amostras revelou que elas mantiveram 0 seu aspecto de novas, não sendo possível distinguir a olho desarmado diferenças entre as que foram submetidas ao tratamento e as embalagens originais.

As Figuras 6.29 e 6.30 representam graficamente os resultados da Tabela 5.30 referente a rigidez e módulo de elasticidade " $Z$ " das amostras de embalagem de suco. Pode-se notar que este tratamento não alterou significativamente estas propriedades nesta amostra.

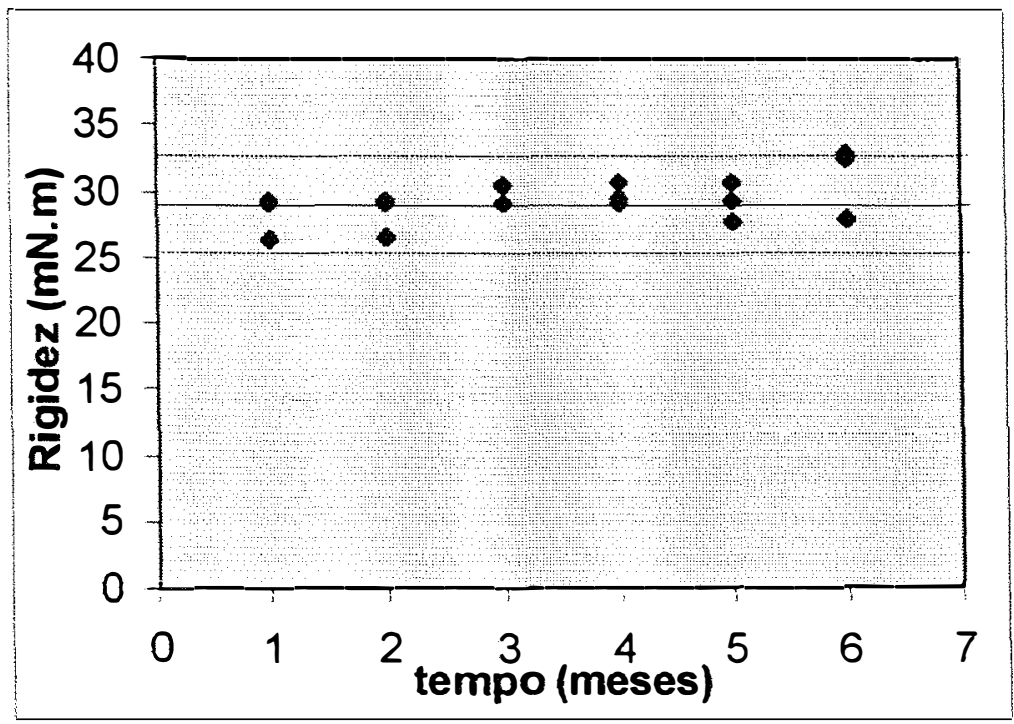

Figura 6.29 - Rigidez Lhomargy das amostras de suco envelhecidas na estufa. A linha contínua representa a média da amostra original e as linhas pontilhadas a dispersão $( \pm 3 \sigma)$ desta amostra. 


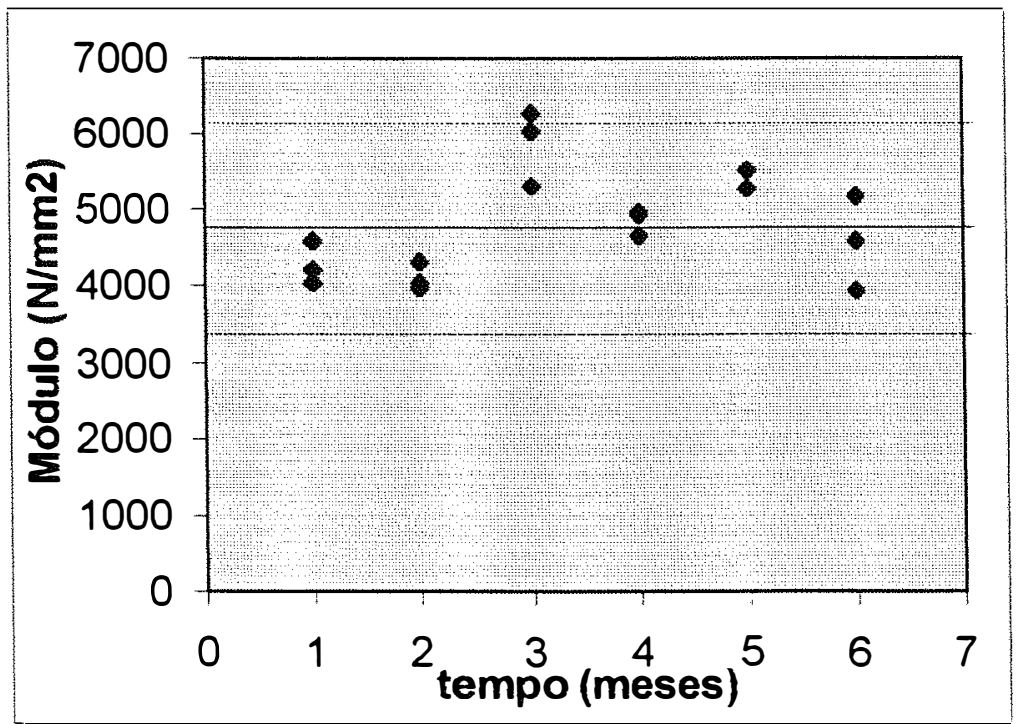

Figura 6.30 - Módulo de elasticidade na direção "Z" das amostras de suco envelhecidas na estufa. A linha contínua representa a média da amostra original e as linhas pontilhadas a dispersão $( \pm 3 \sigma)$ desta amostra

Entretanto, ocorreu uma discreta tendência de elevação dos valores de rigidez a partir de três meses de exposição. Sabe-se que os materiais plásticos (camada externa e interna da embalagem) podem perder plastificantes que resultaria no aumento de sua rigidez. As fibras que compõem o cartão perdem a água (contração das fibras e conseqüente alteração das dimensões do cartão) com tratamento térmico tornando-o mais rígido.

As Figuras 6.31 e 6.32 representam graficamente os resultados da Tabela 5.31 referente a rigidez e módulo de elasticidade das amostras de embalagem de leite. Estas Figuras mostram que rigidez destas amostras não foram significativamente afetadas pela envelhecimento na estufa. 


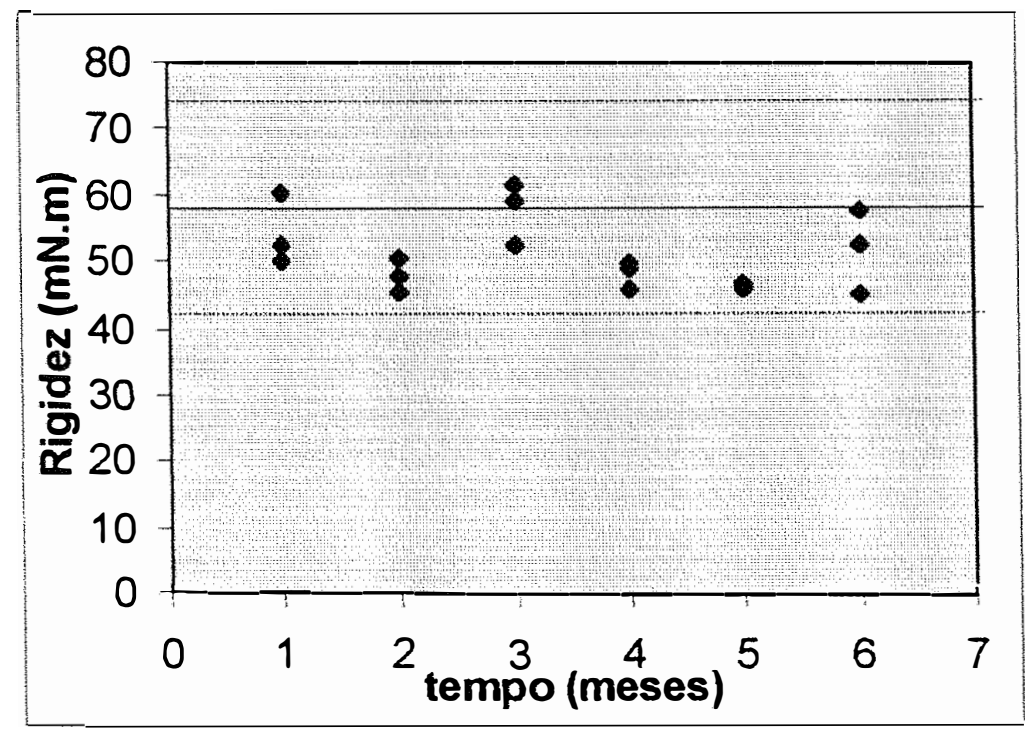

Figura 6.31 - Rigidez Lhomargy das amostras de leite envelhecidas na estufa. A linha contínua representa a média da amostra original e as linhas pontilhadas a dispersão $( \pm 3 \sigma)$ desta amostra.

As Figuras $6.33,6.34$ e 6.35 mostram graficamente os resultados da Tabela 5.33 referentes a tensão de ruptura, módulo de elasticidade e alongamento na ruptura da embalagem de leite. 


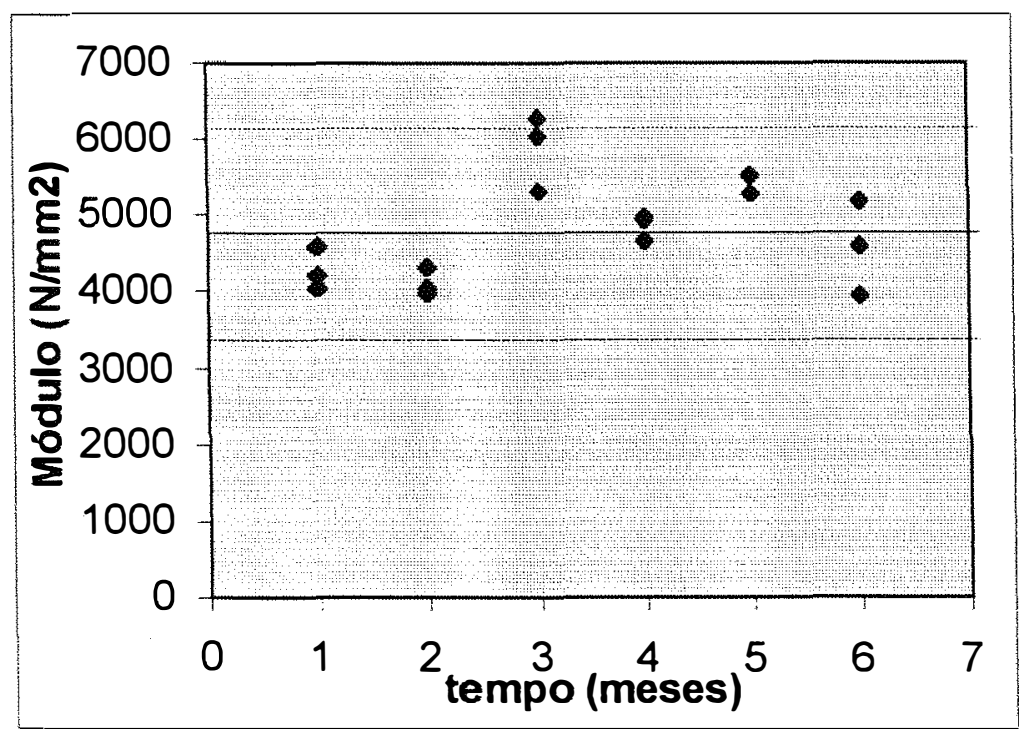

Figura 6.32 - Módulo de elasticidade na direção " $Z$ " das amostras de leite envelhecidas na estufa. A linha contínua representa a média da amostra original e as linhas pontilhadas a dispersão $( \pm 3 \sigma)$ desta amostra.

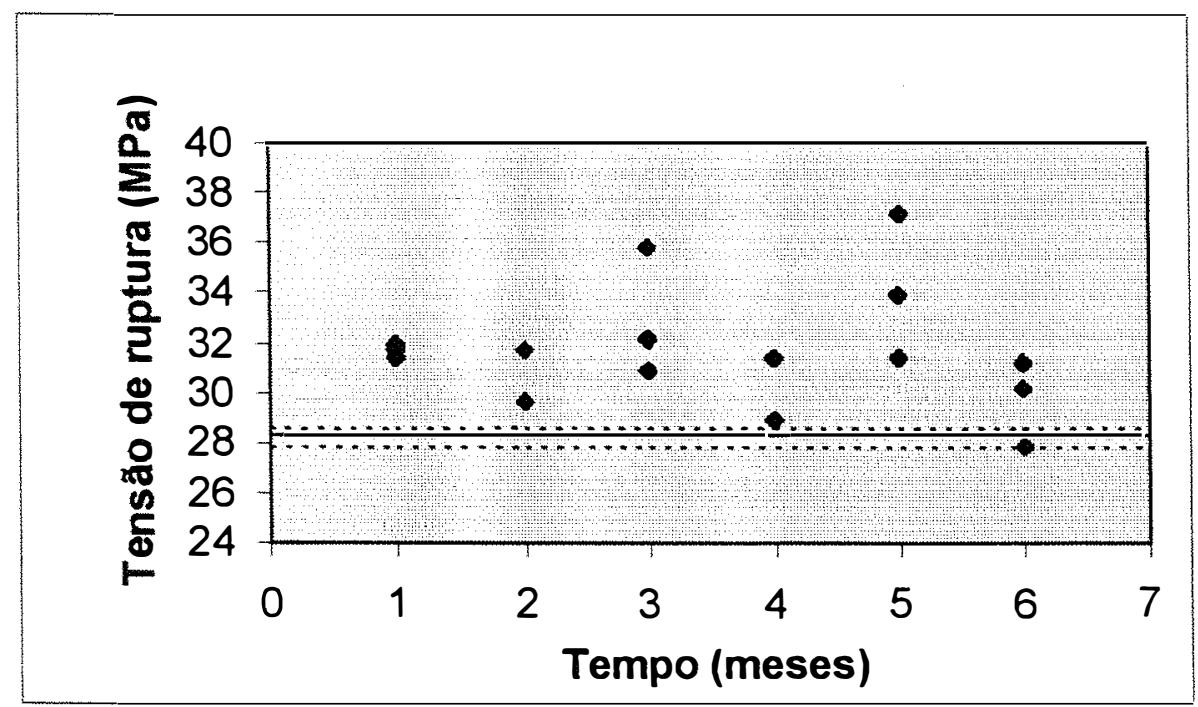

Figura 6.33 - Tensão de ruptura das amostras de leite envelhecidas na estufa. A linha contínua representa a média da amostra original e as linhas pontilhadas a dispersão $( \pm 3 \sigma)$ desta amostra. 


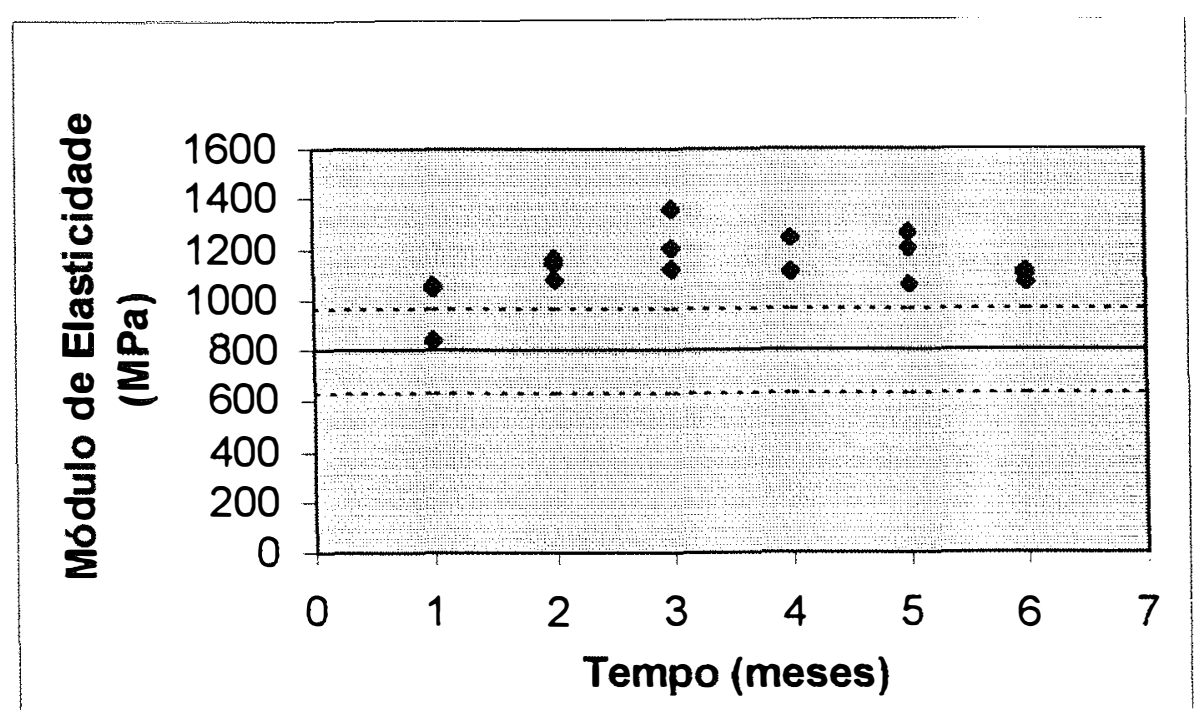

Figura 6.34 - Módulo de elasticidade das amostras de leite envelhecidas na estufa. A linha contínua representa a média da amostra original e as linhas pontilhadas a dispersão $( \pm 3 \sigma)$ desta amostra

Algumas amostras de leite envelhecidas na estufa delaminaram a camada interna de polietileno, isto pode explicar a grande dispersão dos valores de uma amostra num mesmo período. O comportamento, na tensão de ruptura e módulo em função do tempo de exposição neste tratamento, das amostras teve uma discreta melhoria. Entretanto a partir do segundo mês de envelhecimento, pode-se observar na Figura 6.35 uma discreta tendência de queda no alongamento.

O tratamento térmico pode melhorar as propriedades do papel, entretanto o objetivo deste trabalho é verificar o efeito que a temperatura pode acarretar na degradação da embalagem multicamada, bem como a possível interferência deste tratamento na degradação em chorume. 


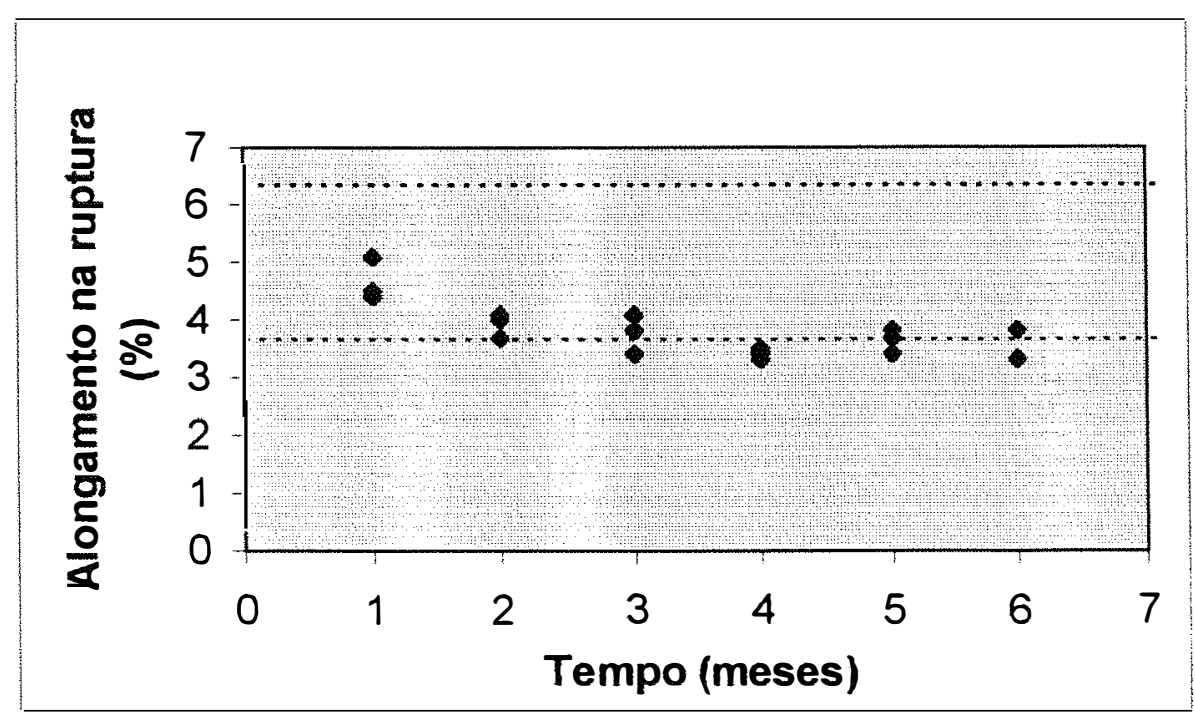

Figura 6.35 - Alongamento na ruptura das amostras de leite envelhecidas na estufa. A linha contínua representa a média da amostra original e as linhas pontilhadas a dispersão $( \pm 3 \sigma)$ desta amostra

As Figuras 6.36, 6.37 e 6.38 mostram graficamente os resultados da Tabela 5.32 referente a tensão de ruptura, módulo de elasticidade e alongamento na ruptura das amostras de embalagem de suco. Estas propriedades não foram significativamente afetadas pelo envelhecimento na estufa, mostrando que a embalagem de suco é mais estável ao calor do que a embalagem de leite. 


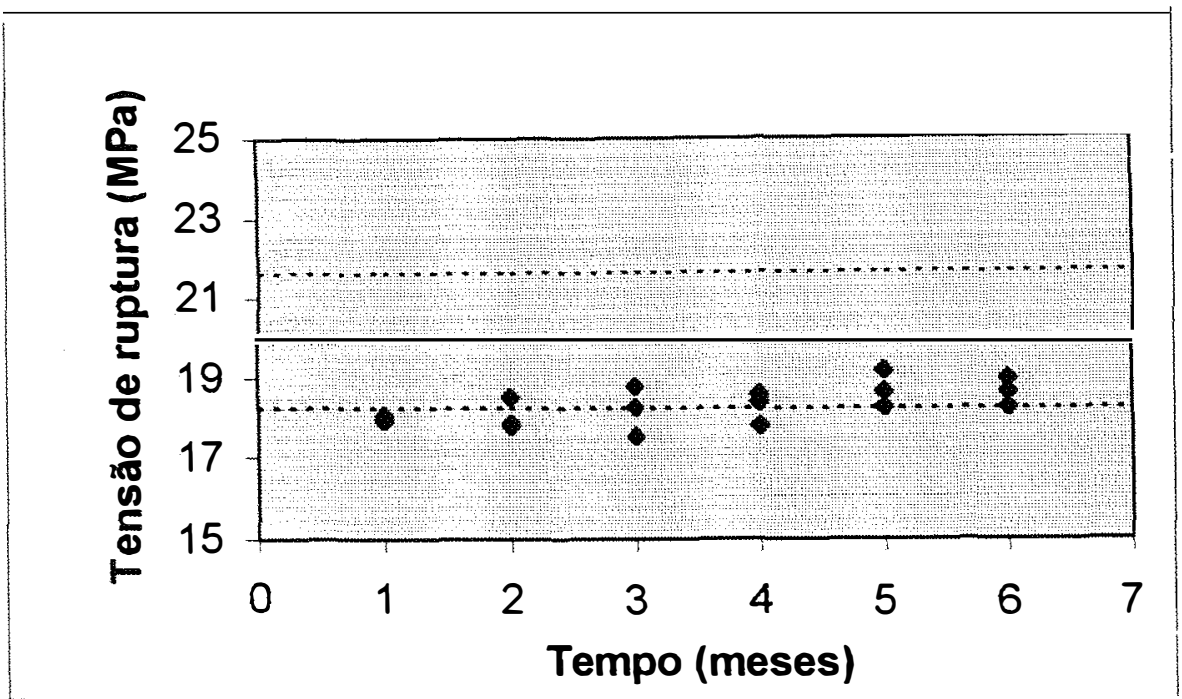

Figura 6.36 - Tensão de ruptura das amostras de suco envelhecidas na estufa. A linha contínua representa a média da amostra original e as linhas pontilhadas a dispersão $( \pm 3 \sigma)$ desta amostra.

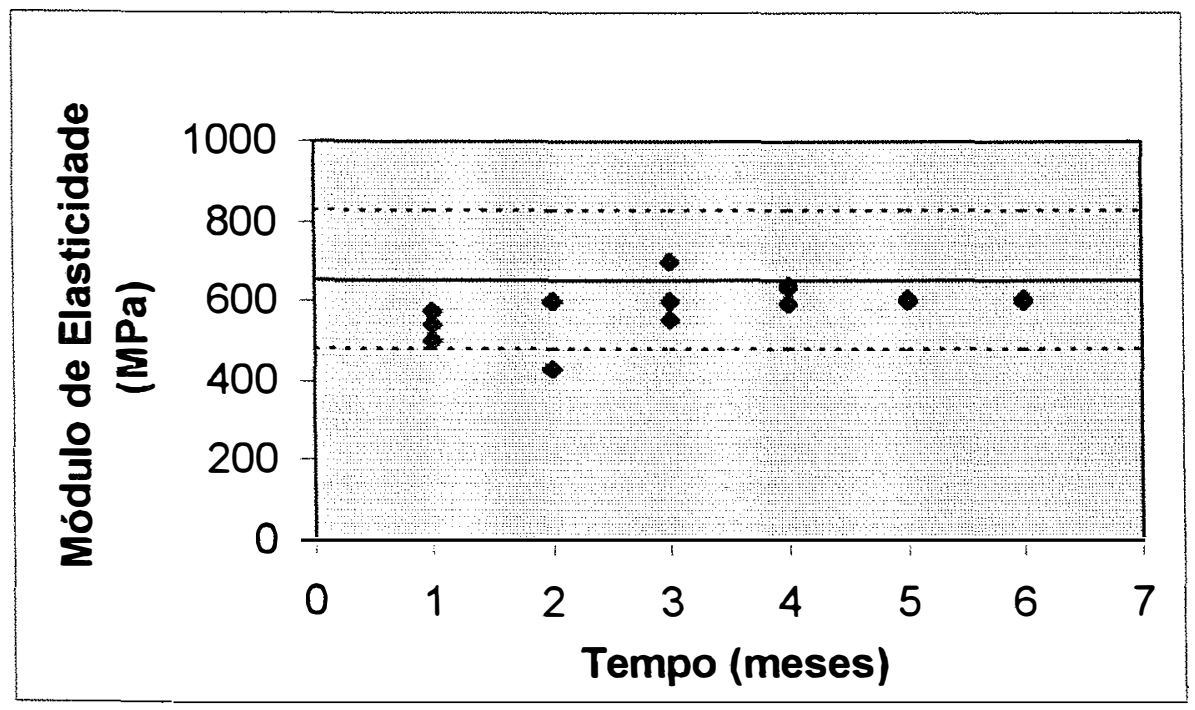

Figura 6.37 - Módulo de elasticidade das amostras de suco envelhecidas na estufa. A linha contínua representa a média da amostra original e as linhas pontilhadas a dispersão $( \pm 3 \sigma)$ desta amostra. 


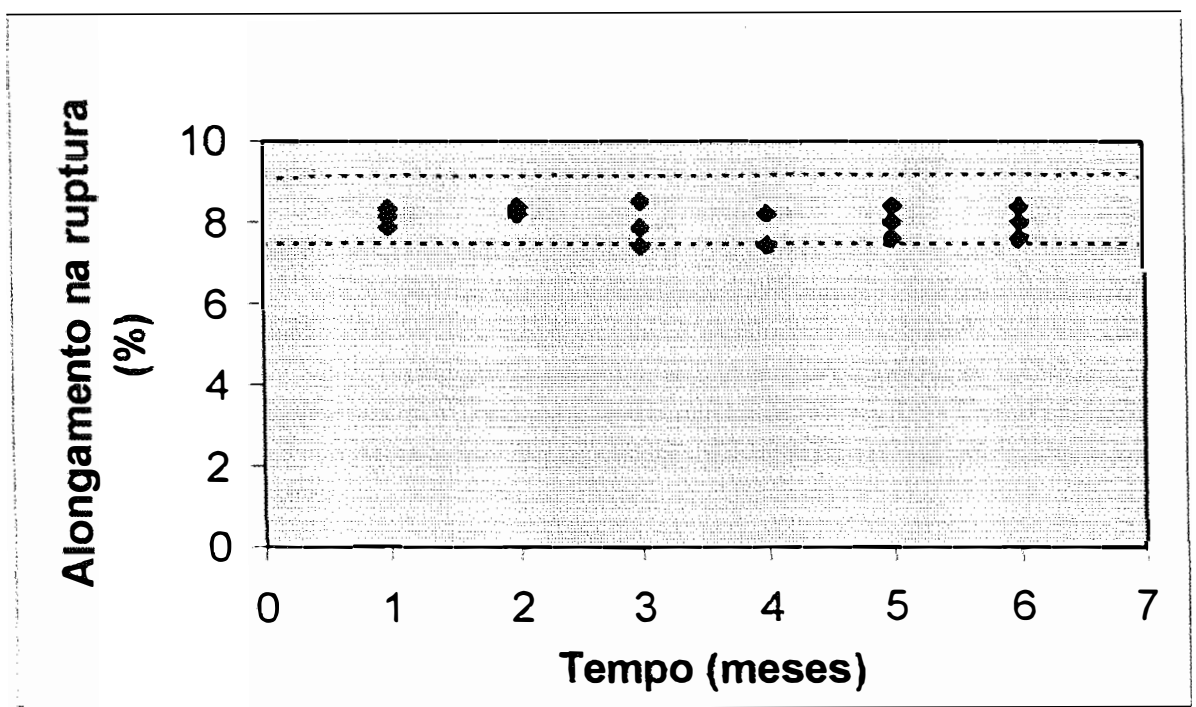

Figura 6.38 - Alongamento na ruptura das amostras de suco envelhecidas na estufa. A linha contínua representa a média da amostra original e as linhas pontilhadas a dispersão $( \pm 3 \sigma)$ desta amostra.

As camadas poliméricas de ambas as amostras mostraram, através da análise de espectrofotometria no infravermelho, bandas de absorção características de polietileno oxidado (ver Figuras 5.14, 5.15, 5.16 e 5.17 do capítulo anterior), conforme relata a literatura (Kelen,1983). Esta oxidação era esperada já que a ação do calor e oxigênio provocam o efeito ozônio que degradam mais rapidamente os plásticos (Briston \& Katan, 1974).

\subsection{Análise Integrada dos Ensaios de Degradabilidade}

A Tabela 6.1 mostra, com base nos resultados de tensão de ruptura ou rigidez Lhomargy, os valores de vida média que foram possíveis de serem obtidos nos ensaios de degradação realizados e as porcentagens de perda de resistência e massa ao final do último período de exposição de ambas as embalagens. A perda de massa das embalagens também está retratada nesta tabela através dos resultados da análise visual e das medidas realizadas. 
Tabela 6.1 - Degradação das embalagens multicamadas com base na perda de resistência e massa

\begin{tabular}{|c|c|c|c|c|c|c|c|c|}
\hline & \multicolumn{2}{|c|}{ chorume } & \multicolumn{2}{|c|}{ intempéries } & \multicolumn{2}{|c|}{ u.v. } & \multicolumn{2}{|c|}{ estufa } \\
\hline & leite & suco & leite & suco & leite & suco & leite & suco \\
\hline Vida média - tração & - & $\begin{array}{c}6,1 \\
\text { meses }\end{array}$ & $\begin{array}{c}5,7 \\
\text { meses }\end{array}$ & - & $441 \mathrm{~h}$ & - & - & - \\
\hline Vida média - rigidez & - & - & - & $\begin{array}{c}4,3 \\
\text { meses }\end{array}$ & - & - & - & - \\
\hline $\begin{array}{l}\text { Perda de resistência à } \\
\text { tração após } 6 \text { meses (\%) }\end{array}$ & 67 & 52 & 65 & $80^{*}$ & 19 & 11 & $-8,9$ & 7,5 \\
\hline $\begin{array}{l}\text { Perda de massa após } 6 \\
\text { meses }(\%)\end{array}$ & 49 & $\begin{array}{l}\text { Houve } \\
\text { ganho }\end{array}$ & 21 & 0 & 0 & 0 & 0 & 0 \\
\hline $\begin{array}{l}\text { Perda de material da } \\
\text { embalagem por análise } \\
\text { visual }\end{array}$ & $\operatorname{sim}$ & $\operatorname{sim}$ & $\operatorname{sim}$ & $\operatorname{sim}^{\star \star}$ & não & não & não & não \\
\hline
\end{tabular}

* calculada com a amostra com cinco meses de exposição.

** alteração significativa da cor (perda de pigmentação) e presença de trincas da camada polimérica deixando expostas as fibras do cartão que pela chuva e ventos podem ter sido retiradas.

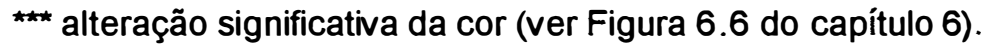

A perda de resistência à tração em função do tempo para cada ensaio está mostrada nas Figuras $6.39,6.40,6.41$ e 6.42. Estas figuras possibilitam avaliar comparativamente e individualmente em que períodos a degradação é mais acentuada.

Na Figura 6.39 é evidente que a embalagem de leite apresenta uma perda de resistência à tração maior e antes se comparada com a embalagem de suco. Nota-se que logo no primeiro mês a amostra de leite perdeu cerca de $60 \%$ enquanto que a amostra de suco perdeu $40 \%$, entretanto ao final de seis meses ambas estão quase equivalentes. 


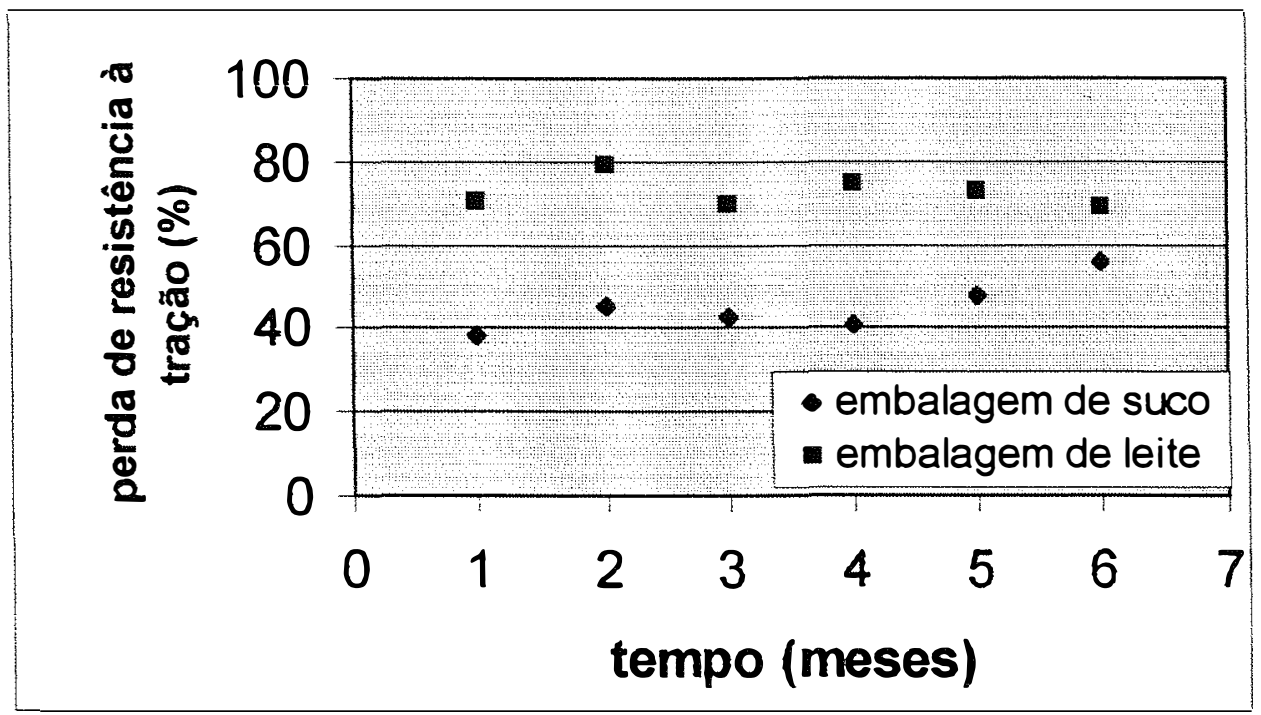

Figura 6.39 - Perda da resistência à tração em função do tempo de imersão em chorume.

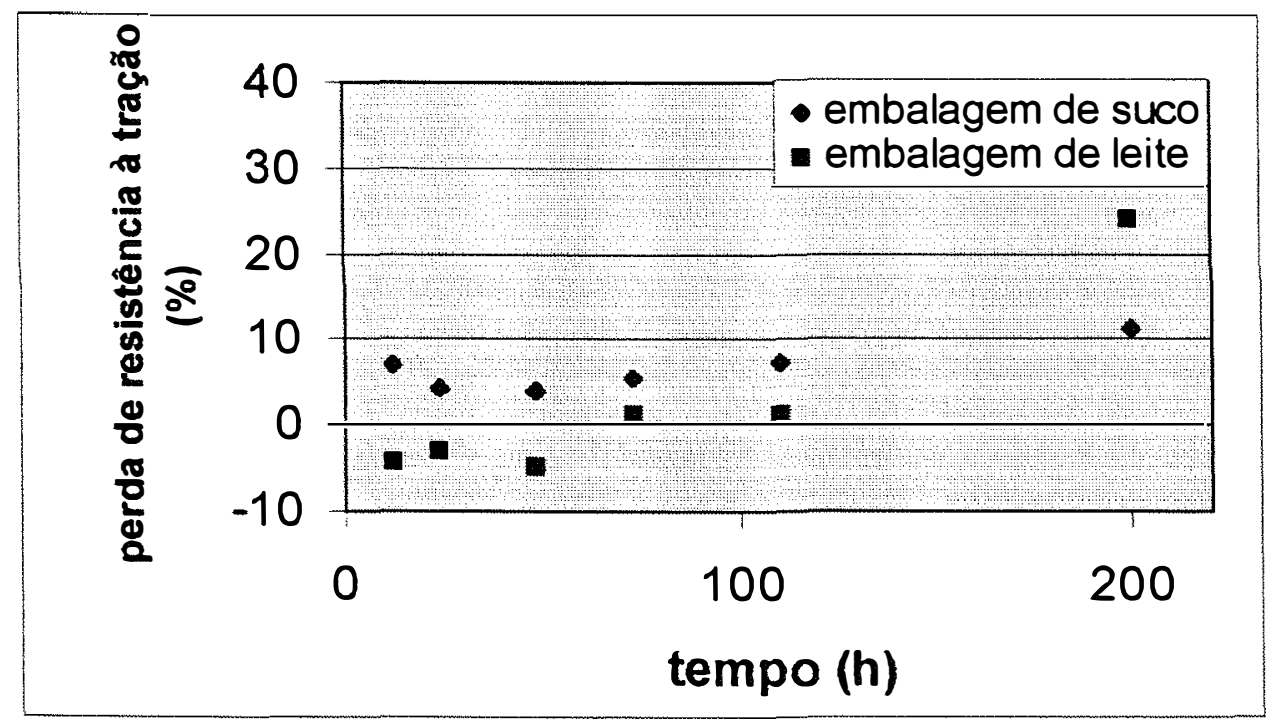

Figura 6.40 - Perda da resistência à tração em função do tempo de exposição à radiação ultravioleta 
A amostra de embalagem de suco é inicialmente mais afetada pela radiação ultravioleta, conforme mostrado na Figura 6.40. Entretanto após $200 \mathrm{~h}$ de exposição, há uma inversão de posições a amostra de suco perdeu cerca de $10 \%$ da resistência, enquanto que a amostra de leite perdeu cerca de $25 \%$ da resistência à tração. Observa-se que até cerca de $50 \mathrm{~h}$ de exposição ambas tiveram uma tendência de melhora da resistência à tração, sendo mais significativa para a embalagem de leite.

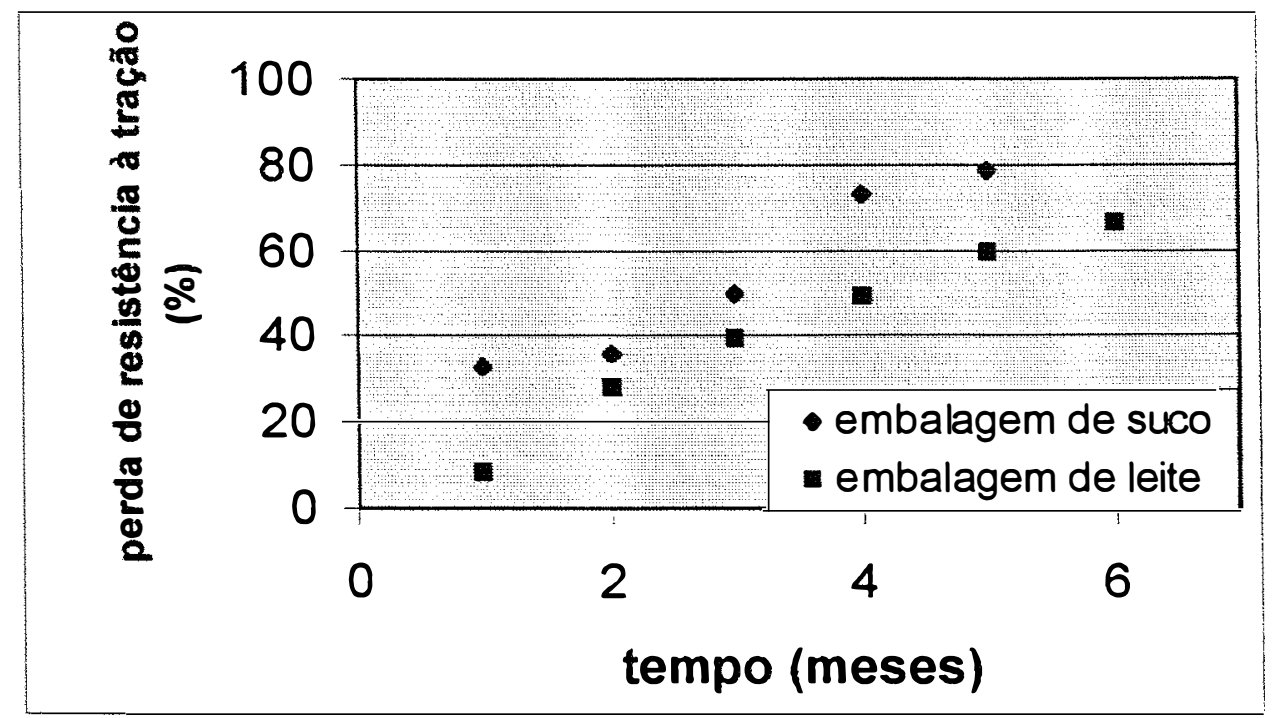

Figura 6.41 - Perda da resistência à tração em função do tempo de exposição às intempéries.

A Figura 6.41 mostra que ambas as amostras apresentaram uma tendência linear de perda de resistência à tração por ação das intempéries. Somente a partir do quarto mês de exposição a amostra de suco perdeu significativamente mais que a de leite. Comparativamente, no quinto mês a amostra de leite perdeu $60 \%$ da sua resistência à tração e a de suco perdeu $80 \%$. 
A Figura 6.42 mostra que a degradação por calor ocorreu somente na amostra de suco, com a perda aproximada de $10 \%$ de resistência à tração em relação aos vaiores originais. A amostra de leite teve uma discreta melhora nas propriedades de resistência à tração associada ao cartão que pode ter este comportamento quando é submetido a um tratamento térmico, ou seja, ao perder a água e se torna mais rígido (ver item 6.2.4 do capítulo 6).

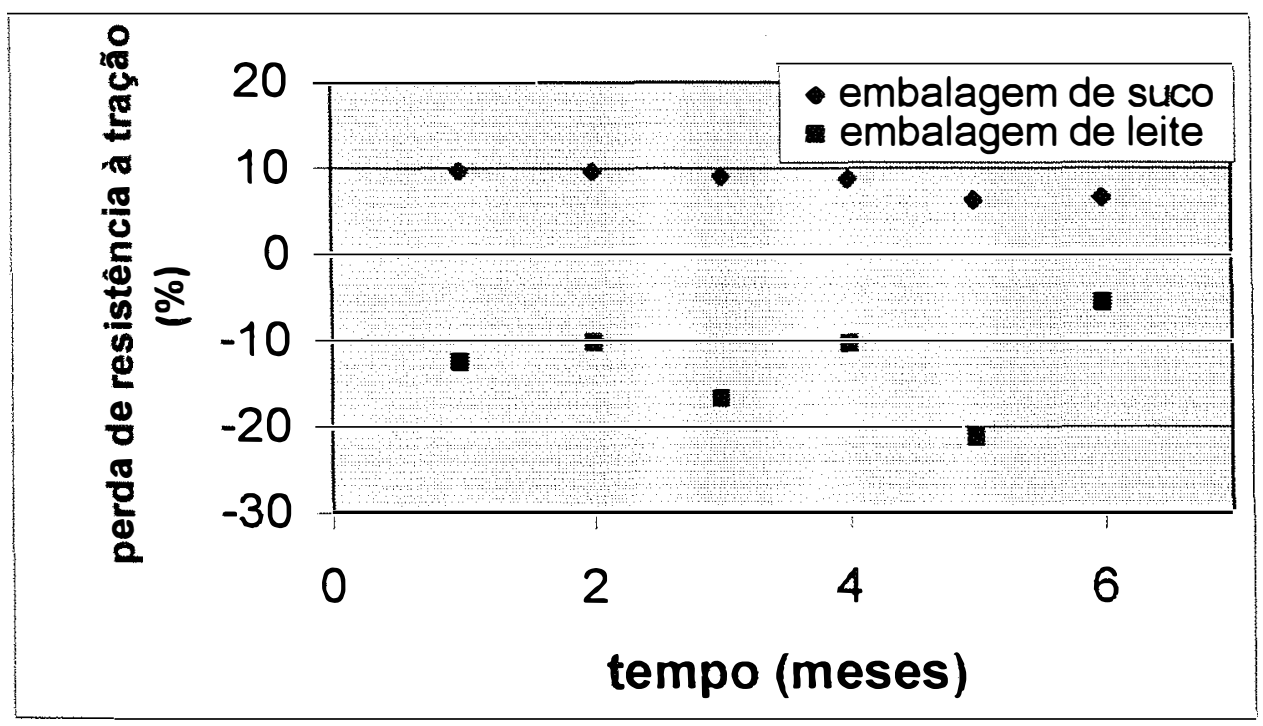

6.42 - Perda da resistência à tração em função do tempo de exposição ao calor

Alterações na estrutura química das camadas de polietileno ocorreram em todos os ensaios de degradabilidade. Para analisar melhor a degradação ocorrida no ensaio de imersão no chorume, pode-se, inicialmente, isolar o efeito da temperatura (ensaio de exposição ao calor em estufa).

As alterações da estrutura da cadeia polimérica que evidenciam um início de processo de degradação do polietileno, estão associadas a uma termooxidação do polímero. As mesmas bandas de absorção foram observadas nas amostras submetidas ao tratamento só com o calor em estufa (item 5.2.4) e as imersas no chorume (item 5.2.1). Das Figuras 5.6, 5.8, 5.14 e 5.15 (reproduzidas nas Figuras 6.43 a 6.46), nota-se que as intensidades das 
bandas características de degradação do polímero foram muito maiores nos espécimes que ficaram imersos no chorume que aos colocados na estufa. Pode-se, portanto, concluir que também ocorreram outras reaçőes durante a imersão no chorume, provavelmente uma oxidação provocada pelos peróxidos autoxidantes presentes no chorume, conforme Griffin (1976) observou em suas pesquisas.

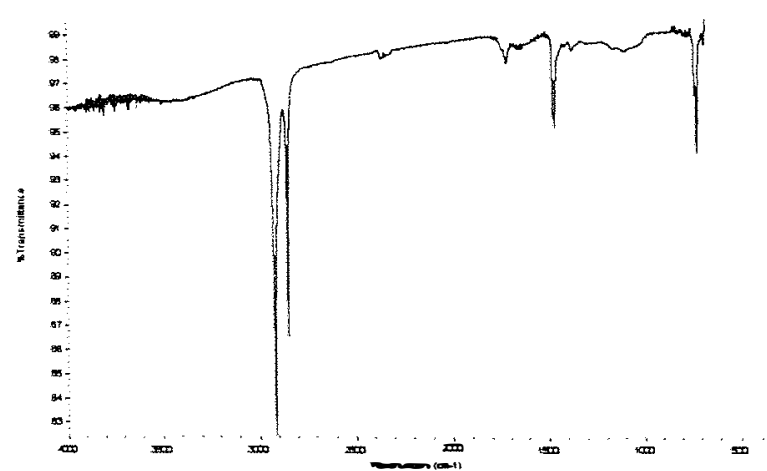

Figura 6.43 - Camada externa da amostra de embalagem de leite após seis meses de envelhecimento na estufa - polietileno oxidado

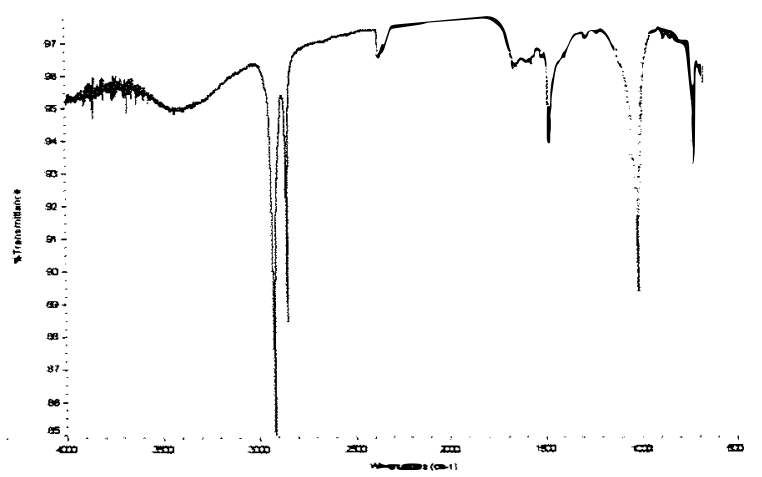

Figura 6.44 - Camada externa da amostra de embalagem de leite após seis meses de imersão em chorume polietileno oxidado.

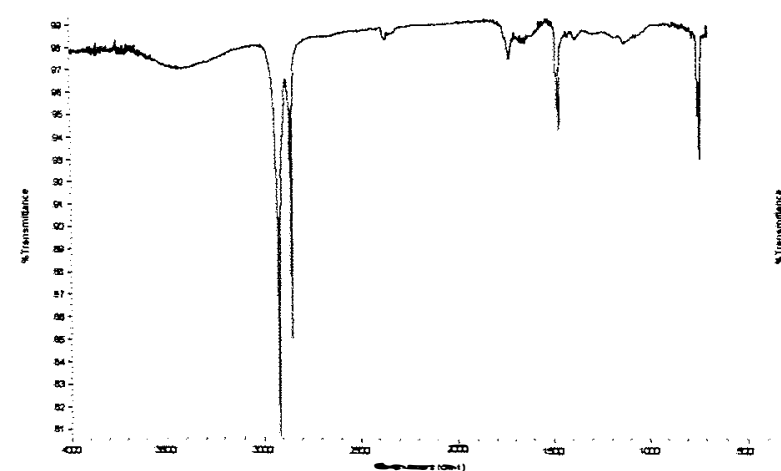

Figura 6.45 - Camada externa da amostra de embalagem de suco após seis meses de envelhecimento na estufa - polietileno oxidado

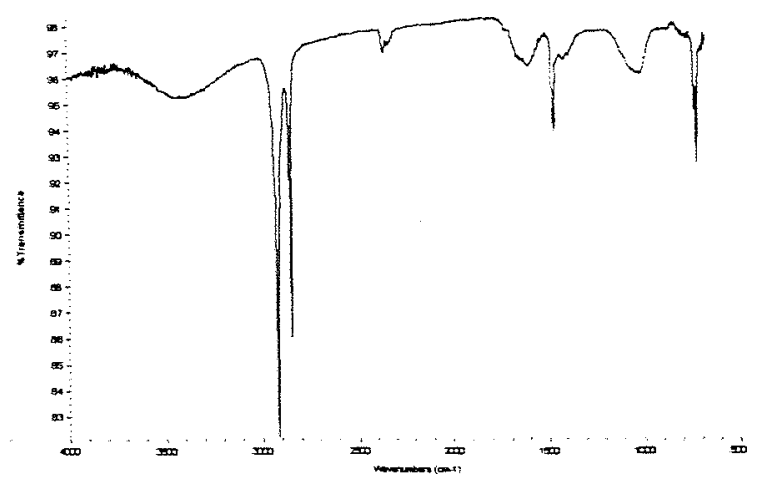

Figura 6.46 - Camada externa da amostra de embalagem de suco após seis meses de imersão no chorume polietileno oxidado. 
A degradação ocorrida nas camadas externas das embalagens no ensaio de exposição à radiação ultravioleta foi menos intensa do que a degradação pelas intempéries, conforme mostram comparativamente as Figuras 6.47 e 6.48; e as 6.49 e 6.50 (reproduzidas das Figuras 5.10, 5.11, 5.12 e 5.13). Nota-se, no espectro obtido da camada da embalagem de suco exposta à radiação ultravioleta, a presença de uma banda na região de $1700 \mathrm{~cm}^{-1}$, característica de um grupo carbonila. E nos espectros obtidos das camadas expostas ao intemperismo natural, além da banda em $1700 \mathrm{~cm}^{-1}$, uma outra banda aparece próxima de $1000 \mathrm{~cm}^{-1}$, característica de grupos vinil com isomeria trans. A literatura mostra que o surgimento destes grupos indicam a degradação do polietileno (Kelen, 1983).

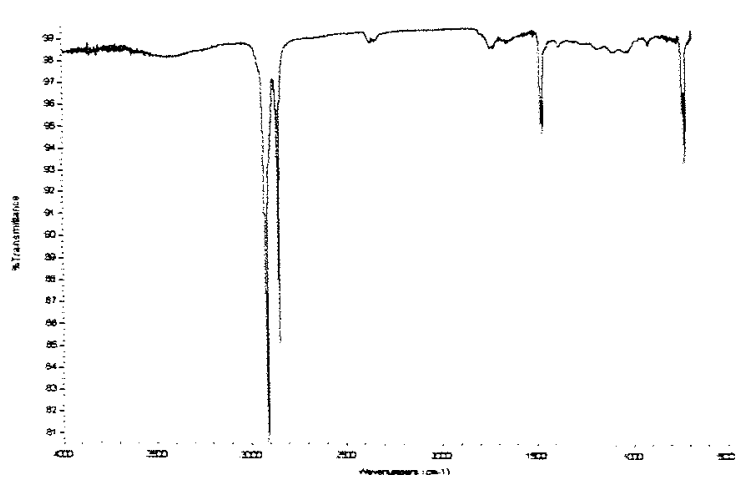

Figura 6.47 - Camada externa de leite após 200h de u.v.

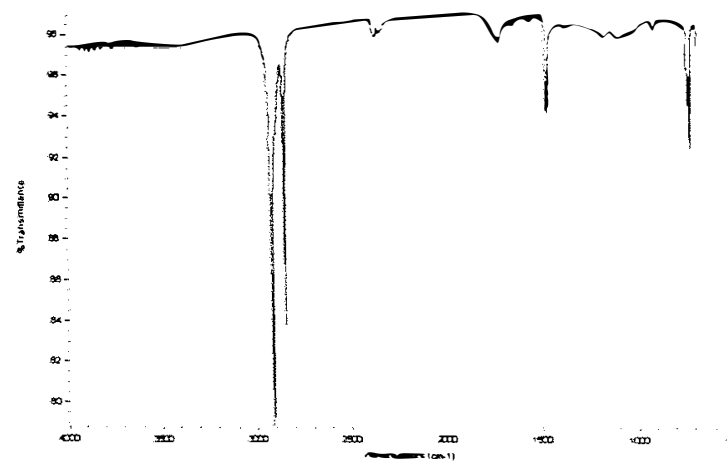

Figura 6.49 - Camada externa de suco após 200 horas de u.v.

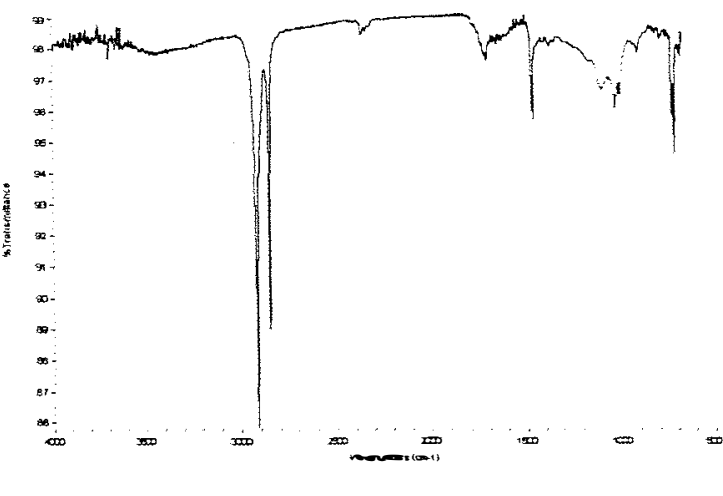

Figura 6.48 - Camada externa de leite após seis meses de intemperismo natural.

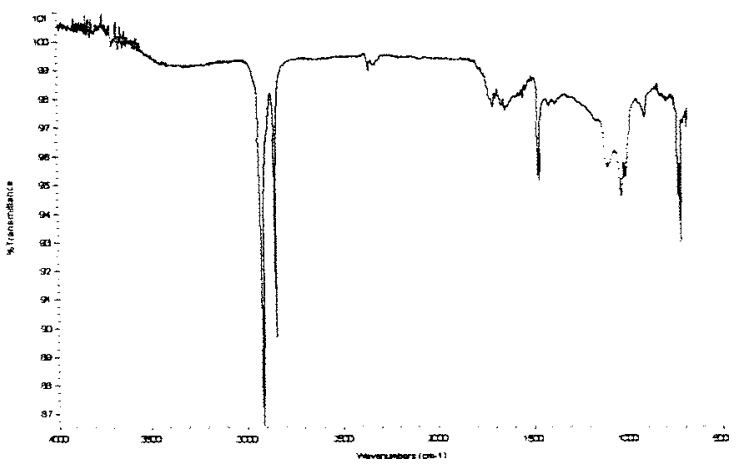

Figura 6.50 - Camada externa de suco após cinco meses de intemperismo natural. 
Estas alterações estão associadas a uma fotooxidação e termooxidação do polímero, uma vez que também foram observadas nas amostras submetidas ao tratamento só com a radiação u.v. e condensação à $60^{\circ} \mathrm{C}$. Entretanto, como as intensidades daquelas bandas características de degradação do polímero foram muito maiores nos espécimes que ficaram expostos às intempéries, pode-se concluir que também ocorreram outras reações, provavelmente a quebra da cadeia polimérica ou oxidação provocada pelos microorganismos, oxigênio, radiação e água, já que os efeitos destas entidades em conjunto é conhecido como intemperismo, conforme relatam Briston \& Katan (1974). 


\section{CONCLUSÕES}

É consenso que para o tratamento do resíduo sólido gerado pelas embalagens deve seguir a ordem: redução na fonte, reutilização, reciclagem, incineração com recuperação de energia e por fim 0 aterro sanitário.

A alternativa de reciclagem das embalagens é a mais difundida entre a sociedade como um todo. No entanto, para que a embalagem seja submetida aos processos de reciclagem, geralmente, é necessário que outras etapas ou processos tenham sido aplicados anteriormente a esta o que incorre em maiores custos e danos secundários ao meio ambiente (logística de descarte).

Está ocorrendo um crescente impacto negativo sobre 0 ambiente gerado pelo descarte de embalagens feitas com diferentes materiais combinados e com alta resistência a úmido. As propostas de solução, sejam elas através da reciclagem ou da incineração, estão ainda em uma fase piloto ou insipiente. A degradação anaeróbica em aterros sanitários é relativamente lenta, da ordem de anos.

No Brasil, aproximadamente $75 \%$ da disposição do resíduo sólido é em lixões. Portanto, a digestão dos resíduos em grande parte é aeróbica. 
Uma vida média mais curta em condições aeróbicas ou anaeróbicas de degradação e uma vida de prateleira mais longa ao produto são aspectos difíceis de convergirem em uma embalagem. Enquanto, um exige a aplicação de materiais de barreira cada vez mais eficientes para a conservação do produto, o outro requer que os componentes sejam mais suscetíveis à ação das intempéries e/ou ao ataque microbiológico e que se degradem facilmente.

Neste trabalho aplicaram-se metodologias que buscavam simular as condições de degradação aeróbicas e anaeróbicas encontradas nas diversas formas de disposição do resíduo sólido para dois tipos de embalagens multicamadas (compósito). Dessa forma, avaliou-se a metodologia empregada e comparou-se a suscetibilidade destes dois tipos se degradarem, bem como as possiveis correlações das suas distintas características com os mecanismos de degradação ocorridos.

Para simular algumas das condições encontradas nos lixões, adaptou-se uma metodologia de ensaio de exposição às intempéries que mostrou de forma comparativa, a facilidade de materiais compósitos se degradarem no ambiente. Como tentativa de avaliar esta metodologia com uma possivel correspondência de um ensaio acelerado, optou-se pela exposição das amostras numa câmara com ciclos alternados de radiação ultravioleta e condensação de água em temperatura controlada.

Para avaliar a degradabilidade das embalagens em aterro sanitário adotou-se como critério a condição mais crítica, através da imersão das embalagens no chorume na temperatura de $50^{\circ} \mathrm{C}$. Paralelamente, isolou-se - efeito do calor na degradação por exposição das amostras na mesma 
temperatura e submetendo-se as mesmas determinações das amostras imersas no chorume.

O método de degradação por intempéries natural é conhecido na indústria automobilística como um método que possibilita avaliar comparativamente tratamentos contra corrosão em peças metálicas. Neste estudo de embalagens, este ensaio mostrou-se adequado pois foi sensível o suficiente para mostrar a diferença entre as amostras e dentro da mesma amostra, a intensidade de degradação em função do tempo. Entretanto, assim como ocorre para as peças metálicas, a reprodutibilidade é prejudicada pois as condições climáticas influenciam fortemente nos resultados e não são controláveis.

Quanto ao ensaio de envelhecimento acelerado em câmara de radiação ultravioleta, sabe-se que este não corresponde integralmente ao intemperismo natural. Entretanto, com a sua aplicação foi possível observar através das perdas de resistência à tração das embalagens de leite que houve uma correspondência entre a exposição de um mês destas embalagens no intemperismo e o período de exposição de 200 horas em ultravioleta.

Isto indica que este método, embora possa ser melhorado, é bom para ser usado nas avaliações comparativas entre materiais que serão expostos às intempéries.

A metodologia criada para simular as condições críticas do aterro mostrou sensibilidade para distinguir as diferenças de suscetibilidade quanto à degradação das amostras, principalmente quanto a velocidade de degradação de cada uma. O método também propiciou a obtenção de dados coerentes no decorrer dos ensaios de acompanhamento, pois a degradação foi 
crescente com o aumento do tempo de exposição. A escala de tempo entre os ensaios de acompanhamento convém que seja adaptada de acordo com o material a ser ensaiado, isto para não acontecer aquilo que ocorreu com as embalagens de leite, nas quais, em menos de um mês perdeu $60 \%$ de sua resistência, como mostrado no gráfico da Figura 6.3 , e inviabilizou a determinação do decaimento da resistência.

Os resultados mostraram, principalmente no caso da imersão no chorume, uma forte indicação de que a amostra altera o meio de ensaio, o próprio com o decorrer do tempo de ensaio. Assim, recomënda-se que ao se realizar ensaios comparativos entre amostras, estes sejam feitos com o mesmo chorume, mas aplicado em cubas separadas.

Observou-se também que a reprodutilibidade do ensaio de imersão no chorume é prejudicada pela variação de suas próprias características, entretanto a análise, prévia e posterior ao ensaio, do chorume possibilitam que se consiga mais algumas correlações com a degradação das amostras.

A Tabela 6.1, mostrada no item 6.3 do capítulo 6, apresentou os resultados de perda resistência mecânica para os diversos ensaios. Estes resultados mostram para as embalagens de leite que as perdas de resistência em ambiente crítico de aterro e em intempéries, não apresentaram diferença significativa, sendo ambas da ordem de $65 \%$. Ao contrário, para a embalagem de suco, a perda em ambiente crítico de aterro foi de $52 \%$, significativamente inferior quando em relação ao intemperismo natural, que mostrou uma perda de $80 \%$. 
Das embalagens estudadas neste trabalho, as diferenças de comportamento que apresentam seus componentes, propriedades de absorção, propriedades de resistência mecânica e química interferem na degradabilidade inicial quando se faz o ensaio por imersão no chorume. Já o comportamento geral de perda de resistência mecânica até o final de seis meses não sofre esta influência, ou seja, foi ocorrendo até atingir cerca de $60 \%$ de perda de resistência à tração, entretanto os valores finais foram os mesmos.

Isto não ocorreu para a degradabilidade das amostras por ação das intempéries e ultravioleta. Ao final de cinco meses de exposição às intempéries a perda de resistência à tração das amostras foi diferente, pois a perda para a amostra das embalagens de leite foi de $60 \%$ de sua resistência em relação a tração original, enquanto que a de suco perdeu $80 \%$. No caso da exposição à radiação ultravioleta, ao final do ensaio, a perda desta propriedade foi de $25 \%$ para a embalagem de leite e para a de suco, de $10 \%$.

O comportamento da perda de massa é diferente para ambas as embalagens e para os diversos tipos de ensaios de degradação.

A degradação que se espera é a completa interação com o meio ambiente, ou seja, que a embalagem se desintegre e o ambiente tenha capacidade de assimilar o seu resíduo de forma a não causar dano. Neste sentido, a embalagem de leite degradou-se mais que a de suco. Em seis meses, a perda de massa da amostra de leite foi de $49 \%$ de sua massa inicial no ensaio de degradação por imersão no chorume e de $21 \%$ em exposição às intempéries, enquanto que a amostra de embalagem de suco apresentou ganho de massa no chorume e não se alterou quando exposta às intempéries no mesmo período. No entanto, um exame visual da embalagem de suco após imersão no chorume poderia induzir a uma conclusão equivocada, pois a olho 
desarmado foi mais perceptível a perda de material na camada celulósica nesta amostra (Foto 15 do item 6.2.1 de capítulo 6).

Os componentes das embalagens apresentaram degradação diferenciada. Para a degradação em ambiente crítico do aterro, o cartão, tanto da embalagem de leite como do suco, foi primeiramente afetado (perda acentuada de resistência no primeiro mês, principalmente para a embalagem de leite, e perda de massa com 14 semanas), as camadas plásticas apresentaram alteração na cadeia polimérica com cinco semanas (para a de leite) e o alumínio revestido começou a evidenciar aspecto de degradação com três meses de imersão no chorume quando se apresentou descoberto. No ensaio de degradabilidade à intempéries, o cartão foi primeiramente afetado (perda acentuada de resistência no primeiro mês, principalmente para a embalagem de suco), as camadas plásticas externas apresentaram alteração na cadeia polimérica para ambas embalagens após o último período de exposição mas só foi removida da embalagem de leite no quinto mês, enquanto que na embalagem de suco isto não ocorreu. O alumínio, da embalagem de leite manteve-se revestido até o final do ensaio.

A perda de massa foi devida majoritariamente à degradação do cartão em ambos ensaios. O cartão duplex (da embalagem de leite) teve maior suscetibilidade a degradação que o cartão branco (da embalagem de suco), provavelmente, porque a lignina presente no cartão duplex seja removida na condição alcalina do ensaio de imersão no chorume e mais suscetível à ação do ultravioleta do que a celulose. Enquanto que o cartão branco seja, talvez, aditivado com resinas insolúveis que impeçam a ação do chorume e da água (chuvas). 
No ensaio de intemperismo natural verificou-se que a degradação das camadas poliméricas foram aceleradas pela ação dos efeitos das intempéries em conjunto e não somente pela radiação ultravioleta.

Para o ensaio de degradabilidade em ambiente crítico de aterro foi constatada a degradação das camadas poliméricas acelerada pelo meio (chorume) além do efeito da temperatura do ensaio. Não foi observada a desintegração visual dessa camada neste ensaio, apenas o início da quebra da cadeia polimérica a partir de cinco semanas e bastante acentuada ao final do ensaio. Neste ensaio foi possivel analisar comparativamente a velocidade de degradação destas camadas para cada tipo de embalagem a partir dos espectros obtidos no infravermelho. A camada externa da embalagem de leite apresentou bandas de degradação mais acentuadas que a de suco para o mesmo período, portanto a velocidade da quebra da cadeia polimérica da primeira é o muito maior que a embalagem de suco.

A Tabela 7.1 apresenta uma estimativa do tempo de vida destas embalagens na condição simulada ao aterro sanitário. A vida do cartão foi estimada com base nos resultados de perda de resistência à tração $(60 \%)$ obtidos para ambas as amostras. O tempo de degradação do alumínio foi estimado a partir dos resultados de perda de espessura, considerando-se a espessura original da folha de alumínio da embalagem exposta a partir do terceiro mês e a velocidade de corrosão da folha de alumínio da bisnaga de creme dental do estudo realizado no IPT, conforme relatado no item 3.3 do Capítulo 3. O tempo de início da alteração na estrutura química das camadas plásticas foi avaliado com base nos resultados de espectrofotometria no infravermelho. 
Tabela 7.1 - Estimativa da ordem de grandeza do tempo de permanência dos componentes das embalagens em ambiente crítico do aterro

\begin{tabular}{l|l|l|l}
\hline & $\begin{array}{l}\text { Amostra de embalagem de } \\
\text { leite }\end{array}$ & Amostra de embalagem de suco \\
\hline $\begin{array}{l}\text { Tempo estimado de } \\
\text { degradação do cartão }\end{array}$ & 1 mês & 6 meses \\
\hline $\begin{array}{l}\text { Tempo estimado de } \\
\text { degradação do aluminio }\end{array}$ & 1 ano e 5 meses & Não apresenta \\
\hline $\begin{array}{l}\text { Tempo estimado para o } \\
\text { início da degradação do }\end{array}$ & 1 mês & 6 meses \\
polietileno & & \\
\hline
\end{tabular}

A Tabela 7.2 apresenta uma estimativa do tempo de vida destas embalagens quando expostas às intempéries, efeitos encontrados nos lixões. O tempo de degradação do cartão foi obtido com base na vida média (para a embalagem de leite a vida média foi calculada pela expressão $6.4 \mathrm{da}$ curva de ajuste obtida no ensaio de resistência à tração e para a embalagem de suco a vida média foi estimada pela expressão 6.3 da curva de ajuste do ensaio de rigidez Lhomargy). O tempo de início da degradação das camada plástica externa da embalagem de suco foi verificado com base nos resultados de espectrofotometria no infravermelho após cinco meses de exposição às intempéries. Para a camada plástica externa da amostra de leite, o tempo de degradação foi relatado com base nos resultados de perda de massa ou remoção total.

Tabela 7.2 - Ordem de grandeza do tempo de permanência dos componentes das embalagens no ambiente expostos ao intemperismo natural

\begin{tabular}{l|l|l|l}
\hline & $\begin{array}{l}\text { Amostra de embalagem de } \\
\text { leite }\end{array}$ & Amostra de embalagem de suco \\
\hline $\begin{array}{l}\text { Tempo estimado de } \\
\text { degradação do cartão }\end{array}$ & 6 meses & 4,3 meses \\
\hline $\begin{array}{l}\text { Tempo estimado de } \\
\text { degradação do alumínio* }\end{array}$ & Não foi possível determinar & Não a presenta \\
\hline $\begin{array}{l}\text { Tempo estimado de início } \\
\text { degradação do polietileno } \\
\text { da camada extema }\end{array}$ & Não foi determinado & $\begin{array}{l}5 \text { meses (inicial - alteração na } \\
\text { estrutura química) }\end{array}$ \\
\hline $\begin{array}{l}\text { Tempo estimado de } \\
\text { completa degradação do do } \\
\text { polietileno da camada } \\
\text { externa }\end{array}$ & $\begin{array}{l}6 \text { meses (completa -remoção } \\
\text { total) }\end{array}$ & $\begin{array}{l}\text { Não foi constatada no período } \\
\text { de seis meses }\end{array}$ \\
\hline
\end{tabular}


Os resultados e metodologias obtidos neste trabalho, permitem que se extraia alternativas que podem minimizar o impacto ambiental gerado por este tipo de embalagem, por exemplo:

- utilizando-se as metodologias aqui apresentadas pode-se efetuar comparações entre embalagens, tanto as atuais com as de desenvolvimento, procurando assim obter uma melhor interação com o meio ambiente;

- escolha melhor de materiais e a redução na quantidade de material empregado nas estruturas, como a utilização de cartão não totalmente branqueado;

Recomenda-se:

- pesquisas sobre a viabilidade econômica de um prétratamento por imersão no chorume das embalagens descartadas para acelerar a degradação e diminuir o volume no aterro sanitário ou adotar a concepção de um aterro sanitário semi-aeróbico, conforme relatado na literatura;

- pesquisas para melhorar a suscetibilidade da ação das intempéries do cartão tipo duplex em menor tempo de ensaio através da exposição acelerada à radiação ultravioleta com condensação para favorecer a deterioração da embalagem no lixão.

Por outro lado e mesmo não sendo o objetivo principal deste trabalho, verificou-se também alguns aspectos que podem contribuir para a melhoria da qualidade da embalagem do tipo "Ionga vida":

- um tratamento térmico no cartão tipo duplex pode provocar melhoria das características de rigidez e por conseqüência resistência ao empilhamento, sendo conveniente que isto seja pesquisado;

- é possivel realizar alterações de projeto, mormente quanto ao formato da dobra na solda longitudinal, visando diminuir a penetração de 
umidade por estas áreas, aprimorando dessa forma, a propriedade asséptica deste tipo de embalagem.

Por fim, as embalagens, principalmente as descartáveis, devem ser projetadas para conter 0 produto adequadamente até a utilização e iniciarem a degradação o mais rápido possivel após o descarte seja em ambiente de aterro ou lixão, ou de outra forma permanecerem com seus componentes para a reciclagem. 


\section{REFERÊNCIAS BIBLIOGRÁFICAS}

ABREU,C.B. O futuro das embalagens. In: ENCONTRO NACIONAL DE GESTÃO EMPRESARIAL E MEIO AMBIENTE, São Paulo, 20-21 nov. 1995. Anais. São Paulo : EAESP - FGV / FEA - USP, 1995. p. 49-64 ALCAN ALUMÍNIO DO BRASIL S.A. DIVISÃO DE EMBALAGENS FLEXÍVEIS. Portfólio. Mauá : Alcan, 1997. 1v.

ALVES, R.M.V.; ARDITO,E.F.G. Embalagem cartonada asséptica: parâmetros de especificação e qualidade. In: VIALTA, A.; RODRIGUES, J.A.D.

(Coord.) Processos, instrumentação e automação de sistemas UHT.

Campinas: ITAL, 1996. p. 12.1-12.16.

ASSOCIAÇÃO BRASILEIRA TÉCNICA DE CELULOSE E PAPEL. Efluentes -

Determinação da demanda bioquímica de oxigênio. São Paulo, 1994.

6p. (ABTCP E5 1994)

ASSOCIAÇÃO BRASILEIRA TÉCNICA DE CELULOSE E PAPEL. Efluentes -

Determinação da demanda química de oxigênio. São Paulo, 1994. 5p. (ABTCP E9 1994)

ASSOCIAÇÃO BRASILEIRA TÉCNICA DE CELULOSE E PAPEL. Efluentes Determinação de pH. São Paulo, 1994. 3p. (ABTCP E10 1994) AMERICAN ASSOCIATION OF TEXTILE CHEMISTS AND COLORISTS AATCC Evaluation Procedure 7, Instrumental Assessment of the Change in Color of a Test Specimen. Washington (EUA), 1996. 2p. (AATCC Technical Manual) 
AMERICAN SOCIETY FOR TESTING AND MATERIALS. Standard Test Method for Resistance of Plastics to Chemical Reagents.

Philadelphia(EUA), 1987. 5p. (ASTM D543-87)

AMERICAN SOCIETY FOR TESTING AND MATERIALS. Standard Test

Method for Tensile Properties of Thin Plastics Sheeting.

Philadelphia(EUA), 1991. 9p. (ASTM D882-91)

AMERICAN SOCIETY FOR TESTING AND MATERIALS. Standard Test

Method for Determining Gas Permeability Characteristics of Plastic

Films and Sheetings. Philadelphia(EUA), 1982, reafirmada em 1992.

5p. (ASTM D1434-82)

AMERICAN SOCIETY FOR TESTING AND MATERIALS. Standard Test

Method for Rubber Property - Durometer Hardness. Philadelphia(EUA), 1991. 4p. (ASTM D2240-91).

AMERICAN SOCIETY FOR TESTING AND MATERIALS. Determining aerobic biodegradation of plastics materials in an actived-sludgewastewater-treatment system. Philadelphia: ASTM, 1993. 6 p. (ASTM D5271-93)

AMERICAN SOCIETY FOR TESTING AND MATERIALS. Determining aerobic biodegradation of plastic materials under controlled composting conditions. Philadelphia : ASTM, 1992. 6p. (ASTM D5338-92)

AMERICAN SOCIETY FOR TESTING AND MATERIALS. Determining the aerobic biodegradation of plastic materials in the presence of municipal sewer sludge. Philadelphia: ASTM, 1992. 4 p. (ASTM D5209-92)

AMERICAN SOCIETY FOR TESTING AND MATERIALS. Determining the aerobic biodegradability of degradable plastics by specific microorganisms. Philadelphia : ASTM, 1992. 4 p. (ASTM D5247-92) 
AMERICAN SOCIETY FOR TESTING AND MATERIALS. Determining the anaerobic biodegradation of plastic materials in the presence of municipal sewer sludge. Philadelphia : ASTM, 1992. 4 p. (ASTM D5210-92)

AMERICAN SOCIETY FOR TESTING AND MATERIALS. Determining water vapor transmission of materials.. Philadelphia: ASTM, 1994. $8 \mathrm{p}$. (ASTM E96-94)

AMERICAN SOCIETY FOR TESTING AND MATERIALS. Standard Practice for Operating Ligth- and Water-Exposure Apparatus (Fluorescent UVCondensation Type) for Exposure of Nonmetallic Materials. Philadelphia (EUA), 1991. 6p. (ASTM G53-91)

ARDITO, E.F.G., GARCIA, A.E. Título do artigo. Boletim Técnico do Centro de Tecnologia de Embalagem do Instituto de Tecnologia de Alimentos, v.1, n.5, p.1-9, set./out. 1989.

ASSOCIAÇÃO BRASILEIRA DE NORMAS TÉCNICAS. Papelão Ondulado Determinação da gramatura. Rio de Janeiro: ABNT, 1980. 3p. (MB 1321-80)

ASSOCIAÇÃO BRASILEIRA DE NORMAS TÉCNICAS. Materiais Metálicos Não Revestidos - Ensaio não acelerado de corrosão atmosférica. Rio de Janeiro : ABNT, 1986. 3 p. (NBR 6209-86)

ASSOCIAÇÃO BRASILEIRA DE NORMAS TÉCNICAS. Papelão Ondulado Determinação da capacidade de absorção de água. Rio de Janeiro : ABNT, 1980. 3 p. (NBR 6731-80)

ASSOCIAÇÃO BRASILEIRA DE NORMAS TÉCNICAS. Papel, cartão e papelão não absorventes : determinação da absorção de água (teste de Cobb). Rio de Janeiro: ABNT, 1982. 3 p. (NBR 7153 -82) ASSOCIAÇÃO BRASILEIRA DE NORMAS TÉCNICAS. Determinação da resistência à tração a úmido. Rio de Janeiro: ABNT, 1983. 3p. (NBR 7986-83) 
ASSOCIAÇÃO BRASILEIRA DE NORMAS TÉCNICAS. Procedimento Apresentação de projetos de aterros sanitários de resíduos sólidos urbanos. Rio de Janeiro: ABNT, 1984. 13p. (NBR 8419-84) ASSOCIAÇÃO BRASILEIRA DE NORMAS TÉCNICAS. Procedimento Apresentação de projetos de aterros controlados de resíduos sólidos urbanos.. Rio de Janeiro : ABNT, 1985. 9p. (NBR 8849-85) ASSOCIAÇÃO BRASILEIRA DE NORMAS TÉCNICAS. Degradação do solo - Terminologia.. Rio de Janeiro : ABNT, 1989. 45p. (NBR 10703-89) ASTALS, F. Relaciones fibra-agua. IApresentado ao Curso de Estruturas e Propriedades Mecânicas e Ópticas do Papel, UNESP, Botucatu, 19 e 20 ago. 1996/

BARROTTI, S.L.B. Tipos de papel. In: D'ALMEIDA, M.L.O. (Coord.)

Celulose e Papel: tecnologia de fabricação do papel. São Paulo : IPT/SENAI, 1988. cap.8, p.851.

BENVENUTO, C. Soluções de engenharia e a recuperação de lixões In: EVENTO DO PROGRAMA DE ATUALIZAÇÃO EM TECNOLOGIAS DE INTERESSE AMBIENTAL, 6, São Paulo, 1994. Anais. São Paulo: ABEQ/IPT/SABESP, 1994. p.94-106

BREMER, W.P. Films, polyethylene, low- and high-density. Packaging encyclopedia and yearbook, Denver, v.32, n.5, p.43-44, 1987.

BRISTON, J.H., KATAN, L.L. Plastics in contact with food. London : Food Trade, 1974. p. $239-445$

BUENO, F.S. Dicionário escolar da língua portuguesa. $11 \mathrm{ed}$. Rio de Janeiro: MEC/FENAME, 1980. 1263p.

BUTTLER, J.P. Título do artigo. Packaging encyclopedia and yearbook, Denver, v.30, n.4, p.72-79, 1985.

CABRAL, A.C.D. Polimeros sintéticos. In: (Coord.) Embalagens para produtos alimentícios. São Paulo: SICCT, s.d. p. 187-240 CABRAL, A.C.D. Laminados Flexiveis. In: (Coord.) Embalagens para produtos alimentícios. São Paulo : SICCT, s.d. p. 284-305 
CALDERONI, S. Os bilhões perdidos no lixo 2.ed. São Paulo: Humanitas I FFLCH USP, 1998. 345p.

CHAVES,R.; TANAKA,D.K.; WOLYNEC,S. Corrosão por pite de aço inoxidável ferrítico por água de rio. In: SEMINÁRIO NACIONAL DE CORROSÃO, 7 , Rio de Janeiro, 1980. Anais. Rio de Janeiro: Abraco, 1980. p. 74-83

CONSUMIDOR é quem dita, o. Packstar Embanews, São Paulo, p. 22-31, 1998.

CRESCIMENTO recorde das embalagens plásticas em 1994. Plásticos em

Revista, São Paulo, n.399, p.4-8, set. 1995.

D'ALESSIO, S.P. Aumenta a reciclagem de embalagens "longa vida" Celulose e Papel, n.62, p.27-29, 1998.

D'ALMEIDA, M.L.O. (Coord.) Estudo sobre o ensaio de rigidez em papéis e variantes. São Paulo, 1997. 46p. Monografia (estágio)-Agrupamento de Celulose e Papel/ Divisão de Produtos Florestais/ Instituto de Pesquisas Tecnológicas do Estado de São Paulo S. A.

D’ALMEIDA, M.L.O. (Coord.) Composição química dos materiais lignocelulósicos. In: D’ALMEIDA, M.L.O. (Coord.) Celulose e Papel: tecnologia de fabricação da pasta celulósica. São Paulo: IPT/SENAI, 1988. cap. 3, p.45-106.

DELTOMBE, E., VANLEUGENHAGHE,C. POURBAIX,M. Aluminium. In.: POURBAIX,M. Atlas of electrochemical equilibria in aqueous solutions. New York: NACE, 1974. 2 ed., p. 168-173

DIL CONSULTANTS IN DESIGN AND MARKETING COMUNICATION, RESEARCH INTERNATIONAL. Products and Packaging - the binomial of the future: 1st Research on Packaging. São Paulo, 1992. $12 \mathrm{p}$.

DISPARADA do leite longa vida, a. Parmalat em ação, s.I., n. 1, p.28-29 mai./jun. 1998.

DUSTON, T. E. How to measure the gains from recycling. Recycling Solid Waste, London, Quorum Books, 1993. p. 136. 
ERWIN,L., HEAERLY JR., L.H. Packaging and solid waste: management strategies. New York: AMA, 1990. $96 \mathrm{p}$.

FALKENSTEIN, G. Co-Extrusions Packaging encyclopedia and yearbook, Denver v. 32, n.5, p.36, 1987.

FONTANA, M.G. Eight forms of corrosion. In.: Corrosion Engineering. Singapore: McGraw-Hill, 1987. 3 ed., cap. 3, p. 63-70

GATENHOLM, P. Interfacial adhesion and dispersion in biobased composites. Molecular interactions between cellulose and other polymers IApresentado ao First International Symposium on Lignocellulosics-Plastics Composites, São Paulo, 13-15 março 1996/

GLADWIN, T.N.; KENNELY, J.J.; KRAUSE, T.S. Shifting paradigms for sustainable development: implications for management theory and research. Academy of Management Review, v.20, n.4, p.874-907, 1995.

GOMES, L. P.; POVINELLI, J.; VAZOLLER R. F. Biodegradação anaeróbica de celulose a partir de cultura bacteriana mista presente no chorume de depósito de lixo urbano a céu aberto. Estudos Tecnológicos, v.XXI, n.16, p. 43-48, 1998.

GRIFFIN,G.J.L. Degradation of polyethylene in compost burial. Journal of Polymer Science, Symposium, n. 57, 1976 . p. 281-286

HANLON, J.F. Handbook of package engineering. New York: McGraw-Hill, 1971. 1V.

HENESSY, B.J., MEAD, J.A., STENING, T.C. The permeability of plastic films. London: The Plastics Institute, 1967. p. 46-51

HUANG, E.A.; HUNKELLER, D.J. - LCA in Japan: Corporate Practices and Trends Relative to the Unided States, In Moving Ahead with ISO 14000, Philip A. Marcus \& John T. Willing, Editors, John Wiley \& Sons, Inc., 1997, pp. 253-266

INSTITUTO DE PESQUISAS TECNOLÓGICAS DO ESTADO DE SÃO PAULO. Tipos de reciclagem de embalagens laminadas. São Paulo, / 198 / 1V. 
INSTITUTO DE PESQUISAS TECNOLÓGICAS DO ESTADO DE SÃO PAULO. Divisão de Tecnologia de Transportes. Estudo comparativo da degradação de bisnagas para creme dental de alumínio e de material laminado multicamadas. São Paulo, 1993a. 31 p. (Relatório Técnico, 31.351)

INSTITUTO DE PESQUISAS TECNOLÓGICAS DO ESTADO DE SÃO PAULO. Divisão de Geologia. Medidas de temperatura no aterro sanitário Bandeirantes, Perus, SP. São Paulo, 1993b. 9p. (Relatório Técnico, 31.440)

JAPANESE INDUSTRIAL STANDARD. Plastics - Testing Method for Aerobic Biodegradability by Actived Sludge. JIS K 6950-94 : Tokio, 1994. $14 \mathrm{p}$.

JARDIM, N.S. (Coord.) Lixo municipal: Manual de gerenciamento integrado. São Paulo: Instituto de Pesquisas Tecnológicas do Estado de São Paulo: CEMPRE, 1995. 1 ed. Publicação IPT 2163.

KELEN, T. Polymer Degradation New York: Van Nostrand Reinhold Company Inc., 1983. 211p.

KLABIN FABRICADORA DE PAPEL E CELULOSE S.A. Klabin Boards:

Especificações Técnicas um cartão para cada uso. Portfólio. Telêmaco Borba Klabin, 1999. 1v.

KONING, J.W.; GODSHALL, W.D. Repeated recycling of corrugated containers and its effect on strength properties Tappi, v.58, n.9, p.146-150, Sep. 1975.

KUAN, G.S.S.; BENAZZI, R.C. Colagem superficial e revestimento. In: D'ALMEIDA, M.L.O. (Coord.) Celulose e Papel: tecnologia de fabricação do papel. São Paulo: IPT/SENAI, 1988. cap. 5, p.761-762.

KUDRJAWZEW, V. Reciclagem de PET - Visão do Reciclador. IApresentado no Ciclo de Debates " $A$ embalagem frente às questões ambientais" da Associação Brasileira de Embalagens, São Paulo, 14-15 out. 1998/

LEON, G.P. Reaproveitar é de lei. Pack, n. 16, p. 12-13, dez. 1998. 
MALUF, E. Elementos de Colorimetria Aplicada. Apresentado no Curso de Colorimetria do Laboratório Produtos Têxteis do Instituto de Pesquisas Tecnológicas do Estado de São Paulo, São Paulo, 13 e 14 dez. 1995/ MARQUES, M. Tetra Pak investe em reciclagem. Revista Gerenciamento Ambiental, n. 2, p. 40-41, Jun./Julho, 1998.

MODERN PLASTICS ENCYCLOPEDIA (ed.) Guide to plastics. New York: McGraw-Hill, 1970. 175 p.

MOURAD, A.N. Boletim Técnico do Centro de Tecnologia de Embalagem do Instituto de Tecnologia de Alimentos, Campinas, v. 8, n. 1, p. 5-6, jan./fev. 1996.

MÜLLER, J.S.; HAUBRICH, M.; HENCK, O.W. Avaliação da influência da taxa de radiação solar sobre a durabilidade de filmes agrícolas de PEBD. In:2 ${ }^{\circ}$ Congresso Brasileiro de Polímeros, São Paulo, 1993. Anais. São Paulo:ABPOL, 1993.p.288-291

NEDER, L.T.C. Reciclagem de resíduos sólidos de origem domiciliar: análise da implantação e da evolução de programas institucionais de coleta seletiva em alguns municípios brasileiros. In.: VEIGA, J.E. (org.) Ciência ambiental: primeiros mestrados. São Paulo: Annablume/FAPESP, 1998. p. $155-186$.

NEVES, F.L. Efeito da Interação entre fibras virgens e recicladas nas características físicas de cartões multifolhados. Piracicaba, 1996.

48p. Seminário (M.S.) - Escola Superior de Agricultura "Luiz de Queiroz", Universidade de São Paulo.

O'CONNOR, F.M. Chemical and Additives Modern Plastics Encyclopedia, v.64, n.10A, p.174, oct. 1987

OLIVEIRA, L.M., PADULA, M. Embalagens assépticas. In.: INSTITUTO DE TECNOLOGIA DE ALIMENTOS. Novas tecnologias de acondicionamento de alimentos. Campinas, 1988. p. 141-162 
PARRA, R. Uso da técnica de correntes de despolarização termicamente estimuladas para o controle da qualidade de filmes plásticos contendo aditivo anti-estático. São Paulo, 1995. 1v. Dissertação (M.S.) - Instituto de Física, Universidade de São Paulo.

PICHLER, E.F. (Coord.) Embalagem e acondicionamento para transporte e exportação: manual técnico. São Paulo: MIC/STI, SICCT, IPT, SENAI, 1984. 175p. (Publicação IPT no 1552)

PINHO, V.L. Reduzir, reutilizar e reciclar : de vilã do meio ambiente, a embalagem passou a ser parte importante da solução para o grande volume de lixo gerado. Pack, São Paulo, n. 8, p. 24-25, abr. 1998.

POTTS, J.E. Aspects of degradation and stabilization of polymers. In.: JELLINEK,H.H.G. (ed.) Biodegradation. Amsterdam: Elsevier, 1978. p. 618-657.

PROJETO de expansão. Packstar Embanews, São Paulo, p. 48-50, 1998.

QUANTO você sabe sobre embalagem e meio ambiente? F\&C Embalagem, São Paulo, n. 70, p. 42-44, jan. 1994.

RATHJE,W. Once and future landfills. National Geographic, 1992. p. 117135

REGENEX, L.L.C. / TETRA PAK BRAZIL. Aseptic packaging and polycoated secondary fiber recovery system. Kenner: Regenex, 1995. 31 p.

SADTLER RESEARCH LABORATORIES The infrared spectra atlas of monomers and polymers. Philadelphia, 1980. 269p.

SELF, R.W. Paper and paperboard Packaging encyclopedia and yearbook, Denver, v. 32, n. 5, p. 66-70, 1987.

SENHOR consumidor exige mais vida de prateleira, o Leite e Derivados, São Paulo, p.14-22, 1998. 
SHANABEL, W.. Polymer Degradation: Principles and practical applications. MünchenMien: Hanser, 1981. cap.7, p.197-210: Chemical Degradation

SIHTOLA, H.; FOGELBERG, B.C. The degradation of cellulose by ultraviolet light. Paper and Timber, n.11, p.430, 1954.

SWERN,D. Oxidation by atmospheric oxygen (autoxidation). In.: MARKLEY,C. (ed.) Fats and oils: fatty acids. Philadelphia: Interscience, 1961. 2 ed., p. 1387

TECHNICAL ASSOCIATION OF THE PULP AND PAPER INDUSTRY. Water absorptiveness of sized (non-bibulous) paper and paperboard (Coob test). TAPPI T441 om-84: Atlanta, 1984. $3 p$.

TECHNICAL ASSOCIATION OF THE PULP AND PAPER INDUSTRY. Water vapor transmission rate of paper and paperboard at high temperature and humidity. TAPPI T464 om-95 : Atlanta, 1995. 4 p.

TECHNICAL ASSOCIATION OF THE PULP AND PAPER INDUSTRY.

Stiffness of paperboard (Ressonance Lenght Method). TAPPI T $535 \mathrm{~cm}$ 85: Atlanta, 1984. 4p.

TECHNICAL ASSOCIATION OF THE PULP AND PAPER INDUSTRY. Water vapor transmission rate through plastic film and sheeting using a modulated infrared sensor. TAPPI T557 pm-95 : Atlanta, 1995. $6 \mathrm{p}$. TECHNICAL ASSOCIATION OF THE PULP AND PAPER INDUSTRY. Wax pick test of paperboard. TAPPI UM463-95: Atlanta, 1995. 1 p.

VAN V.; LAWRENCE H. Princípios de ciência dos materiais: materiais orgânicos e suas propriedades. Trad. de L. P. C. Ferrão. São Paulo: Edgard Blücher, 1970. 427p.

VIDELA, Héctor A. Corrosão microbiológica. São Paulo : Edgard Blücher, 1981. 65p. (Série Biotecnologia, v. 4) 
YAMBRACH,F.J., PENET,C. Redution of cellulose waste generated by paper packaging materials by the use of controlled enzimatic breakdown. In: IAPRI / WORLD CONFERENCE ON PACKAGING, 8, São Paulo, 20-23 jun. 1993. Proceedings. Campinas : CETEA, 1993. p. 882-888 